\title{
De jongens tegen de meisjes : een onderzoek naar verklaringen voor verschillen in studiesucces van jongens
}

Citation for published version (APA):

Belfi, B. E., Levels, M., \& van der Velden, R. K. W. (2015). De jongens tegen de meisjes : een onderzoek naar verklaringen voor verschillen in studiesucces van jongens. ROA. ROA Reports No. 005 https://doi.org/10.26481/umarep.2015005

Document status and date:

Published: 01/01/2015

DOI:

10.26481/umarep.2015005

Document Version:

Publisher's PDF, also known as Version of record

Please check the document version of this publication:

- A submitted manuscript is the version of the article upon submission and before peer-review. There can be important differences between the submitted version and the official published version of record.

People interested in the research are advised to contact the author for the final version of the publication, or visit the DOI to the publisher's website.

- The final author version and the galley proof are versions of the publication after peer review.

- The final published version features the final layout of the paper including the volume, issue and page numbers.

Link to publication

\footnotetext{
General rights rights.

- You may freely distribute the URL identifying the publication in the public portal. please follow below link for the End User Agreement:

www.umlib.nl/taverne-license

Take down policy

If you believe that this document breaches copyright please contact us at:

repository@maastrichtuniversity.nl

providing details and we will investigate your claim.
}

Copyright and moral rights for the publications made accessible in the public portal are retained by the authors and/or other copyright owners and it is a condition of accessing publications that users recognise and abide by the legal requirements associated with these

- Users may download and print one copy of any publication from the public portal for the purpose of private study or research.

- You may not further distribute the material or use it for any profit-making activity or commercial gain

If the publication is distributed under the terms of Article $25 \mathrm{fa}$ of the Dutch Copyright Act, indicated by the "Taverne" license above, 


\section{DE JONGENS TEGEN DE MEISJES}

Een onderzoek naar verklaringen voor verschillen in studiesucces van jongens

\section{Barbara Belfi, Mark Levels \& Rolf van der Velden (Red.)}

Met bijdragen van Barbara Belfia, Marloes de Hoon ${ }^{a}$, Jelle Jolles ${ }^{b}$, Frans Kaiserc, Judith Keizer ${ }^{\mathrm{b}}$, Renze Kolsterc, Mark Levelsa, Christoph Menga, Rolf van der Velden ${ }^{\mathrm{a}}$ en Hans Vossensteyn ${ }^{c}$

${ }^{a}$ Researchcentrum voor Onderwijs en Arbeidsmarkt, Universiteit Maastricht ${ }^{b}$ Centrum Brein \& Leren, Vrije Universiteit

' Center for Higher Education Policy Studies, Universiteit Twente 


\section{Colofon}

(c) Researchcentrum voor Onderwijs en Arbeidsmarkt (ROA). Niets uit deze uitgave mag op enige manier worden verveelvoudigd zonder voorafgaande schriftelijke toestemming van de directeur van het ROA.

\section{Contactpersonen:}

Prof. dr. Rolf van der Velden

Researchcentrum voor Onderwijs en Arbeidsmarkt

School of Business and Economics

Universiteit Maastricht

r.vandervelden@maastrichtuniversity.nl

Prof. dr. Jelle Jolles

Centrum Brein \& Leren

Faculteit der Gedrags- en Bewegingswetenschappen

Vrije Universiteit Amsterdam

j.jolles@vu.nl

Prof. dr. Hans Vossensteyn

Center for Higher Education Policy Studies

School of Management and Governance

Universiteit Twente

j.j.vossensteyn@utwente.nl

\section{Vormgeving}

ROA secretariaat, Maastricht

\section{Verkoop}

Researchcentrum voor Onderwijs en Arbeidsmarkt email: secretary-roa-sbe@maastrichtuniversity.nl website: www.roa.nl

ISBN: 978-90-5321-542-5 


\section{INHOUD}

01 Inleiding Barbara Belfi, Mark Levels en Rolf van der Velden (ROA)

1.1 Aanleiding en onderzoeksvraag 1

1.2 Uitwerking van de vraagstelling 2

1.3 Opzet van het onderzoek en leeswijzer 5

02 Genderverschillen in studiesucces: een literatuurstudie naar

verklarende mechanismen en contexten Frans Kaiser en Renze Kolster (CHEPS) 7

$\begin{array}{ll}\text { Samenvatting } & 7\end{array}$

2.1 Inleiding 8

2.2 Beelden van genderongelijkheid in studiesucces 9

2.3 Theoretische benaderingen bij het beschrijven en verklaren van
studie(keuze)gedrag

2.4 Mechanismen 13

2.4.1 Integratie van studenten (academisch en sociaal) 13

2.4.2 Inzet en cognitieve vaardigheden 18

2.4.3 Verwachtingen en preferenties over studie en arbeidsmarkt 20

2.4.4 Perceptie van kosten en baten van studeren 21

2.5 Discussie 23

03 Cognitief en non-cognitief presteren van jongens en meisjes in mbo en ho: Een neuropsychologisch perspectief Jelle Jolles en Judith Keizer (Centrum Brein \& Leren, $V U)$

Samenvatting $\quad 27$

$\begin{array}{ll}3.1 & \text { Inleiding } \\ & 3.1 .1\end{array}$

3.1.1 Het probleem 28

3.1.2 De overgang van voortgezet naar hoger onderwijs: een turbulente periode $\quad 29$

3.1.3 Doel, aanpak 30

3.1.4 Pretenties 31

3.2 Over de Adolescentie $\quad 32$

3.2.1 Begripsverheldering $\quad 32$

3.2.2 Kiezen en beslissen bij de laat-adolescent 33 
3.2.3 Zelfinzicht 34

3.2.4 Non-cognitieve vaardigheden 35

3.2.5 De laat-adolescent, het onderwijs en eerdere levenservaringen 36

3.2.6 De rol van de sociale achtergrond 37

3.2.7 Zelfregulatie als factor in studiesucces 38

3.3 Intermezzo: de hersen- en neuropsychologische ontwikkeling in

late adolescentie $\quad 38$

3.4 Over jongens-meisjes verschillen in de biopsychologische ontwikkeling 41

3.4.1 De ontwikkeling van verschillen tussen jongens en meisjes:

discussiepunten

3.4.2 Biologische verschillen in de hersenen en de invloed

van hormonen

3.4.3 Jongens-meisjes verschillen en leerstrategieën 43

3.4.4 Culturele en sociale invloeden 43

3.4.5 Gender stereotypes 44

3.4.6 Biopsychosociale interacties 45

3.4.7 Genderverschillen in psychologisch perspectief

3.5 Concluderende opmerkingen $\quad 45$

3.5.1 Multidimensioneel 46

3.56.2 Adolescentie: een 'age of opportunity' 47

3.5.3 Persoonlijke groei voor jongens versus meisjes 47

3.5.4 Individuele verschillen en de rol van de
persoonlijke levensgeschiedenis

3.5.5 Let op de groepsgemiddelden 49

3.5.6 Psychosociale factoren worden steeds belangrijker voor te maken keuzen

3.5.7 Wegnemen van stereotype bedreigingen 49

3.5.8 De belangrijke rol van de peer group 50

Appendix $3.1 \quad 53$

04 Leeromgeving en genderverschillen in studiesucces in het Nederlandse middelbaar beroepsonderwijs Mark Levels en Rolf van der Velden (ROA) 59

$\begin{array}{ll}\text { Samenvatting } & 59\end{array}$

4.1 Inleiding 60

$\begin{array}{lll}4.2 & \text { Data } & 61\end{array}$

$\begin{array}{lll}4.3 & \text { Analyse en resultaten } & 67\end{array}$

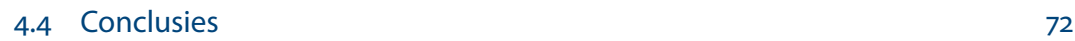

05 Leeromgeving en genderverschillen in studiesucces in het Nederlandse hoger onderwijs Christoph Meng (ROA) $\quad 75$

$\begin{array}{ll}\text { Samenvatting } & 75\end{array}$

$\begin{array}{lll}5.1 & \text { Inleiding } & 76\end{array}$

$\begin{array}{lll}5.2 & \text { Studiesucces: gemiddeld afstudeercijfer } & 79\end{array}$

$\begin{array}{ll}5.3 \text { Competenties } & 80\end{array}$ 
o6 Genderverschillen in cognitieve vaardigheden: cohort- of leeftijdseffecten Barbara Belfi, Mark Levels en Rolf van der Velden (ROA)

Samenvatting $\quad 85$

$\begin{array}{lll}6.1 & \text { Inleiding } & 86\end{array}$

6.2 Onderzoeksdoel en -vragen 88

6.3 Data en methoden $\quad 89$

6.4 Resultaten 90

6.4.1 Genderverschillen in cognitieve vaardigheden van Nederlandse jongvolwassenen met verschillende opleidingsniveaus 90

6.4.2 Genderverschillen in cognitieve vaardigheden van Nederlandse jongvolwassenen uit verschillende geboortecohorten, naar opleidingsniveau (op basis van PIAAC-data) 91

6.4.3 Wordt de trend bij laagopgeleide jong volwassenen verklaard door andere variabelen die samenhangen met leeftijdseffecten?

6.4.4 Cohortverschillen? Of leeftijdseffecten?

Bewijs van oudere cohorten

6.4.5 Cohortverschillen? Of leeftijdseffecten? 15-jarigen uit verschillende geboortecohorten vergeleken $\quad 100$

6.5 Discussie

07 Genderverschillen in studiesucces: Praktijkvoorbeelden van instellingen Renze Kolster en Hans Vossensteyn (CHEPS) Marloes de Hoon en

Mark Levels (ROA)

Samenvatting 103

$\begin{array}{lll}7.1 & \text { Inleiding } & 104\end{array}$

$\begin{array}{lll}\text { 7.1.1 Doel deelproject } & 104\end{array}$

$\begin{array}{lll}\text { 7.1.2 Onderzoeksvragen } & 105\end{array}$

7.1.3 Case selectie 106

7.2 Genderverschillen en studiesucces in Nederland 109

$\begin{array}{ll}\text { 7.2.1 Case studies: probleemperceptie } & 109\end{array}$

7.2.2 Gender-specifiek beleid studiesucces 112

7.3 Genderverschillen en studiesucces in het buitenland 120

$\begin{array}{ll}\text { 7.3.1 Probleemperceptie } & 120\end{array}$

7.3.2 Gender specifiek beleid studiesucces 123

$\begin{array}{ll}7.4 \text { Conclusie } & 124\end{array}$

08 Verschillen in studiesucces tussen jongens en meisjes in het mbo en ho:

conclusies, discussie en aanbevelingen Barbara Belfi, Mark Levels en

Rolf van der Velden (ROA), Jelle Jolles (Centrum Brein \& Leren, $V U$ ) 127

$\begin{array}{ll}8.1 & \text { Belangrijkste onderzoeksuitkomsten } \\ & 128\end{array}$ 
8.1.1 Verschillen in neuropsychologische- c.q. hersenfuncties en hersenontwikkeling die het studiesucces tussen jongens en meisjes in het mbo, hbo en wo kunnen verklaren

8.1.2 De relatie tussen in het mbo, hbo en wo veelvoorkomende leeromgevingen en het verschil in studiesucces tussen jongens en meisjes

8.1.3 Zijn er verschillen tussen mbo-, hbo- en wo-instellingen in de mate waarin studiesucces tussen jongens en meisjes verschilt en wat kunnen we leren van 'good practices'?

8.2 Aanbevelingen voor praktijk en beleid

8.3 Beperkingen van het huidige onderzoek en suggesties voor vervolgonderzoek 


\section{VOORWOORD}

In de afgelopen decennia hebben meisjes hun aanvankelijke achterstand in het onderwijs omgebogen in een voorsprong. Ze blijven minder vaak zitten, presteren beter en halen een hoger eindniveau. Er is al veel onderzoek verricht waarom meisjes beter presteren dan jongens, maar dat onderzoek richt zich vooral op het primair en secundair onderwijs. Ook in het postsecundair en tertiair onderwijs presteren meisjes echter beter, al is onduidelijk welke factoren hiervoor verantwoordelijk zijn.

Het Ministerie van OCW heeft - na een aanbesteding onder de raamcontractanten van OCW - het consortium bestaande uit ROA, VU en CHEPS opdracht gegeven om onderzoek te doen naar de oorzaken van verschillen in studiesucces tussen jongens en meisjes in het postsecundair en tertiair onderwijs. De onderzoeksvragen hebben betrekking op:

- het in kaart brengen welke verschillen in neuropsychologische- cq hersenfuncties en hersenontwikkeling leiden tot een verschil in studiesucces tussen jongens en meisjes;

- het analyseren of activerende leeromgevingen in het postsecundair en tertiair onderwijs deze verschillen vergroten;

- het in kaart brengen van de beleidsmaatregelen die instellingen treffen om deze verschillen te verkleinen.

Voorliggend rapport bevat de resultaten van dat onderzoek.

We bedanken de begeleidingscommissie van OCW bestaande uit Marjolein van der Klis, Ted Reininga, Lieke van Schouwenburg, Els Veenis en Bernard Verlaan, de klankbordgroep bestaande uit Joost Schaacke (DUO); Marianne Rensema (Onderwijsinspectie); Lex Herweijer (SCP); Mieke de Haan (MBO raad); Pierre Veelenturf (MBO raad); Johanna de Groot (VSNU); Nelet Kuipers (CBS), alsmede Prof. dr. Jaap Dronkers (Universiteit Maastricht) en Prof. dr. Mieke van Houtte (Universiteit Gent) voor hun commentaar op de opzet en eerdere versies van dit rapport.

Maastricht, 5 oktober 2015

Prof. dr. Rolf van der Velden

Directeur ROA en projectleider van het onderzoek 'De jongens tegen de meisjes' 


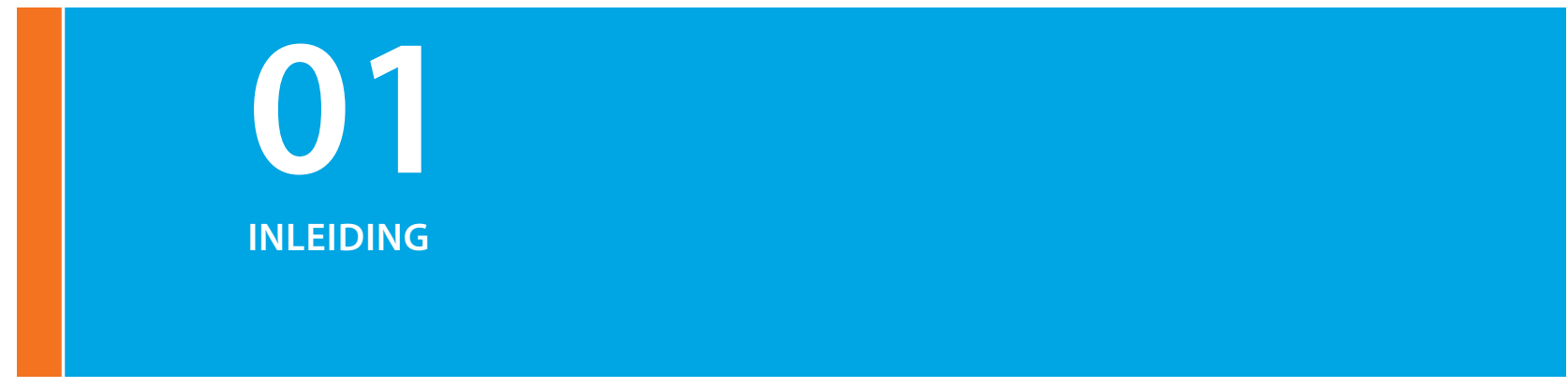

Barbara Belfi, Mark Levels en Rolf van der Velden (Researchcentrum voor Onderwijs en Arbeidsmarkt)

\subsection{Aanleiding en onderzoeksvraag}

In het primair en secundair onderwijs behalen meisjes betere leerprestaties dan jongens (Van Langen en Driessen 2006; Driessen en Van Langen, 2011). Ook in het postsecundair en tertiair onderwijs blijven de rendementen van jongens achter bij die van meisjes. Beschrijvend onderzoek naar de wijze waarop de leerprestaties van jongens zich verhouden tot die van meisjes in het postsecundair (mbo) en tertiair ( $\mathrm{hbo}$, wo) onderwijs wijst op drie belangrijke regelmatigheden. Ten eerste blijken jongens in het postsecundair en tertiair onderwijs slechter te presteren dan meisjes. Ze vallen vaker uit, stromen vaker af, en doen er langer over om een diploma te halen (Schaacke, 2014). Daarnaast blijkt de mate waarin studiesucces verschilt tussen jongens en meisjes deels afhankelijk van de sociaaleconomische en etnische herkomst. Zo zijn de verschillen in studiesucces tussen jongens en meisjes doorgaans groter naarmate ze afkomstig zijn uit een lager sociaal milieu of van een niet-westerse herkomst. Ten slotte lijkt het er op dat meisjes niet in staat zijn hun relatieve voorsprong in studiesucces te vertalen naar een succesvolle transitie op de arbeidsmarkt. Ze bekleden minder vaak hoge functies, verdienen minder salaris en zijn vaker werkloos (Kuipers, 2014).

In het maatschappelijke debat wordt een aantal oorzaken van de achterstand in studiesucces van jongens geopperd, maar de geldigheid van deze verklaringen is nog steeds onderwerp van discussie. Er is weliswaar veel empirisch onderzoek gedaan naar de verschillen in studiesucces tussen jongens en meisjes in het primair en secundair onderwijs, maar het is de vraag of deze bevindingen zonder meer toepasbaar zijn op de verschillen in studiesucces tussen jongens en meisjes in het postsecundair en tertiair onderwijs. Hoewel in het postsecundair en tertiair onderwijs veel onderzoek is verricht naar algemene factoren die studiesucces verklaren', is dit zelden beschreven vanuit het sekseperspectief. Een mogelijk relevante nieuwe ontwikkeling is bovendien dat er in het

$1 \quad$ Zowel algemene studies (Kottmann en Kaiser, 2013), als specifieke studies bijvoorbeeld naar de rol van het bindend studieadvies BSA (Arnold, 2014), het probleem gestuurd onderwijs PGO (Thomas, 2012) en het leenstelsel (Vossensteyn et al., 2013; Aamodt et al., 2009). 
laatste decennium kennis en inzichten verkregen zijn die wijzen op de mogelijkheid dat verschillen in non-cognitieve vaardigheden een rol kunnen spelen in de verklaring van verschillen in studiesucces tussen jongens en meisjes. Dergelijke vaardigheden berusten mede op de hersenfuncties.

Het ontbreekt vooralsnog aan een wetenschappelijk gefundeerde overzichtsstudie, waarin de verschillende bevindingen in context besproken worden en nadrukkelijk gerelateerd worden aan verschillen tussen jongens en meisjes en de mate waarin deze verschillen samenhangen met sociale en etnische herkomst. Om die reden heeft Ministerie van OCW een aanbesteding uitgeschreven voor een onderzoek naar de oorzaken van de verschillen in studiesucces van jongens en meisjes in het postsecundair en het tertiair onderwijs. Het consortium bestaande uit het ROA (UM), CHEPS (UT) en het Centrum voor Brein en Leren (VU), heeft in competitie de opdracht verworven. De doelstellingen van dat onderzoek zijn (1) onderzoeken wat de oorzaken zijn van de verschillen in studiesucces tussen jongens en meisjes in het postsecundair en tertiair onderwijs, en (2) inventariseren welke maatregelen de overheid dan wel de onderwijsinstellingen zouden kunnen aanwenden om de verschillen in studiesucces tussen jongens en meisjes te verkleinen.

Het voorliggende rapport is het verslag van dat onderzoek.

\subsection{Uitwerking van de vraagstelling}

Zoals uit de vorige paragraaf duidelijk is geworden, is tot op heden nog weinig onderzoek verricht naar de vraag waarom meisjes het in het postsecundair en tertiair onderwijs beter doen dan jongens. In onderzoek naar de prestatieverschillen tussen jongen en meisjes in het primair en het secundair onderwijs, worden geslachtsverschillen in studiesucces doorgaans vanuit twee invalshoeken verklaard: (1) de biologisch-genetische invalshoek en (2) de sociaal-culturele invalshoek. Bij het eerste perspectief ligt het accent vooral op morfologische verschillen tussen de hersenen van jongens en meisjes (o.a. Buchman et al., 2008; James, 2007). Bij het tweede perspectief ligt het accent vooral op omgevingsfactoren, zoals de invloed van de gezinssituatie, het gedrag van ouders, het gedrag van docenten en de invloed van de schoolomgeving (o.a. Buchman et al., 2008; Auduc, 2009).

Beide typen verklaringen zijn in zekere zin onbevredigend, omdat ze onvoldoende in staat zijn om te kunnen verklaren waarom de aanvankelijke achterstand van meisjes in een voorsprong is omgeslagen. ${ }^{2}$ We moeten daarom op zoek naar verklaringen die erop gericht zijn juist deze verandering te verklaren. Eén van die verklaringen die in lijn ligt met het sociaal-cultureel perspectief betreft de feminisering van het onderwijs. De oververtegenwoordiging van vrouwen in docententeams, met name in het primair onder-

2 Illustratief hiervoor is dat dezelfde typen verklaring in de jaren ' 70 en ' 80 gebruikt werden om de achterstand van meisjes ten opzichte van jongens te verklaren. 
wijs, zou nadelig zijn voor de onderwijsprestaties van jongens. Echter, tot op heden is er geen afdoende bewijs gevonden dat dit de voorsprong van meisjes in het primair en secundair onderwijs zou verklaren (Driessen \& Doesborgh, 2004; Martino, 2008) en het is onwaarschijnlijk dat dit de veranderde prestaties in het postsecundair en tertiair onderwijs zou kunnen verklaren, aangezien daar nauwelijks sprake is van feminisering.

Een andere verklaring is gelegen in de veranderingen in het curriculum. De wijze waarop het onderwijsaanbod is vormgegeven zou nadelig zijn voor jongens (Claessen, 2013). Er wordt in curricula steeds meer aandacht besteed aan taal en ook het reken- en wiskundeonderwijs zou 'taliger' worden. Daarnaast spelen communicatieve vaardigheden als het schrijven van werkstukken en het geven van presentaties een steeds grotere rol in het onderwijs. Vooral meisjes zouden hier voordeel van hebben aangezien zij meer gebruik zouden maken van verbaal-linguïstische leerstrategieën dan jongens. Jongens op hun beurt zouden weer meer gebruik maken van visueel ruimtelijke leerstrategieën die vooral van pas komen bij het oplossen van rekenkundige problemen. Ook samenwerkingsvaardigheden zijn steeds belangrijker geworden binnen het onderwijs. Werkstukken worden in teamverband gemaakt en dat vergt overleg en afstemming. Ook van deze verandering zouden meisjes meer profijt hebben dan jongens. Zo heeft onderzoek van Jolles en collega's reeds aangetoond dat meisjes vaardiger zijn dan jongens in non-cognitieve functies die voor sociale interacties van belang zijn als zelfinzicht, zelfregulatie, impulsbeheersing, plannen \& prioritering en inzicht in de intenties en emoties van anderen (Jolles, 2007; 2009, Veroude et al., 2013; Woelders et al., 2014).

In het primair en secundair onderwijs zijn deze veranderingen in leeromgeving deels geleidelijk, deels versneld ingevoerd. Zo is door de invoering van het Studiehuis in het havo en vwo veel meer nadruk komen te liggen op sociale interacties. Een dergelijke onderwijshervorming leent zich goed om te kijken naar de effecten daarvan op de prestaties van jongens en meisjes. Onderzoek van het ROA laat zien dat de invoering van het Studiehuis inderdaad voordeliger is geweest voor meisjes dan voor jongens (Coenen, Meng en Van der Velden, 2011).

Dit sluit aan bij het groeiende besef dat de verschillen in onderwijsprestaties tussen jongens en meisjes niet zozeer begrepen dienen te worden vanuit hetzij het biologischgenetische verklaringsperspectief hetzij het sociaal-cultureel verklaringsperspectief, maar juist vanuit de combinatie van deze perspectieven, die uitgaat van een mismatch tussen de neuropsychologische ontwikkeling en de leeromgeving (Jolles, 2007; Luken, 2008). Deze mismatch zou met name in het postsecundair en tertiair onderwijs tot uiting komen omdat deze veelal gekarakteriseerd wordt door onderwijspraktijken waarvoor met name het laat-adolescente jongensbrein vaak nog niet is toegerust. In het bijzonder gaat het hier om vormen van onderwijs waarin de leerling een fors aandeel heeft in het plannen, het anticiperen en het betrokken zijn bij een lange-termijn perspectief (Jolles, 2007). Vrijwel alle vormen van het huidige postsecundair en tertiair onderwijs worden gekenmerkt door zelfgestuurd leren, waarbij de student een actieve rol in het leerproces aanneemt, en waarbij de docent eerder optreedt als coach of begeleider dan als centrale 
informatieoverdrager. In dergelijke 'activerende leeromgevingen' - ook wel krachtige leeromgevingen genoemd - spelen onderwijsactiviteiten als zelfstandig leren, vraaggestuurd leren, samenwerken in groepen en leren op de werkvloer een belangrijke rol. Voorbeelden van activerende leeromgevingen zijn het competentiegericht onderwijs in het mbo en hbo en het projectgericht/probleemgestuurd onderwijs in het wo.

In dit rapport gaan we uit van een model waarin de interactie tussen hersenontwikkeling en non-cognitieve vaardigheden enerzijds en de leeromgeving anderzijds centraal staat bij de verklaring van het verschil in studiesucces tussen jongens en meisjes in het postsecundair en tertiair onderwijs. Daarom zal een belangrijk deel van het onderzoek gericht zijn op het achterhalen van de effecten van de invoering van activerende leeromgevingen in het mbo en ho op de prestaties van jongens en meisjes. Daarbij zullen we ook - waar mogelijk en relevant - nagaan of die prestatieverschillen variëren tussen leerlingen uit verschillende sociaaleconomische milieus en etnische herkomst. De aansluiting met de arbeidsmarkt komt zijdelings aan de orde. Figuur 1 geeft het algemene verklaringsmodel weer.

FIGUUR 1.1 Overzicht van verklaringsmodel verschillen in studiesucces jongens en meisjes

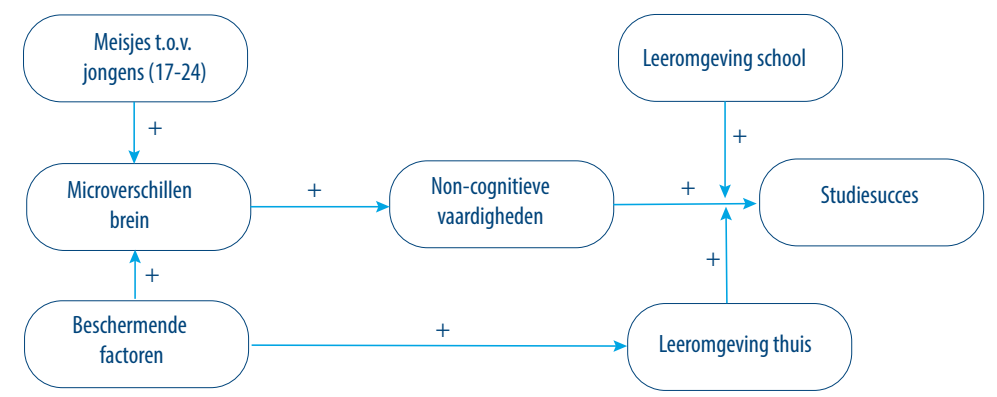

Noot. In dit verklaringsmodel wordt onder de leeromgeving van de school o.a. verstaan: de competentie-gerichtheid van het curriculum, de mate van vereiste zelfstandigheid, het gezag van de leerkrachten en de homogeniteit van de groep. Onder microverschillen in het brein worden zowel verschillen in hersenstructuur als hersenontwikkeling verstaan. Beschermende factoren zijn o.a. een hoge sociaaleconomische en autochtone afkomst. Non-cognitieve vaardigheden zijn o.a.: zelfregulering, zelfinzicht, planvermogen en samenwerkingsvaardigheden. Onder de leeromgeving thuis wordt o.a. de voorbeeldfunctie en het gezag van de ouders verstaan. Tot slot wordt studiesucces in dit model geoperationaliseerd als prestaties, rendementen (uitval, diplomabezit) en competenties.

\section{De onderzoeksvragen zijn:}

1. Welke verschillen in neuropsychologische- c.q. hersenfuncties en hersenontwikkeling kunnen verschillen in studiesucces tussen jongens en meisjes in het mbo, hbo en wo verklaren?

2. Welke relatie bestaat er tussen in het mbo, hbo en wo veelvoorkomende leeromgevingen en het verschil in studiesucces tussen jongens en meisjes? 
3. Zijn er verschillen tussen mbo-, hbo- en wo-instellingen in de mate waarin studiesucces tussen jongens en meisjes verschilt en wat kunnen we leren van 'good practices'?

\subsection{Opzet van het onderzoek en leeswijzer}

De onderzoeksvragen worden in een 6-tal deelonderzoeken beantwoord.

Op de eerste plaats is door CHEPS een uitgebreid literatuuronderzoek verricht naar welke specifieke interventies in het postsecundair en tertiair onderwijs effect hebben op studiesucces in het algemeen en in hoeverre daarbij verschillen optreden tussen jongens en meisjes. Daarbij wordt een model gehanteerd waarin een onderscheid wordt gemaakt tussen Contexten (leeromgeving, achtergronden van studenten) en Mechanismen (verwachtingen en preferenties over studie en arbeidsmarkt; socialisatie van studenten; inzet en vaardigheden van studenten; gepercipieerde kosten en baten van studeren). De resultaten van deze literatuurstudie worden beschreven in Hoofdstuk 2.

Door het Centrum voor Brein \& Leren is een literatuurstudie verricht naar de ontwikkeling van de laat-adolescent en de samenhang tussen intrinsieke rijping van het brein en de cognitieve en non-cognitieve processen die studiesucces beïnvloeden, alsmede naar de invloed van sociale omgeving op deze relatie. Dit deelonderzoek beoogt de verschillen in hersenontwikkeling in kaart te brengen en deze verschillen te relateren aan cognitieve en non-cognitieve functies die voor het leerproces relevant zijn. Daarnaast worden ook leerling/studentfactoren zoals aard van de (sociaal-culturele) achtergrond, schoolen leerervaring, en verwante factoren mee in beschouwing genomen. De resultaten van deze literatuurstudie worden beschreven in Hoofdstuk 3.

Daarna volgt een aantal empirische hoofdstukken op basis van bestaande data, waarbij door het ROA is nagegaan wat de effecten zijn van activerende leeromgevingen in het mbo en ho op de prestaties van jongens en meisjes en of we de voorsprong van meisjes ook waarnemen als we kijken naar de competenties. Eerst wordt in Hoofdstuk 4 gekeken naar de gevolgen van de invoering van competentiegericht onderwijs (CGO) in het mbo voor de prestaties van jongens en meisjes met verschillende sociaaleconomische en etnische achtergronden. Hiervoor gebruiken we registerdata van Centraal Register Beroepsopleidingen (CREBO) en Dienst Uitvoering Onderwijs (DUO). De uitkomstmaat is of binnen de nominale studieduur een diploma is behaald, of men nog op de opleiding zit of dat men de opleiding voortijdig verlaten heeft.

Vervolgens wordt in Hoofdstuk 5 onderzocht wat het verband is tussen activerende leeromgevingen in het tertiair onderwijs en de studieprestaties. Dit gebeurt op basis van een secundaire analyse van de zogenaamde REFLEX data, een internationaal onderzoek onder afgestudeerden van het ho. De centrale vraag is of verschillende leeromgevingen 
verschillend uitwerken op het studiesucces voor jongens en meisjes. Studiesucces wordt daarbij gedefinieerd aan de hand van het gemiddelde afstudeercijfer en aan de hand van het type en niveau van competenties die de afgestudeerden 5 jaar na behalen van het diploma bezitten.

In Hoofdstuk 6 kijken we naar de ontwikkeling van kernvaardigheden over de schoolloopbaan. We kijken naar de ontwikkeling en verschillen in cognitieve vaardigheden tussen jongens en meisjes op 15-jarige leeftijd op basis van de PISA-data. Daarna kijken we of we deze verschillen ook terugvinden wanneer we kijken naar jongvolwassenen. Dit gebeurt op basis van de drie adult literacy surveys die in Nederland gehouden zijn, IALS, ALL en PIAAC. We proberen daarbij leeftijd- en cohorteffecten zo goed mogelijk te scheiden.

Ten slotte zal in Hoofdstuk 7 verslag worden gedaan van een aantal case studies. Hierbij staat de vraag centraal of en zo ja hoe onderwijsinstellingen in het mbo, hbo en wo erin slagen om de verschillende behoeften van jongens en meisjes te vertalen in een kleinere kloof. Zijn er 'good practices' van instellingen waarbij actief geprobeerd wordt om de achterstand van jongens te verkleinen?

In Hoofdstuk 8 volgen de conclusies en samenvatting van het onderzoek. 


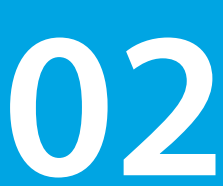

\section{GENDERVERSCHILLEN IN STUDIESUCCES: EEN LITERATUURSTUDIE NAAR VERKLARENDE MECHANISMEN EN CONTEXTEN}

\section{Frans Kaiser en Renze Kolster \\ (CHEPS)}

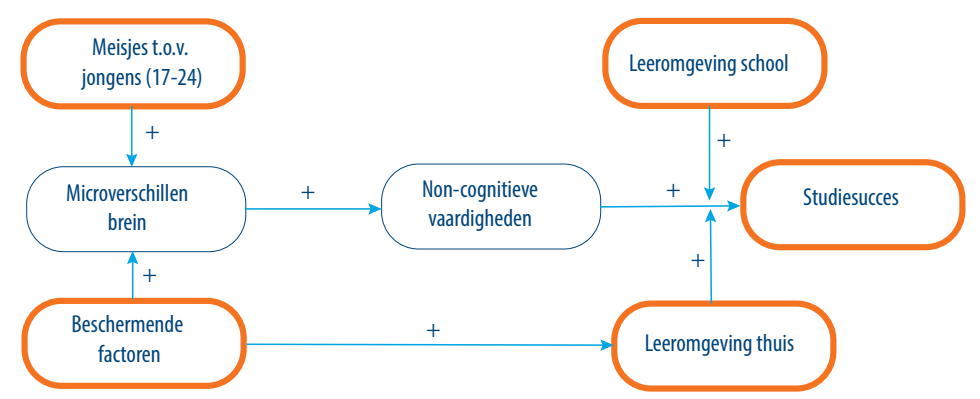

\section{Samenvatting}

In dit hoofdstuk wordt verslag gedaan van een literatuurstudie naar mogelijke verklaringen voor verschillen in studiesucces in het hoger onderwijs en middelbaar beroepsonderwijs tussen jongens en meisjes (gender gap) en de rol die vier mechanismen (mate waarin studenten zijn geïntegreerd of gesocialiseerd binnen een studie, de inzet en vaardigheden van studenten, de verwachtingen en preferenties van studenten ten aanzien van opleiding en de arbeidsmarkt en tenslotte de kosten en baten die aan studeren verbonden zijn) daarbij spelen. Van de vier mechanismen krijgt sociale integratie en betrokkenheid de meeste aandacht. Beleidsinstrumenten die inzetten op het vergroten van de integratie en betrokkenheid lijken het effectiefst in het vergroten van het studiesucces. Studentgerichte onderwijsvormen, die een grote inzet vragen zijn vooral voor meisjes effectief; voor jongens sluiten deze maatregelen minder goed aan bij hun genderbeeld en (non-cognitieve) vaardigheden, hetgeen een negatieve invloed op hun prestaties heeft. Ten aanzien van de verwachtingen en preferenties van opleiding en arbeidsmarkt zijn geen aanwijzingen voor genderspecifieke invloeden aangetroffen. 
Ook de algemene beleidsinterventies die op dit gebied zijn ontwikkeld (vooral voorlichting en begeleiding) zijn vrijwel niet op jongens en slechts beperkt op meisjes gericht (techniek). Uit de literatuur over de gepercipieerde baten en lasten komt naar voren dat het (gepercipieerde) saldo van baten en lasten voor vrouwen lager is dan mannen, maar dat er enkele sociaal psychologische mechanismen zijn waardoor vrouwen ondanks die lage baten toch beter presteren. Het ontbreken van een financieel instrumentarium om het genderverschil in studiesucces te overbruggen is dan ook geen verrassing.

\subsection{Inleiding}

Studiesucces is een belangrijk thema in de (inter)nationale beleids- en onderzoeksliteratuur. Nu de massificatie van het hoger onderwijs in de meeste Westerse landen is 'voltooid' richt de aandacht van de beleidsmakers zich meer op het studiesucces. Mede doordat er veel studenten uit niet-traditionele groepen komen is het niet meer vanzelfsprekend dat de oude onderwijsmodellen nog steeds voldoende effectief zijn. Aandacht voor de effectiviteit van het (hoger) onderwijsstelsel is niet alleen van belang voor de verdere ontwikkeling van de kennissamenleving, maar ook met het oog op sociale cohesie en verschillen in rendement tussen groepen. Bij dat laatste is de aandacht voor een belangrijk deel gericht op niet-traditionele deelnemers (uit sociaal economische achterstandsgroepen en etnische achterstandsgroepen), maar ook op het verschil in prestaties tussen jongens en meisjes. Hoe het genderverschil is te verklaren en wat er aan te doen is, zijn vragen die in de (inter)nationale onderzoeks- en beleidsliteratuur aandacht hebben gekregen. In dit hoofdstuk gaan we in die literatuur op zoek naar de factoren die studiesucces in het hoger onderwijs en middelbaar beroepsonderwijs bepalen. Daarbij zal specifieke aandacht zijn voor de verschillen in studiesucces tussen jongens en meisjes en werken we uit via welke mechanismen verschillen tussen jong adolescente jongens en meisjes doorwerken in andere factoren, waarvan we weten dat ze bepalend zijn voor studiesucces. Naast de uitwerking van mechanismen rapporteren we over bevindingen uit studies naar contextfactoren die de leeromgeving bepalen, en die theoretisch van belang worden geacht voor verschillen tussen jongens en meisjes. Zo ontstaat een - op literatuur gebaseerd - overzicht van mogelijke verklaringen van studiesucces verschillen tussen jongens en meisjes.

Wij bestuderen de volgende groepen van contextfactoren: leeromgevingen (met aandacht voor structurele aspecten van het onderwijs) en achtergronden van studenten. We bestuderen ook een viertal mechanismen, die samenhangen met de mate waarin studenten zijn geïntegreerd of gesocialiseerd binnen een studie, de inzet en vaardigheden van studenten, de verwachtingen en preferenties van studenten ten aanzien van opleiding en de arbeidsmarkt en tenslotte de kosten en baten die aan studeren verbonden zijn. Maar eerst besteden we kort aandacht aan de stand van zaken ten aanzien van genderongelijkheid in studiesucces. 
In de zoektocht naar relevante onderzoeken is in eerste instantie gebruik gemaakt van een aantal overzichtsartikelen waarin de grote lijnen worden geschetst. Deze artikelen zijn vervolgens als startpunt gebruikt voor het identificeren van andere relevante publicaties en voor het opsporen van nieuwe publicaties via zoektochten in Web of Science en Google Scholar. In het overzicht ligt de nadruk op het hoger onderwijs, maar er is ook aandacht besteed aan literatuur waarin het mbo aan bod komt.

\subsection{Beelden van genderongelijkheid in studiesucces}

In tal van publicaties wordt geconstateerd dat genderongelijkheid in studiesucces in het (hoger) onderwijs weer toeneemt, nu in het nadeel van jongens. Studiesucces in brede zin kent drie aspecten: toegang tot hoger onderwijs, studiesucces in enge zin (uitval, rendement, prestaties) en positie op de arbeidsmarkt. Genderverschillen en het jongensprobleem komen in verschillende mate bij deze drie aspecten naar voren en ook verklaringen die voor de genderverschillen te berde worden gebracht zijn niet identiek voor deze drie aspecten (Jacobs, 1996).

Tegen het eind van de vorige eeuw bleek er in de literatuur beperkt aandacht te zijn voor de invloed van gender op toegang en studiesucces in het hoger onderwijs. Gender werd als een interveniërende variabele gezien bij de twee andere, grote verklaringen: sociaaleconomische status en etniciteit. Meisjes hadden een achterstand, die in Nederland mede door beleid als 'Een slimme meid is op haar toekomst voorbereid' en aandacht voor verschil in behandeling van meisjes en jongens op school is ingelopen ${ }^{3}$ (Ministerie van Onderwijs Cultuur en Wetenschappen, 1998). Na de eeuwwisseling is de factor gender echter op de agenda gestegen, waarbij niet zozeer de achterstand van meisjes, maar de achterstand van jongens centraal is komen te staan. Daarbij gaat het dan vooral over toegang tot hoger onderwijs en studiesucces in enge zin. Bij de positie op de arbeidsmarkt is er nog steeds sprake van een achterstand van meisjes ten opzichte van jongens (Kuipers, 2014).

In een aantal Nederlandse onderzoeken is aangegeven dat jongens op achterstand staan in het onderwijs. Bijna tien jaar geleden hebben Van Langen en Driessen over de situatie in het hoger onderwijs al gerapporteerd en meer recent hebben Severiens en ten Dam (2012), Claessen (2013) en Schaacke (2014) de constatering nogmaals bevestigd. Ook in het mbo zijn er tal van rapporten die het verschil in studiesucces naar voren halen (Elffers, 2011; Herweijer, 2008; Kenniscentrum Beroepsonderwijs Arbeidsmarkt, 2014; Kennisnet, 2013; Onderwijsinspectie, 2014; Platform Beleidsinformatie, 2014).

Internationaal is zowel door onderzoekers als op beleidsniveau de aandacht gevestigd op het feit dat het verschil in prestaties tussen jongens en meisjes (het gender gap) is

3 De invloed van deze beleidsinstrumenten is ingebed in bredere maatschappelijke ontwikkelingen zoals de ontwikkeling van de welvaartstaat, sociaal- en politiek-culturele ontwikkelingen sinds eind jaren zestig, de opkomst van de verzorgingsstaat waardoor de structuur van de arbeidsmarkt sterk is veranderd. 
gegroeid (Evers et al., 2006; Jorgensen et al., 2009; OECD, 2008). In een recent artikel wordt dat beeld nog eens onderstreept (The Economist, 2015). Dat dit verschijnsel niet beperkt is tot het hoger onderwijs maar zich ook op mbo niveau voordoet wordt onder andere door Olsen en Jørgensen aangegeven (Jørgensen, 2015; Olsen et al., 2014).

\subsection{Theoretische benaderingen bij het beschrijven en verklaren van studie(keuze) gedrag}

In deze paragraaf beschrijven we in het kort de meest gangbare theoretische benaderingen bij het beschrijven en verklaren van studie(keuze)gedrag. Vervolgens geven we aan hoe de vier mechanismes 'integratie van studenten', 'inzet en cognitieve vaardigheden', 'verwachtingen en preferenties van studie en arbeidsmarktpositie' en 'gepercipieerde baten en lasten' zijn ingebed in die theoretische benaderingen en hoe de factor gender daarin wordt meegenomen.

De meeste verklaringen voor studiesucces zijn op een of andere manier schatplichtig aan het integratiemodel van Tinto. Tinto ziet de mate waarin een student is geïntegreerd in een hoger onderwijsinstelling als cruciaal voor studiesucces. Hoe meer een student in de academische en sociale gemeenschap is opgenomen, hoe kleiner de kans dat hij of zij vroegtijdig de opleiding of instelling verlaat. Betrokkenheid (bij de eigen doelstellingen/aspiraties en bij de doelstellingen van de instelling) zorgt voor meer integratie en vice versa. Academische prestaties versterken de academische integratie en interacties met gelijkgestemden, klas-/studiegenoten en docenten versterken de sociale integratie.

FIGUUR 2.1 Een conceptueel kader voor uitval uit hoger onderwijs

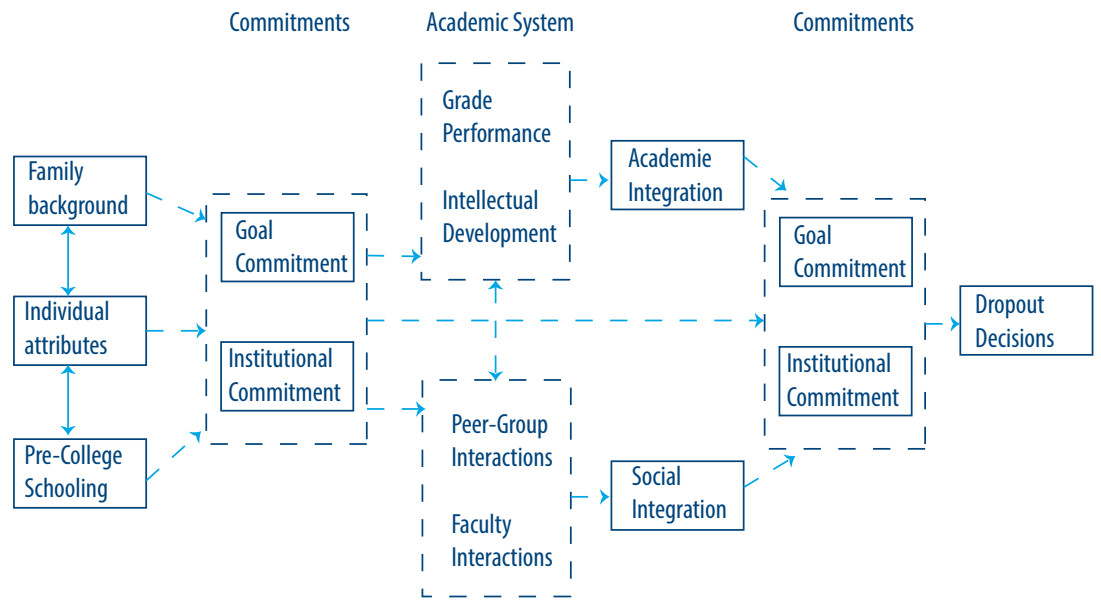

Bron: (Tinto 1998) 
Betrokkenheid ('engagement') treffen we ook aan in de literatuur die veel in onderzoek naar studiesucces in primair en secundair onderwijs wordt gebruikt (Fredricks et al., 2004). In deze literatuur, die op punten een duidelijke overlap heeft met de benadering van Tinto, wordt betrokkenheid uiteengerafeld in 'behavioral engagement' (de student laat in zijn/haar gedrag zien betrokken te zijn bij het onderwijs en de onderwijsinstelling: student gaat naar alle lessen, werkt mee aan alle opdrachten, vertoont geen afwijkend/verstorend gedrag, neemt deel aan school gerelateerde activiteiten), 'emotional engagement' (de student voelt zich betrokken bij onderwijs, klas en onderwijsinstelling en voelt zich daar thuis) en 'cognitive engagement' (de student investeert in zijn of haar leren, heeft een duidelijke intrinsieke motivatie). Een grotere betrokkenheid leidt tot betere studieresultaten en vooral tot minder uitval. De initiële betrokkenheid en mate waarin de betrokkenheid tot integratie kan leiden wordt beïnvloed door achtergrondkenmerken van de student (zoals de familie-achtergrond, individuele kenmerken en schoolresultaten/vooropleiding). In deze literatuur is ook aandacht voor de mate waarin en de wijze waarop de betrokkenheid te beïnvloeden is. Daarbij wordt aandacht besteed aan de leeromgeving (school- en klasniveau) en aan bovengenoemde achtergrondkenmerken van de student.

Deze achtergrondkenmerken staan centraal bij enkele sociologische benaderingen van studiekeuzegedrag. Bourdieu (1986) gebruikt het concept kapitaal om het geheel van relevante achtergrondkenmerken aan te geven. Jonge mensen krijgen van hun ouders en omgeving een startkapitaal mee dat ze gaandeweg hun onderwijsloopbaan zelf uitbreiden. Het gaat dan niet alleen om financiële middelen, maar ook sociale vaardigheden en netwerken en cultureel kapitaal (ervaringen, verwachtingen). Hoe meer dat kapitaal en vooral de samenstelling van dat kapitaal past bij de verwachtingen en andere hulpbronnen die in de academische en sociale gemeenschap van de ho-instelling aanwezig worden verondersteld, hoe groter de kans dat de student beter geïntegreerd zal zijn en hoe kleiner de kans dat hij of zij voortijdig vertrekt.

Bean en Vesper (1992) hebben hier nog een externe component aan toegevoegd. Zij richten de aandacht op factoren die zorgen voor 'afleiding' en vermindering van de betrokkenheid bij de instelling. Als er alternatieve opleidingen of instellingen zijn dan kunnen de gepercipieerde voordelen van die alternatieven de betrokkenheid bij de instelling doen verminderen. Een andere afleiding die met het economisch kapitaal van de student te maken heeft is de bijbaan. Als er meer tijd aan een bijbaan wordt besteed kan er minder tijd aan onderwijs worden besteed, hetgeen tot mindere academische prestaties en daardoor tot minder academische integratie kan leiden. Andere afleidingen, zoals studentactivisme, zou ook tot minder tijdbesteding aan studie kunnen leiden, maar kan ook een stimulans voor de betrokkenheid bij de instelling zijn.

Naast de oriëntatie op integratie als bepalende factor voor studiesucces is er in de literatuur ook veel aandacht voor de gepercipieerde kosten en baten van de beslissing te gaan of blijven studeren. Deze economische benaderingen gaan ervan uit dat die beslissing een rationele keuze is. Die rationaliteit is echter geen economische rationa- 
liteit, maar een 'bounded rationality' (Simon, 1976) waarbij niet de objectieve kosten en baten worden meegenomen, maar de door de student gepercipieerde kosten en baten. Een soortgelijke benadering komen we tegen in de 'behavioural economics' literatuur. Daarin spelen het gebruik van vuistregels en referentiepunten bij besluitvorming onder onzekerheid een belangrijke rol. Welke vuistregels worden gebruikt en waar de referentiepunten liggen wordt voor een groot deel bepaald door de omgeving van de student (Vossensteyn, 2005) .

Eccles (2005) heeft deze benadering uitgewerkt in een verwachte waarde model ('expectancy value model', zie hieronder voor een vereenvoudigde weergave) waarin het zelfbeeld van de student ('self-concept') een centrale rol speelt. Het 'self-concept' heeft een grote invloed op de inschatting van de kosten van de gedragsalternatieven (blijven studeren of stoppen) en de kans op succes. Het 'self-concept' op zijn beurt wordt beïnvloed door de perceptie van de verwachtingen van de omgeving en stereotypen en rolpatronen en door de academische prestaties in het verleden.

FIGUUR 2.2 Vereenvoudigde weergave van het Expectancy value model van Eccles

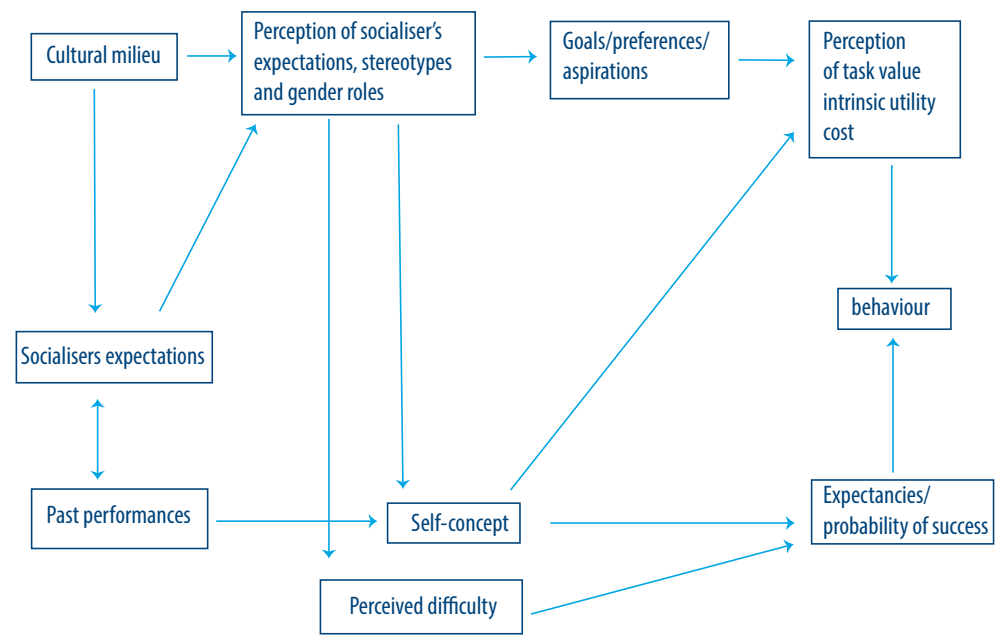

Self-efficacy, het geloof dat iemand heeft in zijn/haar eigen capaciteiten om bepaalde taken te verrichten, is een belangrijk aspect van het self-concept dat direct en indirect van invloed is op academische prestaties (Vantieghem et al., 2014). Mede op grond van bovenstaande theoretische benaderingen bij de verklaring van studiesucces hebben we vier mechanismes onderscheiden. Bij de beschrijving van die mechanismes gaan we in op de vraag of het verklaringsmechanisme inzicht kan verschaffen in de verschillen in studiesucces tussen jongens en meisjes. 


\subsection{Mechanismen}

Hierboven hebben we enkele gangbare theoretische benaderingen bij het zoeken naar factoren die studiesucces beïnvloeden geschetst. Nu de genderongelijkheid weer stijgt op de politieke en bestuurlijke agenda's gaan beleidsmakers wederom op zoek naar instrumenten die de genderongelijkheid tot aanvaardbare proporties kunnen terugbrengen. In de beleidsliteratuur komen we vier typen van dergelijke instrumenten tegen. Volgens welke mechanismen deze instrumenten het studie(keuze)gedrag kunnen beïnvloeden wordt hieronder beschreven. Daarbij richten we ons vooral op literatuur waarin een relatie met gender wordt gelegd.

\subsubsection{Integratie van studenten (academisch en sociaal)}

Dit mechanisme ligt ten grondslag aan een groot deel van de literatuur over de invloed van sociaal culturele factoren op studiesucces. De basisveronderstelling is dat een betere academische en sociale integratie van een student zal bijdragen aan betere resultaten van die student. In de verklaringsmodellen van Tinto spelen vooral non-cognitieve vaardigheden, verwachtingen en houdingen van studenten een belangrijke rol. Bij Nelissen en van der Boon (2014) komt gender niet in de analyses naar voren, maar ook zij komen tot de conclusie dat het gevoel zich thuis te voelen en de tevredenheid over de studiekeuze bij sommige opleidingen positief samenhangen met studiesucces (Nelissen en van der Boon, 2014).

De invloed van gender verloopt voor een belangrijk deel via deze kenmerken die op hun beurt van invloed zijn op de sociale integratie ('belonging') en op die manier op studiesucces. Meisjes scoren vaak beter op werkhouding, motivatie, communicatieve vaardigheden, waarbij 'beter' refereert aan een werkhouding, motivatie en communicatieve vaardigheden die een positieve bijdrage leveren aan de sociale en academische integratie.

Van Houtte relateert de lagere prestaties van jongens in Vlaamse scholen aan een verschil in 'academic culture' (van Houtte, 2004). De cultuur onder jongens is minder gericht op studie dan de meisjescultuur, hetgeen tot een verschil in schoolprestatie leidt. Dit verband gold overigens voor algemene scholen. Op technische scholen kon dat verband niet worden aangetoond. In het onderzoek aan een Britse universiteit is dit verband ook aangetoond (Cotton et al., 2015).

Ook in het mbo is de sociale integratie of 'emotional engagement' een factor die aandacht krijgt. Elffers geeft aan dat risicogroepen (studenten die een hogere kans op uitval hebben) moeite hebben om ondersteuning te vinden bij ouders, vriendengroep of algehele sociale netwerk (Elffers, 2011). Hierdoor voelen ze zich minder betrokken bij de school en hebben ze een grotere kans op uitval. Gender (jongens) en etniciteit (allochtone herkomst) zijn onderscheidende kenmerken van de risicogroep. In een Deens onderzoek wordt de beperkte betrokkenheid van jongens in mbo scholen ook in verband gebracht met de subcultuur waarin een "echte jongen" zich afzet tegen de 
modelstudent: gedragsmatige betrokkenheid past niet in die subcultuur (Jørgensen, 2015). Dit sluit aan bij Amerikaans onderzoek waar het binnen de'non-white' subcultuur past om gedragsmatig niet betrokken te zijn. In met name de Engelse literatuur is de laatste jaren veel aandacht voor de groepscultuur en de invloed die dit op studiesucces kan hebben. Het is onder jongens 'uncool to work' en in het Engelse secundair onderwijs heeft dit zich ontwikkeld tot een zodanige aard en omvang dat dit het studiesucces van bepaalde groepen jongens (en hun klasgenoten) ernstig bedreigd. Hoewel dit zogenaamde laddism vooral in sociaal lagere klassen in de extreme vormen voorkomt zijn onder andere groepen en in het hoger onderwijs andere vormen van negatieve jongensculturen aanwezig. In het hoger onderwijs is ook in andere Angel Saksische systemen het 'effortless achievement' tot norm verheven, hetgeen vooral onder mannelijke studenten een negatieve invloed op de gedragsmatige en academische betrokkenheid heeft, wat negatieve gevolgen voor de prestaties heeft (Jackson en Dempster, 2009; Jackson et al., 2015).

We hebben in de literatuur niet veel onderzoeken aangetroffen die aandacht besteden aan de relatie tussen integratie en studiesucces. In de literatuur is veel meer aandacht voor de contexten die een bijdrage kunnen leveren aan de integratie van studenten. Gezien het centrale karakter van de relatie integratie en studiesucces zou je mogen verwachten dat de achterliggende assumptie meer empirische aandacht zou krijgen.

\section{Contexten}

De leeromgeving is een contextfactor die vooral bij dit mechanisme van invloed is. De leeromgeving is het geheel aan sociale settingen waarin het formele leren in een school plaatsvindt (Fraser et al., 1982). Daarbij gaat het over de relaties tussen leerlingen, relaties tussen leerlingen en leraar, relaties tussen leerling en onderwerp en onderwijsmethode en de percepties van leerlingen van structuurkenmerken van de setting. Elementen van die beschrijving komen in het onderstaande aan bod.

De groei van de genderongelijkheid in studiesucces wordt voor een deel toegeschreven aan de introductie en uitbreiding van alternatieve onderwijsmodellen. In deze modellen zijn andere vaardigheden belangrijker geworden voor studiesucces. Het gaat daarbij om vaardigheden die meisjes in het algemeen meer eigen zijn dan mannen (zie daarvoor ook het volgende hoofdstuk). Er is niet één alternatief onderwijsmodel maar de alternatieve modellen verschillen van het traditionele onderwijsmodel in de rol van de leerling/ student, de rol van de docent, de wijze waarop de lesstof is georganiseerd en de wijze waarop de toetsing is georganiseerd.

In de traditionele modellen is de docent de belangrijkste informatiebron, is er geen sprake van probleemgestuurd of projectgebonden onderwijs, is er vaak sprake van grootschalige leeromgevingen en vindt toetsing op een beperkt aantal momenten plaats. De autonomie van de student is in dit model (zeer) beperkt. 
In 'alternatieve' modellen is de docent niet meer de belangrijkste informatiebron en is er sprake van enige vorm van probleemgestuurd of projectgebonden onderwijs. Toetsing vindt gedurende het jaar op een groot aantal momenten plaats en de leeromgeving wordt vaak als kleinschalig omschreven. De autonomie van de studenten is relatief groot.

Het onderwijsmodel kan, onder bepaalde voorwaarden, van invloed zijn op studiesucces. Deze invloed verloopt enerzijds via de mate van sociale integratie en anderzijds via de match tussen onderwijsmodel en individuele leerstijl. Severiens et al. (2014) geven aan dat studenten in studentgerichte en kleinschalige modellen een grotere kans op succes hebben dan studenten in traditionele college modellen. Wat de voorwaarden zijn en hoe de invloed op studiesucces verloopt, is door Severiens et al. in een onderzoek onder 750 bedrijfskunde studenten onderzocht. De invloed verloopt via het gevoel dat een student zich thuis voelt (sociale integratie, 'belonging') dat positief samenhangt met inspanning en betrokkenheid van de student, die op hun beurt van invloed zijn op de tijd die aan de studie wordt besteed. In het model is die tijd van invloed op de kans op studiesucces. Severiens et al. vinden geen verschil in studiesucces tussen beide onderwijsmodellen, maar de achterliggende invloedrelaties verschillen wel. In het traditionele collegemodel is het van groter belang dat studenten zich thuis voelen dan in het studentgerichte model, want het ontbreken van dat gevoel heeft in het traditionele model meer impact op de leerprestaties dan in het studentgerichte model. Uit een eerder onderzoek (Severiens en Schmidt, 2008) kwam naar voren dat de sociale integratie van studenten in probleem gestuurd onderwijs hoger was dan van studenten in traditionele college georiënteerde onderwijsmodellen. In één van de gesprekken die ten behoeve van hoofdstuk 7 zijn gevoerd is de suggestie gewekt dat dit voor een deel het gevolg is van zelfselectie: studenten zouden veel bewuster voor een pgo-opleiding kiezen dan studenten die voor een andere opleiding kiezen. Meeuwisse et al. (2010a) hebben onderzocht of het gebruikte onderwijsmodel van invloed is op de integratie van studenten en of die invloed verschilt naar etnische achtergrond. Dit laatste bleek inderdaad het geval. Allochtone studenten voelen zich meer thuis in een model waarin duidelijke formele relaties tussen student en docent en studenten onderling bestaan, terwijl voor autochtone studenten meer informele relaties bijdragen aan een gevoel van 'behoren bij'. Dit laatste is voor autochtone studenten ook positief gerelateerd aan studieresultaat, terwijl dit verband voor allochtone studenten niet is aangetroffen. Meeuwisse et al. maken geen onderscheid naar gender.

Ook in het mbo is aandacht voor de invloed van alternatieve onderwijsmodellen op de betrokkenheid van studenten en de invloed die dit heeft op het studiesucces. Een grotere mate van autonomie van de student zou leiden tot minder gedragsmatige betrokkenheid ('behavioral engagement'). Jongens zouden meer moeite hebben met meer zelfstandigheid (zo zouden jongens minder goed kunnen plannen dan meisjes), maar volgens Elffers (2011) speelt bij de invloed die de mate van zelfstandigheid op betrokkenheid heeft de opleidingsdomein een grote rol. Zo bleken techniekstudenten, voornamelijk jongens, meer gedragsmatig betrokken te zijn als ze vinden dat ze veel 
zelfstandig moeten werken, terwijl studenten in zorg \& welzijnopleidingen, vooral meisjes, juist meer gedragsmatig betrokken zijn als ze vinden dat ze weinig zelfstandig moeten werken. Verschillen in de interpretatie en implementatie van zelfstandige werkvormen tussen de verschillende opleidingssectoren lijken het genderverschil in het verband tussen zelfstandig werken en betrokkenheid te kunnen verklaren (Elffers, 2011).

In de Britse discours over onderwijshervormingen was het begrip 'independent learner' tien jaar geleden een sleutel begrip. In een kwalitatief onderzoek onder studenten van een Britse universiteit komt de onderzoeker tot de conclusie dat een alternatief onderwijsmodel (hier als 'the independent learner' omschreven), niet voor alle studenten een positief effect heeft op de leerprestaties (Leathwood, 2006). De sterke nadruk op onafhankelijkheid ('self directed learning') heeft een negatieve invloed op de sociale integratie waardoor vooral vrouwen niet goed zullen gedijen.

De leeromgeving is hiervoor beschreven als een geheel van sociale settingen waarin het formele leren plaats vindt. De samenstelling van de klassen/groepen is daarom een belangrijk element in het verklaren van verschillen in studiesucces (dit wordt ook wel als het compositie-effect aangeduid).

De samenstelling van de groep naar gender speelt een rol bij zowel door mannen gedomineerde groepen (die veelal in bèta en techniek opleidingen voorkomen) als bij door vrouwen gedomineerde groepen (vooral in onderwijs en geesteswetenschappen). De veronderstelling is dat een evenwichtig verdeelde studentpopulatie bijdraagt aan sociale integratie en aan het gevoel van erbij horen. Uit een onderzoek onder Nederlandse studenten blijkt dat een onevenwichtige samenstelling van de studentpopulatie invloed heeft op studiesucces en de redenen waarom studenten hun studie staken. Deze relatie ligt voor vrouwen gedomineerde opleidingen anders dan voor mannen gedomineerde opleidingen (Severiens en ten Dam, 2012). Mannen in vrouwen gedomineerde opleidingen vallen meer uit vanwege financieel economische redenen en vrouwen vallen eerder uit in mannen gedomineerde opleidingen vanwege motivatieproblemen. Ook uit een onderzoek onder Noorse studenten blijkt dat de samenstelling van de studentenpopulatie voor mannen geen invloed op de uitval heeft, maar voor vrouwen wel: zij vallen minder uit in door vrouwen gedomineerde opleidingen (Mastekaasa en Smeby, 2008).

In het mbo is de samenstelling van de studentpopulatie ook onderzocht in relatie tot het risico op uitval. In dat onderzoek bleek de samenstelling geen duidelijk effect had op de kans op uitval (Herweijer, 2008).

In de literatuur komt de onevenwichtige samenstelling vooral aan de orde in de context van de bèta en techniek discussie. Het beperkte aandeel vrouwelijk bèta en techniek studenten wordt algemeen gezien als een probleem, omdat het op een grote onderbenutting van het bèta-technisch potentieel zou duiden. Naast de onevenwichtigheid in instroom zijn ook de verschillen in rendement/uitval tussen mannen en vrouwen in 
bèta en techniek veelvuldig onderzocht. Hieruit komt naar voren dat vrouwen het in de mannen gedomineerde techniek opleidingen niet slechter doen dan mannen. Een veelgenoem de veronderstelde verklaring hiervoor is dat voor de keuze voor een gender non-traditionele opleiding al een selectie heeft plaatsgevonden. Vrouwen zullen die keuze gemotiveerder maken dan mannen, hetgeen de invloed van de onevenwichtigheid in de studentenpopulatie en het daaruit mogelijk voortvloeiend gevoel van er minder bij te horen wellicht teniet doet (Haemmerlie Montgomery en Montgomery, 2012). De empirische onderbouwing voor deze veronderstelling is echter beperkt. Een opvallend onderzoek in dit verband is een Amerikaans onderzoek (Robst et al., 1998) waaruit bleek dat in bèta techniek opleidingen waarin vrouwelijke docenten sterk zijn ondervertegenwoordigd een toename van het aantal vrouwelijke docenten de kans op studiesucces van vrouwen vergroot en dat dit effect het grootst is als er relatief weinig vrouwelijke studenten zijn. De aanwezigheid van vrouwelijke docenten compenseert dan de afwezigheid van vrouwelijke medestudenten en leidt tot een grotere integratie.

In de algemene literatuur over uitval wordt een groot aantal kenmerken van de onderwijsinstelling genoemd die van invloed zijn op studiesucces. Daarbij gaat het om de wijze waarop de opleiding is georganiseerd en de middelen die voor de opleiding beschikbaar zijn. Beperkte voorzieningen hebben een (beperkte) negatieve invloed op de kans op uitval (Heublein et al., 2003). Ook de wijze waarop de (bureaucratische) regels en regelingen met studenten worden gecommuniceerd kunnen, via een gebrekkige sociale integratie, leiden tot mindere studieresultaten (Kuh et al., 2006). Kok (2012) is in Nederland nagegaan wat de invloed van de kwaliteit van voorzieningen is op de onderwijsprestaties. Zo blijkt de omvang van de hogeschool negatief aan prestaties gecorreleerd. Studiesucces hangt, zij het in beperkte mate, positief samen met de kwaliteit van de aan onderwijs gerelateerde diensten (ICT- voorzieningen, collegeruimten), comfort diensten (front-office, printfaciliteiten) en religieuze identiteit. De invloed van de omvang van de groep/klas wordt in de literatuur wel naar voren gebracht, veelal in combinatie met het gehanteerde onderwijsmodel. Zo zou een grotere groep tot minder gemotiveerde en betrokken studenten leiden, hetgeen de resultaten niet ten goede komt. Herweijer constateert dat de omvang geen directe relatie heeft met de prestaties in het mbo (Herweijer, 2008). Of en zo ja welke rol gender bij de invloed van kenmerken van de onderwijsinstelling op studiesucces speelt komt in de beschikbare literatuur nauwelijks aan de orde.

Claessen somt een aantal kenmerken van de school en schoolorganisatie op die kunnen bijdragen aan het voorkomen van het ontstaan van (meer) verschillen in prestaties tussen jongens en meisjes (Claessen, 2013). Deze kenmerken zijn voor een groot deel gerelateerd aan non-cognitieve vaardigheden en zijn we ook verspreid in de internationale literatuur tegengekomen. Het gaat dan onder andere om het belang van extracurriculaire activiteiten, ouderbetrokkenheid, brede leerinhoud, variatie in leerinhoud, aanbod van activerende werkvormen, groepssamenstelling en de houding en verwachtingen van docenten. 
Sonnert et al. geven aan dat kenmerken van de instelling van invloed zijn op de relatie gender en prestatie in bèta en techniek (Sonnert en Fox, 2012). Daarbij gaat het vooral om de middelen die de instelling aanwendt voor speciale vrouwenprogramma's. Er is ook een invloed van het type instelling (Carnegie classificatie) op prestaties van vrouwen aangetroffen, maar hoe deze invloed verloopt, is niet helder. Het voorgaande sluit aan bij een constatering die ook door Jacobs (Jacobs, 1996) wordt gemaakt. Hij geeft aan dat de gender ongelijkheden in het algemeen wel zijn afgenomen, maar dat dat bij de prestigieuze Amerikaanse universiteiten nog lang niet het geval is. Of dit het gevolg is van een specifieke mix van disciplines (veel bèta en techniek), hoge collegegelden of andere kenmerken kan op grond van de literatuur niet worden gezegd. Jacobs roept op tot nader onderzoek, hetgeen met de groeiende aandacht voor differentiatie in niveau (University Colleges, excellentieonderwijs) wellicht ook in Nederland een relevante oproep is.

\subsubsection{Inzet en cognitieve vaardigheden}

Het tweede mechanisme betreft de cognitieve vaardigheden (de kennisachtergrond) en het studiegedrag (met name de inzet van de student). ${ }^{4}$ De veronderstelling is dat de kans op studiesucces hoger is als de kennisachtergrond (de academische bagage) beter is c.q. beter aansluit op de eisen van de opleiding en de inzet, de tijd besteed aan de studie hoger is.

Cognitieve vaardigheden zijn positief aan studiesucces gerelateerd (Heublein et al., 2003; Lassibille en Navarro Gomez, 2008). Als de vooropleiding als benadering voor de cognitieve vaardigheden bij aanvang van de studie worden gebruikt blijkt uit Nederlands onderzoek dat de kans op uitval voor studenten in een hbo-opleiding met een vwo achtergrond kleiner dan voor studenten met een havo-achtergrond (Nelissen en van der Boon, 2014). Ook in onderzoeken onder universitaire studenten (de Koning en Loyens, 2011; Meeuwisse et al., 2011; Torenbeek et al., 2011) en in het mbo (Herweijer, 2008) blijkt de vooropleiding van groot belang bij de verklaring van uitval in het eerste jaar. De invloed van gender is in deze Nederlands onderzoeken niet meegenomen. Het CBS heeft cijfers over de vooropleiding van eerstejaars in het hbo. Daaruit blijkt dat vrouwen net iets vaker met een vwo-diploma instromen dan mannen. Het verschil is beperkt (2014/15: 21,3\% bij de meisjes en 20,4\% bij de jongens) en het loopt de laatste jaren terug (CBS, 2015).

De literatuur geeft geen eenduidig beeld over de relatie tussen studieresultaten en de tijd besteed aan studie: sommige onderzoekers vinden geen relatie, anderen wel. Er is ook geen duidelijke negatieve relatie tussen prestaties en de tijd die niet aan studie (maar bijvoorbeeld aan baantjes) wordt besteed. Zo blijkt uit vooral Amerikaanse onderzoek dat er aanwijzingen zijn dat studie-gerelateerde bijbaantjes en activisme wel leiden tot meer betrokkenheid en daardoor betere resultaten. In een Nederlands onderzoek wordt geconcludeerd dat verschillen in tijd aan zelfstudie niet wezenlijk bijdragen aan

$4 \quad$ In de literatuur over studiesucces in secundair onderwijs is dit aangeduid met 'behavioral engagement'. 
studieresultaat, maar tijdbesteding aan contacturen heeft wel een wezenlijk invloed op studiesucces (Meeuwisse et al., 2011).

Zijn er op dit punt verschillen tussen jongens en meisjes gevonden in de literatuur? In een onderzoek aan een Britse universiteit is een relatie gelegd tussen gender enerzijds en inzet en tijdbesteding anderzijds: mannen blijken minder tijd te besteden aan hun studie dan vrouwen. Ook volgens Bean en Vesper en Jørgensen et al. werken meisjes doorgaans harder, doelgerichter en zelfstandiger dan jongens en halen daardoor gemiddeld hogere cijfers en studeren sneller (Bean en Vesper, 1992; Jorgensen et al., 2009). Vooral in de Angelsaksische literatuur wordt tijdbesteding en gender aan elkaar gerelateerd in de discours over 'uncool to work' en 'effortless achievement' (Jackson en Dempster, 2009; Jackson et al., 2015). In het ideaaltypische beeld van mannelijkheid dat in het secundair onderwijs en in toenemende mate ook in het hoger onderwijsterrein wint past hard werken niet. Oorspronkelijk was dit beeld dominant onder jonge'working class' mannen maar met name in de VS is het ook onder 'middle class' mannen populair geworden.

\section{Contexten}

In een (empirisch) beperkt onderzoek onder Nederlandse bedrijfskunde studenten gaan Meeuwisse et al. (2013) na of verschillen in tijdbesteding een verklaring zou kunnen zijn voor verschillen in studieprestatie tussen studenten met een allochtone en autochtone achtergrond. De verschillen in tijdbesteding blijken beperkt te zijn. Door de zeer beperkte en scheef verdeelde steekproef kunnen geen uitspraken worden gedaan over de relatie met gender.

Bij dit mechanisme spelen elementen van de leeromgeving en het onderwijsmodel ook een rol. In enkele onderzoeken staat de match tussen onderwijsmodel en leerstijl centraal. Een leerstijl wordt als een geprefereerde combinatie van cognitieve en psychomotorische vaardigheden omschreven. Als leerstijl en onderwijsmodel op elkaar aansluiten is de kans groter dat de prestaties ook beter zijn. In de literatuur over leerstijlen worden verscheidene typen leerstijlen onderscheiden. Een veelgebruikte indeling is gebaseerd op een model van Kolb, waarin vier typen worden onderscheiden: 'accomodator' ('feel and do'), 'diverger' ('feel and watch'), 'assimilator' ('think and watch') en 'converger' ('think and do') (Kolb, 1984). De relatie tussen leerstijl en gender is niet heel duidelijk. Severiens en ten Dam vinden geen relaties tussen leerstijl en gender, maar tekenen daarbij aan dat een dergelijke relatie mogelijk niet zichtbaar is door de grote invloed die andere factoren, zoals sociale klasse en groepssamenstelling op het studiegedrag van studenten hebben. Bovendien zijn de beschikbare meetinstrumenten genderneutraal waardoor ze mogelijke verschillen niet kunnen registreren (Severiens en ten Dam, 1999). Andere onderzoekers vinden wel een relatie tussen gender en leerstijl. Volgens Philbin et al. blijkt dat mannen vaker een leerstijl hebben die aansluit bij traditionele les/college gerichte onderwijsmodellen dan vrouwen (Philbin et al., 1995). In een onderzoek onder vwo-leerlingen (Reints, 2013) wordt een onderscheid gemaakt tussen jongensachtige en meisjesachtige leerstijlen. Ook deze onderzoeker komt tot 
de conclusie dat de aansluiting van het onderwijsmodel bij de leerstijl van invloed is op de prestaties. Om de prestaties van jongens te verbeteren pleit de onderzoeker niet zozeer voor een generieke aanpassing van de leeromgeving richting jongensachtige elementen, maar voor digitale, facultatieve 'jongensachtige' aanvullingen. Voor een overzicht van meer jongensachtig gedrag verwijzen we naar Maréchal-van Dijken et al (2012).

Legewie en DiPrete geven aan dat de invloed van het onderwijsmodel op studiesucces ook voor een deel via de studiehouding verloopt (Legewie en DiPrete, 2012). De studiehouding wordt voor een belangrijk deel bepaald door de 'peer' groep. Dat geldt voor zowel jongens als meisjes. Er zijn echter aanwijzingen dat het onderwijsmodel vooral bij jongens van invloed kan zijn op hoe die 'peer pressure' werkt. Krupp et al. (2014) geven aan dat in een competitieve schoolomgeving met duidelijke oriëntatie op schoolprestaties de jongenscultuur meer gericht zal zijn op prestaties waardoor de prestaties hoger zijn, terwijl dit bij meisjes geen effect heeft op de gemiddelde studiehouding. Ze hebben ook gekeken of het gebruik van meer competitie-elementen in het onderwijs een positieve invloed op de motivatie hebben, maar zij konden geen invloed vaststellen.

Op grond van het beperkte onderzoek dat op dit terrein beschikbaar is hebben we maar weinig aanwijzingen kunnen vinden dat de verschillen in studiesucces tussen jongens en meisjes via dit mechanisme (mede) tot stand komt.

\subsubsection{Verwachtingen en preferenties over studie en arbeidsmarkt}

Uit de literatuur komt naar voren dat de verwachtingen en preferenties van studenten ten aanzien van de opleiding, de zwaarte, het beroepsbeeld en de verwachte arbeidsmarktpositie van belang zijn voor studiesucces. Soms hebben studenten een heel andere voorstelling van een opleiding dan dat het in de praktijk blijkt te zijn, hetgeen tot uitval of vertraging kan leiden.

Informatie over de (toekomstige) positie op de arbeidsmarkt kan door mannen anders gewaardeerd worden dan door vrouwen, zoals uit een onderzoek van Severiens en ten Dam blijkt. De verwachting dat de toekomstige arbeidsmarktpositie van afgestudeerden van vrouw- gedomineerde opleidingen relatief slecht is, is voor mannen in die opleidingen een belangrijkere reden om de studie te staken dan voor vrouwen (Severiens en ten Dam, 2012).

De beschouwingen over de verwachte positie op de arbeidsmarkt zijn een onderdeel van een veel bredere discussie over de employability van studenten. Hoe makkelijk kunnen afgestudeerden een baan of weer een vergelijkbare baan vinden? Naast de cognitieve vaardigheden spelen hier ook non-cognitieve vaardigheden een rol. In de gangbare modellen die verschillen in employability verklaren speelt ook werkervaring een rol. Daarbij wordt vaak een ruime invulling aan dat laatste begrip gegeven en worden ook extra curriculaire activiteiten als werkervaring geïnterpreteerd. Meer extra-curriculaire activiteiten zou dan kunnen leiden tot een betere positie op de arbeidsmarkt. Stevenson 
en Clegg hebben naar de extra-curriculaire activiteiten en de verschillen daarin tussen jongens en meisjes gekeken. Het blijkt dat vrouwen minder actief zijn in extra-curriculaire activiteiten en dat ze het nut hiervan voor het verbeteren van hun toekomstige arbeidsmarkt positie ook minder inschatten (Stevenson en Clegg, 2012). Dit zou voor een deel een verklaring kunnen zijn voor het gegeven dat meisjes het ondanks de betere prestaties in het onderwijs (wellicht ook deels te verklaren door de constatering dat ze door minder extra-curriculaire activiteiten meer tijd aan de studie kunnen besteden; zie hieronder) minder goed doen op de arbeidsmarkt.

\section{Contexten}

De verwachtingen en percepties van studenten worden sterk beïnvloed door de sociale omgeving. Vooral de rol van ouders en 'peer groups' wordt in de literatuur naar voren geschoven. Mastekaasa en Smeby (2008) geven aan dat de sociale omgeving en vooral ouders van invloed zijn op gender traditionele studiekeuze: Noorse vrouwelijke studenten geven vaker aan dat ze door ouders en vrienden zijn aangemoedigd om een traditionele vrouwen studie te doen dan mannen. Dit heeft echter geen invloed op de gevonden verschillen in de kans op uitval. Het blijkt dat in vrouw gedomineerde opleidingen vrouwen een veel kleinere kans op uitval hebben dan in man gedomineerde of gender gelijk verdeelde opleidingen, ongeacht of de ervaren sociale druk groot of klein is. In de Nederlandse context zijn er aanwijzingen dat etnische achtergrond samenhangt met de verwachtingen en de redenen om een hbo-studie te staken (Meeuwisse et al., 2010b). Allochtone studenten staken hun studie vaker omdat ze teleurgesteld zijn in de kwaliteit van de opleiding en de inhoud van de opleiding. Autochtone studenten haken vaker af vanwege een gebrek aan cognitieve vaardigheden.

\subsubsection{Perceptie van kosten en baten van studeren}

Over het laatste hier genoemde mechanisme, de invloed van de gepercipieerde (financiële) lasten en baten op het studie(keuze)gedrag is veel geschreven. Vanuit de onderliggende rationele keuze theorie wordt allereerst onderscheid gemaakt tussen werkelijke kosten en baten en gepercipieerde kosten en baten. Verschillen tussen mannen en vrouwen worden veelal in verband gebracht met gender specifieke verwachtingspatronen (vanuit de omgeving), verschillen in risico-aversie en tijdpreferenties, maar ook met daadwerkelijke verschillen in de baten van een opleiding in termen van de positie van vrouwen op de arbeidsmarkt. Vrouwen schatten de opbrengsten van een diploma lager en onzekerder in dan mannen. Dit komt mede omdat vrouwen, vrouwen die al een diploma hebben (en die een lager inkomen hebben) als referentiepunt gebruiken. Ook staan vrouwen afwijzender tegenover risico's dan mannen. Dit zou ertoe leiden dat vrouwen eerder een kortere en 'makkelijker' opleiding kiezen dan mannen (Vossensteyn, 2005).

Bij de kosten worden naast de directe kosten (collegegeld en kosten van levensonderhoud) ook indirecte kosten onderscheiden (inkomsten die een student tijdens de studie misloopt). Eenzelfde onderscheid tussen direct en indirect wordt ten aanzien van baten 
gemaakt: studiefinanciering of belastingvoordelen als directe baten en betere positie op de arbeidsmarkt als indirecte baten (Vossensteyn, 2005).

Jacob zet de verwachte baten naast non-cognitieve vaardigheden als mogelijke verklaring voor verschillen tussen jongens en meisjes in deelname (Jacob, 2002). 'Goede' noncognitieve vaardigheden dragen bij aan betere prestaties in het voortgezet onderwijs en daardoor aan (gepercipieerde) kans op succes in het hoger onderwijs. Het blijkt dat meisjes vaker over de goede non-cognitieve vaardigheden beschikken dan jongens, hetgeen tot hogere (gepercipieerde) baten van een opleiding leidt. De onderzoekers zien de resultaten als een aansporing om verder onderzoek te doen naar schoolkenmerken die van invloed kunnen zijn op de non-cognitieve vaardigheden.

Een opmerkelijke relatie tussen studiesucces (in het bijzonder de tijd tot afstuderen), toekomstig inkomen en gender wordt door Taniguchi beschreven (Taniguchi, 2005). Ze toont aan de hoogte van het saldo van baten en kosten van invloed is op de snelheid van afstuderen. Ze kijkt daarbij vooral naar de misgelopen inkomsten tijdens de studie ('foregone earnings'): hoe sneller je afstudeert hoe minder toekomstig inkomen je misloopt. Opmerkelijk is dat Taniguchi dit effect koppelt aan geslacht. Vergeleken met vrouwen zullen mannen sneller hun diploma behalen omdat het misgelopen inkomen hoger is dan het misgelopen inkomen van vrouwelijke afgestudeerden. De prikkel om snel af te studeren zou daarom voor mannen groter zijn dan de prikkel voor vrouwen.

Waarom gaan zoveel meisjes naar het hoger onderwijs en zijn ze daar zo succesvol terwijl de te verwachte baten achterblijven ten opzichte van jongens? In Amerikaans onderzoek (Mickelson, 1989) worden vier mogelijke verklaringen voor gegeven:

- 'Differential Reference Group Theory': vrouwen zijn zich bewust van hun verminderde status in relatie tot mannen, maar wanneer zij evalueren wat een eerlijke opbrengst is van onderwijsprestaties, kijken vrouwen vaak naar andere vrouwen in plaats van mannen. Dit wordt aangetoond door te laten zien dat met name voor hoger opgeleiden de gender structuur van beroepen overeind blijft (Mickelson, p. 159).5

- 'The Pollyanna Hypothesis': Adolescente meisjes zijn opportunistisch en verwachten dat ze in onderwijs en hun carrière gelijk behandeld worden, omdat seksisme een begrip van het verleden is. Volgens deze hypothese leven meisjes nog in een 'perfecte wereld' waar ze nog niet met genderinvloeden te maken hebben gehad. Zo worden ze tijdens hun middelbare schoolperiode niet of slechts in beperkte mate geconfronteerd met verschillen in arbeidsmarktpositie tussen mannen en vrouwen. ${ }^{6}$

- 'Social Powerlessness Theory' gaat ervan uit dat vrouwen het huwelijk zoeken om een sociaal en financieel zekere positie te verwerven omdat een zelfstandige zekere positie door de ongelijkheid in kansen op de arbeidsmarkt erg onzeker is.

$5 \quad$ N.B. Vrouwen die 12-25 uur per week werken hebben i.v.m. mannen een hoger gemiddeld bruto loon. Naar mate vrouwen meer uren werken, hoe groter het beloningsverschil tussen mannen en vrouwen wordt (CBS, 2014).

6 N.B. Informatie in Studie in Cijfers wordt niet uitgesplitst naar geslacht. 
Onderwijsprestaties zijn in die optiek niet voor een carrière, maar voor het huwelijk. Volgens DiPrete en Buchman (2005) zijn de verwachte baten van studeren voor vrouwen de afgelopen jaren sneller toegenomen dan voor mannen. De gepercipieerde subjectieve baten zijn van groot belang door de beslissing om deel te nemen en de opleiding af te maken. Bij die baten kijken ze niet alleen naar verwachte inkomen, maar ook naar de kans om hoger opgeleide partners te vinden en de kans dat een relatie (met een hoger opgeleide) meer bestendig is. De resultaten van Ochsenfeld ondersteunen de 'gender role' theorie waar de man als kostwinner wordt gezien en voor de vrouw een belangrijkere rol in opvoeding en huishouden wordt gezien (Ochsenfeld, 2014). In een onderzoek naar de reden waarom vrouwenstudies minder opleveren op de arbeidsmarkt dan mannenstudies concludeert Ochsenfeld (2014) dat er sprake is van zelfselectie. Hij geeft aan dat er banen zijn die vooral financiële baten opleveren en andere banen die veel meer sociale en culturele baten opleveren. ' Volgens Ochsenfeld (2014) is dat niet omdat in de tweede categorie meer vrouwen werkzaam zijn, maar omdat die structuur van baten beter aansluit bij noncognitieve vaardigheden van vrouwen en de daaraan gerelateerde motivatie.

- 'Sex Role Socialization theory': De belangrijkste motivatie voor vrouwen om in het onderwijs te presteren is een oriëntatie naar anderen (sociale goedkeuring en gezien worden als 'good girl'). Bij jongens ligt de nadruk op meer op zelfstandigheid en eigen behoeften. Deze theorie zien we ook terug in sociaal psychologisch onderzoek (Spencer et al., 1999). Daar wordt deze verklaring naast een andere verklaring gezet: de invloed van gender stereotypering. Stereotypering creëert een context waarin het gedrag dat past bij het stereotype een verklaring is voor dat gedrag. Zo is een negatieve stereotypering dat vrouwen een wiskunde test slechter maken dan mannen van invloed op het gedrag van de vrouwen in die context (ze maken de test slechter). Als de stereotypering niet aanwezig is zijn er geen verschillen in gedrag. Deze invloed van gender stereotypering verloopt net als de invloed van 'gender role socialisation' via de motivatie die op haar beurt positief samenhangt met prestatie.

\section{Contexten}

Hoe een (potentiële) student de kosten en baten van een opleiding percipieert wordt beïnvloed door de sociaaleconomische achtergrond van de student, de 'peer' groep, maar ook door psychologische factoren als risico-aversie en tijdpreferenties (of de student baten nu prefereert boven baten later).

\subsection{Discussie}

We hebben voor deze literatuurstudie heel gericht gezocht naar de relatie tussen gender en studiesucces in mbo en hoger onderwijs. Het blijkt dat er wel onderzoek naar deze

$7 \quad$ Uit een recent Nederlands onderzoek (Berkhout, 2014) blijkt dat de niet-geldelijke baankenmerken slechts voor een zeer beperkt deel als een 'compensatie' voor de verschillen in salaris tussen mannen en vrouwen kunnen worden gezien. Alleen een korte reistijd en de mogelijkheid om in deeltijd te werken worden door vrouwen boven de hoogte van het salaris gewaardeerd. 
relatie is gedaan, maar dat dit vooral betrekking heeft op primair en secundair onderwijs en, voor zover het op het hoger onderwijs betrekking heeft, vaak genderneutraal is. Tijdens de zoektocht kwam naar voren dat een directe relatie niet vaak kan worden aangetoond. De invloed van gender wordt vaak beïnvloed door andere factoren zoals etnische afkomst, sociaaleconomische status van de ouders en kenmerken van de peergroup. Daarnaast is het onderzoek naar de mechanismen die studiegedrag beïnvloeden veelal genderneutraal. Er wordt weliswaar onderscheid gemaakt naar sekse maar aan de complexiteit van genderinvloeden wordt vaak voorbij gegaan. Gender is sociaal geconstrueerd en kent vele facetten. Studenten 'doen gender'; ze geven hun eigen invulling aan 'masculinity' door de diverse aspecten daarvan (verantwoordelijkheid, competentie, trots, agressie) op hun eigen wijze te waarderen. Welke invulling wordt gekozen is voor een deel sociaal bepaald (sociale klasse, de 'peer group', de academische discipline), maar ook andere factoren zoals leeftijd spelen daarbij een rol (de verschillen in de ontwikkeling van self-efficacy worden pas tijdens de adolescentie zichtbaar (Vantieghem et al., 2014, p. 370). Of dit laatste alleen het gevolg is van de geleidelijke vervanging van de ouders door de peers als voornaamste referentiegroep of ook door biologische factoren is een vraag die in het volgend hoofdstuk aan de orde komt.

Door de complexiteit van de relatie tussen gender en studiesucces is het moeilijk beleidsinstrumenten te identificeren die een herkenbare invloed hebben op de genderongelijkheid. Hoofdstuk 7 gaat dieper in op deze bevinding.

Uit het literatuuronderzoek komen tal van instrumenten en aangrijpingspunten voor instrumenten naar voren die kunnen worden ingezet om studiesucces aan te pakken. Welke mix van instrumenten in welke context het best zal werken is, op grond van de resultaten van de literatuurstudie, niet op voorhand te zeggen. Een gedegen analyse van een specifieke context en een verdere uitwerking van een breed verklarend model zijn nodig om tot een antwoord op die vraag te komen (die context specifieke aanpak zien we bijvoorbeeld in Nelissen en van der Boon (2014)).

Het is ook opvallend dat er weinig beleidsinstrumenten worden ontwikkeld en ingezet om de gender specifieke verschillen in studiesucces terug te dringen. Instrumenten die zich richten op het verbeteren van studiesucces zijn veelal algemeen van aard en niet specifiek gericht op gender. Instrumenten die gericht zijn op gender hebben vooral het beïnvloeden van de instroom als doel en niet het beïnvloeden van het studiegedrag.

Interventies gericht op het versterken van 'sociale integratie' zijn verspreid over de literatuur te vinden. Het inrichten van studieloopbaanbegeleiding en mentoring zijn initiatieven om studenten zich meer thuis te laten voelen in de opleiding. Bij de initiatieven gericht op de contexten hebben we vooral op het gebied van leeromgevingen resultaten gevonden. Het gebruik van alternatieve onderwijsmodellen, waarin de student een meer actieve, zelfstandige rol krijgt is toegenomen. In die nieuwe situaties zijn leerstijlen die in de traditionele modellen effectief waren minder effectief gebleken. Aanpassing van de alternatieve modellen door meer elementen op te nemen die aansluiten bij de 
traditionele (jongensachtige) leerstijlen is een aanbeveling die op het herstellen van de match tussen onderwijsvorm en leerstijl aansluit (Claessen, 2013).

We hebben weinig concrete handvatten gevonden over 'inzet en cognitieve vaardigheden' en de effectiviteit van interventies op dat terrein om genderverschillen in studiesucces terug te dringen. Meisjes werken in het algemeen wel harder dan jongens, vooral waar het zelfstudie betreft. Maar gezien de beperkte invloed van vrijetijdsbesteding aan zelfstudie op studiesucces (tijd besteed aan contacturen heeft meer effect) is onduidelijk of gender specifieke verschillen in inzet bijdragen aan verschillen in studiesucces. Dat de cognitieve vaardigheden (de academische bagage) bij het begin van een opleiding sterk samenhangen met studieprestaties wordt niet betwist, maar gender specifieke verschillen in deze zijn vooral een gevolg van selectie in de voortrajecten en zelfselectie bij studiekeuze. Interventies gericht op het wegwerken van deficiënties bij jongens zijn we daarom niet tegen gekomen.

Ten aanzien van het mechanisme "verwachtingen en preferenties over studie en arbeidsmarkt" zien we dat veel hoger onderwijsinstellingen in Nederland werken aan de verbetering van studiebegeleiding en vroegtijdige loopbaanoriëntatie om verwachtingen meer in overeenstemming met de werkelijkheid te brengen en zo het studiesucces te verhogen. Enkele instellingen gebruiken deze instrumenten ook heel specifiek om de achterstandspositie van jongens voor wat betreft studiesucces weg te werken. Zo is aan de Radboud universiteit een drietal pilots uitgevoerd op het gebied van studiebegeleiding en werkveld oriëntatie (van Alst, 2010). Verder blijkt dat meisjes de voordelen van extra-curriculaire activiteiten anders inschatten dan jongens. Stevenson en Clegg adviseren hoger onderwijsinstellingen om deelname van meisjes aan extra-curriculaire activiteiten te stimuleren en meisjes bewust moeten maken van het belang van die activiteiten voor de toekomstige positie op de arbeidsmarkt (Stevenson en Clegg, 2012). De vele activiteiten die gericht zijn op werving van meisjes voor techniek en jongens voor de pabo's zijn hier niet besproken omdat ze niet gericht zijn op het verbeteren van studiesucces van de onderscheiden groepen.

Er is een rijke literatuur over het laatste mechanisme'perceptie van kosten en baten van studeren'. Het blijkt dat zowel de werkelijke als de gepercipieerde baten en lasten voor jongens en meisjes verschillen en dat dit een invloed heeft op studiekeuze en studiesucces. De traditionele economische benadering en 'behavioral economics' geven aan dat vrouwen minder baten hebben, die baten lager inschatten en daardoor minder vaak voor hoger onderwijs kiezen en vaker zullen uitvallen. Er zijn echter tal van alternatieve benaderingen, die veelal een bredere niet-financiële blik op kosten en baten hebben. Die benaderingen kunnen voor een deel verklaren waarom, ondanks de voor vrouwen negatieve balans tussen financiële kosten en baten, vrouwen toch succesvoller zijn dan mannen. Beleidsinstrumenten gericht op het verkleinen van de genderongelijkheid in 
studiesucces zijn we niet tegengekomen. De omvangrijke literatuur over het gebruik van financiële prikkels om studiegedrag te beïnvloeden herbergt weliswaar een aantal publicaties over de stimulering van deelname van specifieke doelgroepen, maar vrouwen c.q. mannen worden daarbij niet als specifieke groep onderkend.

De verwevenheid en complexiteit van de invloed van gender op studiesucces en de invloed die leeftijd daarbij speelt sluiten aan bij de dynamische benadering die in het volgende hoofdstuk wordt gehanteerd. De ontwikkeling van het brein is geen deterministisch proces, maar aard en snelheid van de ontwikkeling is mede afhankelijk van omgevingsinvloeden. Invloeden die ook in de beschrijving en duiding van de mechanismen en contexten in het onderhavige hoofdstuk van cruciaal belang zijn gebleken.

\section{BELEIDSAANBEVELINGEN}

- Sociale integratie is een cruciaal mechanisme. Studenten die zich thuis voelen in de (peer) groep en zich thuis voelen in de instelling zijn meer betrokken en presteren daardoor beter. Twee aspecten van de leeromgeving zijn van belang voor de integratie: het onderwijsmodel en de samenstelling van de groep.

- Studentgerichte modellen kunnen een negatieve impact hebben op de prestaties van jongens, maar ook hier geldt dat dit niet (in dezelfde mate) voor alle jongens geldt. Als blijkt dat een brede invoering van dit soort modellen voor andere groepen andere effecten heeft dan is opportuun om het gebruik van een mix met andere instrumenten (zoals meer manvriendelijke curriculum elementen) te onderzoeken.

- Bij het samenstellen van een evenwichtige groep moet niet alleen naar geslacht worden gekeken, maar zijn ook andere onderscheiden (klasse, etniciteit, leeftijd) van belang. Welke scheidslijn dominant is/moet zijn hangt af van de context.

- Grote inzet in termen van aanwezigheid bij contacturen heeft een positieve invloed op de prestaties. Beleidsmatige aandacht voor contacturen lijkt daarom legitiem. Daarbij moet echter wel in de gaten worden gehouden of er geen verschillen zijn tussen groepen studenten voor wat betreft de aanwezigheid bij deelname tijdens contacturen. In het kader van de discours over laddism/'uncool to work'zouden vooral jongens hier een steek kunnen laten vallen. Informatie over studeergedrag van verschillende groepen is in dit licht van belang om de mogelijke effectiviteit van het verhogen van contacturen te kunnen vaststellen. 


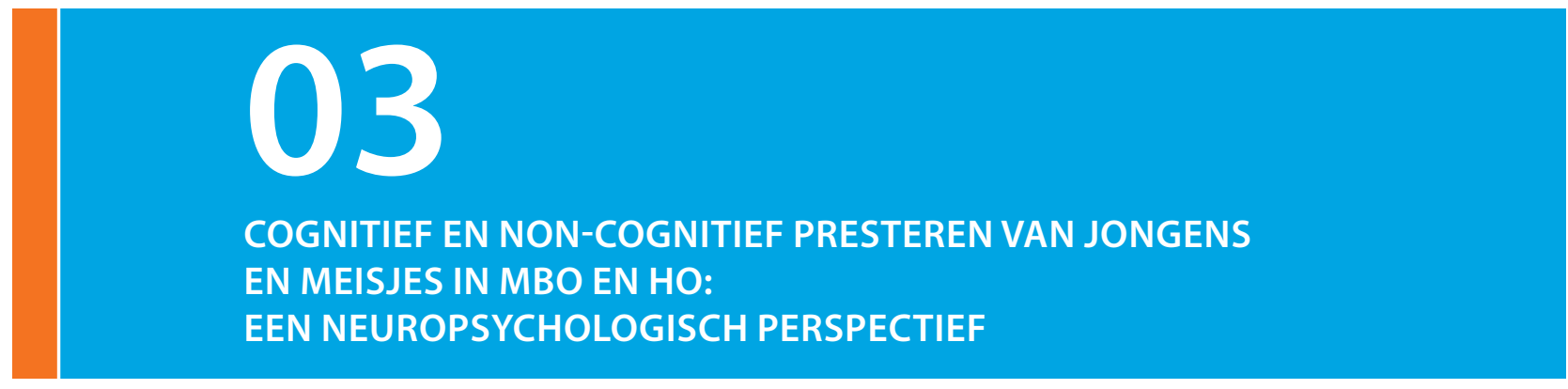

Jelle Jolles en Judith Keizer

(Centrum Brein \& Leren, Vrije Universiteit Amsterdam)

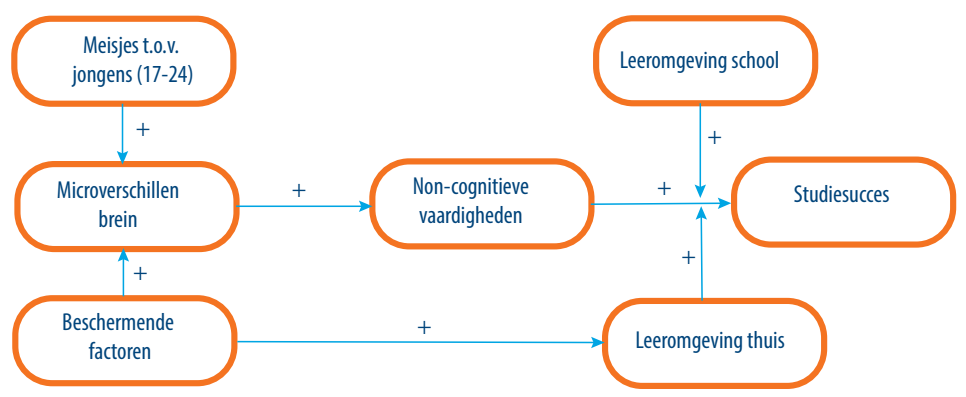

Samenvatting

Dit hoofdstuk bespreekt jongens-meisjes verschillen in neuropsychologisch perspectief, voor zover relevant om sekseverschillen in studieprestatie en leermotivatie te kunnen begrijpen. De bespreking spitst zich toe op de periode van de late adolescentie (circa 17 tot 22 jaar) en het mbo en ho. Uitgangspunt is dat zowel neuropsychologische factoren, hersenontwikkeling, cognitieve en sociaal-culturele factoren belangrijk zijn om deze verschillen te begrijpen. Daarnaast is het van groot belang om jongens-meisjes verschillen te bespreken in ontwikkelingsperspectief: er zijn grote verschillen tussen kinderen en jeugdigen in het tijdpad en en de dynamiek volgens welke de veranderingen zich voltrekken over de lange periode van kindertijd en adolescentie.

Het hoofdstuk start met enkele paragrafen waarin wordt ingegaan op het proces van volwassen worden: 'adolescere'. De adolescentie loopt door tot ongeveer het $25^{\mathrm{e}}$ jaar. Grote individuele verschillen in cognitieve, psychologische en sociale ontwikkeling worden bepaald door zowel de hersenrijping als door omgevingsfactoren. Sekseverschillen in studieprestaties en de cognitieve en non-cognitieve functies kunnen daarom alleen goed beoordeeld worden door dat te doen vanuit een ontwikkelingsperspectief. De grote veranderingen die bijna iedere laat-adolescent doormaakt staan daarin centraal. 
Vanuit een multidimensioneel perspectief wordt gesteld dat verschillen tussen jongens en meisjes in studieprestaties en leermotivatie niet statisch zijn maar dynamisch. Ze zijn veranderbaar en lenen zich voor interventie: voor steun, maar ook sturing en inspiratie. Dat komt door de intensieve samenhang tussen biologische factoren zoals genen, hersenen, hormonen en de omgeving (gezin, buurt, sociale en culturele factoren). Dergelijke inzichten hebben impact voor onderwijsinnovaties die gericht zijn op het maximaliseren van de ontwikkeling van het talent van jongens én van meisjes.

Het hoofdstuk sluit af met een bespreking van mogelijke implicaties voor de onderwijspraktijk. Betoogd dat de talentontwikkeling van jongens en van meisjes multidimensioneel bepaald is. Dat betekent dat een aanpak alleen kan werken als de verschillende factoren of dimensies worden meegewogen: vaardigheden, beleving en gedrag van een jongen (of meisje) van 17 jaar worden niet alleen door biologische verschillen tussen de seksen bepaald maar ook door de persoonlijke biografie: door wat de adolescent eerder in het leven aan ervaringen heeft opgedaan, door de attitude die hij of zij heeft ontwikkeld en door de omgeving waarin hij of zij is opgegroeid. In deze zin zijn sociale en culturele factoren erg belangrijk. In de wijze waarop we met jongens en met meisjes omgaan en via de verwachtingen die we aan hen stellen. Hoopvol aan een multidimensioneel model van jongens-meisjesverschillen is dat het laat zien dat gedrag, vaardigheden, beleving, prestaties, motivatie en attitude niet statisch zijn maar veranderbaar. Het is de omgeving die de faciliteiten kan bieden aan de zich ontwikkelende adolescent en hem of haar de steun, de sturing en de inspiratie bieden om de potenties, de talenten optimaal ontplooiing te brengen. Dát is de uitdaging voor ons onderwijs.

\subsection{Inleiding}

\subsubsection{Het probleem}

Waardoor worden de studieprestaties en leermotivatie van jongens en meisjes bepaald? Zijn er oorzaken aan te wijzen voor de groter wordende kloof tussen jongens en meisjes in beroeps- en voortgezet onderwijs en in het hoger onderwijs? Verschillen ze in hun cognitief functioneren? En áls zulke verschillen bestaan, hangen deze dan samen met de biologie dan wel met de omgeving, dus met psychosociale of culturele factoren? Het is van maatschappelijk belang om meer zicht te krijgen op de samenhang van biologische en omgevingsfactoren en hun relatie tot studieprestaties en leermotivatie. Dergelijk inzicht kan bijdragen aan maatregelen om de talentontwikkeling van jongens én meisjes - mannen én vrouwen - te vergroten.

Tot in de jaren ' 80 van de vorige eeuw deden jongens het wat beter in het onderwijs. Ze presteerden beter in rekenen en wiskunde dan meisjes (Wai et al, 2010 in Miller en Halpern 2014). Ook waren er relatief gezien wat meer jongens die slaagden voor hun eindexamen en er gingen meer jongens studeren (zie elders in dit rapport). Jongens waren ook in diverse studierichtingen oververtegenwoordigd, met name in de exacte wetenschappen en de geneeskunde. De actie'Marie, wordt wijzer!' in de jaren ' 80 beoogde dan 
ook om de onderwijsdeelname van meisjes te vergroten zodat hun kansen in de samenleving zouden groeien. Sindsdien zijn de sekseverschillen in leren en studieprestaties snel kleiner geworden (Hedges en Nowell, 1995 en Hyde et al., 1990) en tegenwoordig doen meisjes het op veel domeinen beter dan jongens. Zowel in het voortgezet onderwijs als in het hoger onderwijs worden meisjes gekenmerkt door betere prestaties, door minder uitval en kortere studieduur.

'Marie is wijzer geworden, maar hoe zit het met Paul en Achmed?' is dan ook de vraag (Jolles, 2011, Engbers, 2012). Welke factoren zijn bepalend voor de jongens-meisjes verschillen in studieprestaties en leermotivatie en in hun onderwijsparticipatie? Sociaalculturele factoren spelen daarin een belangrijke rol, zoveel is in afgelopen decennia wel duidelijk geworden. Tot voor kort werden aan meisjes vaak minder, of in ieder geval andere eisen gesteld. En hun gedrag en studiekeuzen zijn daar zeker door bepaald (Hyde, 2014). Minder duidelijk was tot nu toe dat ook neurocognitieve vaardigheden, andere neuropsychologische factoren en de rijping van de hersenen relevant kunnen zijn. Daar gaat dit hoofdstuk op in. Recente wetenschappelijke inzichten worden besproken die van belang kunnen zijn om jongens-meisjes verschillen beter te kunnen begrijpen. Er is een toespitsing gemaakt op de late adolescentie, dat wil zeggen de periode vanaf ongeveer 17 jaar tot ruim na het $22^{\mathrm{e}}$ jaar.

\subsubsection{De overgang van voortgezet naar hoger onderwijs: een turbulente periode}

De overgang van de middelbare school naar het hoger onderwijs heeft voor de meeste studenten een grote impact door de vele veranderingen in hun mogelijkheden, beleving en sociale relaties. Dat geldt voor vwo-ers die naar de universiteit of hogeschool gaan, maar ook voor mbo-ers en havisten die beginnen met een studie aan een hogeschool of die gaan werken. Velen hebben hoge verwachtingen van de nieuw intredende levensfase en hebben de overtuiging 'World, Here I Come' en 'eindelijk vrij'. Veel jonge studenten hebben echter ook wel wat zorgen omdat de context waarin ze functioneren verandert. Daarmee worden hun taken en verantwoordelijkheden zwaarder (Lowe en Cook 2003, Casey, Duhoux en Malter Cohen, 2010). Het onderwijssysteem op de universiteit of hogeschool lijkt niet op wat de student gewend is van de middelbare school. De student is plotseling heel vrij en wordt geconfronteerd met een andere studieaanpak en ander leermateriaal. Tegelijkertijd wordt van hen verwacht dat ze zelfstandig kunnen zijn, goed kunnen kiezen, en zich op een verantwoorde en betrokken manier kunnen richten op hun studie. Het probleem voor de laat-adolescent is nog groter omdat deze periode niet alleen wordt gekenmerkt door grote veranderingen in onderwijsaanpak en studieaanpak maar ook vinden er veranderingen plaats in de leefomgeving. Het venster op de wereld gaat voor ze open. Na de schooltijd verlaten veel studenten het ouderlijk huis, gaan elders wonen, ontmoeten veel mensen en maken nieuwe vrienden. Ze verliezen de contacten uit kinder- en schooltijd en worden ingebed in nieuwe en snel veranderende sociale netwerken. Tevens worden ze financieel en sociaal onafhankelijk. En dat kan weer zorgen opleveren: de student heeft nog maar weinig ervaring in de organisatie van het eigen leven, in het beheer van financiën en zelfs in de korte termijn planning en prioritering ('zal ik vanavond dat werkcollege voor morgen voorbereiden of ga 
ik eerst met mijn vrienden uit?'). En wat hier is beschreven voor de student in het hoger onderwijs geldt vice versa ook voor die jongeren die na hun middelbare school niet gaan studeren maar gaan werken. Ook voor hen geldt dat de leef- en werkwereld sterk verandert en een beroep doet op vaardigheden en ervaringen die ze in de schooltijd gewoonlijk nog niet verworven hebben.

Ook zijn er grote veranderingen in de fysieke, psychologische en persoonlijke ontwikkeling in de late adolescentie (Dahl 2004, Steinberg en Morris 2001, zie ook Steinberg, 2014). Zo toont recent wetenschappelijk onderzoek aan dat de hersenrijping en de daarmee samenhangende ontwikkeling van neuropsychologische vaardigheden nog doorloopt tot het $25^{\mathrm{e}}$ jaar (zie Steinberg, 2014). Ook zijn er sterke aanwijzingen dat jongens - in vergelijking met meisjes - gemiddeld wel 1-2 jaar achterlopen in bepaalde aspecten van de neuropsychologische ontwikkeling (Lenroot en Giedd, 2010). Daarbij gaat het om vaardigheden die juist belangrijk zijn voor het zelfstandig vormgeven van het eigen leven en voor een effectieve studieaanpak. Middelbare scholieren in de eindexamenjaren en veel jonge studenten zijn tussen de 16 en 20 jaar en zitten biologisch gezien in de fase van de late adolescentie (Dahl, 2004; Steinberg 2014; Veroude, Jolles et al. 2013a, b). Dat is de periode die ook wel beschreven wordt als 'emerging adulthood' (ofwel de start van de volwassenheid, doorlopend tot ruim na het $20^{\mathrm{e}}$ jaar; Arnett 2000). Het is daarom goed voorstelbaar dat verschillen in de studieprestaties en leermotivatie van jongens en meisjes samenhangen met hun cognitieve en neuropsychologische ontwikkeling. Die ontwikkeling is zelf mede gebaseerd op de complexe interactie tussen prikkels uit de omgeving - zoals de steun en sturing van ouders - en de hersenrijping. Dit hoofdstuk bespreekt de wetenschappelijke evidentie daarvoor en de mogelijke consequenties.

\subsubsection{Doel, aanpak}

In dit hoofdstuk worden visies en recente literatuur besproken die relevant kunnen zijn om de jongens-meisjes verschillen in studieprestaties maar ook in leermotivatie beter te begrijpen. Het gaat om de levensperiode van de late adolescentie zoals die tot uiting kan komen bij scholieren op het mbo, maar ook van toepassing is op jonge studenten in het hoger onderwijs (met een vooropleiding in mbo, havo of vwo). Het hoofdstuk is geschreven vanuit de overtuiging dat zowel biologische factoren als psychosociale en culturele factoren belangrijk zijn: het gaat om een multidimensioneel probleem. Daarom wordt hier betoogd dat de jongens-meisjes verschillen niet los gezien kunnen worden van de enorme ontwikkeling die de laat-adolescent nog doormaakt. Die ontwikkeling gaat om zowel cognitieve als non-cognitieve vaardigheden als om biologischeen hersenontwikkeling en om de ervaringen die worden opgedaan. Tevens gaat het om de grote veranderingen in de persoonlijke groei: in beleving, attitude en het sociaal en psychologisch functioneren. Om verschillen tussen jongens en meisjes in de late adolescentie en vroege volwassenheid te kunnen begrijpen moet dus ingegaan worden op die multidimensionele ontwikkeling. De volgende paragraaf is daarom gewijd aan de adolescentie (par 3.2), waarna wordt ingegaan op jongens-meisjes verschillen in het cognitief functioneren (par 3.3), en in het psychologisch functioneren (par 3.4). Het 
hoofdstuk wordt afgesloten met een bespreking van de samenhang van die invalshoeken en de mogelijke consequenties in de omgang met jongens dan wel meisjes in het onderwijs (par 3.6).

\subsubsection{Pretenties}

Het hoofdstuk is te beschouwen als een opiniehoofdstuk dat zich baseert op uitgebreid literatuuronderzoek en 20 jaar wetenschappelijk onderzoek in de onderzoeksgroep van de hoofdauteur van dit hoofdstuk. Het beoogt een samenhangende visie te beschrijven die waarde kan hebben voor het overheidsbeleid rond onderwijs en onderwijsinnovatie en voor de onderwijspraktijk. De nadruk ligt bij een bespreking van recent onderzoek omdat nieuwe wetenschappelijke bevindingen suggereren dat eerder onderzoek moet worden herzien. De auteurs Miller en Halpern hebben het in hun review uit 2014 dan ook over 'The new science of cognitive sex differences' (Miller en Halpern, 2014). Zij betogen dat veel van het eerder uitgevoerde en in de literatuur gerapporteerde onderzoek geen grote bijdrage kan leveren aan een beter begrip over de (achtergronden van) jongens-meisjesverschillen.

Voorliggend hoofdstuk maakt vooral gebruik van onderzoek dat de laatste drie jaar is gepubliceerd in wetenschappelijke toptijdschriften in zowel de gedragswetenschap als in de neuro- en cognitieve psychologie en de neurowetenschappen. De lezer die geïnteresseerd is om zich dieper in te lezen in recente overzichtsartikelen wordt verwezen naar Miller en Halpern (2014), Hyde (2014 ), Lenroot en Giedd (2010), Rindermann en Baumeister (2015) en Diamond (2013). Deze reviews belichten de diverse dimensies (cognitieve, biopsychologische, sociaal wetenschappeliljke en neuropsychologische aspecten) en zijn daarin complementair aan elkaar. Het hoofdstuk werkt toe naar de volgende kernstelling: Verschillen tussen jongens en meisjes in studieprestaties en leermotivatie zijn niet statisch maar dynamisch. Ze veranderen in de tijd en lenen zich voor interventie: voor steun, maar ook sturing en inspiratie vanuit de sociale omgeving. Dat komt door de intensieve samenhang tussen biologische factoren (genen, hersenen, hormonen) en de omgeving (gezin, buurt, sociale en culturele factoren; Jolles 2011, Jolles 2015).

Alvorens de jongens-meisjes verschillen op gebied van cognitie, neuropsychologie en psychologie te beschrijven, gaat het in de volgende paragraaf over de late adolescentie. Dit is een kernparagraaf in dit overzichtshoofdstuk omdat jongens-meisjes verschillen zoals die zich uiten in hun vaardigheden, gedrag en beleving - sterk tot expressie komen in de sociale omgeving van de adolescent. Beter begrijpen van 'de adolescentie' is van belang om ook de biopsychologische en psychosociale basis van jongens-meisjes verschillen beter te kunnen begrijpen. 


\subsection{Over de Adolescentie}

\subsubsection{Begripsverheldering}

Het begrip 'Adolescentie' stamt af van adolescere uit het Latijn, wat 'volwassen worden' betekent. De adolescentie wordt gezien als de fase tussen het begin van seksuele rijping (puberteit) en de volwassenheid. Het is een tijd waarin iemand psychologisch en sociaal volwassen wordt. Het woord 'puberteit' wordt vaak verkeerd gebruikt en heeft eigenlijk alleen betrekking op de periode van lichamelijke ontwikkeling. Deze periode speelt zich af in het eerste deel van de adolescentie, tot ca 14 à 15 jaar. Volgens Steinberg (2014) een erkend autoriteit op gebied van de adolescentie - gaat het bij de adolescentie om een fase die doorloopt tot ongeveer 25 jaar waarin de hersenen bijzonder plastisch zijn. De hersenrijping wordt in deze periode gekenmerkt door een sterke ontwikkeling van interne verbindingen en hersennetwerken. Bestaande netwerken worden over een periode van jaren véél complexer en omvangrijker. Het zijn de ervaringen die de adolescent opdoet die daar verantwoordelijk voor zijn. Tegelijk zijn de hersennetwerken en clusters van hersencellen waar deze uit bestaan zeer gevoelig voor invloeden vanuit de fysieke en sociale omgeving.

Steinberg beschouwt de adolescentie als een periode van grote mogelijkheden voor ontplooiing en heeft het dan ook over 'The age of opportunity' (zie ook Dahl, 2004). Doordat de hersenen (lees: de hersennetwerken) van de adolescent bijzonder plastisch - veranderbaar - zijn, is de adolescent erg ontvankelijk voor het opdoen van nieuwe ervaringen en voor sociaal leren. Maar is hij in deze periode ook behoorlijk kwetsbaar. Veel psychologische stoornissen doen zich dan ook voor het eerst voor tijdens de adolescentie. In box 3.1 wordt het begrip adolescent verhelderd.

\section{TEKSTBOX 3.1 Begripsverduidelijking 'Late adolescentie'}

\section{Verwarring omtrent het begrip 'adolescent'.}

Het begrip adolescent wordt vaak verward met de begrippen jongere, puber of tiener. Wanneer iemand vertelt over zijn of haar opgroeiende tiener die zo moeilijk doet, risico's neemt, niet luistert en last heeft van 'razende hormonen' worden er twee processen door elkaar gehaald; het proces van psychologische en sociale volwassenwording en het proces van biologische rijping. In de wetenschappelijke literatuur wordt in toenemende mate het begrip 'adolescent' gebruikt in plaats van 'jongere', 'tiener' of 'puber' omdat dit het zeer langdurige proces van volwassen worden het beste beschrijft. Steeds meer wordt erkend dat de adolescentie doorloopt tot circa 22 of zelfs 25 jaar (zie Steinberg, 2014 en andere publicaties) en zich dus uitstrekt over een veel langere periode dan puberteit en tienertijd. 


\section{Het begrip'puberteit'.}

De puberteit is de tijd waarin iemand seksueel en fysiek volwassen wordt. Het woord puberteit komt van het Latijnse woord pubescere wat 'haargroei krijgen' betekent (Brooks-Gunn en Petersen, 1984). Dit verwijst naar de ontwikkeling van schaamhaar, haar onder de oksels en op de benen. De puberteit begint onder invloed van hormonen in het lichaam. De leeftijd waarop dit gebeurt verschilt tussen jongens en meisjes; meisjes raken over het algemeen één a twee jaar eerder in de puberteit. In de afgelopen tientallen jaren is de leeftijd dat de puberteit begint verschoven naar jongere leeftijd. De puberteit valt ongeveer samen met de periode van 'de vroege adolescentie' (zie beneden).

\section{De leeftijden van de adolescentiefase.}

De laatste jaren wordt herkend dat de adolescentie langer doorloopt dan vroeger, en wel van circa 10 à 12 jaar tot circa 25 jaar. Binnen de adolescentie wordt gewoonlijk een onderscheid gemaakt tussen verschillende fases. De vroege adolescentie (10 à 12 tot 14 jaar), de midden adolescentie (15 à 16 jaar) en de late adolescentie ( 16 à 17 tot 19 à 22 jaar). Voor het aanduiden van de overgang van adolescentie naar volwassenheid (ca 19-25 jaar) wordt regelmatig het begrip emerging adulthood, 'start van de volwassenheid' gebruikt.

\section{De periode rond de opkomende volwassenheid.}

De periode van emerging adulthood loopt ongeveer van 18 tot 25 jaar. Het is een periode waarin men niet meer van de ouders afhankelijk is zoals in de kindertijd en tienerjaren, maar die nog niet gekenmerkt wordt door alle verantwoordelijkheden die bij de volwassenheid horen. Emerging adults ontdekken vaak veel nieuwe dingen in het leven op het gebied van liefde, werk en visie op de wereld. Veel keuzes voor de toekomst staan nog niet vast en daarom is het hen mogelijk om te ontdekken wat voor verschillende mogelijkheden het leven biedt.

\subsubsection{Kiezen en beslissen bij de laat-adolescent}

Tijdens de late adolescentie maken mensen keuzes die belangrijk zijn voor de rest van hun leven (Zarret en Eccles, 2006) zoals de keuze voor een vervolgopleiding en de beslissing het ouderlijk huis te verlaten. Sommige laat-adolescenten betreden de arbeidsmarkt. Er zijn adolescenten die al op jonge leeftijd trouwen en/of kinderen krijgen. Deze sociale veranderingen zorgen ervoor dat het gaat om een kwetsbare periode. Steinberg (2014) en anderen menen dat er meer dan vroeger sprake is van een verlengde overgangsperiode van de adolescentie naar volwassenheid. Dat heeft te maken met de samenleving die veel complexer is geworden, de sterk veranderde sociale relaties binnen gezin en familie, de opkomst van internet en de nieuwe media en grote culturele en politieke veranderingen die te maken hebben met migratie en andere samenstelling van de bevolking. Dit geldt voor vrijwel alle westerse landen. Daarom zijn veel 'emerging adults' tegenwoordig nog niet klaar voor de zelfstandigheid die op grond van hun leeftijd van hen verwacht wordt. Enkele decennia geleden waren de rollen van scholier en student enerzijds en die van hun onderwijzers en onderwijssysteem anderzijds veel duidelijker. Er was meer structuur en voor de scholier en voor de student was het duidelijker wat er van hen wanneer werd verwacht. 
De discrepantie tussen enerzijds de reeds opgedane levenservaring van de adolescent en anderzijds de complexiteit van de moderne samenleving is de hoofdreden waarom het voor veel laat-adolescenten zo moeilijk is om hun studie te plannen en verantwoordelijkheid te nemen voor het eigen leerproces. De complexe samenleving vereist - in vergelijking tot de periode vanaf 1945 tot ongeveer 1980 - dat meer ervaringen worden opgedaan en dat meer vaardigheden en voldoende toegespitste skills worden ontwikkeld. Dat is nodig om succesvol aan het maatschappelijk verkeer deel te kunnen nemen en zich zelfstandig daarin verder te kunnen ontwikkelen.

De vele keuzen die in het sociaal verkeer gemaakt kunnen worden maken de studieconcentratie er niet makkelijker op. Een avondje uit met vrienden of toch een goede nachtrust nemen om morgen goed te kunnen leren? De toets voorbereiden, dat uitgestelde telefoontje plegen of boodschappen doen nu de supermarkt nog open is? Het zijn de dagelijkse dilemma's van de laat-adolescent en de jongvolwassene. Hun vaardigheid in plannen en prioriteren ontwikkelt zich nog volgens patronen die in volgende paragrafen wordt toegelicht. Dat komt ook omdat de meeste laat-adolescenten in kinder- en tienertijd nog niet de ervaringen hebben kunnen opdoen die nodig zijn om de consequenties van het eigen handelen te kunnen herkennen. Het feit dat ze zich neuropsychologisch nog ontwikkelen en ook nog te weinig ervaring hebben zorgt dat ze bij het nemen van beslissingen extra gevoelig zijn voor prikkels uit de omgeving. Dus sociale en emotionele factoren zijn voor hen erg belangrijk. En dat maakt dat deze levensfase waarin juist keuzes gemaakt moeten worden er één is van mogelijkheden ('opportunities') maar ook van bedreigingen. De laat-adolescent maakt al gauw keuzen die grote consequenties kunnen hebben voor de rest van het leven.

\subsubsection{Zelfinzicht}

Laat-adolescenten ontwikkelen vaardigheden in het evalueren van zichzelf en van doelen, aanpak en mogelijke consequenties van het eigen gedrag: 'wat zal ik doen?', 'heb ik dat goed aangepakt?', 'waarom werkte dat nou niet?' (zie tabel 3.1) (Albert en Steinberg, 2011). Ook worden ze in vergelijking met kinderen en jong-adolescenten veel beter in het oplossen van strategische problemen en in het flexibel gebruiken van regels. Ze kunnen steeds beter vooruitkijken en plannen 'als ik de komende twee weken een uur per dag aan dat vak zit, ben ik klaar en kan ik daarna een week aan de scriptie werken'. Ook ontwikkelen ze metacognitieve vaardigheden. Daarbij gaat het om de vaardigheid in het reflecteren op de eigen gedachten, belevingen en gedrag 'het was misschien niet zo handig om gisteravond nog naar de kroeg te gaan; ik ben nu brak', 'hmm, ik merk dat ik niet te popie-jopie moet doen naar die docent. Ook de impulscontrole ontwikkelt zich gedurende de hele adolescentie tot in het begin van de volwassenheid. Daarmee neemt de neiging af om te kiezen voor onmiddellijke behoeftebevrediging en wordt steeds meer gekozen voor zaken die zich op ietsje langere termijn zullen opleveren. Als voorbeeld: 'Als ik komende twee weken nou eens zorg dat ik op tijd naar bed ga en niet teveel alcohol drink, dan kan ik me komende weken beter concentreren en ben ik fit voor de tentamenweek die direct daarop volgt'. 
In de adolescentie ontwikkelt zich ook het vermogen om sociale en emotionele invloeden te weerstaan. Daarmee is de adolescent ook beter in staat om weerstand te bieden tegen groepsdruk vanuit leeftijdsgenoten. Echter, juist in de late adolescentie bestaan grote verschillen tussen individuele personen. De meeste meisjes zijn iets vaardiger in zelfreflectie dan de meeste jongens. Maar ook binnen de groep van meisjes en die van de jongens bestaan heel grote verschillen. Het is een fascinerende gedachte dat de jongens-meisjes verschillen mede bepaald zouden kunnen zijn door het feit dat de adolescent van 16-18 jaar nog niet klaar is, en zelfs dat de adolescentie voor veel jongeren wel doorloopt tot ver na het $20 e$ jaar. Voor het onderwijs heeft dit als mogelijke consequentie dat jongeren (jongens én meisjes) de mogelijkheid moeten krijgen om langer door te kunnen rijpen. Dat betekent dat de samenleving er niet van moet uit gaan dat ze al op hun $18 \mathrm{e}$ - juridisch meerderjarig - ook in sociale en psychologische zin alle vaardigheden bezitten die nodig zijn voor hun participatie aan de samenleving.

TABEL 3.1 Overzicht non-cognitieve vaardigheden ${ }^{8}$

\begin{tabular}{l|l|}
\hline Vaardigheden & Waar gaat het om? \\
\hline Strategische problemen oplossen & $\begin{array}{l}\text { Het oplossen van complexe problemen waarvoor meerdere denkstappen en planning } \\
\text { vereist zijn }\end{array}$ \\
\hline Cogruit kijken, plannen & $\begin{array}{l}\text { Structuur aanbrengen in, en prioriteren van taken die de persoon wil of moet uitvoeren } \\
\text { Het kunnen aanpassen van je plannen, gedachten en gedrag als de omstandigheden } \\
\text { veranderen }\end{array}$ \\
\hline Metacognitie & De vaardigheid van het kunnen reflecteren op de eigen gedachten \\
\hline Impulscontrole & $\begin{array}{l}\text { De vaardigheid om onmiddellijke beloningen te kunnen uitstellen en niet direct te } \\
\text { handelen of reageren maar pas na een zekere reflectie }\end{array}$ \\
\hline Empathie & $\begin{array}{l}\text { De vaardigheid om in te schatten wat iemand anders denkt of voelt, zich kunnen } \\
\text { verplaatsen in de ander en zich aldus het gedrag en beleving van de ander te kunnen } \\
\text { voorstellen. }\end{array}$ \\
\hline
\end{tabular}

\subsubsection{Non-cognitieve vaardigheden}

Om de middelbare school succesvol te kunnen doorlopen zijn zowel cognitieve vaardigheden als non-cognitieve vaardigheden nodig (OECD, 2015a, b). Cognitieve vaardigheden worden gemeten door middel van tests zoals IQ-tests en met cognitieve taken zoals in gebruik zijn bij (neuro)psychologen. Om prestaties op school te kunnen neerzetten heb je echter ook de non-cognitieve vaardigheden nodig. Neuropsychologen gebruiken voor deze vaardigheden gewoonlijk de term 'Executieve functies' oftewel de uitvoerende controlefuncties. Deze worden nader besproken in paragraaf 3.3 in relatie tot de rijping van de hersenen. De term 'non-cognitieve functies' wordt sinds 2014 steeds vaker gebruikt in het domein onderwijs, sinds de OESO er een rapport aan heeft gewijd (OECD, 2015a, b).

$8 \quad$ Er is een grote overlap tussen de non-cognitieve vaardigheden en datgene wat door neuropsychologen wordt omschreven in termen van 'Executieve functies' (EF). De terminologie is niet heel helder, en experts verschillen in wat zij onder de EF scharen. Om pragmatische redenen wordt voor dit hoofdstuk primair gesproken over de non-cognitieve functies/vaardigheden teneinde aan te sluiten bij rapporten daarover die in afgelopen jaren zijn verschenen voor het domein 'onderwijs'. Zie ook par 3.3. 
De belangrijkste non-cognitieve functies zijn zelfinzicht en motivatie, doelgerichtheid, nieuwsgierigheid en initiatiefname alsmede de z.g.'monitoring' functie. Daarbij gaat het om het vermogen om de intenties en gevoelens van anderen te begrijpen en ook in te kunnen voelen. Zo is empathie de vaardigheid om de mentale staat van anderen in te schatten en als het ware te 'door-leven'. Het wordt daardoor makkelijker om rekening te kunnen houden met gedrag en bedoelingen van iemand anders, die immers ook sterk door diens beleving wordt bepaald. Empathie ontwikkelt zich al vanaf de vroege jeugd, de peutertijd, en dat proces loopt door tot in de volwassenheid. Non-cognitieve vaardigheden zijn nodig om de cognitieve vaardigheden goed tot uiting te laten komen. Zo zal een scholier of student die gemotiveerd is om te leren voor een toets uiteindelijk een betere prestatie gaan leveren dan iemand die niet gemotiveerd is, ook al zijn hun cognitieve vaardigheden gelijk. Goed ontwikkelde non-cognitieve vaardigheden zorgen er dan ook voor dat de scholier of student de juiste prioriteiten stelt en keuzen maakt die hem een hoog rendement opleveren. Een persoon die goed kan kiezen en beslissen, is in staat om verschillende gedragsalternatieven te overwegen. Daarmee kan hij of zij de korte, de middellange termijn en de lange termijn consequenties overzien en aan de hand daarvan de beste keuze maken. Het is evident dat een groot deel van de laatadolescenten in dit proces nog een behoorlijke ontwikkeling te gaan heeft.

\subsubsection{De laat-adolescent, het onderwijs en eerdere levenservaringen}

Veel jonge studenten hebben moeite met de omschakeling van vo naar universiteit/ hogeschool (en van mbo naar hogeschool) omdat er van hen een andere studiehouding en leeraanpak wordt gevraagd. ${ }^{9}$ Het onderwijssysteem gaat er tegenwoordig van uit dat de student zelfstandig moet kunnen werken. Hij of zij heeft zelf gekozen voor zijn studie en voor het leven dat hij of zij leidt en wordt dan ook verwacht 'om de regie te hebben over het eigen leerproces'. Sinds de jaren ' 80 wordt benadrukt dat de student zelf verantwoordelijk is voor de planning van zijn studie en zijn leergedrag. Probleem is dat de fase van de late adolescentie nou net gekenmerkt wordt door gebrek aan levenservaring en nog niet volgroeide cognitieve en noncognitieve vaardigheden zoals in de vorige paragraaf besproken. Er zijn grote verschillen tussen studenten in de mate waarin ze deze ervaringen en vaardigheden verworven hebben. Daarom zijn er bij aanvang van hun studie grote verschillen tussen studenten de zelfstandige studiehouding en in de vaardigheid van het 'zelf regie nemen' die de opleiding van hen vraagt.

In de late adolescentie is de zelfregulatie en het kiezen en beslissen vooral moeilijk in een context waarin sociale relaties en vooral emoties een plek hebben (Casey, Jones en Somerville, 2011). De nieuwe academische omgeving doet een groot beroep op deze vaardigheden omdat er meer vrijheid is dan in het voortgezet onderwijs en beroepsonderwijs. Dit terwijl de laat-adolescent bij uitstek navigeert binnen sociale netwerken waarin het opdoen van nieuwe relaties - met al hun emotionele consequenties - van groot belang is. Een scholier of student die onvoldoende weerstand kan bieden tegen groepsdruk en de emotionele connotaties daarvan ('Hee, watje, moet je nu alweer neuzen

9 Opmerkelijk is dat een dergelijke discontinuïteit ook aanwezig is bij de overgang van basisonderwijs naar het voortgezet onderwijs. Vanwege de focus in voorliggend rapport wordt daar nu niet verder op ingegaan. 
in die boeken?') heeft hoogstwaarschijnlijk ook een minder goede studievoortgang dan er bij zijn talenten hoort. Zo bleek uit onderzoek dat een gebrekkige studievoortgang in het eerste jaar van het ho een goede voorspeller is van het stoppen met de studie in een later jaar (Lowe en Cook, 2003, Baars et al., 2015). Ook zijn er aanwijzingen dat studenten die gekenmerkt zijn door minder goed ontwikkelde non-cognitieve functies ook slechter presteren in de studie dan studenten die het juist goed doen in non-cognitief functioneren (Knouse, Feldman en Blevins, 2014).

\subsubsection{De rol van de sociale achtergrond}

De laatste jaren wordt snel duidelijk dat gezin en familie van de student sterk medebepalend zijn voor studiesucces en leermotivatie. Vooral het opleidingsniveau en het werk van de ouders zijn belangrijk. Deze hebben invloed op de aard en de mate van emotionele en intellectuele stimulering thuis. Het gaat dus om de uitgangssituatie waarmee de student met de studie begint, die feitelijk is bepaald door de mogelijkheden en stimulering in het gezin (Rindermann en Baumeister, 2015). Studenten verschillen enorm van elkaar ten aanzien van ervaringen in kinder- en tienertijd, thuis in het gezin, op school en in hobbies, sport en spel. De mate waarin de thuisomgeving steun en sturing biedt, routes wijst en inspireert over mogelijke keuzen en de consequenties ervan lijkt van een cruciaal belang te zijn. Steinberg (2014) benadrukt het belang van steun uit de familie. Een student die het van huis uit heeft meegekregen om vasthoudend te zijn en taken af te maken, zal meer succes boeken. Naarmate er binnen de familie meer ervaring is met hoger onderwijs en met de zelfstandigheid die binnen het ho gevraagd wordt, is te verwachten dat de student veel meer steun en bruikbare adviezen krijgt dan de eerstegeneratie student.

De thuisomgeving helpt het kind om vele ervaringen op te doen. Daarmee gaat het om sociaal leren en communiceren maar ook om bewegen, ruimtelijke oriëntatie en vele andere cognitieve functies. Daarvoor is de buurt belangrijk en 'het pleintje waar buitengespeeld kan worden', maar ook de sport, ballet of muziekclubs die het kind al dan niet kan volgen. Kind en tiener leren in de sociale omgeving om fouten te maken, opwindende, gevaarlijke, saaie of coole dingen mee te maken. En voor de meeste jongens en de meeste meisjes is de cultuur waarin ze zijn opgegroeid en de wijze waarop er met hun werd omgegaan (c.q. de verwachtingen die aan hen zijn gesteld) in cruciale zin bepalend voor hun gedrag en beleving en voor hun prestaties in relatie tot schools leren en studiegedrag.

In onze samenleving wordt gewoonlijk anders omgegaan met jongens en met meisjes, en wel vanaf vroeg in het leven. Dit heeft een grote invloed op hun psychologische maar ook cognitieve en sociale ontwikkeling, en daarmee moet rekening gehouden worden in iedere discussie over sekseverschillen in cognitief functioneren. Voor deze dimensie van 'hoe er naar jongens c.q. meisjes wordt gekeken' wordt gewoonlijk de term 'gender' gebruikt. In paragraaf 6 wordt ingegaan op gender in relatie tot individuele verschillen. 


\subsubsection{Zelfregulatie als factor in studiesucces}

Succes heeft niet zozeer te maken met intelligentie, maar veeleer met vasthoudendheid: het vermogen om zich te concentreren op een taak en deze vervolgens af te maken (Steinberg, 2014). De term 'zelfregulatie' verwijst naar iets anders dan zelfinzicht; er is nu sprake van een handeling-component, om doen. Zelfregulatie heeft betrekking op 'wat doet de persoon met het zelfinzicht, welke acties vloeien er uit voort'. Ook de zelfregulatie is een functie die zich juist tijdens de late adolescentie én gedurende de jonge volwassenheid nog sterk ontwikkelt. Net zoals dat geldt voor zelfinzicht, flexibiliteit, switchen, inhibitie, empathie, consequenties inschatten, plannen en prioriteren, En er zijn enorme individuele verschillen als het gaat om de timing en het tempo van deze ontwikkeling. Er zijn jongens en meisjes die rond het $18^{\mathrm{e}}$ jaar nog uitgesproken ongeconcentreerd en impulsief zijn en niet handig functioneren in de sociale setting, maar vijf jaar later uitstekend blijken te zijn in plannen en prioriteren en zich ook nog eens heel breed hebben kunnen ontwikkelen. Dit fenomeen wordt mooi beschreven met de metafoor 'Een traag groeiende boom kan zich ontwikkelen tot de hoogste boom' (Jolles, 2011). Als ze niet adequaat worden gestuurd en geïnspireerd, c.q. als hen de routes niet wordt gewezen en ze geen hulp krijgen in de ontwikkeling van de zelfregulatie zullen de prestaties van veel jongeren achterblijven bij hun potentie oftewel talenten. Daar zullen onderwijsinstellingen in het hoger onderwijs rekening mee moeten houden. De onderwijsinstellingen hebben een verantwoordelijkheid om de persoonlijke ontwikkeling van scholier c.q. student. Zij kunnen daarmee een faciliterende rol spelen voor de ontwikkeling van op de vermogens van zelfregulering en kunnen ook rekening te houden met subtiele verschillen die er in die leeftijdsfase nog bestaat tussen jongens en meisjes.

\subsection{Intermezzo: de hersen- en neuropsychologische ontwikkeling in late adolescentie}

Onderzoek van de laatste tientallen jaren laat zien dat bepaalde neuropsychologische functies - ook wel de Executieve Functies (EF, zie Diamond 2013 voor overzicht) oftewel uitvoerende controlefuncties genoemd - zich nog steeds ontwikkelen gedurende de adolescentie. In grote lijnen gaat het bij de Executieve Functies om dezelfde functies die - vanuit een andere invalshoek - omschreven worden als 'non-cognitieve functies' (zie 3.2). Het gaat om zelfinzicht, zelfregulatie, cognitieve flexibiliteit, nieuwsgierigheid, empathie, overzien van de consequenties van keuzen en handelen. ${ }^{\circ}$ De EF zijn nog niet 'klaar' na de puberteit, en rijpen door tot ver in de jonge volwassenheid (Lenroot en Giedd, 2010, Diamond, 2013). Recent onderzoek laat zien dat de EF niet in de adolescentie tot ontwikkeling komen, maar dat het proces al start in de peuter- en kleutertijd. Deze ontwikkeling hangt direct samen met de hersenrijping (Best, Miller en Naglieri, 2011). In box 3.2 wordt nader ingegaan op aspecten van onderzoek naar de ontwikkeling van de hersenen in relatie tot de Executieve Functies (c.q. de non-cognitieve functies)

10 De lezer wordt verwezen naar het uitstekende overzichtshoofdstuk van Diamond (2013) voor een uitvoeriger bespreking van de executieve functies en hun ontwikkeling. 
die relevant zijn om de complexe aard van de verschillen tussen jongens en meisjes beter te kunnen begrijpen.

Tot voor kort is er niet veel onderzoek gedaan naar de hersenrijping van laat-adolescenten en jongvolwassenen. Men ging er vanuit dat de hersenstructuur ergens na de puberteit wel vast zal liggen. Grensverleggend onderzoek met hersenscans dat in 2004 is gepubliceerd (Gogtay et al., 2004) toonde echter aan dat na het $20^{\circ}$ jaar - gemeten over een periode van twee jaar - ook de hersenstructuur nog verandert. Ook met behulp van functioneel hersenimaging onderzoek (zie box 3.2) bleek recentelijk nog een behoorlijke verandering op te treden in de hersenrijping en cognitieve controleprocessen bij laatadolescenten (18-19 jaar) in vergelijking met jonge volwassenen. Dit onderzoek liet zien dat de neurale basis van zelfcontrole verandert tussen de late adolescentie en de jonge volwassenheid. In een ander recent onderzoek werden groepen jongere en oudere adolescenten vergeleken en bleek dat laat-adolescenten beter om kunnen gaan met uitgestelde bevrediging zoals in onze onderzoeksgroep onderzocht (de z.g. 'delayed gratification; Lee, de Groot et al. 2013).

Vertaald naar het domein van leren en studeren heeft het een en ander nogal wat implicaties. De laat-adolescent moet het zelfinzicht krijgen dat hij of zij gedurende enige tijd een investering moet doen in termen van tijd en moeite en dat die inspanningen zich later zullen gaan opleveren. Wat het oplevert is bijvoorbeeld een gehaalde toets maar ook het positieve gevoel van 'ik begrijp die teksten' en zelfs 'hee, geinig onderwerp'. De laat-adolescent heeft al meer zelfinzicht gekregen en realiseert zich gemiddeld genomen al beter hoe de verhouding ligt tussen investering en rendement. Hij kan de aantrekkingskracht van de vele alternatieven beter weerstaan: 'ik moet minimaal 4 uur per dag geconcentreerd achter de boeken zitten en kan dus geen leuke dingen doen'. Maar zelfs veel laat-adolescenten zijn nog niet voldoende ontwikkeld om de leuke dingen uit te stellen tot een (veel) later moment (Christakou, Brammer et al. 2011, Lee, de Groot et al. 2013). 


\section{Hersenrijping}

Dat beslissingen van laat-adolescenten nog niet optimaal zijn (Steinberg, 2014) hangt samen met enorme veranderingen in de hersen-microstructuur. Deze veranderingen starten al voor de geboorte en gaan door tot ver na het 2oe jaar. De macrostructuur van de hersenen is in grote lijnen 'klaar' rond de geboorte. Daarbij gaat het om de positie van de 100 miljard hersencellen - neuronen - en om de uiteindelijke functie die ze zullen krijgen. De z.g. 'microstructuur' van de hersenen ontwikkelt zich echter tot ver na het 20e jaar (de hersenrijping) en blijft zich de hele rest van het leven veranderen ('hersenplasticiteit'). Het zijn met name complexe hersennetwerken die zich ontwikkelen en vanaf de geboorte toenemen in complexiteit. Daarbij worden vele tientallen gebieden met elkaar verbonden: gebieden in de hersenschors, gebieden direct onder de schors, gebieden dieper in het brein die zich bezighouden met de aansturing van het lichaam en gebieden in de hersenstam.

\section{Verbindingsbanen}

De verbindingsbanen tussen hersenstructuren verandert in de loop van kindertijd en adolescentie. Daarbij neemt de z.g.'witte stof' (grof gezegd: de grote verbindingsbanen binnen de hersennetwerken) in omvang toe. Daarentegen nemen de locaties waar vooral de cellichamen van de hersencellen zich bevinden (de 'grijze stof') af in relatieve omvang: ze worden in verhouding wat kleiner. Een belangrijke prikkel voor de ontwikkeling van de microstructuur van de hersenen bestaat uit zintuigelijke input, emotionele input en de terugkoppeling vanuit het lichaam naar de hersenen. Er wordt dan ook wel gezegd 'Context shapes the brain'. Dat wil zeggen dat het de omgeving is die het functioneren van de hersenen bepaalt. Dat hangt samen met de microstructuur van de hersenen die steeds verandert door de opgedane ervaringen (Jolles 2014).

\section{Selectieve rijping}

Veel recent onderzoek naar hersenfuncties en de adolescentie maakt gebruik van hersen-imagingstudies (MRI onderzoek). Grote veranderingen in neuropsychologisch functioneren, gevoelens, sociale cognities en gedrag blijken een directe relatie te hebben met de rijping van de onderliggende hersengebieden en -structuren (Steinberg en Morris 2001, Casey, Jones en Somerville 2011, Diamond 2013). Sommige hersennetwerken ontwikkelen zich al vroeg in de jeugd terwijl andere op dat moment nog nauwelijks actief zijn. Hersennetwerken die nodig zijn voor de zintuigelijke waarneming en voor aansturing van motoriek en het handelen ontwikkelen zich vrij vroeg. Andere, die juist nodig zijn voor de non-cognitieve functies en met name het zelfinzicht, de zelfregulatie en verwante Executieve Functies ontwikkelen zich veel later. Belangrijke gebieden binnen de prefrontale cortex (PFC) blijken mét hun verbindingsbanen naar vele andere hersengebieden nog steeds uit te rijpen in adolescenten en opkomende volwassenen (leeftijd 18-25 jaar). Hetzelfde geldt voor structuren in de parietale schors (achterin de hersenen) en in enkele andere structuren (Shaw, Kabani et al. 2008, Giedd en Rapoport 2010). 


\section{Hersenen, kiezen en beslissen}

Voor de ontwikkeling van zelfinzicht en zelfregulatie bij de laat-adolescent zijn twee hersensystemen met name belangrijk. In de eerste plaats gaat het om deelgebieden binnen de prefrontale cortex. Deze zijn - ingebed in netwerken die de hersenen omspannen - verantwoordelijk voor de zelfregulatie. Daarvoor maken ze via bovengenoemde netwerken gebruik van informatie die is opgeslagen op heel andere locaties in de hersenen. In de tweede plaats gaat het om netwerken waarin kernstructuren uit het limbische systeem zijn opgenomen. Deze zijn betrokken bij de regulering van emoties en ook bij processen rond empathie. De afgelopen tien jaar is veel onderzoek gericht geweest op de relatieve ontwikkeling van deze twee complexe systemen (zie Crone en Dahl 2014 voor nadere bespreking). De rijping van deze twee systemen blijkt niet gelijk te lopen: de netwerken met belangrijke input uit het limbische systeem zijn eerder uitgerijpt, mogelijk al in de laat-adolescentie. Structuren binnen de prefrontale cortex en hun verbindingen rijpen gewoonlijk uit tot ver in de volwassenheid. De discrepantie in de ontwikkeling van de diverse hersenstructuren en de netwerken waarin ze zijn opgenomen heeft vooral invloed op beslissingen die snel genomen moeten worden. Adolescenten van rond de zestien zijn hierdoor ook extra gevoelig voor de belonende waarde van gebeurtenissen en voor een meer directe behoeftenbevrediging.

\subsection{Over jongens-meisjes verschillen in de biopsychologische ontwikkeling ${ }^{11}$}

\subsubsection{De ontwikkeling van verschillen tussen jongens en meisjes: discussiepunten}

Als het gaat om de ontwikkeling van zelfinzicht en zelfregulatie worden naast een effect van leeftijd ook verschillen tussen mannen en vrouwen verwacht. Bij vrouwen ontwikkelt (de connecties tussen) belangrijke structuren zich gemiddeld wat eerder dan bij mannen (Lenroot en Giedd (2010), zie ook Miller en Halpern (2014). Sommige verschillen tussen jongens en meisjes beginnen al vroeg in de ontwikkeling. Meisjes kunnen bijvoorbeeld al beter lezen wanneer ze naar de basisschool gaan (Robinson en Lubienski, 2011). Daarentegen zijn het jongens die het best zijn in wiskunde ook beter dan de beste 'wiskunde-meisjes' uit de klas in de eerste jaren van de basisschool (Penner en Paret, 2008). Al bij baby's van drie maanden doen jongens het beter dan meisjes bij z.g. 'mentale rotatietaken'. Bij dit type opdracht moet in gedachten een figuur worden gekanteld of geroteerd (Moore en Johnson, 2011 en Quinn en Liben, 2013). Er zijn veel aanwijzingen dat een goede vaardigheid in dit soort mentale operaties belangrijk is voor een goede prestatie op rekenen en wiskunde.

In een bekend overzicht van Doreen Kimura in Scientific American uit 2002 wordt een samenvatting gegeven van subtiele man-vrouw verschillen in cognitieve vaardigheden zoals die in de tientallen jaren daarvoor zijn gevonden en gerapporteerd. $\mathrm{Nu}, 15$ jaar later blijkt er nog steeds dispuut te zijn over de aard van deze verschillen en hun basis. Er ontwikkelt zich op grond van wetenschappelijk onderzoek wel consensus over het feit dat er verschillen zijn tussen (volwassen) mannen en vrouwen. Een eerste vraag-

11 Meer referenties en verdiepende bespreking kunnen worden gevonden in het review van Miller en Halpern (2014) over 'The new science of cognitive sex differences'. 
punt is echter of het hier niet gaat om vrij marginale groepsverschillen. Een tweede discussiepunt is of dergelijke verschillen mogelijk een gevolg zijn van het gegeven dat jongens en meisjes zich - bijvoorbeeld door een andere benadering vanuit ouders en/ of school - sociaal en qua beleving anders ontwikkelen. Daarom blijft het voor topauteurs zoals Halpern (zie Miller en Halpern 2014) de vraag waaróm jongens en meisjes verschillend presteren op verschillende taken en waarom dit soms bij het ene onderzoek wel gevonden wordt en bij het andere niet. Dergelijke verschillen worden vaak geïnterpreteerd als aangeboren verschillen in de hersenen. Echter, ook verschillen tussen jongens en meisjes die al op jonge leeftijd zichtbaar zijn hoeven niet persé door ofwel het een (biologische oorzaken) ofwel het ander (de omgeving) te komen. Op LatijnsAmerikaanse peuterscholen bijvoorbeeld zijn de sekseverschillen in prestaties op wiskundetesten juist omgekeerd: meisjes doen het hier beter. Deze bevinding is in lijn met de opvatting (zie par 3.2.5 en 3.2.6) dat familie en cultuur een belangrijke modulerende rol hebben op de ontwikkeling van vaardigheden; iets wat ook geldt voor de eerste jaren van de ontwikkeling (Penner en Paret, 2008).

\subsubsection{Biologische verschillen in de hersenen en de invloed van hormonen}

Geslachtshormonen hebben een zeer belangrijke rol bij de geslachtelijke ontwikkeling en differentiatie. In de zwangerschap hebben zij een 'organiserend effect' op de hersenontwikkeling. Zij bepalen in deze periode of de foetus zich uiteindelijk tot man of vrouw zal ontwikkelen. Bij de start van de puberteit krijgen de geslachtshormonen een nieuwe rol; zij zorgen dat de organen die voor de geboorte zijn aangelegd zich verder ontwikkelen en functioneel actief worden. Gedurende tienertijd en volwassenheid kunnen geslachtshormonen een meer tijdelijk, 'activerend' effect hebben op het functioneren van de hersenen (Schultz et al., 2009). Met name het mannelijk geslachtshormoon wordt ook wel gebruikt om een prestatieverbetering teweeg te brengen in diverse sporten waar spiermassa en beweging van belang zijn.

Verschillende onderzoeken wijzen erop dat de aanwezigheid van mannelijke geslachtshormonen tijdens de zwangerschap de prestaties bij vrouwen op 'mentale rotatietaken' kan verhogen en die van mannen juist verminderen (Heil et al., 2011 en Vuoksimaa et al., 2010). Op andere cognitieve functies zijn de effecten van hormonen nog onduidelijk, aldus Miller en Halpern (2014). Na de geboorte heeft de aanwezigheid van mannelijke geslachtshormonen een kleiner effect op de cognitie dan als ze tijdens de zwangerschap aanwezig zijn. Deze bevinding is in één lijn met het gegeven dat de gevoeligheid voor mannelijke geslachtshormonen vermindert gedurende de ontwikkeling (Beltz en Berenbaum, 2013 en Schulz et al., 2009).

Ten aanzien van de hersenrijping in de puberteit blijkt uit langlopend onderzoek dat er een subtiele invloed is van geslachtshormonen (Raznahan et al., 2010). Zo waren adolescenten die gevoeliger zijn voor mannelijke geslachtshormonen gekenmerkt door meer mannen-typische patronen in de ontwikkeling in bepaalde gebieden van de hersenschors. Het ging om hersengebieden die relevant kunnen zijn voor jongens- en meisjes- 
verschillen in cognitie, omdat ze onderdeel zijn van veel hersennetwerken en daarmee een rol spelen in veel cognitieve processen.

\subsubsection{Jongens-meisjes verschillen en leerstrategieën}

Gewaarschuwd moet worden voor de aard van de verklaringen die met behulp van hersenonderzoek gegeven worden ten aanzien van cognitieve verschillen tussen jongens en meisjes. Individuele personen kunnen immers een andere strategie gebruiken om een bepaalde cognitieve prestatie neer te zetten. Zo'n strategie is in principe - gedurende vele jaren - aangeleerd door ervaring en oefening en deze legt zich in de microstructuur van de hersenen vast. Als jongens en meisjes verschillende hersengebieden gebruiken voor eenzelfde cognitieve prestatie kan dat dus ook het gevolg zijn van een andere ontwikkeling en het hoeft niet de oorzaak te zijn. (Zie ook Jausovec en Jausovec (2012) en Lenroot en Giedd (2010)). Het is daarom van cruciaal belang om de eerdere ervaringen die in het leven zijn opgedaan mee te nemen in de discussie over jongens-meisjes verschillen. Het is immers de omgeving die sterk bepalend is voor de veranderingen in de microstructuur van de hersenen die zelf weer bepalend zijn voor de verdere cognitieve ontwikkeling. Mogelijk subtiele hersenverschillen tussen jongens en meisjes worden mogelijk in de loop van jaren uitvergroot en geaccentueerd juist doordat jongens en meisjes zich in de samenleving anders ontwikkelen. Lopend onderzoek dat in de afgelopen jaren is gepubliceerd gaat nog niet erg in op dit interpretatieprobleem. Op dit moment ligt in de besprekingen in de literatuur nog de nadruk op al wat oudere theorieën over jongens- en meisjesverschillen tussen de linker- en rechterhersenhelft. Nieuwere theorieën gaan in op bepaalde eigenschappen van de hersenen, zoals de hoeveelheid witte stof en de verbindingen tussen de hersengebieden (Miller en Halpern 2014). Deze nieuwere theorieën hebben het in zich om ook de belangrijke rol van ervaringen en omgeving te incorporeren (zie ook Jolles 2011, 2014).

\subsubsection{Culturele en sociale invloeden}

Cultuur heeft een grote invloed op verschillen tussen jongens en meisjes. In de gemiddelde score op wiskunde bijvoorbeeld, zijn niet in alle landen de jongens in het voordeel; in sommige landen zijn het de meisjes (Stoet en Geary, 2014). Wel blijkt het verschil tussen jongens en meisjes op gebied van lezen en van mentale rotatie vrij robuust te zijn. In veel van de onderzochte landen en culturen blijkt dat meisjes gemiddeld gezien beter zijn in lezen en jongens beter in mentale rotatie. Wel variëren deze verschillen in sterkte tussen de verschillende landen. Zo is er een trend dat het jongens-voordeel in visueel-ruimtelijke informatieverwerking groter is in rijkere landen (Levine et al., 2005). Deze bevinding is mogelijk te verklaren door het feit dat er in deze landen aan kinderen meer mogelijkheden worden geboden om betrokken te zijn bij activiteiten die typisch zijn voor hun sekse. Dat kan omdat er meer speelmogelijkheden en spelmateriaal voorhanden is dat jongens in staat stelt om hun interesse in deze activiteit om te zetten in een grotere ervaring en dus prestatie.

Een andere belangrijke trend is dat jongens- en meisjesverschillen in prestaties op een wiskundetest groter zijn in landen waar de ongelijkheid tussen de seksen groter is. In 
zo'n land kan er ook een groot verschil zijn tussen de hoeveelheid mannelijke versus vrouwelijke onderzoekers, en dat bepaalt weer de keuze van onderzoeksonderwerpen (Else-Quest et al., 2010 en Reilly, 2012). Dit is in ieder geval een voorbeeld van de mogelijke invloed van sociaal-culturele en zelfs politieke factoren; daardoor wordt het beoordelen van de aard en achtergrond van prestatieverschillen tussen individuen erg lastig. Dus zijn prestatieverschillen tussen jongens en meisjes (c.q. mannen en vrouwen) net als verschillen tussen culturen, rassen en leeftijdscohorten alleen goed te beoordelen als erkend wordt dat er veel verschillende factoren bij zijn betrokken. Cultuur, attitude en verwachtingen spelen een belangrijke rol naast de biologie. Daardoor zijn de verantwoordelijke mechanismen moeilijk te duiden. Ten aanzien van sekseverschillen is er een analogie met ongelijkheid op de arbeidsmarkt; volgens sociologen moet onderscheid gemaakt worden tussen verticale ongelijkheid (bv. mannen verdienen onevenredig meer dan vrouwen) en horizontale ongelijkheid (het inkomen tussen mannen en vrouwen is gelijk, maar ze doen verschillende beroepen; Jarman et al., 2012, zie Miller en Halpern voor verdere bespreking). Ook hier kan er sprake zijn van een invloed van de persoonlijke biografie en de eerder in het leven opgedane ervaringen die bepalend zijn voor de uiteindelijke prestaties.

\subsubsection{Gender stereotypes}

Het woord 'gender' wordt gebruikt om een meer psychologische dimensie weer te geven. Gender heeft te maken met psychologische opvattingen over mannelijk versus vrouwelijk gedrag. Het woord sekse daarentegen verwijst naar biologische verschillen tussen man en vrouw. De begrippen gender en sekse zijn dus niet door elkaar vervangbaar. Door de jaren heen is gebleken dat er gewoonlijk anders tegen jongens wordt aangekeken dan tegenover meisjes: 'gender stereotypen'. Deze beïnvloeden cognitieve sekseverschillen door een fenomeen dat wordt beschreven in termen van 'stereotype bedreiging' (Schmader, 2010). Een voorbeeld hiervan is het volgende: wanneer meisjes eraan worden herinnerd dat ze slecht zijn in wiskunde - een negatief stereotype - gaan zij ook inderdaad slechter presteren op een wiskundetest. Deze bevindingen zijn sinds de jaren ' 80 herhaaldelijk gerapporteerd en zijn recentelijk zelfs terug te zien in verschillen in hersenactivatie (Krendl et al., 2008). Dit is van belang voor de aanpak van jongens-meisjes verschillen in het onderwijs. Als de stereotype bedreiging wordt verminderd blijkt dat ervoor te zorgen dat meisjes betere resultaten halen bij natuurkunde (Miyake et al., 2010). Stereotype bedreiging heeft derhalve zowel directe consequenties als consequenties op lange termijn. Miller en Halpern (2014) zijn van mening dat stereotype bedreiging een van de verklaringen kan zijn - alhoewel niet de enige verklaring - van de verschillen tussen mannen en vrouwen op cognitieve testen.

In de afgelopen tientallen jaren is veel onderzoek verricht naar jongens-meisjes verschillen in psychologisch perspectief. Deze literatuur is in die zin belangrijk dat er relatief veel naar verwezen wordt; het gaat om een wat andere dimensie van jongensmeisjes verschillen dan in voorliggend hoofdstuk aan de orde is gekomen. Voor de volledigheid is in appendix 3.1 een overzicht opgenomen van relevante literatuur omtrent 'Genderverschillen in psychologisch perspectief'. 


\subsubsection{Biopsychosociale interacties}

Al jarenlang woedt de discussie of biologie dan wel omgeving belangrijker is als verklaring van cognitieve sekseverschillen. Door de eeuwen heen zijn verschillen tussen mannen en vrouwen verklaard uit 'de aard der dingen: zo is het nu eenmaal....'. Politieke, religieuze en morele overtuigingen bleken echter meer bepalend dan de biologie. De wetenschap wijst echter op de meervoudige bepaaldheid van de geobserveerde sekseverschillen. Om het cru te stellen: van een persoon die geen opleiding krijgt en geen ervaring met bepaalde handelingen kan opdoen, kan niet verwacht worden daarin voldoende competent te worden. Het feit dat er een prestatieverschil gemeten kan worden, zegt echter nog niets over het potentiële talent. Daarom kan het ook niet als bewijs genomen worden voor bestaan van biologisch bepaalde verschillen of potenties. Ook Miller en Halpern (2014) wijzen erop dat er geen tweedeling kan zijn tussen biologie en omgeving. Biologische factoren kunnen bepalen hoe mensen hun omgeving selecteren. De gekozen omgeving zorgt vervolgens weer voor de verdere biologische en psychosociale ontwikkeling (May, 2011). Daarom kunnen de culturele factoren (zoals ongelijkheid in de manier waarop met jongens dan wel meisjes wordt omgegaan) ervoor zorgen dat sekseverschillen zo verschillend kunnen zijn in een verschillende buurt of wijk en in verschillende culturen en landen (Else-Quest et al., 2010). In een biopsychosociale perspectief zijn daarom de biologische- en omgevingsfactoren met elkaar verweven. Ze blijven elkaar voortdurend beïnvloeden in een continu proces (Halpern, 2012, Jolles 2014).

Interdisciplinaire theorieën zoals degene die in de vorige alinea naar voren is gebracht hebben een grotere mogelijkheid om de kennis over de hersenen, cognitie en cultuur te integreren. Dergelijke theorieën hebben meer potentie dan unimodale theorieën omdat ze helpen met het verklaren van opvallende bevindingen. Een voorbeeld daarvan is de waarneming dat er soms uitgesproken jongens- en meisjesverschillen zijn bij de ene taak, maar niet bij een andere taak die daar erg veel op taak lijkt (Harris et al., 2013). In dit soort gevallen zijn het context variabelen die voor de prestatieverschillen kunnen zorgen. Attitude, aansturing door leerkracht en ouder, verwachtingen van de scholier of student: het zijn psychosociale, cognitieve, culturele én non-cognitieve factoren die modulerend zijn op meer biologisch bepaalde geslachtsverschillen in functioneren.

\subsubsection{Genderverschillen in psychologisch perspectief}

In de loop der jaren heeft zich een drietal meer monodisciplinaire theorieën ontwikkeld omtrent jongens- en meisjesverschillen. De eerste is gebaseerd op de evolutionaire psychologie. Deze gaat ervanuit dat jongens- en meisjesverschillen het product zijn van natuurlijke selectie. De verschillen in cognitie, beleving en gedrag hebben zich gedurende honderdduizenden jaren ontwikkeld omdat deze van evolutionair voordeel waren voor de soort, en voor de overleving van de individuen waaruit de soort bestaat. Evolutionaire theorieën gaan vooral in op verschillende taken van mannen en vrouwen, zoals grof genomen de zorg voor veiligheid en voedsel (mannen) en voor de zorg en de primaire leefomgeving (vrouwen; Buss \& Schmitt, 1993). De tweede theoretische stroming is te omschrijven als de cognitieve sociale leertheorie. Deze verklaart de verschillen 
in termen van bekrachtiging ('reinforcement', oftewel belonen en straffen). Gedrag dat bekrachtigd wordt zal in de toekomst vaker voorkomen. Ander gedrag wordt minder frequent en dooft uit (Bussey \& Bandura, 1999). Een derde theorie heeft een meer sociale dimensie: de socioculturele theorie (Eagly \& Wood, 1999). Dit is een alternatief op de evolutionaire theorie. Deze theorie zegt dat de manier waarop de samenleving het werk verdeelt, zorgt voor alle andere psychologische man-vrouwverschillen. In deze theorie is weer wat minder plaats voor de rol van sekseverschillen die met hun biologisch functioneren te maken hebben.

$\mathrm{Er}$ is in de afgelopen veertig jaar veel onderzoek gedaan naar de psychologische aspecten van sekseverschillen. Genderverschillen (zie par 5.4) hebben implicaties voor gedrag, persoonlijkheid, beleving en welzijn. Meer of minder grote verschillen tussen jongens en meisjes zijn door de jaren gevonden in cognitieve functies en presteren, zoals in taal- en verbale vaardigheden en vaardigheden op gebied van rekenen en wiskunde. Grote verschillen zijn ook gerapporteerd in persoonlijkheidsfactoren, in interesses, in emoties en affect en in agressie en impulsiviteit. Psychologische verschillen zijn er ook tussen jongens en meisjes: in hulpbehoevendheid, motivatie, initiatiefname en veel andere psychologische dimensies. Er is een appendix opgenomen bij dit hoofdstuk, waarin een literatuurreview wordt gegeven. Er is voor gekozen om de verdiepende informatie in een appendix te doen en niet in het hoofdstuk zelf. Dit, in verband met de relatief monodisciplinaire invalshoek en het feit dat het onderzoek ingaat op details. Voor voorliggend hoofdstuk is gekozen voor de hoofdlijnen.

De inhoud van de appendix, volgt het belangrijke artikel van Hyde over naar genderverschillen dat in 2014 is gepubliceerd in het toptijdschrift Annual Review of Psychology. Uit het gerapporteerde onderzoek naar genderverschillen is op te maken hoe jongens en meisjes verschillen: niet alleen op gebied van cognitief presteren maar evenzeer op het domein van gedrag, persoonlijkheid, attitude en beleving. Ook dit onderzoek wijst dit erop dat de omgeving belangrijk is en moet worden meegewogen om de verschillen tussen jongens en meisjes te verklaren. Dus naast biologie en cultuur gaat het ook om psychologie, perceptie en sociale cognities en oordelen. Het gaat er voor de samenleving om, die kluwen van elkaar beinvloedende factoren te ontwarren. Daarop wordt ingegaan in de laatste paragraaf van dit hoofstuk.

\subsection{Concluderende opmerkingen}

\subsubsection{Multidimensioneel}

Er woedt al jaren een fel debat over de vraag óf er cognitieve verschillen zijn tussen jongens en meisjes, en áls dat inderdaad zo is, waar die aan te wijten zijn: aan de biologie of aan sociaal-culturele factoren. Beantwoording van deze vraag is van groot belang voor het onderwijs in verband met de snel groter wordende kloof tussen jongens en meisjes (jonge mannen en jonge vrouwen) in studieprestaties en leermotivatie. In dit hoofdstuk werd informatie gepresenteerd uit de biologie, uit de neuro- en cognitieve 
psychologie en uit andere gedragswetenschappen en aanpalende disciplines. Het hoofdstuk stelt dat jongens-meisjes verschillen multidimensioneel - dus door al die invalshoeken - bepaald zijn en zich uiten op gebied van cognitieve vaardigheden, beleving en gedrag. Multidimensioneel wil zeggen dat biologische, psychologische, sociale en culturele factoren ALLE een belangrijke rol spelen. In de tweede plaats is sprake van een 'dynamisch perspectief'. Dit wil zeggen dat de verschillen tussen jongens en meisjes veranderen in de tijd. Er zijn individuele verschillen in hersenrijping, individuele verschillen in het thuissysteem en in de steun, sturing en inspiratie die het kind ontvangt uit de omgeving.

\subsubsection{Adolescentie: een 'age of opportunity'}

Aangezien de hersenrijping zélf mede bepaald wordt door prikkels en stimulatie uit de omgeving is daarmee de cirkel rond: de hersenrijping kan versneld of vertraagd worden door de aard van de prikkels uit de omgeving. Dit betekent dat biologische verschillen tussen jongens en meisjes door de sociale omgeving waarin het kind opgroeit kunnen worden geaccentueerd of juist verminderd. De periode van de adolescentie is in dat opzicht van groot belang. Die periode wordt tegenwoordig gezien als een 'age of opportunity'. Dat is een positief standpunt omdat tot dusver vaak tegen tieners ('pubers') en adolescenten wordt aangekeken in negatieve termen zoals 'nog onbetekenend' en 'lastig'. Ten aanzien van jongens en meisjes suggereren de onderzoeksgegevens dat juist de adolescentie grote mogelijkheid biedt op een verdere ontwikkeling en ontplooiing mits de omgeving de goede voorwaarden daarvoor creëert. De omgeving kan ('moet') de faciliteiten bieden aan tieners om ervaringen op te doen, feedback te krijgen, en daardoor een persoonlijke groei door te maken en uiteindelijk de eigen talenten te kunnen ontplooien.

\subsubsection{Persoonlijke groei voor jongens versus meisjes}

De voorhanden gegevens suggereren dat die persoonlijke groei wel eens wat anders zou kunnen zijn voor de meeste jongens in vergelijking tot de meeste meisjes. Op andere plekken is de visie neergelegd dat het patroon en tijdspad van de ontwikkeling van cognitieve en non-cognitieve functies bij meisjes en jongens wat verschilt (bijvoorbeeld: Jolles 2011). Het zelfinzicht en de empathie bij meisjes lijkt zich wat eerder in de tijd te ontwikkelen. Jongens zijn daarentegen wat sneller in ruimtelijk denken en redeneren. Ook de gemiddeld wat uitgesprokener ondernemingszin van jongens is voor de maatschappij potentieel van waarde, ook al zijn ze gedurende een behoorlijk lange periode in kindertijd en adolescentie nog wat impulsiever dan meisjes. Uit onderzoek zoals in dit hoofdstuk gepresenteerd komt daarom als algemene aanbeveling naar voren om al op de middelbare school (welllicht zelfs al in het basisonderwijs) de voorzieningen en faciliteiten te creëren waarbinnen jongens en meisjes hun neurocognitieve en non-cognitieve functies en talenten beter kunnen ontwikkelen. Meisjes kunnen gestimuleerd worden om meer ondernemend te worden en beter in het ruimtelijk redeneren en creatief denken; jongens om meer zelfinzicht te krijgen en betere sociale cognities te ontwikkelen. Dat vergt wel een andere insteek ten aanzien van 'hoe gaan we met onze adolescenten om?'. Dit hoofdstuk betoogt dat zowel (emotionele) steun, als gerichte sturing en 
inspiratie oftewel het actief routes wijzen van groot belang zijn. Deze visie is strijdig met de stelling die voor het onderwijs in Nederland jarenlang leidend is geweest: de stelling dat de tiener al verantwoordelijk moet zijn voor het eigen leerproces. De nieuwe visie betekent dat ervan uit moet worden gegaan dat er veel tieners zijn (jongens én meisjes) die niet goed kunnen kiezen en beslissen, die slecht zijn in het plannen en nog slechter in het overzien van lange termijn consequenties. Daarvoor heeft de adolescent (jongen én meisje) namelijk de docent, de ouders, de buurvrouw of opa voor nodig. Aan de overheid wordt aanbevolen om nader toegepast onderzoek te doen naar interventies die zijn opgezet volgens dit model. Dergelijke ontplooiende activiteiten dienen door zowel de leraar/docent als door het thuissysteem te worden ontplooid. Het gaat hier dus om een pleidooi voor een pedagogische dimensie en een actievere rol van de leraar/school en thuissysteem. Ook Steinberg komt tot dergelijke aanbeveling in zijn boek uit 2014.

\subsubsection{Individuele verschillen en de rol van de persoonlijke levensgeschiedenis}

Voor de planning en uitvoering van innovaties in het (middelbaar en hoger) onderwijs kan meer effectief worden gewerkt als wordt uitgegaan van het gegeven dat jongens-meisjes verschillen zelf sterk afhankelijk zijn van a) de persoonlijke levensgeschiedenis en eerder opgedane ervaringen, b) omstandigheden in gezin, familie en buurt, c) de aard van de steun, sturing en inspiratie die de scholier/student krijgt van leerkracht en school. Meer aandacht voor de multidimensionale bepaaldheid van de jongens-meisjesverschillen kan zorgen dat effectiever interventies kunnen worden gepland om te zorgen dat zowel jongens als meisjes zich meer 'naar hun talenten' kunnen ontwikkelen. De schrijvers van dit hoofdstuk zijn van mening dat de Educational Neuropsychology hierin een rol van betekenis kan spelen (Jolles 2011).

Aanbeveling aan de overheid en de koepelorganisaties is om meer te differentiëren. Er kan niet worden gesproken van 'de adolescent' of 'de jongen en 'het meisje'. Er zijn ook grote schoolverschillen en verschillen in sociaal-culturele achtergrond van leerlingen. Vanwege de dynamiek van de ontwikkeling van kind en adolescent is het dus vrijwel onmogelijk om op grond van een moment-opname een oordeel te vellen over de potentie van de zich nog ontwikkelende leerling. Immers "een traaggroeiende boom kan uiteindelijk de hoogste boom worden". Meisjes met slechte cijfers op gebied van rekenen-wiskunde blijken zich toch door gerichte aansturing te kunnen ontwikkelen tot een hoge boom. Jongens die ongeconcentreerd en chaotisch zijn blijken 20 jaar later een begenadigd manager of wetenschapper te zijn. Dit leidt tot de aanbeveling om meer en breder onderwijsfaciliteiten te bieden voor jongeren die minder inspiratie of ontplooiingsmogelijkheden hebben gehad - bijvoorbeeld door sociale omstandigheden - . Dit geldt in het bijzonder voor jongens aangezien ze door hun relatief iets langzamer neuropsychologische ontwikkeling kwetsbaarder zijn voor negatieve invloeden uit de omgeving. Ook naar deze suggestie en de mogelijke onderwijsinterventies die hieruit voortvloeien dient vervolgonderzoek te worden uitgevoerd. 


\subsubsection{Let op de groepsgemiddelden}

Veel visies zoals in dit hoofdstuk zijn beschreven zijn gebaseerd op onderzoek dat is gebaseerd op groepsgemiddelden. Dat is iets anders dan individuele resultaten en daarom is nog geen direct oordeel mogelijk over individuele personen (Hyde, 2005). Het is dan ook een open vraag of je met deze groepsgemiddelden de ondervertegenwoordiging van vrouwen in de wetenschap en de bouwkunde kan verklaren (bijvoorbeeld Ceci et al., 2009). Het antwoord is: 'Misschien gedeeltelijk, maar wat is de reden dat vrouwen zich minder in deze vakgebieden begeven? Waar ligt de oorzaak en wat is het gevolg? Als voorbeeld: wanneer je twee personen met elkaar vergelijkt die gelijk scoren op wiskunde, dat is de kans groot dat degene die óók hoog scoort op verbale prestaties, geen natuurwetenschap of bouwkunde gaat studeren, maar een studie kiest waarin de sociale dimensie groter is: 'iets met mensen doen ...' (Wang et al., 2013). Dat kan een hoofdreden zijn dat vrouwen die goed zijn in betavakken tóch geneigd zijn om een alfaof gammastudie te kiezen en ook in hun keuzen zich meer in die richting ontwikkelen dan op het domein bèta. Vice versa geldt dat voor mannen: bij mannen die hoog scoren op bètavakken, techniek en wiskunde, en tegelijkertijd nogal gemiddeld zijn in verbaaltalig presteren is de kans groter dat zij (meer dan vrouwen) voor een bèta-studie kiezen.

\subsubsection{Psychosociale factoren worden steeds belangrijker voor te maken keuzen}

Ook andere factoren spelen een rol in het verklaren van de verschillende carrièrekeuzes van mannen en vrouwen. De balans tussen werk en familie is daarin een belangrijk voorbeeld; vrouwen investeren meer in de verzorging van de kinderen dan mannen (Ceci et al., 2009) en daardoor wordt een steeds groter deel van hun mentale energie en ook ervaring ontwikkeld op dit domein (en dus niet op gebied van bèta-beroepen). Een gevolg van de andere oriëntatie van vrouwen en mannen en hun steeds groter wordende verschil in interesses en tijdsbesteding (en toekomst-oriëntatie) is dat vrouwen, meer dan mannen, liever een baan hebben die bijdraagt aan de gemeenschap 'ik wil met mensen werken, mensen helpen, zorgen ...'(Diekman et al, 2011).

Ten aanzien van maatschappelijke interventies op dit domein zijn er geen duidelijke aanwijzingen dat scholen met alleen mannen of vrouwen of juist gemengde scholen voordeliger zijn (Mael et al., 2005 en Pahlke et al., 2013). Ook hier gaat het vooralsnog om een complex probleem waarbij ook culturele en politieke factoren een belangrijke rol spelen. Discussie over het belang van jongens- en meisjesscholen in Engeland wordt vooralsnog sterk bemoeilijkt door het feit dat de rol van de klassenmaatschappij in Engeland hierin ook een rol speelt. Bespreking van dit onderwerp valt buiten de scope van dit hoofdstuk.

\subsubsection{Wegnemen van stereotype bedreigingen}

Een punt dat voor de onderwijsinnovaties in Nederland wél voor de korte termijn relevant zou kunnen zijn om schoolprestaties te verbeteren, is het wegnemen van stereotype bedreigingen. Daar is veel winst te behalen, dit geldt zowel voor mannen als voor vrouwen (Miyake et al., 2010 en Hartly en Sutton, 2013). Elders is voorgesteld om meisjes meer te stimuleren om ervaring op te doen met nieuwsgierig en ondernemend te zijn, 
en interessen te ontwikkelen op gebied van klassieke 'jongens onderwerpen'. Aan de andere kant kunnen jongens al vanaf de lagere schooltijd gestimuleerd worden om communicatieve taal alsmede empathie en zelfinzicht te ontwikkelen (Jolles 2011, Jolles 2014, 2015).

\subsubsection{De belangrijke rol van de peer group}

Er is door de jaren veel geschreven over de rol van de peer group. Deze is over de hele periode van de adolescentie tot in de jonge volwassenheid enorm groot. Bespreking van deze invloeden valt buiten de scope van dit overzichts- en opiniehoofdstuk. Wel is het relevant om bij de keuze van methoden om de talentontwikkeling van jongens en meisjes aan te pakken ook intensief aandacht te besteden aan de peergroup. $\mathrm{Er}$ is immers bekend dat veel adolescenten een groter belang hechten aan het oordeel van hun leeftijdsgenoten dan aan het eigen oordeel. Omdat kiezen en beslissen belangrijke non-cognitieve functies zijn ligt het voor de hand dat interventies die gericht zijn op verbeteren van non-cognitieve functies, van leermotivatie, studiegedrag en plannen, prioriteren, verhogen van het zelfinzicht en dergelijken, zich ook dienen te richten op de attitude van de adolescent, en daarmee hem of haar leren op de oordelen van de peergroup meer op hun echte waarde te wegen. Meer onderzoek naar deze sociale beïnvloeding dient plaats te vinden; ook is een verdiepend literatuur review terzake aan de orde.

\section{BELEIDSAANBEVELINGEN}

- Ten aanzien van de factoren die verantwoordelijk kunnen zijn voor jongens-meisjes verschillen is in dit hoofdstuk een verklarend model gepresenteerd. Dit wordt in de eerste plaats gekenmerkt door het begrip 'multidimensioneel' (dat wil zeggen dat biologische, psychologische, sociale én culturele factoren alle belangrijk zijn). In de tweede plaats gaat het om 'ontwikkeling en dynamiek': de ontplooiing van kinderen en adolescenten is pas ver na het $20^{\circ}$ jaar voltooid en daarin bestaan grote verschillen. Dat heeft grote implicaties voor onderwijs- en pedagogische interventies. Aanbevolen wordt om gerichte onderwijsinterventies uit te zetten waarin rekening gehouden wordt met de individuele verschillen en die te hanteren als een handvat om leerlingen/studenten gericht te sturen en inspireren.

- (De meeste) jongens en (de meeste) meisjes ontwikkelen zich volgens een iets ander tijdpad en dynamiek. Aanbevolen wordt om de heilloze nietes-welles discussie over het al dan niet bestaan van jongens-meisjes verschillen achter ons te laten. De verschillen bestáán. Maar de maatschappelijke betekenis ervan kan juist positief zijn. Er kan veel gerichter dan nu wordt gedaan worden ingezet op de persoonlijke groei en talentontwikkeling van jongens én van meisjes. Inzetten op het stimuleren van (opdoen van) ervaringen en de persoonlijke groei kan de ontwikkeling van non-cognitieve functies versterken. En dat heeft vervolgens naar verwachting een positieve uitwerking op leermotivatie en studieprestaties. 
- Psychosociale en culturele factoren lijken behoorlijk belangrijk te zijn ten aanzien van het zich uiten van de jongens-meisjes verschillen. Aanbevolen wordt om meer in te zetten op docent professionalisering ten aanzien van de kennis over jongens-meisjes verschillen. En om in het onderwijs meer rekening te houden met het feit dat de gemiddelde laat-adolescent zich nog niet volledig heeft ontplooid op het moment dat hij of zij wél juridisch meerderjarig wordt. Dat wil zeggen dat in mbo en ho aandacht moet komen voor het geven van faciliteiten voor de persoonlijke groei.

- Er zijn vele andere mogelijkheden die in de literatuur aangedragen zijn en nog aangedragen kunnen worden op grond van onderzoek zoals in dit hoofdstuk beschreven. Aan het ministerie wordt in overweging gegeven om een vervolgopdracht te geven voor het in kaart brengen van de verschillende mogelijkheden voor onderwijsinterventies en pedagogische interventies langs lijnen zoals hier besproken: 'in een neuropsychologisch perspectief'. Er is nog heel weinig onderzoek op dit gebied gepubliceerd maar er is wel veel'circumstantial evidence' dat wijst in de richting van 'in potentie goed bruikbaar in de praktijk'. Het beleid ten aanzien van een onderwijsvernieuwing ten voordele van de talentontwikkeling van jongens én van meisjes kan worden ondersteund door meer concrete aanpak in dezen te formuleren. 


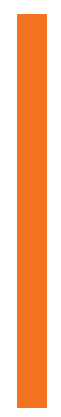




\section{Appendix 03}

APPENDIX 3.1

GENDERVERSCHILLEN IN PSYCHOLOGISCH PERSPECTIEF

Verantwoording

In de afgelopen tientallen jaren is veel onderzoek verricht naar jongens-meisjes verschillen in psychologisch perspectief. Deze literatuur is in die zin belangrijk dat er relatief veel naar verwezen wordt, ook al zijn de laatste jaren veel aanwijzingen verkregen dat er naast psychologische ook sociale en biologische factoren een belangrijke rol spelen. Deze appendix hoort bij hoofdstuk 3. Ten aanzien van de gedragswetenschappelijke invalshoek wordt gewoonlijk de term 'gender' gebruikt en niet de term 'sekse'. Bedoeling van deze appendix is om de lezer inzicht te geven in de aard van bestaande (psychologische) theorieën en bevindingen die relevant kunnen zijn om prestatieverschillen tussen jongens en meisjes in het onderwijs beter te kunnen begrijpen. Het is als zodanig een meer monodisciplinaire uitwerking van onderzoek dat nader beschreven is in hoofdstuk 3 , alwaar de gegevens in een multidisciplinair en multidimensioneel perspectief worden gepresenteerd. De appendix houdt de indeling aan die gebruikt is in het overzicht van Hyde (2014) in de Annual Review of Psychology.

\subsubsection{Inleidend}

In de loop der jaren heeft zich een drietal meer monodisciplinaire theorieën ontwikkeld omtrent jongens- en meisjesverschillen. De eerste is gebaseerd op de evolutionaire psychologie. Deze gaat ervanuit dat jongens- en meisjesverschillen het product zijn van natuurlijke selectie. De verschillen in cognitie, beleving en gedrag hebben zich gedurende honderdduizenden jaren ontwikkeld omdat deze van evolutionair voordeel waren voor de soort, en voor de overleving van de individuen waaruit de soort bestaat. Evolutionaire theorieën gaan vooral in op verschillende taken van mannen en vrouwen, zoals grof genomen de zorg voor veiligheid en voedsel (mannen) en voor de zorg en de primaire leefomgeving (vrouwen; Buss en Schmitt, 1993). De tweede theoretische stroming is te omschrijven als de cognitieve sociale leertheorie. Deze verklaart de verschillen in termen van bekrachtiging ('reinforcement', oftewel belonen en straffen). Gedrag dat bekrachtigd wordt zal in de toekomst vaker voorkomen. Ander gedrag wordt minder frequent en dooft uit (Bussey en Bandura, 1999). Een derde theorie heeft een meer sociale dimensie: de socioculturele theorie (Eagly en Wood, 1999). Dit is een alternatief op de evolutionaire theorie. Deze theorie zegt dat de manier waarop de samenleving het werk verdeelt, zorgt voor alle andere psychologische man-vrouwverschillen. In deze 
theorie is weer wat minder plaats voor de rol van sekseverschillen die met hun biologisch functioneren te maken hebben.

In deze paragraaf wordt ingegaan op de psychologische kant van sekseverschillen. Wat besproken wordt heeft een andere nadruk dan de inzichten die in voorgaande paragrafen aan de orde gekomen zijn. Het gaat om genderverschillen (geïntroduceerd in par. 3.5.4) en ook om implicaties voor gedrag, persoonlijkheid, beleving, belevingsproblematiek en welzijn. De paragraaf volgt het belangrijke artikel van Hyde over verschillen tussen jongens en meisjes dat in 2014 is gepubliceerd in het toptijdschrift Annual Review of Psychology. Het doel van de paragraaf is om duidelijk te maken hoe jongens en meisjes verschillen, niet alleen op gebied van cognitief presteren, maar evenzeer op het domein van gedrag, attitude en beleving. Weer wijst dit erop dat ook de omgeving belangrijk is om de verschillen te verklaren. Dus naast biologie en cultuur gaat het ook om psychologie, perceptie en sociale oordelen.

\subsubsection{Wiskundige vaardigheden en ruimtelijk inzicht}

In 1990 scoorden mannen hoger dan vrouwen op enkele wiskundige testen, maar tegenwoordig liggen de prestaties van mannen en vrouwen min of meer gelijk (Hyde et al. 1990 en Hyde et al. 2008a). Zoals besproken in par. 3.5.2. zijn er tussen landen verschillen tussen jongens en meisjes in wiskundeprestaties; in sommige landen presteren de jongens beter en in andere de meisjes (Else-Quest et al, 2010). Een andere opvallende bevinding in dergelijk onderzoek is dat man-vrouwverschillen in attitude tegenover een wiskundetest groter zijn dan de verschillen in de test zelf: mannen rapporteren zelfverzekerder te zijn en vrouwen rapporteren angstiger te zijn bij het maken van de test (zie Hyde voor bespreking).

Ook ten aanzien van mentale rotatietaken - waarin jongens gewoonlijk beter presteren(zie par. 3.5.2.) zijn psychologische factoren van belang. Zo werd in een meta-analyse een groot verschil gevonden in het voordeel van mannen bij een mentale rotatietaak waarbij de proefpersonen een 3D object in hun hoofd moesten draaien (Linn en Petersen (1985). Tien jaar later werd er weer een meta-analyse uitgevoerd maar toen was het verschil tussen mannen en vrouwen gedaald in sterkte (Voyer et al. 1995). Later is gebleken dat in dit onderzoek te weinig rekening is gehouden werd met het effect van tijdsdruk. Vrouwen hebben hier meer moeite mee dan mannen. Het verschil tussen mannen en vrouwen is vooral groot op een mentale rotatietaak mét tijdsdruk. Zonder tijdsdruk is er echter minder verschil (Voyer, 2011).

Als verklaring voor het mannelijk voordeel in ruimtelijk inzicht wordt wel eens genoemd dat mannen meer tijd besteden aan, en ervaring hebben in het spelen van computerspelletjes. Daarvoor zijn de mentale rotatievaardigheden nodig en de grotere ervaring van mannen zou het sekseverschil kunnen verklaren (Rideout et al. 2010). Ook dit is waarschijnlijk niet de beste verklaring aangezien mannen (en jongens) meer dan meisjes interesse hebben in dit type spel. Het is dus goed mogelijk dat mannen/jongens een basale - waarschijnlijk biologisch bepaalde - voorsprong hebben in het vermogen om 
goed te worden in het mentaal roteren. En deze lichte ontwikkelingsvoorsprong vertaalt zich uiteindelijk in een groot verschil in vaardigheid omdát mannen/jongens de vaardigheid gaan oefenen. Meer experimenteel onderzoek is nodig om deze mogelijkheden nader te onderzoeken.

\subsubsection{Verbale vaardigheden}

Er is nogal veel onderzoek waaruit blijkt dat vrouwen iets beter zijn in taal en verbale vaardigheden. De onderzoeksliteratuur is daarover consistent en bestrijkt tientallen jaren (voor een relatief vroege studie: Hyde en Linn, 1988). Vrouwen lijken bijvoorbeeld in het voordeel te zijn als het gaat om verbale vlotheid. Ook is er veel onderzoek dat erop wijst dat meisjes beter zijn in lezen, en ook meer gemotiveerd zijn om te lezen (Reilly, 2012). Opvallend was echter wel dat de groep van jongens die het laagst scoorden op leesvaardigheid 4.5 keer zo groot was als de groep meisjes die het laagst scoorden. De vraag is dan ook in hoeverre jongens met leerproblemen het gemiddelde van de jongensprestaties naar beneden halen. Ook wanneer internationaal gekeken wordt, zijn vrouwen in het voordeel. Opvallend hierbij is dat de grootte van deze verschillen samenhangen met de ongelijkheid in een land, zoals voorspeld door de socioculturele theorie (Hyde 2014). Ten aanzien van de talige communicatie zijn er ook verschillen. Vrouwen lijken in hun taalgebruik wat voorzichtiger, aldus Leaper en Robnett (2011). Zo lijken ze meer dan mannen instemming te vragen ('dat was een mooie film, niet waar?') en meer omslachtig te praten ('lk vind dat boek eigenlijk best wel mooi').

\subsubsection{Verschillen in persoonlijkheid en gedrag}

Uit vragenlijstonderzoek bleek dat meisjes hoger scoren op impulscontrole en aandacht (Else-Quest et al. 2006). Mannen scoorden daarentegen hoger op activiteit en impulsiviteit dan vrouwen. Ook op het zogenaamde Big Five model voor de persoonlijkheid (Feingold 1994) bleken jongens- en meisjesverschillen (McCrae en Costa 2013). De vrouwen scoorden hoger op angst, een onderdeel van de neuroticismeschaal. Verder scoorden jongens hoger op assertiviteit. Er was ook een groot verschil in scores op vriendelijkheid (tender-mindedness) in het voordeel van de vrouwen. Deze verschillen gelden voor de VS, alwaar dit onderzoek is uitgevoerd. In andere culturen blijken de jongensmeisjes verschillen anders. Zo werd het verschil in scores op neuroticisme dat wel in de VS werd vastgesteld, niet teruggevonden onder Japanners en Zuid Afrikanen (Costa et al., 2001). Dergelijk onderzoek laat zien dat de persoonlijkheidsverschillen vooral zichtbaar zijn in welvarende culturen. Het feit dat vrouwen in dergelijke culturen de mogelijkheid hebben tot scholing wordt als een belangrijke verklarende factor gezien (bv Hyde 2014).

Ten aanzien van impulsiviteit blijken vrouwen iets gevoeliger te zijn voor negatieve feedback ('straf'), terwijl er geen verschil is gevonden in de gevoeligheid voor beloningen tussen mannen en vrouwen (Cross et al. 2011). Mannen hebben meer neiging tot sensation seeking dan vrouwen. Dit is terug te zien op zowel vragenlijsten als met gedragsobservaties. 
Emoties. Vrouwen scoren hoger dan mannen op positieve emoties en dat sekseverschil wordt groter met leeftijd (Chaplin en Aldao 2013). Dit hangt mogelijk samen met de druk om te socialiseren. Die neemt met de leeftijd toe en vrouwen hebben hier minder moeite mee. Ten aanzien van emoties wordt de sterkte van de jongens-meisjesverschillen bepaald door de context. De aanwezigheid van ouders kan er bijvoorbeeld voor zorgen dat meisjes hun emoties meer internaliseren dan jongens (zij uiten de emoties dus op een voor de buitenwereld minder merkbare manier). Else-Quest en collega's (2012) vonden in hun onderzoek dat vrouwen iets meer schuld en schaamte ervaren dan mannen.

Interesses. Zoals besproken door Hyde (2014) zijn er sterke aanwijzingen dat vrouwen vooral geïnteresseerd zijn in mensen en mannen vooral in dingen (bijvoorbeeld Su et al., 2009). Dit verschil was erg sterk en zou kunnen verklaren waarom er in verhouding weinig vrouwen terug te zien zijn in de wetenschap, technologie, bouwkunde en wiskunde.

Agressie. Jongens lijken gemiddeld wat agressiever dan meisjes (Archer, 2004). Het is echter belangrijk om ook te kijken naar de context: de gender rol, de verwachtingen in houding en gedrag die mensen hebben van jongens en meisjes, blijkt hierin een belangrijke rol te spelen. Een toelichting bij dit punt komt uit het onderzoek van Lightdale en Prentice uit de jaren '9o (1994). Zij deden een onderzoek waarbij onderscheid werd gemaakt tussen een persoonlijke setting en een anonieme setting. In de persoonlijke setting zaten de deelnemers dicht bij de onderzoekers, er werd een aantal persoonlijke vragen gesteld en kregen ze een naambordje op. In de anonieme setting zaten ze ver van de onderzoeker af en moesten ze in stilte wachten tot ze hun taak mochten doen. De taak bestond uit een computerspel waarbij de proefpersonen bommen moesten laten vallen - een indicatiemaat voor agressie. Wanneer er vergelijkingen werden gemaakt in de persoonlijke setting, scoorden mannen significant hoger op agressie. Echter, wanneer de scores binnen de anonieme setting werden vergeleken, was er geen verschil tussen jongens en meisjes. Er was geen onderzoeker die over hun rug meekeek, dus de druk om zich conform de genderrol te gedragen was er in deze conditie niet. Vandaar dat gedacht wordt dat dit een verschil tussen jongens en meisjes weerspiegelt dat meer met hun sekse dan met hun gender samenhangt.

Hulpgedrag. Of mannen en vrouwen iemand zouden helpen, blijkt erg situatie- en context afhankelijk te zijn (Eagly en Crowley, 1986 en Eagly, 2009). Mannen zouden sneller iemand helpen wanneer er sprake kan zijn van gevaar of als het om een technisch probleem gaat (voorbeeld: het vervangen van een lekke band). Wel is de kans een stuk groter dat mannen iemand helpen wanneer er andere mensen toekijken; de held uithangen heeft niet zoveel zin als er niemand kijkt. Vrouwen zouden eerder een verzorgende rol op zich nemen, zoals bijvoorbeeld het helpen van een huilend kind. 
Seksualiteit. De meta-analyse van Petersen en Hyde (2010) onderzocht attitudes van mannen en vrouwen tegenover seksualiteit. Er werden veel overeenkomsten gevonden. Een paar dingen waarin mannen verschilden in vergelijking met vrouwen is dat ze volgens hun zelfrapportage meer masturbeerden, meer porno gebruikten, meer seksuele partners hadden en positiever aankeken tegen ongedwongen seks. Wel werd er gevonden dat verschillen in attitudes kleiner werden in de loop der jaren. Net als bij het onderzoek naar agressie, is het de vraag in hoeverre de vragenlijst is ingevuld conform de genderrollen.

Verschillen in welzijn: Depressie. Onderzoeken laten vaak zien dat vrouwen gemiddeld depressiever zijn dan mannen. (bv. Kessler et al., 1993). Wel bestaan hierin bepaalde trends. In het onderzoek van Twenge en Nolen-Hoeksema (2002) waren er bij kinderen tussen de 8 en 12 jaar nog geen verschillen tussen jongens en meisjes in hun depressiescore. Bij kinderen tussen de 13 en 16 scoorden de meisjes wel wat hoger op een depressieschaal. Wanneer je de scores op een depressieschaal van jongens en meisjes over de tijd bekijkt, zie je dat de score van jongens relatief constant blijft, terwijl meisjes steeds hoger (depressiever) scoren.

Om verschillen in depressie tussen jongens en meisjes te verklaren hebben Hyde en collega's (2008b) "het ABC model van sekseverschillen in depressie" ontworpen. Het model voegt affectieve, biologische en cognitieve factoren samen waarmee wordt geprobeerd de gevoeligheid van meisjes voor depressie te verklaren. Negatieve gebeurtenissen in combinatie met een gevoeligheid voor depressie, zorgen vooral bij meisjes voor depressie. De biologische factoren liggen vooral in de geslachtshormonen en de start van de puberteit. Affectieve factoren zijn factoren die met persoonlijkheid te maken hebben, zoals negatieve affectiviteit. Cognitieve factoren zijn bijvoorbeeld cognitieve kwetsbaarheid en piekeren. Deze factoren zorgen samen voor een hogere gevoeligheid voor depressie bij meisjes in de adolescentie.

Zelfvertrouwen. Hoewel over het algemeen wordt gezegd dat vrouwen minder zelfvertrouwen hebben dan mannen, ligt dit beeld genuanceerd. Op de lagere school is het verschil in zelfvertrouwen klein, gedurende het eind van de basisschool en op de middelbare school neemt dit verschil toe (Kling et al. 1999). Wanneer de jongens en meisjes naar college gaan en daarna volwassen worden, wordt het verschil weer kleiner. Deze jongens- en meisjesverschillen in zelfvertrouwen zijn niet terug te vinden onder etnische minderheden, wat zou betekenen dat de hoeveelheid zelfvertrouwen die jongens en meisjes ervaren cultureel afhankelijk is (Hyde 2014). 


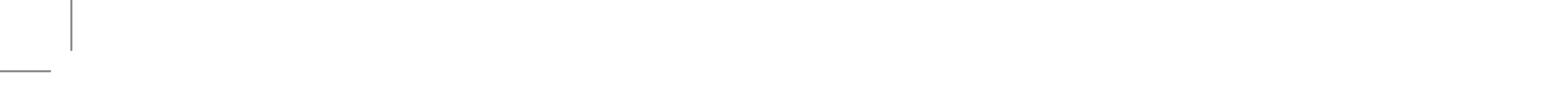




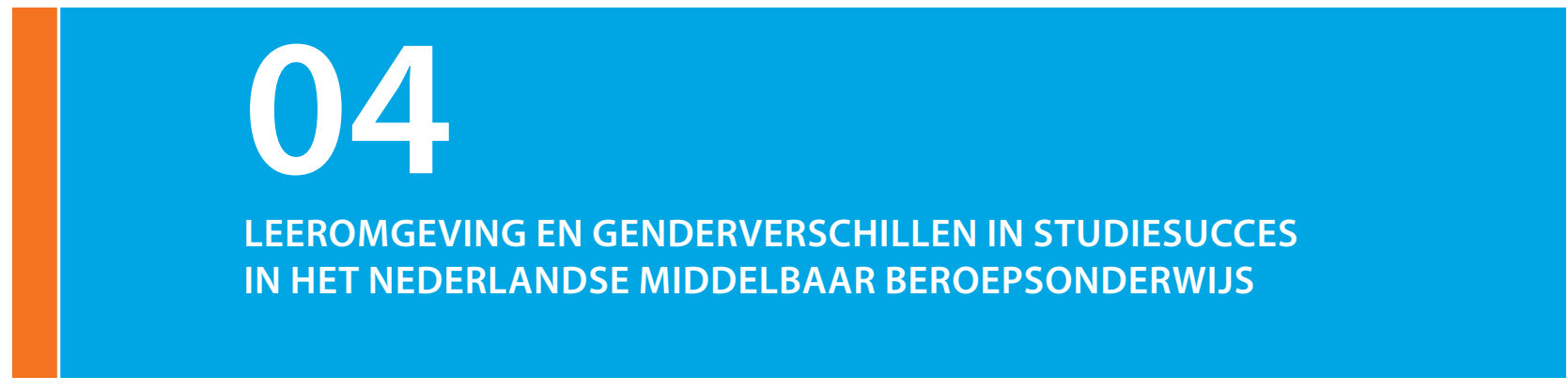

\section{Mark Levels en Rolf van der Velden \\ (Researchcentrum voor Onderwijs en Arbeidsmarkt)}

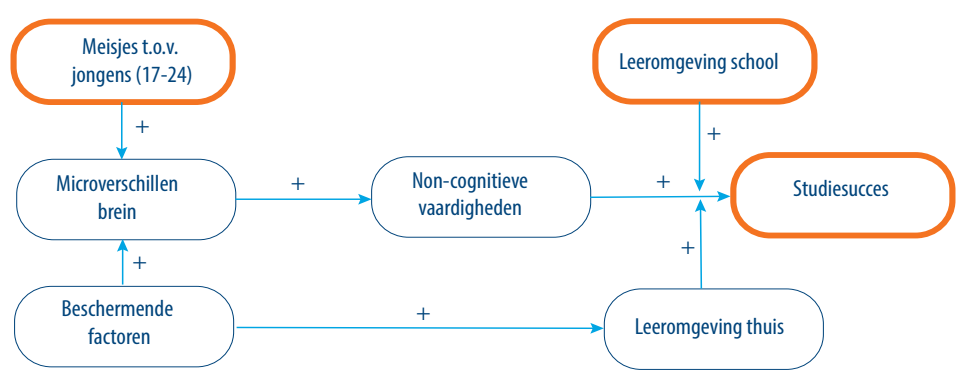

\section{Samenvatting}

Er is maar weinig bewijs voor de aannames, uiteengezet in hoofdstukken 2 en 3, dat meisjes meer baat zouden hebben bij leeromgevingen waarin communicatie, zelfstandigheid en nauwkeurigheid worden vereist. In dit hoofdstuk gaan we na of en in hoeverre prestatieverschillen tussen jongens en meisjes in het mbo zijn toe te schrijven aan de momenteel in het mbo vigerende competentiegerichte leeromgevingen. We maken gebruik van de gefaseerde invoer van kwalificatieprofielen in het mbo, die opgevat kan worden als natuurlijk experiment. We vergelijken de diplomakansen van studenten die hun opleiding volledig als eindtermenopleiding hebben genoten met de kansen van vergelijkbare studenten die op een ander moment in dezelfde instelling zijn ingestroomd in diezelfde beroepsopleiding en daardoor al met competentiegericht onderwijs in aanraking zijn gekomen, en ook met de diplomakansen van vergelijkbare mensen die in dezelfde instelling aan dezelfde beroepsopleiding zijn opgeleid, maar die door hun instroommoment in een opleiding zijn opgeleid die volledig volgens competentiegerichte kwalificatiedossiers was opgeleid. De resultaten laten overtuigend zien dat meisjes en jongens in eindtermenopleidingen een ongeveer even grote kans hebben om een diploma te halen in de studie waarin ze zijn ingestroomd. In opleidingen waarin tijdens de opleidingsduur al kwalificatiedossiers werden ingevoerd, doen meisjes het iets beter dan jongens. Maar meisjes doen het aanzienlijk veel beter 
dan jongens in opleidingen die vanaf het moment van instroom zijn ingericht volgens de kwalificatiegerichte dossiers. De analyses vormen een sterke ondersteuning van de aanname dat competentiegerichte leeromgevingen bijdragen aan de verklaring van prestatieverschillen tussen jongens en meisjes in het Nederlandse mbo.

\subsection{Inleiding}

Een belangrijke algemene verklaring van het toegenomen schoolsucces van meisjes ligt in de aanname dat meisjes beter in staat zijn te presteren in competentiegerichte leeromgevingen (Philbin, Meier et al. 1995). Er zijn wetenschappelijke theorieën die voorspellen dat meisjes eerder in staat zouden zijn zelfstandiger, nauwkeuriger en meer gedisciplineerd te werken (Bean and Vesper 1992, Jorgensen, Ferraro et al. 2009); precies die eigenschappen die worden aangesproken in competentiegerichte leeromgevingen. In dit hoofdstuk gaan we na hoe deze theoretische aanname uitpakt in de onderwijspraktijk in het Nederlandse middelbaar beroepsonderwijs.

We maken daarbij gebruik van de gefaseerde invoer van de beroepsgerichte kwalificatiedossiers in het mbo, die het afgelopen decennium het onderwijs ingrijpend heeft geherstructureerd (Van der Meijden et al., 2014). In beroepsgerichte kwalificatiedossiers is voor alle opleidingen vastgelegd welke kerntaken afstudeerders in hun beroepsuitoefening moeten kunnen vervullen en in welke concrete werkprocessen die taakuitvoering in de beroepspraktijk tot uitdrukking komt. Ook is er voor elk van de werkprocessen vastgelegd welke specifieke competenties scholieren moeten ontwikkelen.

Sinds 2012 zijn alle opleidingen waarin scholieren in het middelbaar beroepsonderwijs kunnen instromen, ingericht volgens een beroepsgericht kwalificatieprofiel. Vóór 2012 werkten veel opleidingen nog met zogeheten eindtermendossiers, waarin stond vastgelegd over welke kennis en vaardigheden afgestudeerden dienden te beschikken. $\mathrm{Al}$ sinds 2004 is er door een telkens toenemend aantal opleidingen geëxperimenteerd met competentiegerichte kwalificatiedossiers. Die gefaseerde invoer vormt een natuurlijk experiment, waarvan de (complexe) gevolgen voor schoolprestaties in beginsel meetbaar zijn (Van der Meijden et al., 2013).

De herstructurering van de kwalificatiedossiers biedt ook een aardige gelegenheid om na te gaan of en in hoeverre prestatieverschillen tussen jongens en meisjes in het mbo samenhangen met de invoer van competentiegerichte leeromgevingen. Daarbij moeten we aannemen dat de invoer van de competentiegerichte kwalificatiedossiers overeenkomt met de invoer van competentiegericht onderwijs (cgo) (Van der Meijden e.a., 2009). Het cgo is evenwel niet altijd op dezelfde wijze in ROC's geïntroduceerd en geïmplementeerd en het invoeren van het cgo heeft niet tot een verschuiving naar één enkele didactiek geleid (Van der Meijden en Petit, 2014). Desondanks is het mogelijk om, onder redelijke aannames, iets te kunnen zeggen over de gevolgen van de invoer van kwalificatiedossiers voor de prestatiekloof tussen jongens en meisjes in het mbo. De invoer van de met kwalificatiedossiers samenhangende herstructurering van het middelbaar be- 
roepsonderwijs heeft immers in brede zin geleid tot veranderingen in de onderwijsvormgeving, waarbij de voorheen meest gebruikte, op het algemeen vormend onderwijs geïnspireerde onderwijsvormen die waren opgebouwd rondom vakken en vakdidactiek in toenemende mate hebben plaatsgemaakt voor vormen waarin het straks uit te oefenen beroep leidend is voor de ontwikkeling van beroepsgebonden en persoonlijke competenties (Van der Meijden en Petit, 2014). ${ }^{12}$ Een en ander ging vaak gepaard met een invoer van competentiegerichte leeromgevingen, die volgens de theorie gunstiger zouden zijn voor de prestaties van meisjes dan voor de prestaties jongens.

Om na te gaan of en in hoeverre leeromgevingen bijdragen aan de verklaring van prestatieverschillen tussen jongens en meisjes in het mbo, hebben we geanalyseerd of en in hoeverre de invoer van competentiegerichte kwalificatiedossiers verschillende effecten heeft gehad voor jongens en voor meisjes. Als de theoretische aannames over de rol van contexten zoals uiteengezet in Hoofdstuk 2 en 3 hier verklaringskracht hebben, dan zouden we verwachten dat meisjes meer baat zouden hebben gehad bij de invoer van het competentiegericht onderwijs dan jongens. We toetsen deze hypothese in dit hoofdstuk. Studiesucces is een breed begrip, dat indicatoren als doorstroomtijd, uitval, eindcijfers en arbeidsmarktsucces kan omvatten. In dit hoofdstuk beperken we ons tot de mate waarin jongens en meisjes verschillende kansen hebben om een diploma te halen in de opleiding waarin zij instroomden. Meer specifiek toetsen we de volgende hypothese:

TEKSTBOX 4.1 Hypothese

Het verband tussen het volgen van competentiegericht onderwijs en de kans een diploma te halen in de opleiding waarin men is gestart, is sterker positief voor meisjes dan voor jongens.

\subsection{Data}

We maken voor de analyse gebruik van een tweetal gegevensbronnen. Een eerste belangrijke bron van informatie betreft informatie over de opleidingen. Mbo-opleidingen staan in Nederland met een uniek identificatienummer geregistreerd in het Centraal Register Beroepsopleidingen (crebo). Het bronbestand bevat aan de registers ontleende gegevens over 19.075 mbo-opleidingen die tussen 2006 en 2011 onder 122 verschillende brin-nummers ${ }^{13}$ voorkwamen. Aan de hand van het registratienummer waarmee opleidingen in het Centraal Register zijn geregistreerd, is vast te stellen of en in hoeverre op een opleiding gewerkt wordt met eindtermen of competentiegerichte kwalificatiedossiers. In tabel 4.1 wordt daarvan een kort overzicht gegeven.

\footnotetext{
12 In de conclusieparagraaf komen we terug op deze aannames.

13 Brin-nummers kunnen verwijzen naar instellingen, maar soms ook naar verschillende, onder een instelling ressorterende, vestigingen
} 
TABEL 4.1 Instroom in opleidingen met verschillende inrichtingsvormen

\begin{tabular}{|l|l|r|r|r|r|r|r|r|}
\hline Crebo & Betekenis & Instroom & Instroom & Instroom & Instroom & Instroom & Instroom \\
\hline $10000-19999$ & Kwalificatie op basis van eindtermen & 43441 & 2006 & 2007 & 15354 & 5747 & 385 & 41 \\
\hline & & & & & & & \\
\hline $90000-99999$ & Kwalificatie op basis van competenties & 44799 & 61273 & 78792 & 87335 & 91214 & 89608 \\
\hline
\end{tabular}

Uit het crebo-nummer kan worden afgeleid of een scholier onderwijs heeft genoten in een opleiding met een eindtermendossier (crebo's die beginnen met een 1), of een competentiegericht kwalificatiedossier (crebo's die beginnen met een 9). ${ }^{14}$ Scholieren kunnen dus in twee verschillende typen opleidingen instromen: (1) een opleiding met een op eindtermen gericht curriculum, óf (2) een opleiding met een op competentiegerichte kwalificatiedossiers gericht curriculum. Het is mogelijk dat instellingen nog tijdens lopende opleidingen zijn overgegaan tot het invoeren van competentiegericht onderwijs. In dat geval kan een opleiding die binnen één instelling voor één beroep opleidt, twee verschillende crebo-codes hebben, en wel omdat de crebo-code verandert wanneer een curriculum verandert. Om opleidingen te identificeren binnen welke dat inderdaad zo is, hebben we op basis van een koppeltabel ${ }^{15}$, voor opleidingen die binnen instellingen opleiden voor hetzelfde beroep, de oude crebo's aan de nieuwe crebo's gekoppeld. In deze koppeltabel zijn crebo-codes op basis van vakinhoudelijke verwantschap gekoppeld aan een beroep. Wij hebben deze tabel gebruikt om vast te kunnen stellen voor welke opleidingen die binnen een instelling opleiden tot een beroep er meerdere crebo-codes voorkwamen. Opleidingen die binnen instellingen startten als eindtermenopleiding maar waarvoor binnen het niveau van beroepen op enig moment een nieuwe, op de invoer van cgo duidende crebo is ingevoerd, zijn door ons aangemerkt als opleidingen waarbinnen men theoretisch van onderwijsvorm gewisseld zou kunnen zijn tijdens lopende opleidingen. In veel gevallen verliep de overgang van oude naar nieuwe opleidingen vloeiend, maar er waren ook opleidingen binnen welke meerdere crebo-codes opleidden tot hetzelfde beroep. In deze gevallen zijn wij er van uitgegaan dat voor alle opleidingen die binnen één instelling opleiden voor hetzelfde beroep, het cgo is ingevoerd op het moment dat dat voor één van die opleidingen zo was. In box 4.2 staat een drietal voorbeelden uitgewerkt.

\footnotetext{
14 Proeftuin-scholen voor kwalificaties op basis van competenties (crebo's die beginnen met 7, m.u.v. 79 ) kwamen in onze microdata niet voor.

15 Deze koppeltabel is door het Ministerie van OCW, de Inspectie van het onderwijs, SBB en de MBO Raad gezamenlijk samengesteld. Te vinden op http://www.kwalificatiesmbo.nl/crebo_overzichten.html.
} 
Voorbeeld 1: In instelling X wordt een opleiding tot basislasser aangeboden. Tot en met 2007 heeft deze opleiding binnen deze instelling de crebo-code 10126. Vanaf 2008 wordt de opleiding tot basislasser aangeboden onder crebo-code 94302 . Wij gaan er van uit dat de opleiding tot basislasser binnen deze instelling vanaf $\mathbf{2 0 0 8}$ is overgegaan op het kwalificatiedossier. Scholieren die in 2007 in de eindtermenopleiding zijn ingestroomd, krijgen volgens onze aanname vanaf 2008 mogelijkerwijs te maken met cgo.

Voorbeeld 2: Instelling Y biedt tot en met 2007 een aantal eindtermenopleidingen aan tot verspaner, die onder verschillende crebo-codes staan geregistreerd, te weten: 10101 (machinaal verspaner cnc), 10105 (machinebankwerker werktuigbouw), 10107 (machinaal verspaner), en 10109 (draaier). Vanaf 2008 wordt de opleiding tot verspaner aangeboden onder crebo-code $\mathbf{9 4 3 4 0 .}$. Wij gaan er van uit dat de opleiding tot verspaner binnen deze instelling vanaf 2008 is overgegaan op het kwalificatiedossier.

Voorbeeld 3: Aan instelling Z kunnen studenten zich laten opleiden tot monteur elektrotechnische installaties. Tot en met 2009 startten er eindtermenopleidingen, met crebo 10261. Vanaf 2008 start er echter ook een opleiding met crebo 94271. Wij gaan er van uit dat voor beide opleidingen geldt dat vanaf 2008 onderwijs een grotere kans heeft om te zijn ingericht volgens het cgo.

Onze tweede gegevensbron bevat individuele gegevens over de schoolprestaties van jongens en meisjes in het mbo afkomstig van de Dienst Uitvoering Onderwijs (DUO) van het Ministerie van Onderwijs. DUO verzamelt registers met gegevens over de schoolloopbaan en het schoolsucces van alle scholieren in Nederland. Uit deze databank gebruiken wij gegevens van alle scholieren die vanaf 2006 tot en met 2011 vanuit het vmbo zijn ingestroomd in een mbo-opleiding. De ons ter beschikking staande dataset bevat voor al deze scholieren informatie over het jaar van instroom, de instelling en de opleiding waarin zij zijn ingestroomd, of ze een diploma hebben behaald, en zo ja, in welk jaar. Daarnaast bevat het bestand een beperkte set achtergrondgegevens over de scholieren, zoals hun geslacht, hun leeftijd, en het niveau van de door hen gevolgde vmbo-opleiding.

We hebben bovengenoemde gegevensbronnen aan elkaar gekoppeld en geschoond. ${ }^{16}$ Deze exercitie levert een populatiedatabestand op waarin voor vrijwel alle opleidingen waarin scholieren tussen 2006 en 2011 bij de verschillende instellingen konden instromen bekend is in welk jaar men voor een bepaalde opleiding is overgegaan op competentiegerichte kwalificatiedossiers. Of en in hoeverre we redelijkerwijs kunnen aannemen dat studenten met het cgo in aanraking zijn geweest, hangt af van hun in- en uitstroomjaar. We kunnen in de populatie vier groepen studenten onderscheiden.

16 Een klein aantal initiële eindtermenopleidingen $\left(N_{\text {eebo }}=247\right)$ was niet op basis van beroep aan een competentiegericht dossier te koppelen; deze opleidingen worden daarom in de analyses niet meegenomen. Verder was het van $N_{\text {crebo }}=2.244$ eindtermenopleidingen $(11,8 \%)$ niet mogelijk na te gaan of er ooit het cgo is ingevoerd, en zo ja, wanneer. Ook deze opleidingen, waaraan in totaal $N_{i}=7.393$ scholieren $(1,3 \%)$ zijn ingestroomd, worden niet in de analyses meegenomen. 
- Studenten die instromen in een eindtermenopleiding en uitstromen of afstuderen op het moment vóór de overgang naar het cgo als onderwijsvorm. Deze studenten krijgen volgens onze aannames gedurende hun hele studieduur onderwijs dat is ingericht volgens de eindtermendossiers ( $N=7.622)$.

- Studenten die instromen ná de overgang krijgen volgens onze aannames alléén onderwijs dat gericht is op competentiedossiers. Dit is veruit de grootste groep $(N=452.904)$.

- Studenten die instromen vóór de overgang naar het cgo, maar uitstromen of afstuderen ná de invoer van het cgo. Deze studenten kunnen tijdens hun studie met beide onderwijsinrichtingen te maken hebben gehad ( $N=62.544)$.

- Studenten die instromen in een eindtermenopleiding, en waarvan op basis van de registerdata niet kan worden vastgesteld wanneer ze die opleiding verlaten. Van deze studenten konden wij niet vaststellen of en in hoeverre ze tijdens hun studie in aanraking zijn geweest met het cgo $(N=16.402)$. 


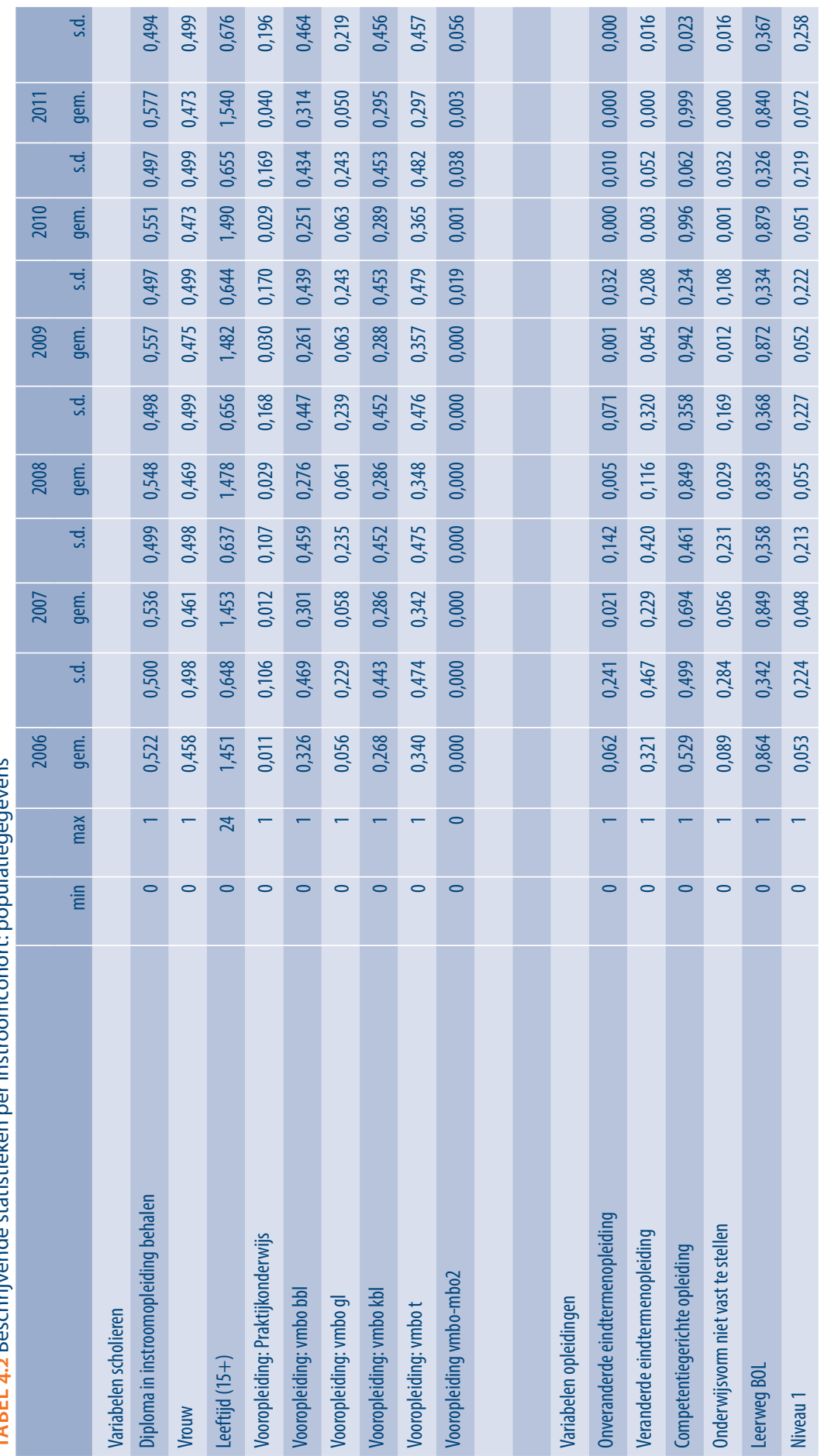




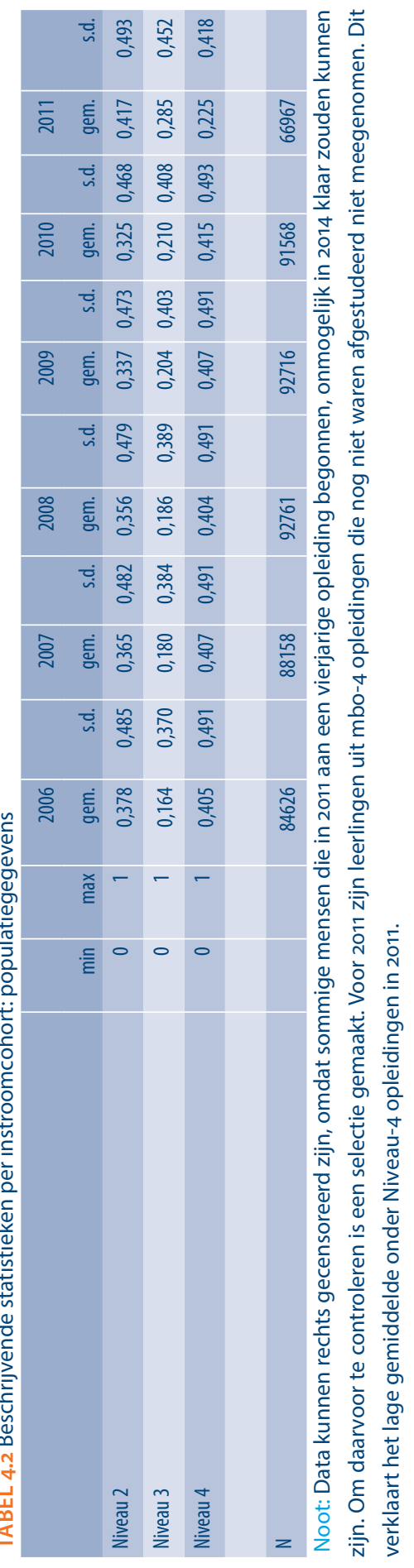

66 HOOFDSTUK 4 
De uiteindelijke populatiedataset bevat gegevens over $N_{i}=516796$ tussen 2006 en 2011 uit het vmbo instromende leerlingen uit $N_{\text {cohort }}=19633$ instroomcohorten van $N_{\text {crebo }}=4797$ opleidingen voor een beroep, aan $N_{b r i n}=70$ instellingen. Van deze leerlingen stroomde volgens onze bewerkingen $1,4 \%$ in in een onveranderde eindtermenopleiding, $11,6 \%$ in een eindtermenopleiding tijdens welke het cgo werd ingevoerd, en $84 \%$ in een opleiding waar de competentiegerichte kwalificatiedossiers werden ingevoerd. Voor $3 \%$ van de studenten was het niet mogelijk eenduidig vast te stellen of zijn tijdens hun studie met het cgo in aanraking zijn geweest.

Om na te gaan of en in hoeverre prestatieverschillen tussen jongens en meisjes in het mbo samenhangen met de invoer van competentiegerichte leeromgevingen voeren we een aantal analyses op de hiervoor omschreven data uit. Als meting van schoolsucces gebruiken we in deze analyses de kans om al dan niet een diploma te behalen in de opleiding waarin men ook is ingestroomd. Omdat die kans eerlijk te kunnen schatten, hebben we $\mathrm{N}=22676$ studenten die in 2011 zijn ingestroomd in een vierjarige opleiding en die dus in 2014 nog niet klaar konden zijn met die opleiding, buiten de analyse gelaten. Beschrijvende informatie over de achtergrondkenmerken van de verschillende cohorten is vermeld in tabel 4.2 .

FIGUUR 4.1 Percentage leerlingen dat diploma heeft gehaald in de opleiding waarin ze zijn ingestroomd

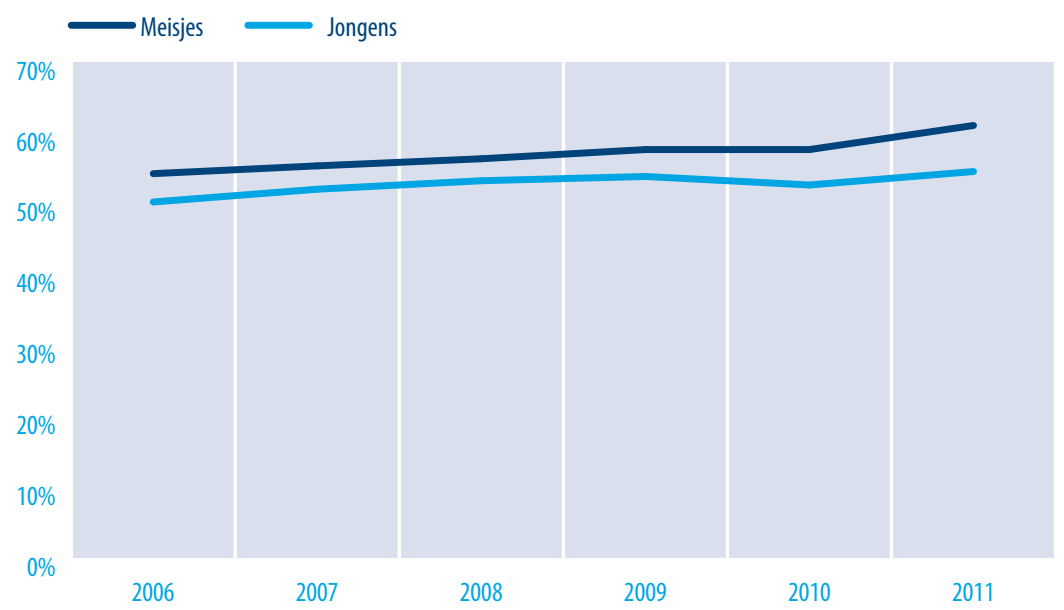

\subsection{Analyse en resultaten}

In figuur 4.1 presenteren we de slaagpercentages per instroomcohort. De figuur laat zien dat zowel jongens als meisjes het over de tijd het iets beter zijn gaan doen. Voor alle instroomcohorten geldt echter dat meisjes een hoger slaagpercentage hebben dan jongens. Ook lijkt de kloof tussen jongens en meisjes sinds 2009 te zijn toegenomen. 
Om na te gaan of jongens en meisjes een andere slaagkans hebben, voeren we een aantal regressieanalyses uit. Onze dataset kent een zogeheten hiërarchische structuur, waarbij leerlingen behoren tot een enkel instroomcohort van hun beroepsopleiding ${ }^{17}$, de instroomcohorten behoren tot een beroepsopleiding, en de beroepsopleidingen vallen onder een enkele instelling. Deze datastructuur is het best met een zogeheten multiniveau-analyse te analyseren (Snijders en Bosker, 2012)..$^{18}$

Verschillen in geobserveerde uitkomsten kunnen met de methode van de multiniveau-analyse worden toegeschreven aan specifieke eigenschappen van de vier analytische niveaus..$^{19}$ Het hoogste niveau betreft de instellingen. Met de toevoeging van dat niveau wordt het deel van de geobserveerde prestatieverschillen dat is toe te schrijven aan kenmerken van instellingen gemodelleerd. Een hiërarchisch niveau lager worden eigenschappen binnen instellingen en tussen beroepsopleidingen aan de vergelijking toegevoegd. We controleren op dit niveau voor kernmerken van beroepsopleidingen die niet gedurende de tijd veranderen, zoals de leerweg (BOL vs. BBL) en het kwalificatieniveau (1 vs. 2, 3 of 4 ).

Een niveau lager worden verschillen binnen beroepsopleidingen, maar tussen instroomcohorten gemodelleerd. Op dit niveau voegen we ook een aantal variabelen toe, die aangeven of studenten binnen deze beroepsopleiding startten in een veranderende eindtermenopleiding of een competentiegerichte opleiding. Door toevoeging van dit niveau wordt het mogelijk leerlingen te vergelijken die weliswaar binnen dezelfde instelling op dezelfde beroepsopleiding zitten, maar die doordat ze op een ander moment zijn ingestroomd, die opleiding volgen in andere leeromgevingen. Ook wordt gecontroleerd voor algemene, aan de voortschrijdende tijd toe te schrijven, verschillen in slaagkansen.

Het vierde en hiërarchisch gezien laagste niveau modelleert verschillen binnen instroomcohorten, tussen individuen. Op dit niveau wordt het geslacht van scholieren aan de vergelijking toegevoegd. We laten toe dat het effect van geslacht kan variëren tussen de instroomcohorten van beroepsopleidingen. ${ }^{20}$ Zo kunnen we nagaan of het effect van geslacht op de diplomakans systematisch varieert met het type opleiding. Op het individuele niveau controleren we bovendien voor een aantal persoonskenmerken, zoals de leeftijd bij instroom (in categorieën, waarbij de groep die op 15- of 16-jarige leeftijd instroomt de referentiegroep vormt) en het niveau van de vooropleiding. We voegen daartoe een aantal dummyvariabelen toe die het niveau van de vooropleiding

17 Daarmee bedoelen we in dit hoofdstuk: een opleiding die voor een bepaald beroep opleidt. Dit is een enkel abstractieniveau hoger dan het opleidingsniveau (crebo).

18 Om de analyses te kunnen draaien, hebben we een willekeurige steekproef van 10\% uit de populatiedata getrokken. We hebben deze data geanalyseerd met een 4-niveau logistische random slope regressieanalyse, waarbij we de hierboven beschreven kenmerken regresseren op de odds een diploma te halen in de instroomopleiding. We gebruikten daarvoor het statistische programma stata 12, en binnen dat programma het pakket xtmelogit, dat speciaal voor dit soort analyses is ontworpen. We gebruiken adaptieve kwadratuur processen met één integratiepunt (ook wel: Laplace-benadering) om de vier-niveau logistische modellen te kunnen schatten (Rabe-Hesketh en Skodral, 2005)

19 De niveaus hebben elk een eigen variantiecomponent

20 We schatten dus een random slope voor vrouwen op het niveau van instroomcohorten binnen opleidingen 
weergeven. We onderscheiden scholieren die praktijkonderwijs hebben gevolgd van scholieren die beroepsbegeleidende leerwegen, kaderberoepsgerichte leerwegen, gemengde leerwegen, theoretische leerwegen, en mbo-2 doorstroomopleidingen hebben afgerond. Mensen met een vmbo-t-diploma zijn de referentiegroep.

TABEL 4.3 Multiniveau logistische regressieanalyse op de kans een diploma te halen in de instroomopleiding

\begin{tabular}{|c|c|c|c|c|c|}
\hline & Model 1 & Model 2 & Model 3 & Model 4 & Model 5 \\
\hline Intercept & $0.209^{* * *}$ & $0.406^{* * *}$ & $0.674^{* * *}$ & $0.549^{* * *}$ & $0.538^{* * *}$ \\
\hline \multicolumn{6}{|l|}{ Kernvariabelen } \\
\hline Meisjes (jongens zijn ref.) & $0.118^{* * * *}$ & $0.102^{* * *}$ & $0.171^{* * *}$ & $0.165^{* * *}$ & $0.184^{* * *}$ \\
\hline Kwalificatiedossiers & & & & Ref. & Ref. \\
\hline Onveranderde eindtermen & & & & $1.221^{* * *}$ & $1.333^{* * *}$ \\
\hline Veranderde eindtermen & & & & $0.497^{* * *}$ & $0.572^{* * *}$ \\
\hline Veranderde eindtermen*meisjes & & & & & -0.326 \\
\hline Onveranderde eindtermen ${ }^{*}$ meisjes & & & & & $-0.154^{*}$ \\
\hline \multicolumn{6}{|l|}{ Controlevariabelen } \\
\hline Leeftijd bij instroom (15=ref). & & $\sqrt{ }$ & $\sqrt{ }$ & $\sqrt{ }$ & $\sqrt{ }$ \\
\hline Niveau vmbo-opleiding ( $t=r e f$ ) & & $\sqrt{ }$ & $\sqrt{ }$ & $\sqrt{ }$ & $\sqrt{ }$ \\
\hline Kwalificatieniveau (4=ref) & & & $\sqrt{ }$ & $\sqrt{ }$ & $\sqrt{ }$ \\
\hline Leerweg (BOL=ref.) & & & $\sqrt{ }$ & $\sqrt{ }$ & $\sqrt{ }$ \\
\hline \multicolumn{6}{|l|}{ Random Intercepten } \\
\hline Instellingen & $0.183^{* * *}$ & $0.186^{* * *}$ & $0.188^{* * *}$ & $0.165^{* * *}$ & $0.165^{* * *}$ \\
\hline Tussen beroepsopleidingen binnen instellingen & $0.589^{* * *}$ & $0.603^{* * *}$ & $0.554^{* * *}$ & $0.554^{* * *}$ & $0.554^{* * *}$ \\
\hline $\begin{array}{l}\text { Tussen instroomcohorten binnen } \\
\text { beroepsopleidingen }\end{array}$ & $0.283^{* * *}$ & $0.287^{* * *}$ & $0.286^{* * *}$ & $0.263^{* * *}$ & $0.265^{* * *}$ \\
\hline \multicolumn{6}{|l|}{ Random slopes } \\
\hline Vrouwen tussen instroomcohorten & $0.130^{* * *}$ & $0.120^{*}$ & $0.136^{*}$ & $0.154^{* * *}$ & $0.140^{* * *}$ \\
\hline
\end{tabular}

Noten. Op een willekeurige steekproef van 10\% van de populatie (51615 individuen in 12604 instroomcohorten, in 3802 beroepsopleidingen, in 68 instellingen). ${ }^{*} p<0.05,{ }^{* *} p<0.01,{ }^{* * *} p<0.001$. Bronnen: BRON-data.

De resultaten van deze verklarende analyse worden gepresenteerd in tabel 4.3. In model 1 presenteren we de geschatte verschillen tussen jongens en meisjes, wanneer we rekening houden met algemene instellingsverschillen, verschillen tussen beroepsopleidingen, tussen instroomcohorten en tussen leerlingen. Wanneer we met deze verschillen 
rekening houden, observeren we dat meisjes een hogere kans hebben een diploma in hun instroomstudie te halen dan jongens. ${ }^{21}$ In model 2 voegen we individuele kenmerken toe. Uit dit model blijkt dat het verschil tussen jongens en meisjes niet te verklaren is door verschillen in instroomleeftijd of niveauverschillen van de vooropleiding. In model 3 wordt vervolgens een aantal algemene opleidingskenmerken toegevoegd. Dit model laat zien dat verschillen tussen jongens en meisjes niet worden verklaard doordat de opleidingen waaraan jongens en meisjes studeren verschillen in het kwalificatieniveau of de leerweg. Sterker nog, wanneer we controleren voor deze kenmerken is de slaagkans van meisjes zelfs hoger. ${ }^{22}$

In model 4 worden twee dummy's toegevoegd die de mate aangeven waarin mensen die studeren aan een competentiegerichte opleiding (de referentiegroep) het beter doen dan mensen aan een (al dan niet veranderende) eindtermenopleiding, gecontroleerd voor individuele kenmerken en andere opleidingskenmerken. Dit model maakt aannemelijk dat verschillen tussen jongens en meisjes slechts gedeeltelijk verklaard worden doordat meisjes vaker dan jongens in opleidingen met een voor hen gunstige onderwijsvormen zitten. Met andere woorden, de kwalificatiedossiers zijn in vrijwel gelijke mate ingevoerd in typische mannenopleidingen als typische vrouwenopleidingen. ${ }^{23}$

21 Bovendien zien we dat het grootste deel van de totale verschillen in gediplomeerd uitstromen uit de instroomopleiding verklaard wordt door verschillen tussen de verschillende beroepsopleidingen (0.589).

22 Met andere woorden, er treedt een suppresor-effect omdat meisjes meer instromen in opleidingen (qua leerweg en niveau) die een relatief lage slaagkans hebben.

23 Het lijkt er ook op dat scholieren het gemiddeld genomen aan cgo-opleidingen minder goed doen dan aan veranderde en onveranderde eindtermenopleidingen. Dit wordt deels veroorzaakt door het feit dat instromers in de eindtermenopleidingen langer de tijd hebben gehad om een diploma te halen dan instromers in de competentiegerichte opleidingen, omdat die laatsten later gestart zijn. We controleren slechts gedeeltelijk voor dit soort rechts-censorering van de data, omdat we alleen de mensen die een opleiding logischerwijs niet hebben kunnen afmaken buiten beschouwing laten. De verschillen worden verder vergroot doordat we alleen mensen van wie we met zekerheid konden vaststellen dat ze gedurende hun volledige opleidingstijd eindtermenopleidingen hebben gevolgd als zodanig hebben gecategoriseerd, en mensen die in eindtermenopleidingen zijn ingestroomd maar waarvan we niet kunnen vaststellen of ze in eindtermenopleidingen een diploma hebben gehaald als aparte beschouwen. Aanvullende analyses laten zien dat de censorering de conclusies over verschillen tussen jongens en meisjes niet substantieel beïnvloedt. 
FIGUUR 4.2 Kans om diploma te halen in de opleiding waarin jongens en meisjes zijn ingestroomd, gedifferentieerd voor eindtermenopleidingen en opleidingen waar het cgo is ingevoerd* $^{*}$

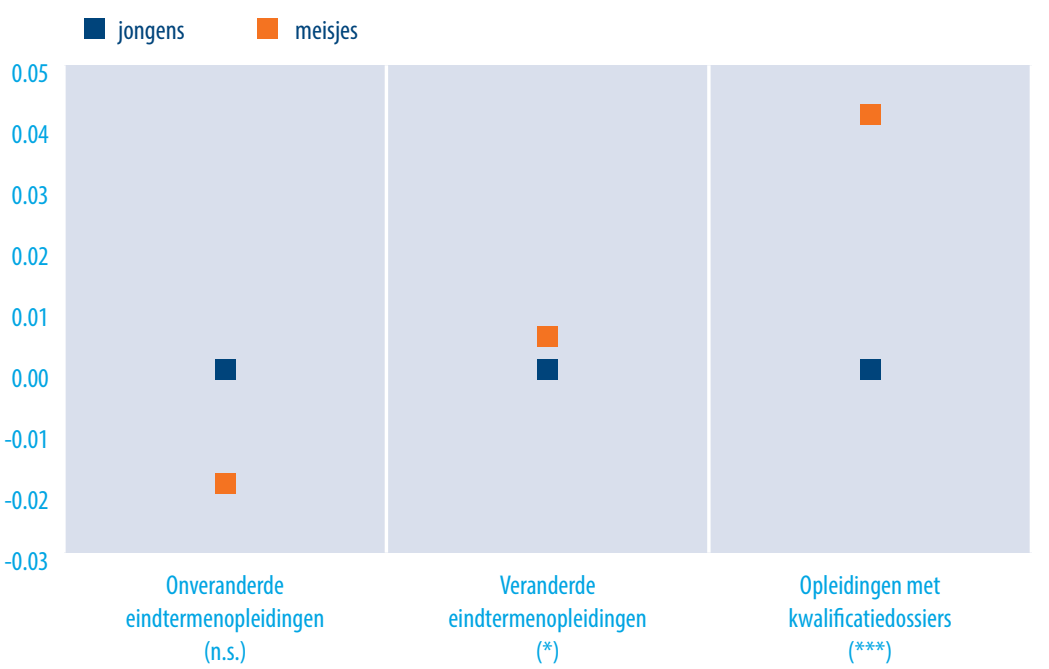

*Noot: schattingen van interactie-effecten zijn gecontroleerd voor niveau van vooropleiding, leeftijd van scholieren bij instroom, alsook het kwalificatieniveau en de leerweg van de opleiding.

Maar heeft de invoer van competentiegerichte kwalificatiedossiers nu een ander effect op jongens dan op meisjes? Om daar een beter antwoord op te geven, schatten we in model 5 een model met interactie-effecten tussen geslacht en de verschillende opleidingsvormen. Uit de sterkte en de richting van deze interactie-effecten blijkt of en in hoeverre het verband tussen les krijgen in een competentiegerichte leeromgeving en schoolprestaties anders is voor jongens dan voor meisjes. Als meisjes meer baat zouden hebben bij competentiegerichte leervormen, dan zou het netto-effect voor meisjes sterker positief moeten zijn dan voor jongens. Dat blijkt zo te zijn. De cijfers uit de tabel zijn wat lastig te interpreteren, omdat alle coëfficiënten relatief zijn ten opzichte van de referentiegroep (in dit geval: jongens in competentiegerichte leeromgevingen). De interactie wordt daarom geïllustreerd in figuur 4.2. De figuur bevat relatieve slaagkansen van jongens en meisjes die instroomden in opleidingen die volledig volgens de competentiegerichte dossiers waren ingericht, eindtermenopleidingen die tijdens curricula van onderwijsvorm gewisseld zouden kunnen zijn, en opleidingen die volledig volgens de eindtermendossiers waren (en bleven) ingericht. Jongens vormen voor iedere opleidingsvariant de referentiegroep. In eindtermenopleidingen doen jongens het iets beter dan meisjes, maar de verschillen zijn niet significant. Meisjes doen het duidelijk beter dan jongens in opleidingsvarianten die zijn gebaseerd op competentiegerichte kwalificatieprofielen. Hoewel direct moet worden opgemerkt dat het interactie-effect klein is, bieden deze bevindingen een duidelijke ondersteuning van de veronderstelling dat meisjes het in competentiegerichte leeromgevingen beter doen dan jongens. 


\subsection{Conclusies}

In dit hoofdstuk zijn we nagegaan of prestatieverschillen tussen jongens en meisjes in het Nederlandse middelbaar beroepsonderwijs zijn toe te schrijven aan de competentiegerichte leeromgevingen die de afgelopen jaren zijn ingevoerd in het mbo. We koppelden daartoe een unieke dataset over de invoer van competentiegerichte kwalificatiedossiers in het mbo aan registerdata over de opleidingsresultaten van meer dan een half miljoen mbo-scholieren die tussen 2006 en 2011 vanuit het vmbo instroomden.

Alvorens conclusies te trekken is een woord van voorzichtigheid gepast. De gebruikte gegevens over opleidingen zijn de meest betrouwbare beschikbare gegevens op dit gebied. Desondanks is een voorbehoud bij de interpretatie van de modellen die in dit hoofdstuk worden gepresenteerd op zijn plaats. De door ons gedane aanname dat de invoer van de kwalificatiedossiers gelijk valt met de invoering van competentiegerichte didactiek moet om twee redenen worden gekwalificeerd.

Een eerste voorbehoud hangt samen met de timing van de beleidswijzigingen. Steekproefonderzoek maakt aannemelijk dat het moment van invoer van kwalificatiedossiers in iets meer dan een vijfde deel van de opleidingen niet één-op-één overeen met het moment van invoer van competentiegerichte leervormen (Van der Meijden et al., 2013). Het is op basis van deze gegevens helaas niet vast te stellen om welke opleidingen het gaat. Ten tweede is de term "competentiegericht onderwijs" een vele ladingen dekkende vlag, en is niet direct duidelijk hoe de term door de verschillende opleidingen is geïnterpreteerd (Van der Meijden et al., 2013). Opleidingen hebben een grote mate van autonomie gekregen bij de bepaling van de wijze waarop de kwalificatiedossiers een weerslag zouden vinden in hun respectievelijke curricula. Het is dan ook niet zo, dat de invoer van het cgo in het Nederlandse mbo heeft geleid tot een verschuiving naar een enkele, helder te definiëren onderwijsvorm (Van der Meijden en Pétit, 2014). Focusgroeponderzoek onder onderwijzend personeel dat betrokken was bij de invoer van de kwalificatiedossiers maakt evenwel aannemelijk dat zich desondanks een algemene verandering heeft voorgedaan, waarin traditioneel klassikaal onderwijs een minder prominente rol heeft gekregen ten faveure van een breed scala aan andere aanpakken (Van der Meijden en Pétit, 2014). Deze andere aanpakken lijken als gemene deler te hebben dat ze een grotere mate van zelfstandigheid van leerlingen verwachten, contextrijkere leeromgevingen bieden, alsook minder lineaire en meer op procesbegeleiding gerichte onderwijsvormen veronderstellen. Volgens de theorie gedijen meisjes in dergelijke leeromgevingen beter.

Deze voorbehouden in acht nemende, laten de analyses zien dat er geen significant verschil is in de slaagkans van jongens en meisjes in de door ons geanalyseerde eindtermenopleidingen, maar ook dat meisjes het op opleidingen waar de competentiegerichte kwalificatiedossiers zijn ingevoerd beter doen dan jongens. We trekken deze conclusie op basis van een vergelijking van prestatiegegevens van mensen die bij een bepaalde beroepsopleiding aan een bepaalde instelling zijn ingestroomd, met de gegevens van vergelijkbare mensen die op een later moment in dezelfde beroepsopleid- 
ing bij dezelfde instelling zijn ingestroomd. De geobserveerde verschillen zijn niet toe te schrijven aan algemene trends, aan verschillen in individuele kenmerken, of aan andere instellings- of opleidingskenmerken. Onze multivariate analyses bieden dus een duidelijke ondersteuning voor de aanname dat meisjes het in competentiegerichte leeromgevingen beter doen dan jongens, en daarmee dat de betere prestaties van meisjes in het mbo te verklaren zijn door de invoer van competentiegericht onderwijs.

\section{KERNCONCLUSIES}

- Meisjes behalen vaker dan jongens een diploma in de opleiding waarin ze zijn ingestroomd als die opleiding is ingericht volgens competentiegerichte kwalificatiedossiers

- Jongens behalen vaker dan meisjes een diploma in hun instroomopleiding als die opleiding is ingericht volgens eindtermen

- Het is dan ook aannemelijk dat de betere prestaties van meisjes ten opzichte van jongens in het Nederlandse mbo voor een deel kunnen worden verklaard door de invoering van de competentiegerichte kwalificatiedossiers 


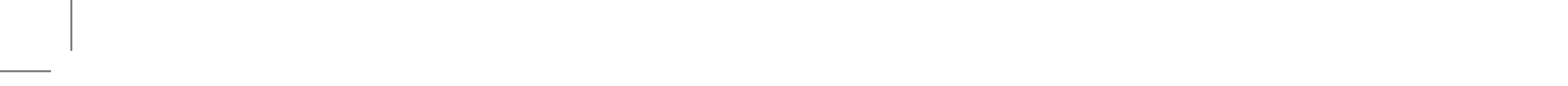




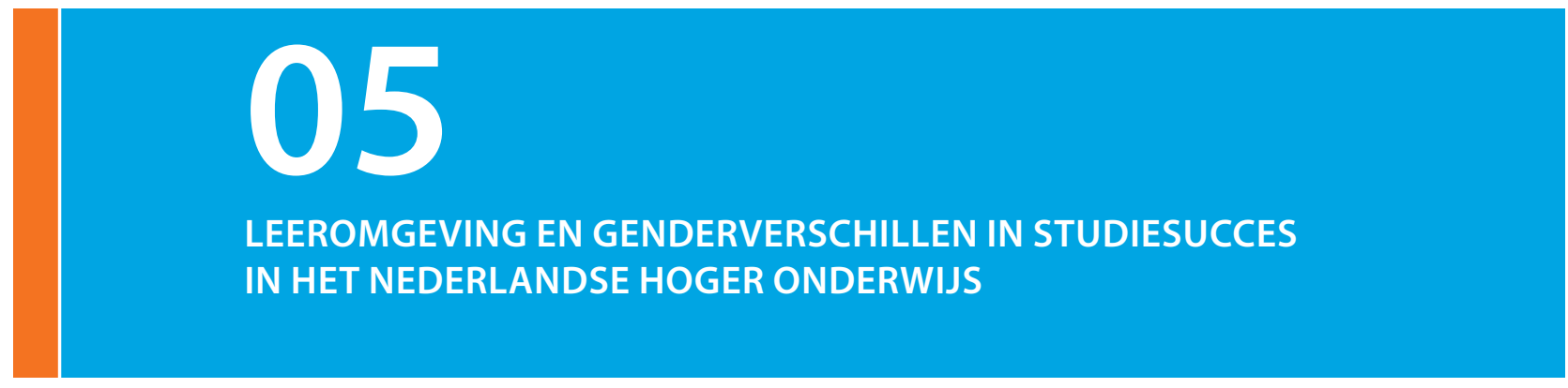

\section{Christoph Meng \\ (Researchcentrum voor Onderwijs en Arbeidsmarkt)}

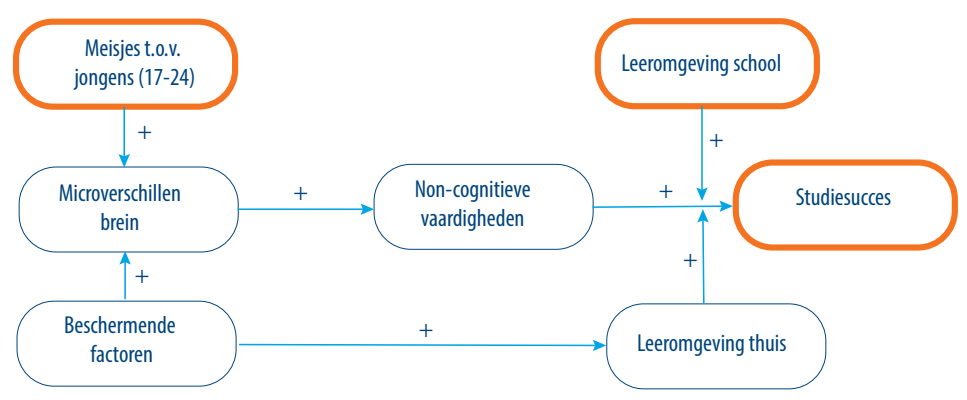

\section{Samenvatting}

In dit hoofdstuk gaan we in op de vraag of meisjes hogere afstudeercijfers in het hoger onderwijs halen en de studie verlaten met een hoger niveau aan zelf gerapporteerde competenties. Afstudeercijfers, maar vooral ook een hoog niveau aan competenties, worden immers vaak als belangrijke factor voor arbeidsmarktsucces gezien. Centraal in onze vraagstelling is daarbij de rol van de leeromgeving in het hoger onderwijs. We analyseren hiervoor een unieke dataset (REFLEX) met daarin gegevens van bijna 3.500 respondenten afkomstig van het HBO en het WO. De REFLEX data biedt ons de mogelijkheid om de leeromgeving te typeren aan de hand van een tweetal factoren, namelijk a) de nadruk die ligt op project-/probleemgestuurd onderwijs en b) de nadruk die ligt op de rol van de docent als belangrijkste informatiebron.

Wat het afstudeercijfer betreft laten de resultaten laten zien dat in het WO geen significante verschillen zijn tussen jongens en meisjes. In het $\mathrm{HBO}$ is dat wel gedeeltelijk het geval. Meisjes doen het in het HBO daarbij vooral beter in situaties waarin van de student een actieve rol verwacht wordt en de docent geen centrale rol als bron van informatie is.

Wat de competenties betreft vinden we dat het niveau van competenties of niet verschilt tussen jongens en meisjes, of in het geval van academische vaardigheden, voor meisjes 
deels zelfs lager uitvalt. Met andere woorden, het hogere afstudeercijfer vertaalt zich niet in hogere niveaus van competenties.

\subsection{Inleiding}

In het hoofdstuk 4 stond het onderwijssucces van jongens en meisjes in het middelbaar beroepsonderwijs centraal. In dit hoofdstuk vervolgen we ons onderzoek maar richten ons nu op het hoger onderwijs. Meisjes zijn in de regel succesvoller in het Nederlandse hoger onderwijs dan jongens. Deze stelling wordt vaak onderbouwd door te kijken naar rendement cijfers zoals weergegeven in Tabel 5.1. Meisjes halen vaker een diploma, maken minder vaak een switch tussen studiedomein of HOOP gebied tijdens hun studieloopbaan en vallen minder vaak uit zonder diploma. Ook ronden ze hun studie in de regel sneller af dan jongens. Deze uitkomsten gelden zowel voor jongeren die in het HBO als in het WO met hun studie starten. Opvallend is dat het hogere studiesucces van meisjes zich in de regel niet direct vertaald in een betere start op de arbeidsmarkt of een beter verloop van de arbeidsmarktloopbaan (zie OCW, 2014).

TABEL 5.1 Studiesucces in het Hoger onderwijs (cohort 2005)

\begin{tabular}{|c|c|c|c|c|c|}
\hline & Diploma & Switch & Uitval & $\begin{array}{c}\text { Duur tot eerst } \\
\text { diploma (in jaren) }\end{array}$ \\
\hline HBO & Jongens & $59 \%$ & $22 \%$ & $30 \%$ & 4,7 \\
\hline \multirow{2}{*}{ W0 } & Meisjes & $71 \%$ & $17 \%$ & $21 \%$ & 4,4 \\
\hline & Jongens & $68 \%$ & $19 \%$ & $19 \%$ & 4,3 \\
\hline
\end{tabular}

Bron: Ministerie van OCW (2014)

De cijfers in Tabel 5.1 kunnen erop wijzen dat meisjes betere studiekeuzes maken dan jongens. Het is in dit kader dan ook interessant om te kijken of meisjes achteraf minder spijt hebben van de gekozen studie in het hoger onderwijs. ${ }^{24}$ Figuur 5.1 laat voor de afgestudeerden van het HBO (gemeten anderhalf jaar na behalen van het diploma) het percentage meisjes en het percentage jongens zien dat achteraf bezien niet meer dezelfde studie zou kiezen. Gemiddeld heeft in de periode 2001 tot en met 2014 zo'n 20\% van de afgestudeerden achteraf spijt van de destijds gekozen studie. Wat een eventueel verschil tussen jongens en meisjes betreft, laat Figuur 5.1 een tweetal conclusies toe:

- In geen van de onderzochte meetjaren is het verschil tussen jongens en meisjes groter dan 2,5\%-punt. In de meeste jaren is het verschil zelfs maximaal 1\%-punt;

- Tot en met meetjaar 2006 lijken de meisjes achteraf iets minder spijt van de studiekeuze te hebben. Vanaf meetjaar 2011 lijken de meisjes achteraf iets meer spijt van de studiekeuze te hebben.

24 De lezer dient zich daarbij te realiseren dat de HBO Monitor afgestudeerden bevraagd. Jongeren die wegens een verkeerde studiekeuze het HBO zonder diploma verlaten zijn daarom niet in de bevraging opgenomen. 
Op basis van de 'spijtvraag' zoals gesteld in de HBO-Monitor kan dan ook niet vastgesteld worden dat meisjes een betere studiekeuze maken dan jongens of dat hierin een duidelijke verandering in de afgelopen 15 jaar heeft plaatsgevonden.

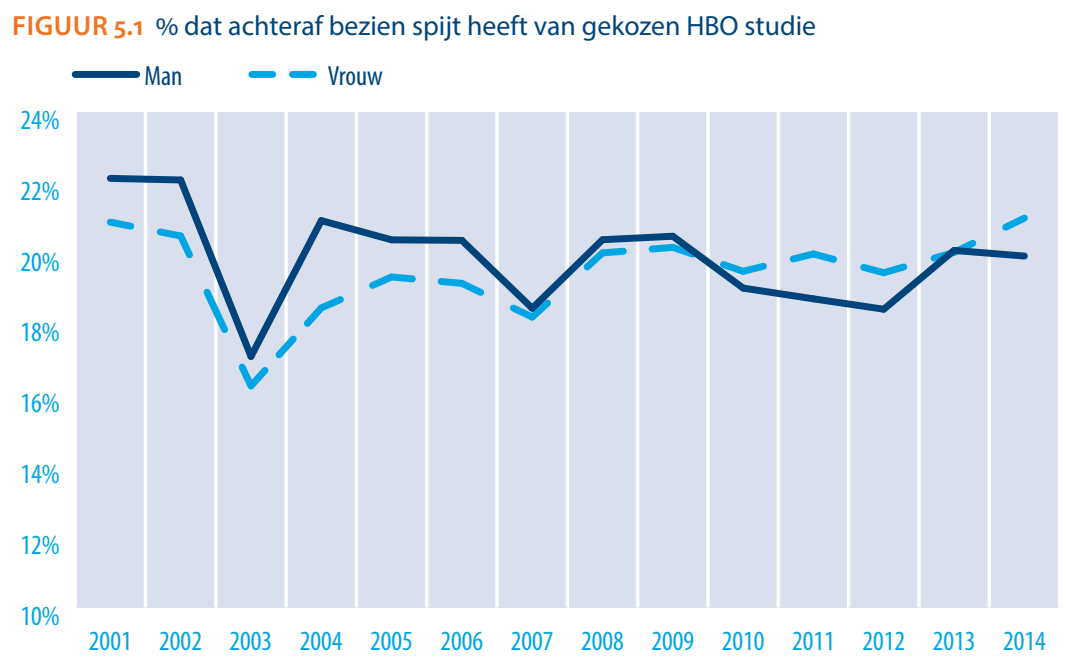

In dit deelproject gaan we nader op dit verschil in studiesucces in, en onderzoeken we of meisjes ook a) hogere afstudeercijfers halen en b) de studie verlaten met een hoger niveau aan competenties. Afstudeercijfers, maar vooral ook een hoog niveau aan competenties, worden immers vaak als belangrijke factor voor arbeidsmarktsucces gezien. Centraal in onze vraagstelling is daarbij de rol van de leeromgeving in het hoger onderwijs. De afgelopen decennia heeft de toenemende kritiek op traditionele onderwijsmethoden in het hoger onderwijs geleid tot een brede invoering van activerende leermethoden, zoals probleemgestuurd en competentiegericht onderwijs en projectonderwijs, waarbij de student centraal wordt gesteld en van hem/haar wordt verwacht dat hij/zij een actieve ontdekker is in plaats van iemand die passief informatie ontvangt. Eerder onderzoek heeft aangetoond dat activerende leeromgevingen inderdaad invloed hebben op het type en het niveau van competenties die studenten aan het einde van de studie bezitten (Vaatstra en De Vries, 2007; Meng, 2006; Van der Velden \& Allen, 2011). Studenten afkomstig van activerende leeromgevingen bezitten in de regel een hoger niveau aan bepaalde generieke competenties, die in de context van de discussie over $21^{\text {st }}$ century skills vaak als cruciaal voor arbeidsmarktsucces gezien worden, zonder dat dit ten koste gaat van de vakkennis die zij aan het einde van de studie bezitten (Meng, 2006). In dit deelproject willen we deze vraag verder analyseren door na te gaan of verschillende leeromgevingen verschillende effecten op het studiesucces voor jongens en meisjes hebben. De gedachte daarachter is dat activerende leeromgevingen voor jongeren in de laatadolescentie beter passen bij meisjes dan bij jongens, en dat dit een reden kan zijn voor het hogere studiesucces van de meisjes. Studiesucces wordt daarbij gedefinieerd aan 
de hand van het gemiddelde afstudeercijfer en aan de hand van het type en niveau van competenties die de afgestudeerden 5 jaar na behalen van het diploma bezitten.

We analyseren hiervoor een unieke dataset afkomstig van een Europees afgestudeerdenonderzoek (REFLEX) welke in 2005/2006 in 14 Europese landen heeft plaatsgevonden. Dit meetmoment was 5 jaar nadat de respondenten het diploma hadden behaald. In Nederland hebben bijna 3.500 respondenten (1.134 respondenten afkomstig van het WO en 2.291 respondenten van het $\mathrm{HBO}$ ) deelgenomen.

De REFLEX data biedt ons de mogelijkheid om de leeromgeving te typeren aan de hand van een tweetal factoren:

1) De nadruk die ligt op project-/probleemgestuurd onderwijs

2) De nadruk die ligt op de rol van de docent als belangrijkste informatiebron

Respondenten dienden voor beide factoren aan te geven in hoeverre dat in hun studieprogramma benadrukt werd. Het antwoord kon gegeven worden op een 5-punt Likert schaal ( 1 'helemaal niet' tot 5 ' in zeer hoge mate'). Analoog aan eerder onderzoek (Meng, 2006) worden de antwoordopties 4 en 5 getypeerd als '(sterke) nadruk' getypeerd en de antwoordopties 1 tot en met 3 als 'geen nadruk'.25 Op basis van deze twee vragen onderscheiden we een viertal leeromgevingen:

FIGUUR 5.2 : Leeromgevingen in het Nederlandse hoger onderwijs

\begin{tabular}{|c|c|l|l|}
\hline & & \multicolumn{2}{|c|}{ Docent als centrale bron van informatie } \\
\hline & & \multicolumn{1}{|c|}{ Ja } & \multicolumn{1}{c|}{ Nee } \\
\hline \multirow{3}{*}{ Project-/probleemgestuurd onderwijs } & Ja & $\begin{array}{l}\text { Docentgericht met project-/ } \\
\text { probleemgestuurd (1) }\end{array}$ & $\begin{array}{l}\text { Studentgericht met project-/ } \\
\text { probleemgestuurd (2) }\end{array}$ \\
\cline { 2 - 4 } & Nee & $\begin{array}{l}\text { Docentgericht zonder project-/ } \\
\text { probleemgestuurd (3) }\end{array}$ & $\begin{array}{l}\text { Studentgericht zonder project-/ } \\
\text { probleemgestuurd (4) }\end{array}$ \\
\hline
\end{tabular}

Leeromgeving 2 ( $25 \%$ van de respondenten) en $4(40 \%)$ zijn beide studentgericht, waarbij leeromgeving 2 dit combineert met project-/probleemgestuurd onderwijs. In leeromgeving (2) en (4) is de studie dan ook sterk gebaseerd op zelfdiscipline van studenten en het vermogen van studenten om zelf op onderzoek uit te gaan en zich de vereiste competenties eigen te maken. De docent is in deze context meer een moderator en begeleider van het proces dan de bron van informatie. Leeromgevingen 1 (9\%) en $3(25 \%)$ zijn docentgericht, waarbij leeromgeving 1 dit combineert met project-/ probleemgestuurd onderwijs. In deze twee leeromgevingen wordt minder nadruk op het eigen initiatief van de student gelegd en speelt de docent een nadrukkelijke rol als bron van informatie. Op basis van het REFLEX-project kan worden vastgesteld dat eind jaren negentig de nadruk op project-/probleemgestuurd onderwijs in de onderzochte groep vaker vermeld werd door de afgestudeerden van het $\mathrm{HBO}(42 \%)$ dan door

25 Aanvullende analyses (niet weergegeven in dit hoofdstuk)laten zien dat een eventueel andere typering ( 1 en 2 versus 3,4 en 5) geen invloed heeft op de hier gepresenteerde resultaten. 
de afgestudeerden van het WO (22\%). Tussen vrouwelijke en mannelijke respondenten (gecontroleerd voor het type hoger onderwijs) doen zich geen verschillen voor.

\subsection{Studiesucces: gemiddeld afstudeercijfer}

De centrale onderzoeksvraag in dit deelproject is of a) meisjes gemiddeld hogere afstudeercijfers hebben en b) of de eventuele voorsprong van meisjes afhankelijk is van de leeromgeving. De verwachting is dat meisjes beter presteren in situaties waar zij actief op zoek dienen te gaan en waarin de noodzakelijke informatie niet rechtstreeks door de docent geboden wordt (studentgerichte leeromgevingen). Om dit te testen, kijken we naar het door de respondent gerapporteerde gemiddelde afstudeercijfer in de studie die hij of zij in het HBO dan wel in het WO heeft gevolgd. ${ }^{26}$

Om het verschil tussen het afstudeercijfer van jongens en meisjes vast te stellen is een aantal analyse ${ }^{27}$ uitgevoerd met het gemiddelde afstudeercijfer als afhankelijke variabele. In alle analyses is, waar van toepassing, gecontroleerd voor type hoger onderwijs (HBO versus WO) studierichting (sector), type vooropleiding (VWO, HAVO, overig), gemiddeld eindexamencijfer in vooropleiding, werkervaring voor en tijdens de gevolgde studie, vrijwilligerswerk en werkzaamheden in studentenorganisaties, geboorteland van de respondent zelf evenals het geboorteland van de ouders van de respondent. Tabel 5.2 presenteert de centrale uitkomst van de analyses (de coëfficiënt voor de dummy 'vrouwelijk respondent'). Kolom 1 laat de uitkomst zien voor respondenten onafhankelijk van de leeromgeving. Kolom 2 tot en met 5 laten de uitkomsten zien voor de 4 onderscheiden leeromgevingen. In elke kolom worden daarbij de resultaten van een drietal analyses gepresenteerd, namelijk a) voor alle respondenten (HBO en WO, waarbij in de analyse voor het type hoger onderwijs is gecontroleerd), b) voor de respondenten die een HBO studie gevolgd hebben en c) voor de respondenten die een WO studie gevolgd hebben..$^{28}$

TABEL 5.2 OLS regressie op afstudeercijfer: coëfficiënt voor vrouwen

\begin{tabular}{|l|c|c|c|c|c|}
\hline & Alle leeromgevingen & Leeromgeving (1) & Leeromgeving (2) & Leeromgeving (3) & Leeromgeving (4) \\
\hline HB0 en W0 & $0.161^{* * *}$ & 0.152 & $0.228^{* * *}$ & 0.102 & $0.203^{* * *}$ \\
\hline HBO & $0.201^{* *}$ & 0.186 & $0.297^{* * *}$ & 0.186 & $0.213^{* *}$ \\
\hline W0 & 0.105 & 0.248 & -0.002 & 0.040 & $0.190^{*}$ \\
\hline
\end{tabular}

Bron: REFLEX; ******* significant van nul verschillend op 10\%/5\%/1\% niveau

De resultaten laten zien dat in het WO geen significante verschillen zijn tussen jongens en meisjes. In het HBO is dat bij een drietal analyses wel het geval. Meisjes doen het in het

26 Het onderzoek heeft betrekking op het diploma dat de afgestudeerden in het studiejaar 2000-2001 hebben behaald. Het betreft hierbij diploma's in het oude systeem voordat in Nederland het Bachelor-Master systeem is ingevoerd.

27 In meer detail betreft het hierbij multivariate ordinary least square (OLS) analyses.

28 Aanvullende analyses laten zien dat wat het gemiddeld afstudeercijfer betreft er geen significante verschillen te vinden zijn tussen de 4 onderscheiden leeromgevingen. 
$\mathrm{HBO}$ daarbij vooral beter in de studentgerichte leeromgeving met project-/probleemgestuurde activiteiten (2) en de studentgerichte leeromgeving zonder project-/probleemgestuurde activiteiten (4). De uitkomsten van hogere afstudeercijfers van meisjes in het HBO lijken daarmee niet een effect van project-/probleemgestuurd onderwijs te zijn, maar meisjes lijken vooral beter te presteren in situaties waarin van de student een actieve rol verwacht wordt en de docent geen centrale rol als bron van informatie is.

\subsection{Competenties}

Meisjes ronden hun studie met een hoger afstudeercijfer af dan jongens, althans in het $\mathrm{HBO}$ en wanneer er sprake is van een studentgerichte leeromgeving. De vraag is of zich dit ook vertaald in een hoger niveau aan competenties. In het kader van dit onderzoek wordt deze vraag op een tweetal plekken geanalyseerd: in dit hoofdstuk op basis van zelf gerapporteerde competenties in de REFLEX data en in hoofdstuk 6 op basis van testen uitgevoerd in het kader van het Programme for the International Assessment of Adult Competencies (PIAAC).

Wat de analyses op basis van het REFLEX databestand betreft, dienen we met het volgende probleem rekening te houden. Het niveau van de competenties is in het REFLEX-project bepaald op basis van een zelfoordeel van de respondent. Hierdoor ontstaat een mogelijke bias als gevolg van systematische over- of onderschatting. In het kader van het huidige project is dat vooral een probleem indien deze bias structureel verschilt tussen jongens en meisjes, bijvoorbeeld omdat jongens systematisch hun competenties overschatten. We zullen daarvoor in de huidige analyse proberen te corrigeren, maar het probleem kan nooit helemaal opgelost worden. De bevindingen in deze paragraaf dienen daarom vergeleken te worden met de bevindingen op basis van de objectieve tests zoals uitgevoerd in het kader van PIAAC om de resultaten te valideren.

Respondenten zijn in het kader van het REFLEX project gevraagd om op een 19-tal items (vaardigheden/competenties) aan te geven wat het eigen niveau is. Op basis van cluster- en factoranalyses en op basis van eerder onderzoek (zie bijvoorbeeld Meng, 2006) is ervoor gekozen om uiteindelijk een drietal clusters van competenties nader te onderzoeken:

1. Vakkennis

- Beheersing van uw eigen vakgebied of discipline

2. Coördinerend en samenwerkend vermogen (Cronbach's Alpha: 0.67$)$

- Vermogen om activiteiten te coördineren

- Vermogen om effectief te onderhandelen

- Vermogen om productief met anderen samen te werken

- Vermogen om de capaciteiten van anderen aan te spreken 
3. Academische vaardigheden (Cronbach's Alpha: 0.74)

- Analytisch denken

- Vermogen om snel nieuwe kennis op te doen

- Alert zijn op nieuwe mogelijkheden

- Vermogen om nieuwe ideeën en oplossingen te bedenken

- Bereidheid om ideeën van uzelf en van anderen ter discussie te stellen

Analyses laten zien dat cluster 2 en 3 wat de interne consistentie betreft van voldoende samenhang zijn. ${ }^{29}$

Om de effecten van geslacht op het bereikte competentieniveau te analyseren, waarbij ook gekeken wordt of dit verschilt tussen leeromgevingen, is wederom een aantal multivariate analyses uitgevoerd. In alle analyses is, waar van toepassing, gecontroleerd voor dezelfde achtergrondkenmerken als in de analyses met betrekking tot het afstudeercijfer. In eerste instantie is geanalyseerd of er verschillen zijn in het type en niveau van competenties afhankelijk van de nadruk die gelegd wordt op de docent als centrale bron van informatie (docentgericht versus studentgericht) en de nadruk die gelegd wordt op project-/probleemgestuurd onderwijs (zie Tabel 5.3).

TABEL 5.3 OLS analyses op competenties (coëfficiënten van a) docentgericht en b) project-/ probleemgestuurd): WO en HBO

\begin{tabular}{|l|c|c|c|} 
& Vakkennis & $\begin{array}{c}\text { Coördinerend en samenwerkend } \\
\text { vermogen }\end{array}$ & \begin{tabular}{c} 
Academische vaardigheden \\
\hline Docentgericht $(1=\mathrm{ja})$
\end{tabular}$\quad 0.057$ \\
\hline Project-/probleemgestuurd $(1=\mathrm{ja})$ & 0.030 & 0.032 & 0.021 \\
\hline
\end{tabular}

Bron: REFLEX; ${ }^{* * *} / * * *$ significant van nul verschillend op $10 \% / 5 \% / 1 \%$ niveau

De eerste set van analyses laat zien dat:

- afgestudeerden van leeromgevingen waarin project-/probleemgestuurd onderwijs benadrukt wordt, een hoger niveau aan 'coördinerend en samenwerkend vermogen' en aan 'academische vaardigheden' hebben dan de afgestudeerden van leeromgevingen waarin geen nadruk wordt gelegd op project-/probleemgestuurd onderwijs.

- de nadruk op project-/probleemgestuurd onderwijs niet ten koste gaat van het niveau aan vakkennis.

Deze resultaten zijn gedeeltelijk in lijn met hetgeen eerder gevonden is door Meng (2006) op basis van een oudere dataset, de CHEERS data, die eveneens betrekking had op afgestudeerden van het hoger onderwijs in een twaalftal Europese landen. Meng (2006) vond eveneens dat project-/probleemgestuurd onderwijs een positief effect op academische vaardigheden had. ${ }^{30}$ Echter hij vond ook een positief effect van docentge-

29 Cronbach alpha $>0,7$. Nadere analyses laten daarbij zien dat het weglaten van een of meerdere items de interne samenhang niet verbetert.

30 Coördinerend en samenwerkend vermogen werd door Meng (2006) niet apart onderzocht. 
richt onderwijs op vakkennis. Dit resultaat vinden we op basis van de REFLEX data niet, althans niet voor Nederland.

In tweede instantie is gekeken of de competentieniveaus verschillen tussen jongens en meisjes. Aangezien er op dit punt geen duidelijke verschillen te zien waren tussen afgestudeerden van het HBO en afgestudeerden van het WO, presenteren we in Tabel 5.4 de kernresultaten (coëfficiënt voor dummy 'vrouw') van de analyses voor de gehele populatie.

TABEL 5.4 OLS regressie op competenties: coëfficiënt voor vrouwen

\begin{tabular}{|l|c|c|c|c|c|}
\hline & Alle leeromgevingen & $\begin{array}{r}\text { Leeromgeving } \\
(1)\end{array}$ & $\begin{array}{r}\text { Leeromgeving } \\
(2)\end{array}$ & $\begin{array}{r}\text { Leeromgeving } \\
\text { (3) }\end{array}$ & $\begin{array}{r}\text { Leeromgeving } \\
\text { (4) }\end{array}$ \\
\hline Vakkennis & $-0.093^{* *}$ & -0.084 & -0.081 & -0.133 & -0.083 \\
\hline $\begin{array}{l}\text { Coördinerend en } \\
\text { samenwerkend vermogen }\end{array}$ & 0.018 & -0.091 & -0.047 & 0.030 & 0.050 \\
\hline Academische vaardigheden & $-0.124^{* * *}$ & -0.096 & $-0.150^{* *}$ & $-0.172^{* * *}$ & $-0.105^{* *}$ \\
\hline
\end{tabular}

Bron: REFLEX; ******* significant van nul verschillend op $10 \% / 5 \% / 1 \%$ niveau

De uitkomsten van deze analyses zijn nogal verrassend. Terwijl we eerder vonden dat het gemiddeld afstudeercijfer in 2 van de 4 onderscheiden leeromgevingen bij meisjes hoger ligt dan bij jongens ${ }^{31}$, vinden we dat het niveau van competenties of niet verschilt tussen jongens en meisjes, of in het geval van academische vaardigheden, in 3 van de 4 onderscheiden leeromgevingen voor meisjes lager uitvalt. Met andere woorden, het hogere afstudeercijfer vertaalt zich niet in hogere niveaus van competenties.

Nu zou het kunnen zijn dat dit verschil komt omdat jongens hun eigen competenties eerder overschatten, terwijl meisjes hun competenties juist onderschatten. Uit de literatuur zijn hier ook wel aanwijzingen voor (Humburg en van der Velden, 2015). Bovendien laten Humburg en van der Velden (2015) zien dat de over- of onderschattingen van competenties sterk varieert per land. Om voor een eventuele structurele verschil in overschatting te controleren is op basis van een additionele vraag in het databestand ("hoe zou u uw afstudeercijfer inschatten in vergelijking met andere afgestudeerden van uw opleiding"; antwoordmogelijkheden: 1. "veel lager dan gemiddeld", 2. "lager dan gemiddeld", 3. "gemiddeld", 4. "hoger dan gemiddeld", 5. "veel hoger dan gemiddeld" en een

31 Dit resultaat werd vooral veroorzaakt door een sterke invloed in het $\mathrm{HBO}$, terwijl in het WO geen significante verschillen gevonden konden worden. 
restcategorie 6. "weet niet") in combinatie met het 'echte' gemiddelde afstudeercijfer op individueel niveau een indicator gemaakt van de mate van overschatting. ${ }^{32}$

Een aparte analyse van het effect van geslacht op de mate van overschatting laat zien dat jongens inderdaad vaker hun examenresultaten overschatten. ${ }^{33}$

Tabel 5.5 presenteert wederom de coëfficiënt voor 'vrouwen' nu met een controle voor overschatting en "weet niet".

TABEL 5.5 OLS regressie op competenties: coëfficiënt voor vrouwen (met controle voor overschatting)

\begin{tabular}{|l|c|r|r|r|r|} 
& Alle leeromgevingen & $\begin{array}{r}\text { Leeromgeving } \\
(1)\end{array}$ & $\begin{array}{r}\text { Leeromgeving } \\
(2)\end{array}$ & $\begin{array}{r}\text { Leeromgeving } \\
\text { (3) }\end{array}$ & $\begin{array}{r}\text { Leeromgeving } \\
(4)\end{array}$ \\
\hline Vakkennis & $-0.094^{* *}$ & -0.077 & -0.099 & -0.131 & -0.076 \\
\hline $\begin{array}{l}\text { Coördinerend en samenwerkend } \\
\text { vermogen }\end{array}$ & 0.020 & -0.076 & -0.048 & 0.034 & 0.048 \\
\hline Academische vaardigheden & $-0.120^{* * *}$ & -0.094 & $-0.154^{* *}$ & $-0.152^{* * *}$ & $-0.103^{* *}$ \\
\hline
\end{tabular}

Bron: REFLEX; ******* significant van nul verschillend op $10 \% / 5 \% / 1 \%$ niveau

Het meest opvallend is dat de coëfficiënten nauwelijks verschillen van die uit de vorige analyse. Dat betekent dat ook na controle voor overschatting, meisjes lager scoren op academische vaardigheden in drie van de vier leeromgevingen.

Dit betekent dat we een gemengd beeld krijgen uit de analyses. Enerzijds bevestigen de analyses het hogere studiesucces van meisjes: meisjes halen hoger examencijfers dan jongens en dat blijkt met name het geval in leeromgevingen waar de student een meer actieve rol heeft en van hen meer zelfstandigheid wordt verwacht. Aan de andere kant vertalen deze hogere examencijfers zich niet een hoger niveau van competenties, terwijl men dat wel zou verwachten.

Er zijn drie mogelijke oorzaken voor deze anomalie in de bevindingen. Op de eerste plaats moeten we bedenken dat het hier gaat om zelfoordelen over de competenties. Daarin schuilt altijd een subjectief element waardoor sprake kan zijn van overschatting of juist onderschatting. In de analyse laten we zien dat dit echter nauwelijks een rol

32 Hiertoe is eerst de variabele "gemiddeld examencijfer" gestandaardiseerd tot een variabele met gemiddelde o en standaarddeviatie 1. De variabele "inschatting in vergelijking met de rest" is als volgt herzien. Eerst is het gemiddelde en de standaarddeviatie bepaald voor de degenen die een waarde 1-5 hebben ingevuld. Dit gemiddelde is 3,38 en de standaarddeviatie is 0,665 . Vervolgens is de waarde "weet niet" gehercodeerd tot het gemiddelde (3,38). Daarna is de variabele als volgt "gestandaardiseerd": Nieuwe variabele = (oude variabele - 3)/0.665. Dit lijkt op standaardiseren, met dit verschil dat een positieve uitkomst altijd duidt op absolute overschatting en een negatieve uitkomst op absolute onderschatting. Dit komt omdat niet het gemiddelde is afgetrokken $(3,38)$, maar de waarde 3 die immers staat voor gemiddeld. De individuele overschatting kan nu berekend worden als de verschilscore tussen beide variabelen. Daarnaast is ook een dummy aangemaakt voor de categorie "weet niet" om het effect daarvan te bepalen.

33 Het effect van de dummy vrouw is, na controle voor de achtergrondkenmerken, -0,129 (significant verschillend van nul op $1 \%$ niveau)***. Er is daarbij geen significant verschil tussen jongens en meisjes in de mate waarin men de categorie "weet niet" invult. 
speelt. Ook na controle voor een indicator overschatting, is nog steeds sprake van lagere academische competenties voor meisjes. Als deze correctiefactor echter niet voldoende is, kan er nog steeds sprake zijn van een onderschatting van de competenties door meisjes.

Een tweede oorzaak kan liggen in het feit dat de competenties gemeten zijn vijf jaar na het verlaten van de opleiding. Misschien dat jongens na het verlaten van de opleiding een inhaalslag maken doordat ze in betere banen terechtkomen die meer mogelijkheden bieden om de competenties verder te ontwikkelen.

En ten slotte kan het zijn dat de relatie tussen examencijfers en bereikt niveau van competenties helemaal niet zo sterk is. Het kan zijn dat examencijfers meer bepaald worden door inzet en motivatie en minder door een verschil in competenties. Eerder onderzoek van Büchner et al. (2012) laat zien dat meisjes een hoger onderwijsniveau behalen dan op grond van de scores op de CITO-test op 12-jarige leeftijd verwacht mag worden. Bij jongens daarentegen zijn de CITO-scores veel meer bepalend voor het te bereiken onderwijsniveau. Dit wijst op een sterkere rol van bijvoorbeeld motivationele aspecten bij het verklaren van het studiesucces van meisjes. Interessant is dat op de arbeidsmarkt de oorspronkelijke CITO-scores bij meisjes wel weer een effect hebben op hun beloning (apart van het indirecte effect via het bereikte onderwijsniveau en -richting), terwijl dat bij jongens niet het geval is. Met andere woorden: bij jongens verloopt het effect van cognitieve vaardigheden op 12-jarige leeftijd op de latere beloning helemaal via de onderwijsloopbaan. Ook dit suggereert dat het hogere studiesucces van meisjes niet automatisch vertaald hoeft te worden in een hoger niveau van competenties.

Een eventueel belangrijke tekortkoming van de analyses in dit hoofdstuk is het gegeven dat het aan een harde meting van competenties ontbreekt in de hiervoor beschikbare data. In hoofdstuk 6 komen we hierop terug, wanneer we gaan kijken naar de verschillen tussen jongens en meisjes in objectieve testscores.

\section{KERNCONCLUSIES}

- Meisjes doen het in het HBO vooral beter in situaties waarin van de student een actieve rol verwacht wordt en de docent geen centrale rol als bron van informatie is.

- Het hoger afstudeercijfer van meisjes in het HO vertaalt zich niet in hogere niveaus van competenties. 


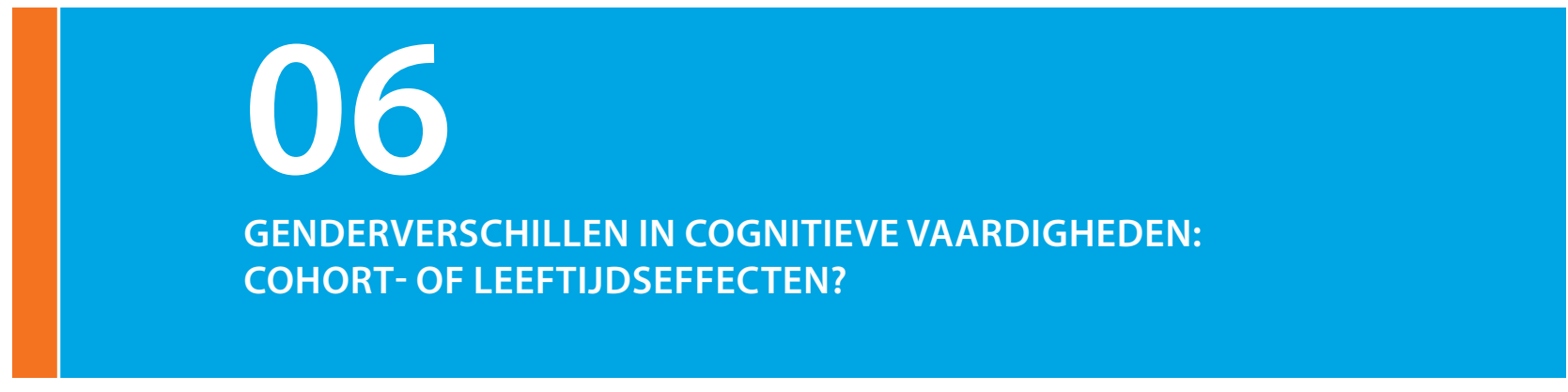

\section{Barbara Belfi, Mark Levels en Rolf van der Velden (Researchcentrum voor Onderwijs en Arbeidsmarkt)}

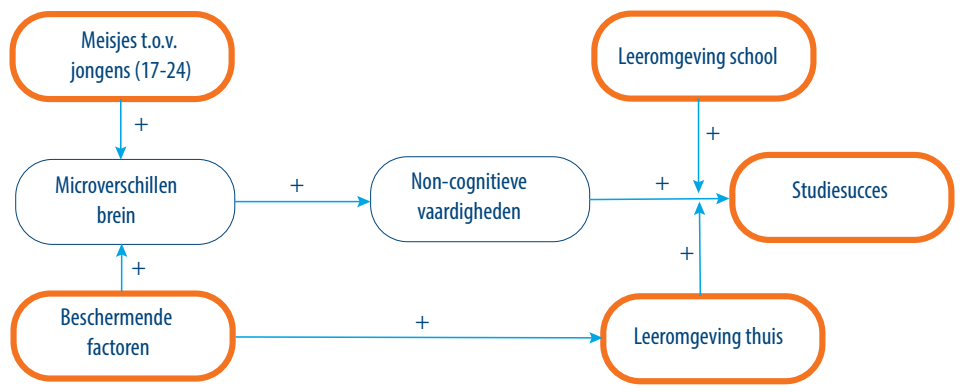

\section{Samenvatting}

In de vorige hoofdstukken hebben we ons vooral gefocust op het verschil in studiesucces tussen jongens en meisjes ten tijde van de studie zelf. In het huidige hoofdstuk verrichtten we aan de hand van OECD-data een empirisch onderzoek naar mogelijke genderverschillen in cognitieve vaardigheden op langere termijn (18-34 jaar). Hierbij wordt tevens nagegaan in welke mate eventuele gender gaps in cognitieve prestaties verschillen tussen jongvolwassenen uit verschillende geboortecohorten. Een aanleiding voor de verwachting dat er sprake zou kunnen zijn van cohortverschillen in cognitieve vaardigheden is gelegen in de aanname dat mensen uit andere geboortecohorten onder andere omstandigheden onderwijs hebben genoten. We bestuderen daarom veranderingen in genderverschillen in taal- en rekenvaardigheden tussen mensen uit verschillende geboortecohorten, en gaan na of er op dit punt verschillen zijn tussen personen met een laag, gemiddeld of hoog opleidingsniveau. Indien onderwijshervormingen een effect hebben op de gender gap in cognitieve vaardigheden, dan verwachten we dat de gevolgen van deze hervormingen zich vooral als cohorteffecten manifesteren. Uit de analyses blijkt dat voor middelbaar en hoogopgeleide mannen en vrouwen de verwachte cohorteffecten niet zijn waar te nemen. Middelbaar- en hoogopgeleide mannen beschikken over een even goede taalvaardigheid als, en een iets betere rekenvaardigheid dan vergelijkbare vrouwen. Alleen onder de laagst opgeleide jongvolwassenen observeren wij genderverschillen in cognitieve vaardigheden in verschillende 
cohorten. Dit is zowel voor taal- als rekenvaardigheid het geval. Dat komt vooral doordat laag opgeleide vrouwen uit jongere cohorten het veel beter doen dan laagopgeleide vrouwen uit oudere cohorten, terwijl mannen geen of slechts een geringe stijging laten zien.

\subsection{Inleiding}

In de afgelopen jaren is steeds meer aandacht gekomen voor de achterblijvende prestaties van jongens in het onderwijs. Jongens blijven vaker zitten, worden vaker doorverwezen naar het speciaal onderwijs en zijn vaker voortijdig schoolverlaters dan meisjes. Tegelijkertijd is duidelijk geworden dat er sprake is van lagere prestaties van meisjes in de traditioneel mannelijke vakken zoals wiskunde, wetenschappen en techniek (Driessen en Van Langen, 2011; Schaacke, 2014). Tot dusverre heeft onderzoek naar sekseverschillen in het onderwijs zich vooral gericht op prestatieverschillen tussen jongens en meisjes het primair en voortgezet onderwijs. Er is vooralsnog weinig bekend over hoe de prestaties van (jong)volwassen mannen zich verhouden tot die van hun vrouwelijke leeftijdsgenoten. Het huidige onderzoek heeft tot doel hier meer inzicht te verkrijgen.

Uit de Nederlandse resultaten van het PISA ${ }^{34}$-onderzoek blijkt dat in de laatste vier PISAmetingen die in de afgelopen twaalf jaar zijn uitgevoerd, vijftienjarige jongens beter presteren op het gebied van rekenvaardigheid en meisjes beter scoren op het gebied van taalvaardigheid. In Tabel 6.1 is te zien dat terwijl de voorsprong van meisjes in taal in de afgelopen jaren is toegenomen, de voorsprong van jongens in rekenen een minder duidelijk patroon aanneemt. Bovendien is opvallend dat gemiddeld over alle metingen, de voorsprong van meisjes in taal bijna twee keer zo groot is als de voorsprong van jongens in rekenen.

TABEL 6.1 Ontwikkelingen in genderverschillen in taal- en rekenvaardigheid in Nederland op basis van vier PISA-metingen

\begin{tabular}{|l|c|c|}
\hline PISA & $\begin{array}{c}\text { Taalvaardigheid } \\
\text { Jongens-Meisjes verschil }\end{array}$ & $\begin{array}{c}\text { Rekenvaardigheid } \\
\text { Jongens-Meisjes verschil }\end{array}$ \\
\hline 2003 & -21 & 5 \\
\hline 2006 & -24 & 13 \\
\hline 2009 & -25 & 17 \\
\hline 2012 & -27 & 10 \\
\hline
\end{tabular}

Een groeiende groep wetenschappers stelt dat de toenemende voorsprong van meisjes op jongens voor wat betreft taal gelegen is in 'vrouwvriendelijke' veranderingen die in de afgelopen decennia in de leeromgeving van het primair- en voortgezet onderwijs zijn doorgevoerd (Claessen, 2013; Luken, 2008). Zo wordt tegenwoordig in het onderwijs

34 PISA (Programme for International Student Assessment) is een grootschalig internationaal vergelijkend onderzoek naar de cognitieve vaardigheden van 15-jarigen, dat wordt uitgevoerd onder auspiciën van de Organisatie voor Economische Samenwerking en Ontwikkeling (OESO). 
steeds meer aandacht aan taal besteed. Communicatieve vaardigheden als het schrijven van werkstukken en het geven van presentaties spelen een steeds grotere rol in het primair en voortgezet onderwijs. Vooral meisjes zouden hier voordeel van hebben, omdat zij van nature meer gebruik zouden maken van verbaal-linguïstische leerstrategieën dan jongens (Claessen, 2013; Luken, 2008). Op hun beurt zouden jongens weer meer gebruik maken van visueel-ruimtelijke leerstrategieën, die vooral van pas komen bij het oplossen van rekenkundige problemen. Maar ook het reken- en wiskundeonderwijs op de middelbare school is de afgelopen jaren 'taliger' geworden.

Naast taalvaardigheid is ook sociale interactie de afgelopen decennia steeds belangrijker geworden binnen het onderwijs. Sociale activiteiten als 'samen een werkstuk maken', waarvoor overleg en afstemming nodig is, staat steeds meer centraal in het huidige primair en voortgezet onderwijs. Ook van deze verandering zouden meisjes meer profijt hebben dan jongens. Onderzoek van Jolles en collega's heeft bijvoorbeeld aangetoond dat meisjes vaardiger zijn dan jongens in de non-cognitieve functies die voor sociale interacties van belang zijn, zoals zelfinzicht, zelfregulatie, impulsbeheersing, plannen, prioritering en empathie (Jolles, 2007; Veroude et al., 2013; Woelders et al., 2014). Onderzoek van het ROA laat verder zien dat de nadruk die op sociale interacties is komen te liggen in het voortgezet onderwijs na de invoering van het Studiehuis in het havo en vwo inderdaad voordeliger is geweest voor de prestaties van meisjes dan voor die van jongens (Coenen, Meng en Van der Velden, 2011). Dit wordt door de onderzoekers toegeschreven aan het feit dat meisjes meer capabel zijn dan jongens in vaardigheden die kenmerkend zijn voor deze vorm van onderwijs, zoals zelfstandig werken, samenwerken, het maken van een realistische studieplanning en informatie verzamelen en verwerken.

Een belangrijke vraag is of jongens en meisjes hun aanvankelijke achterstand ten opzichte van elkaar (in taal c.q. wiskunde) weten weg te werken in het postsecundair en tertiair onderwijs of dat deze juist versterkt worden. In de afgelopen decennia zijn immers ook in het middelbaar en hoger onderwijs onderwijshervormingen doorgevoerd die eerder in het voordeel van vrouwen dan van mannen zouden kunnen werken. Het competentiegericht onderwijs in het mbo en hbo en projectgericht/probleemgestuurd onderwijs in het wo zijn onderwijsvormen waarbij onderwijsactiviteiten als zelfstandig leren en samenwerken in groepen centraler zijn komen te staan. Het is goed mogelijk dat door deze 'vrouwvriendelijke' onderwijshervormingen in het middelbaar en hoger onderwijs, de eerder gesignaleerde voorsprong van meisjes op het gebied van taal verder heeft doen toenemen.

Om deze kwesties goed te bestuderen, moeten taal- en rekenvaardigheden van jongens en meisjes op jongvolwassen leeftijd worden vergeleken. Buisman en collega's (2013) stelden op basis van de PIAAC-data ${ }^{35}$ vast dat jongvolwassen mannen in de leeftijd van

35 PIAAC (Programme for International Assessment of Adult Comeptencies) is een grootschalig internationaal vergelijkend onderzoek naar de cognitieve vaardigheden van 16-64-jarigen, dat wordt uitgevoerd onder auspiciën van de Organisatie voor Economische Samenwerking en Ontwikkeling (OESO). 
$16 \mathrm{t} / \mathrm{m} 34$ jaar hoger scoren dan hun vrouwelijke leeftijdsgenoten op zowel wiskunde als taal. Met name het laatste resultaat zou suggereren dat meisjes hun aanvankelijke voorsprong op het gebied van taal weer kwijtraken. ${ }^{36}$ Probleem is echter dat het hier gaat om de totale groep 16-34-jarigen, waardoor er ook sprake kan zijn van cohorteffecten: de mannen uit de eerdere geboortecohorten (34-jarigen) doen het wellicht beter dan de mannen uit de latere geboortecohorten (16-jarigen). Om hier meer zicht op te krijgen analyseren we in dit hoofdstuk nogmaals deze PIAAC-data, maar nu afzonderlijk voor mannen en vrouwen uit verschillende geboortecohorten. Om uitsluitsel te krijgen over dat gevonden effecten geïnterpreteerd moeten worden als leeftijd- of cohorteffecten vergelijken we de resultaten van PIAAC met die van eerdere adult literacy surveys IALS (International Adult Literacy Survey) en ALL (Adult Literacy and Life Skills Survey).

\subsection{Onderzoeksdoel en -vragen}

Dit hoofdstuk heeft als doel meer inzicht te krijgen in vaardigheidsverschillen tussen jongvolwassen jongens en meisjes in het middelbaar en hoger onderwijs. We bestuderen veranderingen in genderverschillen in cognitieve vaardigheden tussen mensen uit verschillende geboortecohorten, en gaan na of er op dit punt verschillen zijn tussen personen met een laag, gemiddeld of hoog opleidingsniveau. Indien onderwijshervormingen een effect hebben op de gender gap in cognitieve vaardigheden, dan verwachten we dat de gevolgen van deze hervormingen zich vooral als cohorteffecten manifesteren.

We zoeken in dit hoofdstuk naar verklaringen voor geobserveerde trends en onderzoeken hoe aannemelijk het is dat trends kunnen worden geïnterpreteerd als leeftijdsof als cohorteffecten. Daartoe analyseren we onder meer gegevens van drie internationale metingen naar cognitieve vaardigheden die in afgelopen twee decennia onder Nederlandse jongvolwassen mannen en vrouwen hebben plaatsgevonden (namelijk, IALS, ALL en PIAAC). We heranalyseren bovendien gegevens van het PISA-onderzoek voor Nederlandse jongens en meisjes met een laag (praktijkonderwijs/vmbo) of hoog opleidingsniveau (havo/vwo), om na te gaan of trends hierin hetzelfde zijn als in IALS, ALL en PIAAC.

De analyses geven antwoord op de volgende onderzoeksvragen:

- (1) In welke mate is er sprake van genderverschillen in de cognitieve vaardigheden van jongvolwassen (18-34) mannen en vrouwen met verschillende opleidingsniveaus?

36 Ook Amerikaans onderzoek lijkt in deze richting te wijzen. Jongvolwassen mannen scoren hoger dan vrouwen op gestandaardiseerde testen, zoals de American College Testing (ACT) en de Scholastic Aptitude Test (SAT), die jongvolwassen dienen te behalen om te worden toegelaten tot het hoger onderwijs (Duckworth \& Seligman, 2006). 
- (2) In welke mate verschillen genderverschillen in cognitieve vaardigheden tussen jongvolwassenen uit verschillende geboortecohorten?

- (3) In hoeverre zijn (mogelijke) genderverschillen in verschillende cohorten te verklaren door variabelen die sterk met cognitieve vaardigheden samenhangen zoals sociaaleconomische achtergrond, etniciteit, werkervaring, arbeidsparticipatie, de toepassing van cognitieve vaardigheden thuis en studiekeuze?

- (4) In hoeverre is het aannemelijk dat geobserveerde genderverschillen kunnen worden toegeschreven aan cohorteffecten (zoals het invoeren van vrouwvriendelijke leeromgevingen)?

\subsection{Data en methoden}

Aan de hand van de data van vier grote internationale onderzoeken naar het cognitieve vaardigheidsniveau van jongvolwassen Nederlandse mannen en vrouwen van de OESO (Organisatie voor Economische Samenwerking en Ontwikkeling) gaan we na of het cognitieve vaardigheidsniveau van jongvolwassen Nederlandse mannen en vrouwen met verschillende opleidingsniveaus, in de laatste jaren al dan niet is veranderd. We verrichten de volgende vier analyses:

Allereerst onderzoeken we aan de hand van Nederlandse PIAAC-data uit 2013, of er verschillen zijn in de cognitieve vaardigheden van Nederlandse jongvolwassen mannen en vrouwen die tussen 1979 en 1995 zijn geboren, uitgesplitst naar opleidingsniveau en geboortecohort. Deze personen waren bij afname van de PIAAC-test tussen de 18 en 34 jaar oud. We delen de jongvolwassenen in drie opleidingsniveaus in: laag-, middelbaar en hoogopgeleiden. Met laagopgeleiden $(\mathrm{N}=310)$ worden mensen bedoeld die geen opleiding, alleen basisonderwijs, of ten hoogste een VMBO-diploma hebben (ISCED $1 \mathrm{t} / \mathrm{m}$ 4). Middelbaar opgeleiden ( $\mathrm{N}=730$ ) zijn mensen die ten hoogste een HAVO, VWO, MBO-diploma of een zogeheten tertiair professioneel (ISCED 5) diploma hebben behaald. Hoogopgeleiden $(\mathrm{N}=407)$ zijn mensen die het $\mathrm{HBO}$ of WO hebben afgerond (ISCED 6 en hoger). We bezien of en in hoeverre de cognitieve vaardigheden van jongvolwassen jongens en meisjes met verschillende opleidingsniveaus verschillen over de tijd, en toetsen een aantal veelgehoorde verklaringen voor die verschillen.

Indien leeromgevingen bijdragen aan de verklaring van genderverschillen, dan verwachten we cohorteffecten waar te nemen, waarbij de kloof in bijvoorbeeld taalvaardigheid groter is voor cohorten die meer recent onderwijs hebben genoten. Op basis van alleen de PIAAC data set is echter niet vast te stellen of geobserveerde trends moeten worden geïnterpreteerd als leeftijds- of cohorteffecten. Om meer grip op die vragen te krijgen, analyseren we aanvullende data sets. Zo bestuderen we IALS en ALL data van de OESO die een soortgelijke dataverzameling als PIAAC betreffen: beiden meten ze ook de cognitieve vaardigheden van volwassenen. IALS vond plaats in 1996 en ALL in 2006. Personen die tijdens testafnames van IALS en ALL tussen de 18 en 34 oud waren, zijn dus afkomstig uit andere geboortecohorten dan de personen die tussen de 
18 en 34 jaar oud waren bij afname van de PIAAC-test. Hierdoor kunnen we nagaan of er bij personen die tot eenzelfde leeftijdsgroep maar een ander geboortecohort behoren, sprake is van vergelijkbare trends in cognitieve vaardigheidsniveaus.

Voor de cognitieve vaardigheidstoetsen die de OESO driejaarlijks houdt in het kader van PISA wordt een steekproef gebruikt van kinderen van 15 jaar oud. Doordat de PISAgegevens constant zijn wat betreft leeftijd, kunnen we cohorteffecten isoleren. We onderzoeken aan de hand van de PISA-data uit 2003, 2006 en 2009 of we genderverschillen tussen verschillende geboortecohorten waarnemen wanneer we jongens en meisjes naar opleidingsniveau indelen. Vervolgens vergelijken we deze patronen met de patronen die we in de eerdere analyses vonden.

\subsection{Resultaten}

\subsubsection{Genderverschillen in cognitieve vaardigheden van Nederlandse jongvolwassenen met verschillende opleidingsniveaus}

We beginnen onze studie met het analyseren van de recente PIAAC-gegevens, zoals in 2013 verzameld door de OESO. Figuur 6.1 toont geobserveerde genderverschillen van Nederlandse jongvolwassenen in reken- en taalvaardigheid. Zowel bij de hoog-, middelbaar en laagopgeleiden, vertonen mannen een significant betere rekenvaardigheid dan vrouwen. Deze voorsprong van mannen ten opzichte van vrouwen is het grootst bij de hoogopgeleiden en het kleinst bij de laagopgeleiden. Opvallend is dat ook op het gebied van taalvaardigheid hoogopgeleide jongvolwassen mannen het significant beter doen dan hun vrouwelijke evenknieën. Bij de middelbaar- en laagopgeleiden zijn er geen significante verschillen tussen de taalvaardigheid van jongvolwassen mannen en vrouwen. De geobserveerde verschillen zijn sterk vergelijkbaar met eerdere analyses van de PIAAC data (Buisman et al., 2013). ${ }^{37}$

37 De resultaten wijken iets af van de resultaten gepresenteerd door Buisman et al. (2013). Dit komt door de minder fijne indeling van opleidingsniveaus. 
FIGUUR 6.1 Genderverschillen in PIAAC kernvaardigheden van Nederlandse jongvolwassenen (17-34), naar gelang opleidingsniveau

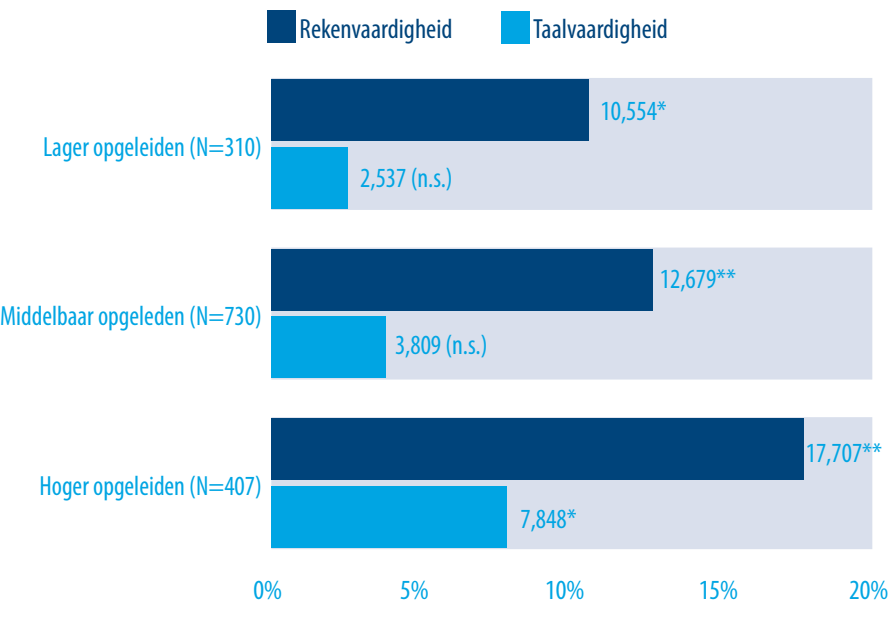

\subsubsection{Genderverschillen in cognitieve vaardigheden van Nederlandse jongvolwassenen uit verschillende geboortecohorten, naar opleidingsniveau (op basis van PIAAC-data)}

In Figuur 6.2 worden de genderverschillen in cognitieve vaardigheden van Nederlandse jongvolwassenen uit verschillende geboortecohorten grafisch weergegeven naar opleidingsniveau. We vergelijken hier de cognitieve prestaties van jongvolwassen mannen en vrouwen uit verschillende geboortejaren. De effecten zijn gecontroleerd voor ouderlijke sociaaleconomische achtergrond, immigrantenstatus, werkervaring, het al dan niet nog op school zitten en arbeidsparticipatie.

Figuur 6.2.1a toont allereerst de ontwikkelingen in genderverschillen in taalvaardigheid tussen jongere en oudere cohorten, waarbij geen onderscheid is gemaakt naar opleidingsniveau. Te zien is dat mannen uit de oudere cohorten taalvaardiger zijn dan mannen uit de jongere cohorten. Dat geldt ook voor vrouwen. De verschillen tussen mannen en vrouwen zijn klein, maar jonge mannen zijn er in vergelijking met mannen uit oudere cohorten meer op achteruit gegaan dan vrouwen. Figuur 6.2.1 b toont de ontwikkelingen in genderverschillen in rekenvaardigheid tussen jongere en oudere cohorten. Ook hier is nog geen onderscheid gemaakt tussen mensen met verschillende opleidingsniveaus. Ontwikkelingen in rekenvaardigheid zijn vergelijkbaar met ontwikkelingen in taalvaardigheid: oudere mannen kunnen beter rekenen dan jongere mannen, en vrouwen uit oudere cohorten beter dan vrouwen uit jongere cohorten. Mannen doen het gemiddeld genomen even goed als vrouwen. 
FIGUUR 6.2 Genderverschillen in PIAAC kernvaardigheden van Nederlandse jongvolwassenen uit verschillende geboortecohorten, naar opleidingsniveau

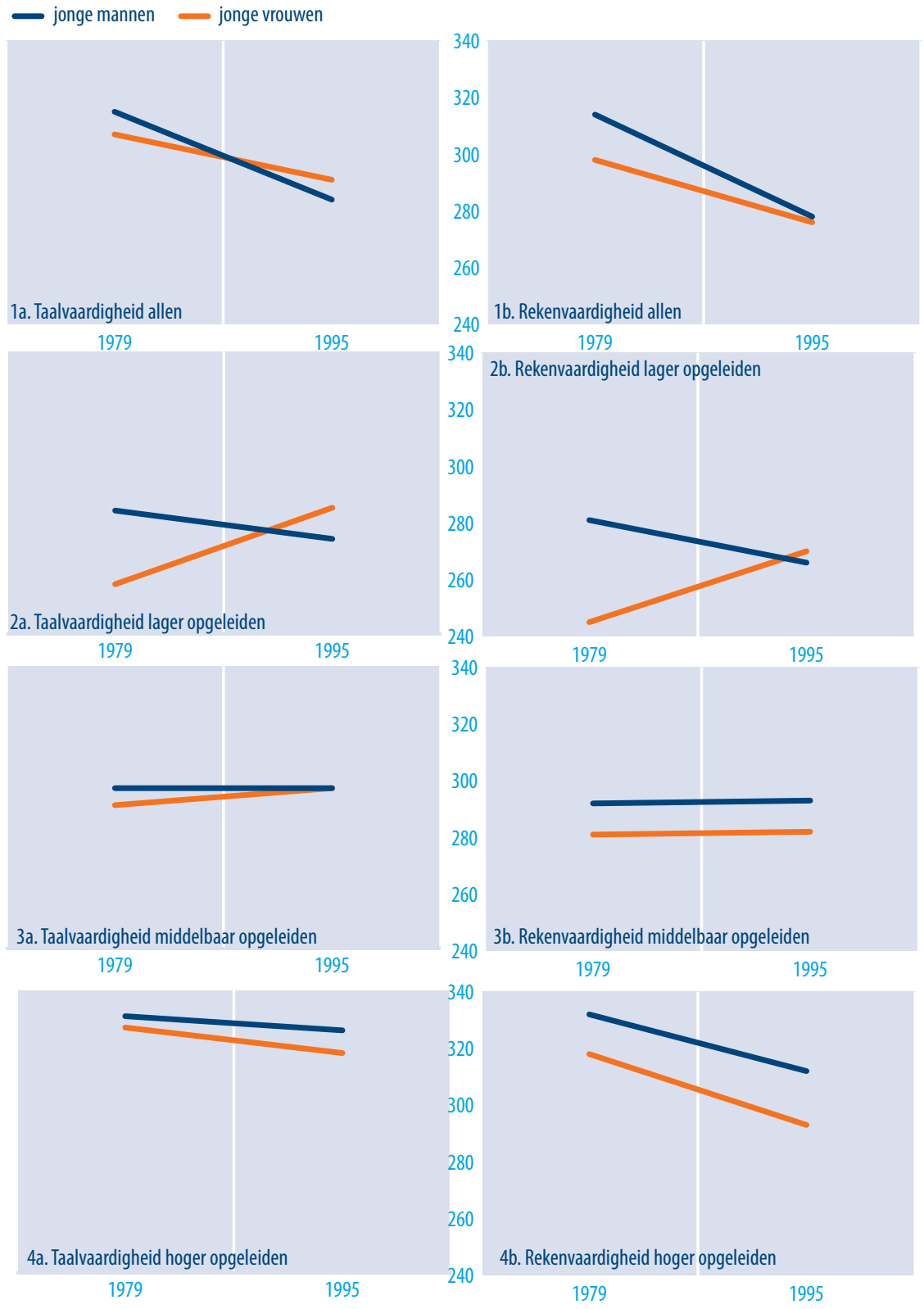


In Figuren 6.2.2a-6.2.4b worden ontwikkelingen in genderverschillen in cognitieve vaardigheden uitgesplitst naar cohort en opleidingsniveau. In Figuur 6.2.2a is te zien dat zich bij lager opgeleiden mensen tussen de geboortecohorten van 1979 tot en met 1995 een belangrijke ontwikkeling heeft voorgedaan in het genderverschil in taalvaardigheid van laagopgeleide jongvolwassenen. Laagopgeleide vrouwen uit jonge cohorten zijn veel taalvaardiger dan laagopgeleide vrouwen uit oudere cohorten. De taalvaardigheid van laagopgeleide mannen is over de cohorten daarentegen wat afgenomen. Een soortgelijk patroon is zichtbaar in Figuur 6.2.2b, die de ontwikkeling in genderverschillen in rekenvaardigheid tussen jongere en oudere cohorten toont.

Figuur 6.2.3a en 6.2.3b laten zien dat het plaatje er voor middelbaar opgeleiden iets anders uitziet. In Figuur 6.2.3a is te zien dat de taalvaardigheid van zowel middelbaar opgeleide mannen als vrouwen uit jongere cohorten ongeveer even goed is als die van hun evenknieën uit oudere cohorten. De in onze data gevonden lineaire interactie is erg klein, en bovendien niet significant. Hoewel middelbaar opgeleide mannen gemiddeld genomen beter kunnen rekenen dan even hoog opgeleide vrouwen, zijn ze even taalvaardig.

In Figuur 6.2.4a en 6.2.4b wordt de ontwikkeling van cognitieve vaardigheden van hoogopgeleide jongvolwassenen uit verschillende geboortecohorten weergegeven. In Figuur 6.2.4a is te zien dat hoogopgeleide jongvolwassen mannen en vrouwen in alle cohorten hetzelfde presteren op het gebied van taalvaardigheid. Hoger opgeleide mannen en vrouwen van verschillende cohorten doen het dus even goed op de PIAAC taaltoetsen. Van een ontwikkeling in de tijd is geen sprake. Figuur 6.2.4b laat een iets ander beeld zien voor wat betreft ontwikkelingen in de rekenvaardigheid van hoger opgeleide jongvolwassenen. Hoogopgeleide mannen vertonen in zowel de oudere als in de jongere cohorten een betere rekenvaardigheid dan hun vrouwelijke equivalenten. Voor mannen zien wij echter geen significante verschillen tussen cohorten. Het effect is relatief groot, maar niet statistisch significant. Jongere hoogopgeleide vrouwen kunnen daarentegen iets minder goed rekenen dan hoogopgeleide vrouwen uit eerdere geboortecohorten.

Samenvattend biedt Figuur 6.2 ruimte voor drie voorzichtige conclusies. Ten eerste lijken genderverschillen in de ontwikkeling van cognitieve vaardigheden van Nederlandse jongvolwassenen vooral te worden gedreven door verschillen bij laagopgeleide jongvolwassenen. Jongere laagopgeleide mannen zijn iets minder taal- en rekenvaardig dan laagopgeleide mannen, maar jongere laagopgeleide vrouwen zijn op deze gebieden juist vaardiger dan oudere laagopgeleide vrouwen. Ten tweede zijn hoger opgeleide jonge vrouwen iets minder rekenvaardig dan hoger opgeleide oudere jongvolwassen vrouwen. Ten slotte is het nuttig om te concluderen dat er voor middelbaar opgeleiden geen enkele lineaire trend zichtbaar is. 


\subsubsection{Wordt de trend bij laagopgeleide jong volwassenen verklaard door andere variabelen die samenhangen met leeftijdseffecten?}

In deze sectie bezien we of en in hoeverre we de door ons geobserveerde verschillen onder laagopgeleiden kunnen verklaren door rekening te houden met een aantal individuele kenmerken die vaak worden genoemd bij de verklaring van geslachts-, leeftijdsen/of cohortverschillen in cognitieve vaardigheden. Wij presenteren een analyse van verklaringen voor zowel taal- als rekenvaardigheid.

We bezien bijvoorbeeld de mogelijke invloed van de sociaaleconomische status van het ouderlijk milieu. Individuen waarvan de ouders een laag opleidingsniveau -of met andere woorden een lage sociaaleconomische status (SES) hebben- hebben vanuit hun thuissituatie in mindere mate toegang tot educatieve, sociale en psychologische hulpbronnen die hun cognitieve vaardigheden bevorderen, dan individuen met een hoge SES. Personen met een lage SES zijn daardoor in hogere mate gevoelig voor hetgeen wat ze op school krijgen aangeleerd, dan personen met een hoge SES. Wanneer er in de schoolse leeromgeving veranderingen plaatsvinden die gunstig of ongunstig zijn voor (bepaalde typen) leerlingen, dan zal de invloed van deze veranderingen van grotere invloed zijn op lage SES dan op hoge SES leerlingen (Brooks-Gun et al., 1995). Verder heeft onderzoek van Entwisle et al. (2007) aangetoond dat de 'gender gap' in het primair onderwijs groter is voor kinderen uit lage SES-gezinnen dan voor kinderen uit hoge SES-gezinnen. Dit bleek te komen doordat de ouders van dergelijke gezinnen lagere verwachtingen hadden van de schoolprestaties van hun zonen dan van hun dochters. Bovendien bleken lage SES-ouders hun zonen meer stereotype ideeën bij te brengen dan andere ouders, zoals bleek uit de huishoudelijke taken die zonen thuis moesten uitvoeren en uit de beroepsverwachtingen van de ouders voor hun zonen. Ouders in gezinnen met een hoger inkomen hadden niet alleen hogere verwachtingen van hun kinderen, maar maakten ook minder onderscheid tussen jongens en meisjes. Ook kijken we naar de rol van iemands immigrantenstatus. Auduc (2009) stelde vast dat de extreem gender-traditionele opvattingen van sommige allochtone ouders een verklaring biedt voor het relatief grotere schoolsucces van meisjes in vergelijking tot dat van allochtone jongens dat doorgaans door onderzoek wordt aangetoond. Allochtone meisjes zouden onderwijs gebruiken om zich te ontworstelen aan de mannelijke dominantie in hun milieu terwijl deze noodzaak voor hun mannelijke tegenhangers niet aanwezig is. We bezien ook de relevantie van de werkervaring van mensen. Het aantal jaren werkervaring dat iemand heeft is positief gerelateerd aan iemands cognitieve prestaties (Hanushek en Woessman, 2012). Oudere individuen hebben een grotere kans om meer jaren werkervaring te hebben opgedaan dan jongere individuen. Bovendien is er een structurele toename van de arbeidsmarktdeelname van jonge vrouwen. Binnen de door ons onderscheiden opleidingscategorie van lager opgeleiden kijken we ook nog naar verschillen in het aantal jaren onderwijs dat mensen genoten hebben. Er bestaat een algemeen positief verband tussen het aantal jaren onderwijs dat men heeft gevolgd en cognitieve prestaties (Hanushek en Woessman, 2012). Oudere individuen hebben een grotere kans om meer jaren onderwijs te hebben gevolgd dan jongere individuen. Tenslotte bezien we ook de mate waarin mensen thuis lees-, schrijf- en rekenvaardigheden toepassen. 
Naarmate men meer ervaring opdoet in cognitieve vaardigheden (lezen/rekenen), zullen deze vaardigheden verbeteren. Oudere individuen hebben meer kans gehad om deze vaardigheden te oefenen dan jongere individuen.

We voeren de analyse uitsluitend uit voor de laagopgeleide jongvolwassenen omdat voor de middelbaar en hoogopgeleide jongvolwassenen geen trendeffecten gevonden zijn. Tabel 6.3 toont coëfficiënten van het model van de ontwikkelingen in lees- en rekenvaardigheid van de laagopgeleide jongvolwassenen over de verschillende cohorten. Stapsgewijs worden er verschillende kenmerken van individuen en hun ouders aan het model toegevoegd. Model 1a en $2 a$ in Tabel 6.3 zijn de basismodellen. Hierin is nogmaals te zien dat jongvolwassen laagopgeleide mannen in het algemeen lager scoren op taalen rekenvaardigheid dan jongvolwassen laagopgeleide vrouwen, en jongvolwassen laagopgeleide vrouwen uit een ouder geboortecohort lager scoren dan jongvolwassen laagopgeleide vrouwen uit een jonger geboortecohort. Jongvolwassen laagopgeleide mannen uit een ouder geboortecohort scoren daarentegen hoger dan jongvolwassen laagopgeleide mannen uit een jonger geboortecohort. Er is dus sprake van een significant interactie-effect, wat we in Figuur 6.2 ook al zagen. Terwijl laagopgeleide mannen het iets beter doen naarmate ze uit latere cohorten stammen, is de toename onder laagopgeleide vrouwen veel sterker.

In Model $1 \mathrm{~b}$ en $2 \mathrm{~b}$ wordt het opleidingsniveau van de ouders en de immigrantenstatus van de respondenten aan de modellen toegevoegd. Te zien is dat hoe hoger het opleidingsniveau van de ouders is, des te hoger het taal- en rekenvaardigheidsniveau is. Het hebben van een immigrantenstatus hangt negatief samen met zowel het taal- als rekenvaardigheidsniveau van laagopgeleide jongvolwassenen. Zowel het effect van geslacht als het interactie-effect tussen leeftijd en geslacht blijft echter significant. Ouderlijke achtergrond en immigrantenstatus bieden dan ook geen verklaring voor genderverschillen tussen verschillende cohorten. In Model $1 c$ en $2 c$ wordt een aantal verdere individuele kenmerken aan het verklaringsmodel toegevoegd. Van al deze kenmerken bieden enkel nog de werkloosheidsstatus en de mate waarin respondenten thuis leesvaardigheid toepassen additionele verklaring voor het taal- en rekenvaardigheidsniveau van laagopgeleide jongvolwassenen. Werkloosheid hangt negatief met taal- en rekenvaardigheid samen terwijl het toepassen van leesvaardigheid thuis positief met beide cognitieve vaardigheden samenhangt. Werkervaring, het nog op school zitten of de mate waarin thuis schrijf- of rekenvaardigheid wordt toegepast blijkt niet met de taal- en rekenvaardigheid van laagopgeleide jongvolwassenen samen te hangen. Zowel het effect van geslacht als het interactie-effect tussen leeftijd en geslacht blijft significant. Het leeftijdseffect op taalvaardigheid voor vrouwen neemt wel wat af (van -3 naar -2) Voor rekenen wordt het leeftijdseffect voor vrouwen insignificant (en neemt af van -2 naar -1). Dat wijst er op dat een deel van het cohorteffect (laagopgeleide vrouwen doen het in de jongste cohorten beter dan in de oudere cohorten) toegeschreven moet worden aan de werkloosheid of het lees- of rekengedrag van vrouwen in de jongere cohorten. 
TABEL 6.3 Individuele verklaringen voor genderverschillen in PIAAC leesaardigheid onder lager opgeleide Nederlandse jongvolwassenen uit verschillende geboortecohorten

\begin{tabular}{|c|c|c|c|c|c|c|}
\hline Taalvaardigheid & Model 1a & & Model 1b & & Model 1c & \\
\hline Intercept & $283^{* *}$ & & 280 & ** & 229 & ** \\
\hline Mannen (vrouwen =referentie) & -11 & & -13 & $\#$ & -11 & $\#$ \\
\hline Leeftijdseffect vrouwen (jongste cohort = referentie) & -3 & ** & -2 & ** & -2 & * \\
\hline Leeftijdseffect mannen (jongste cohort = referentie) & 2 & * & 2 & $* *$ & 2 & ** \\
\hline Ouders lager opgeleid & & & ref. & & ref. & \\
\hline Ouders middelbaar opgeleid & & & 13 & * & 8 & \\
\hline Ouders hoger opgeleid & & & 19 & $* *$ & 12 & * \\
\hline Immigrant & & & -31 & ** & -26 & ** \\
\hline Hoogste opleidingsniveau (in jaren) & & & & & 2 & \\
\hline Werkervaring (in jaren) & & & & & 0 & \\
\hline Nu op school & & & & & 4 & \\
\hline Nu werkloos & & & & & -16 & $\#$ \\
\hline Index lezen thuis & & & & & 10 & ** \\
\hline Index schrijven thuis & & & & & 3 & \\
\hline Percentage verklaarde variante $\left(100 * R^{2}\right)$ & 5 & & 19 & & 29 & \\
\hline$N$ & 310 & & 310 & & 310 & \\
\hline Rekenvaardigheid & Model 2a & & Model 2b & & Model 2c & \\
\hline Intercept & 266 & ** & 261 & ** & 219 & ** \\
\hline Mannen (vrouwen =referentie) & -4 & & -6 & & -6 & \\
\hline Leeftijdseffect vrouwen (jongste cohort = referentie) & -2 & ** & -2 & ** & -1 & \\
\hline Leeftijdseffect mannen (jongste cohort = referentie) & 2 & * & 3 & ** & 3 & ** \\
\hline Ouders lager opgeleid & & & ref. & & ref. & \\
\hline Ouders middelbaar opgeleid & & & 15 & * & 11 & $\#$ \\
\hline Ouders hoger opgeleid & & & 23 & ** & 16 & * \\
\hline Immigrant & & & -32 & $* *$ & -26 & ** \\
\hline Hoogste opleidingsniveau (in jaren) & & & & & 3 & \# \\
\hline Werkervaring (in jaren) & & & & & 0 & \\
\hline Nu op school & & & & & 0 & \\
\hline Nu werkloos & & & & & -17 & $\#$ \\
\hline Index rekenen thuis & & & & & 8 & ** \\
\hline Percentage verklaarde variante $\left(100 * R^{2}\right)$ & 4 & & 18 & & 29 & \\
\hline$N$ & 310 & & 310 & & 310 & \\
\hline
\end{tabular}

Bron: PIAAC. Resultaten zijn ongestandaardiseerde regressiecoëfficiënten

${ }^{* *} p<.01{ }^{*} p<.05 * p<.10$. 


\subsubsection{Cohortverschillen? Of leeftijdseffecten? Bewijs van oudere cohorten}

De tot nu toe gepresenteerde analyses maken gebruik van cross-sectionele gegevens uit een enkele steekproef. De conclusies die we uit dergelijke gegevens mogen trekken over mogelijke verklaringen van geobserveerde verschillen over de tijd zijn beperkt. De door ons geobserveerde en beschreven trends komen niet voort uit herhaalde representatieve steekproeven. Op basis van een enkele steekproef is het onmogelijk om vast te stellen of en in hoeverre de geobserveerde verschillen worden gedreven doordat mensen die in verschillende cohorten geboren zijn in een andere tijd zijn opgegroeid, of doordat cognitieve vaardigheden tussen leeftijdsgroepen verschillen. Immers, mensen die ouder zijn op een meetmoment, zijn per definitie ook in een eerder cohort geboren. Ook het gebruik van herhaalde steekproeven helpt ons formeel gezien niet verder. Er kunnen zogeheten periode-effecten optreden, doordat de omstandigheden onder welke respondenten de testen maken per periode verschillen. Het empirisch onderscheiden van leeftijds-, periode- en cohorteffecten is strikt genomen onmogelijk.

Het gebruiken van herhaalde steekproeven kan ons evenwel sterkere aanwijzingen geven over de aannemelijkheid dat geobserveerde trends kunnen worden verklaard door leeftijds-, periode of cohorteffecten. Door gegevens uit verschillende surveys te vergelijken kunnen we nagaan of er bij personen die tot eenzelfde leeftijdsgroep maar een ander geboortecohort behoren, sprake is van vergelijkbare trends in cognitieve vaardigheidsniveaus. Indien de in 2013 geobserveerde verschillen vooral worden gedreven door leeftijdseffecten, dan verwachten we in Nederlandse gegevens uit eerdere geboortecohorten een vergelijkbaar patroon te kunnen observeren..$^{38}$ Indien we verschillende patronen waarnemen, dan is het een stuk aannemelijker dat er (wellicht naast leeftijdseffecten) ook cohort- of periode-effecten een rol spelen.

In deze subparagraaf vullen we de PIAAC-analyses daarom aan met analyses van IALS (verzameld in 1994) en ALL (2006) data van de OESO. In alle drie de surveys wordt de leesvaardigheid van volwassenen op vergelijkbare wijze gemeten. Om het taalvaardigheidsniveau van jongvolwassenen tussen de verschillende onderzoeksjaren zo goed mogelijk te kunnen vergelijken, hebben we de taalvaardigheidmetingen en overige variabelen uit de verschillende surveys onderling vergelijkbaar gemaakt. ${ }^{39}$ Uit deze surveys nemen we telkens een subsample van personen die tussen de 18 en 34 oud waren. Omdat de steekproeven respectievelijk in 1994, 2006 en 2013 getrokken zijn, zijn de mensen uit deze leeftijdsgroepen afkomstig uit verschillende geboortecohorten.

De eerste kolom van Figuur 6.3 toont de ontwikkelingen in genderverschillen in taalvaardigheid tussen jongere en oudere cohorten voor lager opgeleiden uit drie steekproeven. Er is duidelijk sprake van verschillende patronen tussen de steekproeven. In de gegevens van de steekproef die in 1994 is ondervraagd, is te zien dat mannen uit oudere

38 Een uitzondering hierop is, als het leeftijdseffect op leesvaardigheid tussen de geboortecohorten verschilt.

39 De vaardigheidsschalen zijn opnieuw berekend op basis van items die in alle drie de surveyjaren gevraagd zijn. De plaatjes voor de PIAAC-analyse zien er daardoor iets anders uit: de vaardigheidsschaal is op basis van andere testitems samengesteld dan in de voorgaande analyses. Bovendien waren niet alle controlevariabelen in de drie surveys op vergelijkbare wijze gemeten, waardoor de modellen iets van elkaar verschillen 
cohorten mannen iets minder taalvaardig zijn dan mannen uit jongere cohorten. Het tegengestelde lijkt te gelden voor vrouwen. De verschillen zijn echter niet statistisch significant. Voor mensen die in 2006 zijn bevraagd lijkt het patroon iets anders. Hier lijkt het erop dat zowel mannen als vrouwen die eerder geboren zijn taalvaardiger zijn dan vergelijkbare mannen en vrouwen uit latere cohorten. Hoewel de effecten sterker zijn, zijn ze ook hier niet significant. De eerder geobserveerde ontwikkeling die laagopgeleide vrouwen hebben gemaakt is dus een ontwikkeling die vooral te zien is bij de meest recent ondervraagde vrouwen, hetgeen wordt bevestigd door de onderste paneel uit de eerste kolom. Laagopgeleide vrouwen uit jonge cohorten zijn taalvaardiger dan laagopgeleide vrouwen uit oudere cohorten. De taalvaardigheid van laagopgeleide mannen is iets afgenomen tussen de cohorten.

De tweede kolom uit Figuur 6.3 laat zien dat er voor middelbaar opgeleiden geen patronen zichtbaar zijn. De taalvaardigheid van zowel middelbaar opgeleide mannen en vrouwen uit jongere cohorten is ongeveer even goed als bij vergelijkbare mannen en vrouwen uit oudere cohorten. Middelbaar opgeleide mannen zijn gemiddeld genomen even taalvaardig als middelbaar opgeleide vrouwen. Hetzelfde (gebrek aan een) patroon is zichtbaar voor mensen uit alle drie de steekproeven.

In de derde kolom wordt de ontwikkeling van cognitieve vaardigheden van hoogopgeleide jongvolwassenen uit verschillende geboortecohorten weergegeven. Zowel in 1994 als in 2013 presteren hoogopgeleide jongvolwassen mannen en vrouwen in alle cohorten hetzelfde op het gebied van taalvaardigheid. De gevonden verschillen zijn niet significant. Bij de in 2006 ondervraagde hoger opgeleiden is een lichte neerwaartse trend onder vrouwen te zien. Jongere hoogopgeleide vrouwen uit dat cohort zijn iets minder taalvaardig dan hoogopgeleide vrouwen die eerder geboren zijn.

Figuur 6.3 verstevigt twee voorzichtige conclusies die wij eerder in dit hoofdstuk trokken, en biedt ruimte voor verdieping. Ten eerste zijn genderverschillen in de ontwikkeling van cognitieve vaardigheden van Nederlandse jongvolwassenen inderdaad vooral te observeren bij laagopgeleide jongvolwassenen, en dan alleen jongvolwassenen uit de jongste geboortecohorten. Het ontbreken van patronen onder laagopgeleide jongvolwassenen in oudere steekproeven versterkt de conclusie dat het hier (ook) om cohorteffecten gaat. Ten tweede moet worden opgemerkt dat het uiterst onaannemelijk is dat dergelijke cohorteffecten een rol spelen voor de verklaring van taalvaardigheid van middelbaar en hoger opgeleiden. Uit deze analyse blijkt dus niet dat tussen cohorten veranderde omstandigheden voor middelbaar en hoger opgeleiden samenhangen met hun taalvaardigheid. 


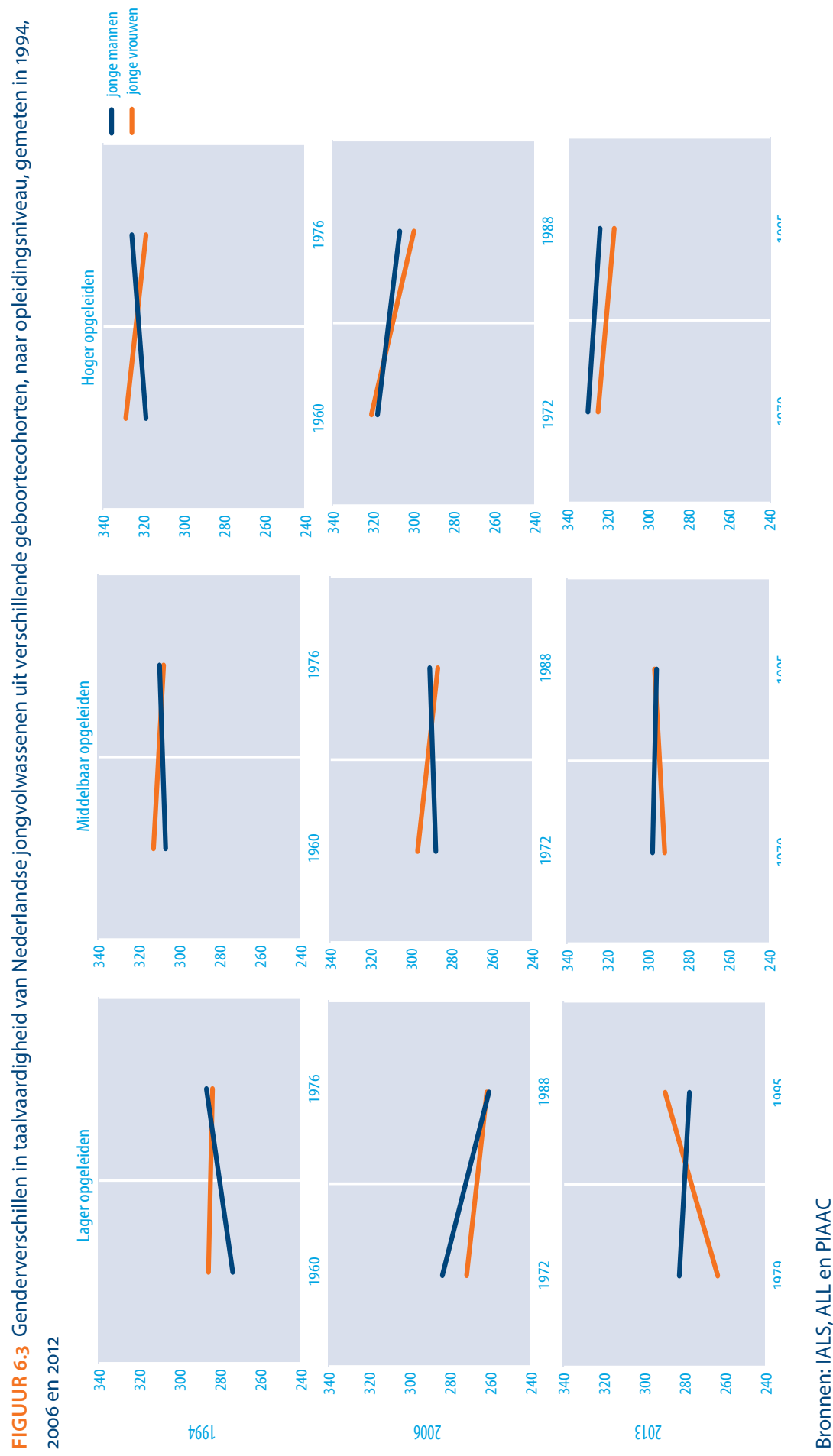




\subsubsection{Cohortverschillen? Of leeftijdseffecten? 15-jarigen uit verschillende geboorte- cohorten vergeleken}

Een tweede manier om te bezien of en in hoeverre cohorteffecten een rol spelen in de ontwikkeling van vaardigheden, is door mensen te vergelijken die eenzelfde leeftijd hebben maar die behoren tot verschillende geboortecohorten. De herhaalde steekproeven onder 15-jarigen die de OESO in het kader van PISA bieden daarvoor een goede evidence base. Indien de eerder geobserveerde toenemende voorsprong in taalvaardigheid van vrouwen ten opzichte van mannen kan worden verklaard door cohorteffecten op de gender gap in het onderwijs, dan zouden we die verschillen moeten terugzien in de vaardigheidsscores van deze mensen toen ze in het voortgezet onderwijs zaten.

Figuur 6.4 laat zien dat dit inderdaad zo is. De figuur toont op basis van PISA-gegevens voor 4 Nederlandse geboortecohorten de mate waarin 15-jarige jongens beter presteren dan 15-jarige meisjes op het gebied van reken- en taalvaardigheid. Hoe sterker positief, des te beter doen jongens het ten opzichte van meisjes. Een negatieve score betekent dat meisjes het beter doen. We hebben de resultaten opgesplitst naar scholieren die in de lagere tracks uit het Nederlandse voortgezet onderwijs (te weten: praktijkonderwijs en vmbo) en de hogere tracks (te weten: havo en vwo).40 De coëfficiënten zijn gecontroleerd voor ouderlijke sociaaleconomische achtergrond, geboorteland van vader, moeder en kind, en de thuis gesproken taal.

De twee panelen van de figuur ondersteunen de eerder getrokken conclusies. Voor 15-jarige kinderen in de lage tracks is te zien, dat de kloof in rekenvaardigheden tussen jongens en meisjes tussen 2003 en 2012 min of meer trendloos fluctueert. Maar meisjes in lagere tracks vergrootten hun oorspronkelijke voorsprong in taalvaardigheid sinds 2003 voortdurend en gestaag.

Voor 15-jarigen in de hogere, voor het hoger onderwijs voorbereidende tracks zijn dergelijke duidelijke trends niet waar te nemen. In het algemeen lijken jongens in deze tracks het zelfs beter te zijn gaan doen dan meisjes voor wat betreft rekenen. Meisjes hebben in alle vier de metingen een voorsprong in taalvaardigheid maar de verschillen zijn klein en van een duidelijke trend is geen sprake.

40 In PISA data kan geen verfijndere opsplitsing tussen tracks gemaakt worden. 
FIGUUR 6.4 De mate waarin 15-jarige jongens beter of minder goed presteren dan 15-jarige meisjes op het gebied van reken- en taalvaardigheid, naar geboortecohort

Rekenen Taa
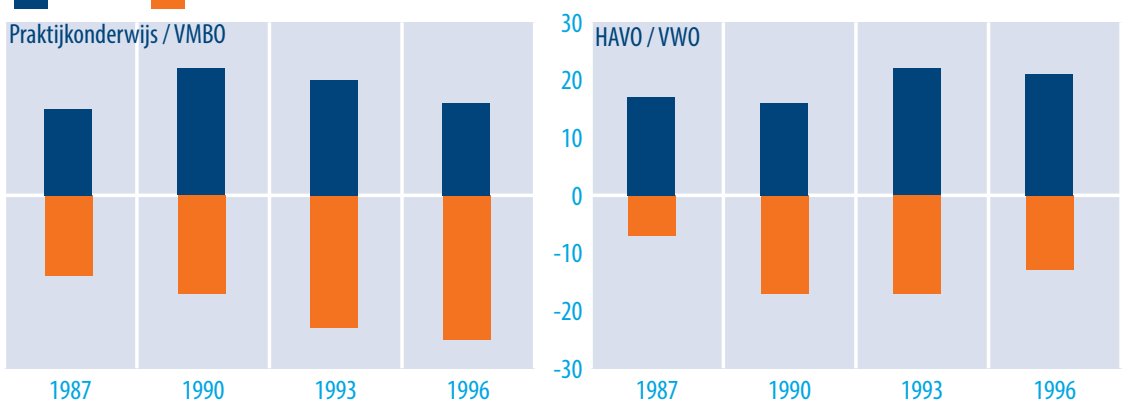

Bronnen: Nederlandse gegevens uit PISA 2003, 2006, 2009, 2012

\subsection{Discussie}

Dit hoofdstuk had tot doel te onderzoeken of en in hoeverre er sprake is van genderverschillen in de cognitieve prestaties van jongvolwassen (18-34) mannen en vrouwen met verschillende opleidingsniveaus. Hierbij werd nagegaan in welke mate eventuele gender gaps in cognitieve prestaties verschillen tussen jongvolwassenen uit verschillende geboortecohorten.

Een aanleiding voor de verwachting dat er sprake zou kunnen zijn van cohortverschillen in taal- en rekenvaardigheden is gelegen in de aanname dat mensen uit andere geboortecohorten onder andere omstandigheden onderwijs hebben genoten. In de inleiding stelden we reeds vast dat 'vrouwvriendelijke' onderwijshervormingen' in het middelbaar en hoger onderwijs er wellicht voor zouden kunnen hebben gezorgd dat de door eerder onderzoek vastgestelde voorsprong van jongvolwassen mannen voor wat betreft taal en wiskunde gedurende de laatste decennia is afgenomen. Wij vinden echter geen bewijs voor deze redenering.

Voor middelbaar en hoogopgeleide mannen en vrouwen zijn de verwachte cohorteffecten niet waar te nemen. Middelbaar- en hoogopgeleide mannen beschikken over een even goede taalvaardigheid als, en een iets betere rekenvaardigheid dan vergelijkbare vrouwen. De verwachte ontwikkeling tussen cohorten zien we niet in de data terug. De bevinding uit hoofdstuk 4 en 5 dat meer studentgerichte leeromgevingen op de korte termijn gunstiger uitpakken voor het studiesucces van meisjes, houdt dus op de langere termijn voor middelbaar- en hoogopgeleiden geen stand. Alleen onder de laagst opgeleide jongvolwassenen observeren wij genderverschillen in cognitieve vaardigheden in verschillende cohorten. Dit is zowel voor taal- als rekenvaardigheid het geval. Dat komt vooral doordat laag opgeleide vrouwen uit jongere cohorten het veel 
beter doen dan laagopgeleide vrouwen uit oudere cohorten, terwijl mannen geen of slechts een geringe stijging laten zien.

De genderverschillen in verschillende cohorten laagopgeleiden zijn maar gedeeltelijk te verklaren door variabelen die sterk met cognitieve vaardigheden samenhangen, zoals sociaaleconomische achtergrond, etniciteit, werkervaring, arbeidsparticipatie, en de toepassing van cognitieve vaardigheden thuis. Bovendien laten aanvullende vergelijkingen van verschillende cohorten zien dat het aannemelijk is dat geobserveerde genderverschillen onder laag opgeleiden in ieder geval deels kunnen worden toegeschreven aan cohorteffecten.

Een belangrijke vraag die de onderzoeksresultaten in dit hoofdstuk evenwel oproepen is waarom er onder laagopgeleide jongvolwassenen wel sprake is van een genderverschil in cognitieve vaardigheden in verschillende cohorten en niet bij middelbaar en hoogopgeleiden. Het is mogelijk dat de'vrouwvriendelijke' onderwijsveranderingen die in de afgelopen decennia in het primair en voortgezet onderwijs zijn doorgevoerd een sterkere impact hebben op de cognitieve prestaties van laagopgeleide jonge mannen en vrouwen dan op de prestaties van middelbaar of hoger opgeleiden equivalenten. $\mathrm{Er}$ is een aantal redenen waarom dit het geval zou kunnen zijn. Ten eerste heeft onderzoek aangetoond dat de schoolomgeving in het algemeen, en dus ook veranderingen in de schoolomgeving, een grotere impact heeft/hebben op de cognitieve prestaties van lage presteerders dan op die van hogere presteerders (Kyriakides \& Creemers, 2011). Dit zou impliceren dat de 'vrouwvriendelijke' onderwijshervormingen van de laatste decennia een positievere impact hebben gehad op de prestaties van laagopgeleide vrouwen, en een negatievere impact op de prestaties van laagopgeleide mannen, dan hun hoger opgeleide leeftijdgenoten. Ten tweede zijn er aanwijzingen dat de ontwikkeling naar meer feminiene leeromgevingen een sterkere impact op de cognitieve prestaties van laagopgeleide mannen hebben gehad dan op die van hoogopgeleide mannen. Dit is omdat laagopgeleide mannen zich sterker zouden afzetten tegen de meer 'feminiene vaardigheden' die in de nieuwe leeromgevingen worden vereist, dan hoger opgeleide mannen (Legewie \& DiPrete, 2012).

\section{BELEIDSAANBEVELING}

- De bevinding dat dat de achterstand in taalbeheersing en rekenvaardigheden onder de laagst opgeleide jongens het grootst is, is niet alleen zorgelijk maar vraagt ook om specifiek beleid ten aanzien van deze groep. Deze bevinding zou er op kunnen duiden dat de laagst opgeleide jongens wellicht de minste mogelijkheden hebben om zich aan te passen aan voor hen ongunstige leeromgevingen, hetgeen het aanleren van kerncompetenties bemoeilijkt. Dat zou betekenen dat de laagst opgeleide jongens in toenemende mate achter zouden kunnen geraken, zowel ten opzichte van oudere jongens en mannen, als ten opzichte van tot hun eigen generatie behorende meisjes. Wij achten dit een urgent onderwerp voor verder onderzoek. 


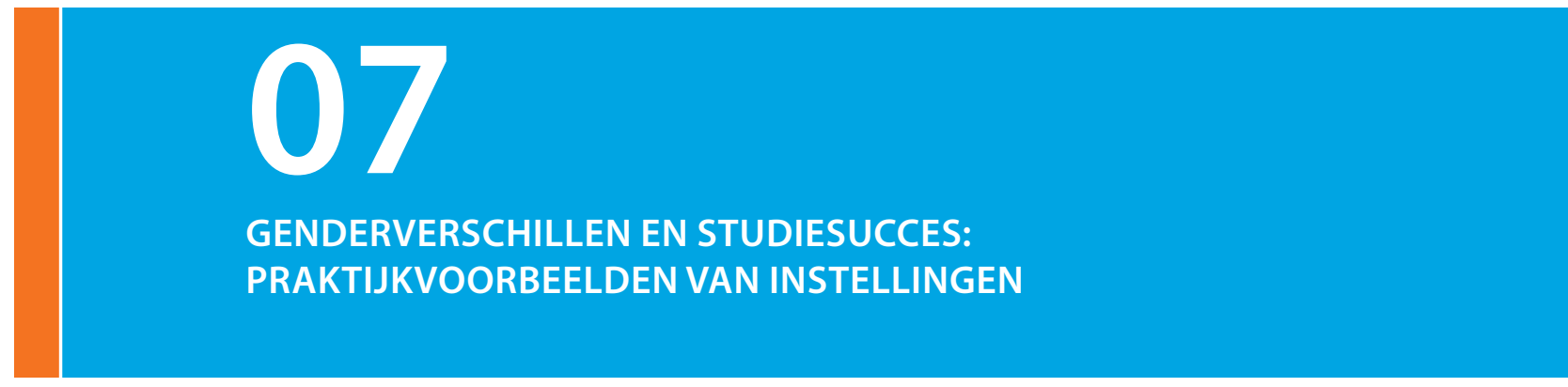

\section{Renze Kolster en Hans Vossensteyn \\ (CHEPS) \\ Marloes de Hoon en Mark Levels \\ (Researchcentrum voor Onderwijs en Arbeidsmarkt)}

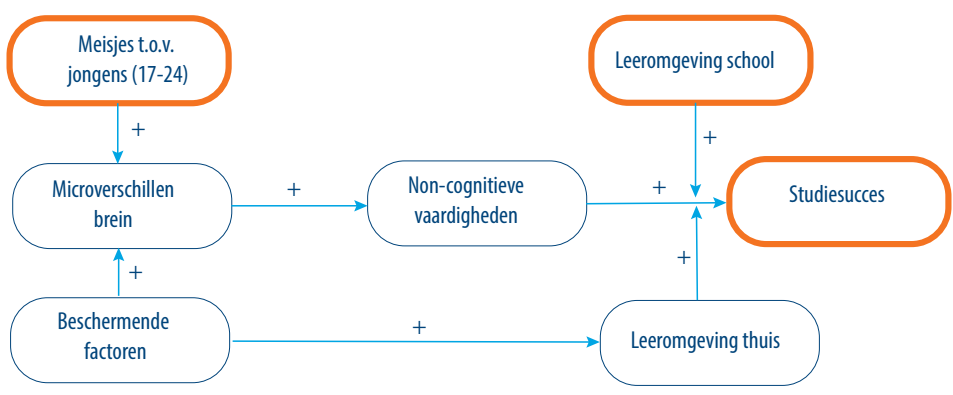

\section{Samenvatting}

In de voorgaande hoofdstukken zijn mogelijke verklaringen voor de geobserveerde verschillen in studiesucces tussen jongens en meisjes besproken. Het vorige hoofdstuk heeft aangetoond dat leeromgevingen invloed kunnen hebben op cognitieve prestaties van met name lage presteerders alsmede laagopgeleide mannen. Dit betekent dat beleid op leeromgevingen van invloed kan zijn op verschillen in studiesucces. Beleidsinstrumenten worden echter pas ingezet als hiertoe een noodzaak is. Daarom is in dit hoofdstuk allereerst onderzocht of de verschillen in studiesucces in Nederland en in het buitenland als probleem worden beschouwd. De case studies ${ }^{41}$ laten zien dat in Nederland de mate waarin de verschillen ervaren worden als probleem uiteenlopen per instelling (bij zowel mbo als ho-instellingen) en per niveau binnen instellingen. Op centraal instellingsniveau worden de verschillen gesignaleerd. Hierbij is wel variatie in diepte van monitoring te onderscheiden (bijv. enkel monitoring van instroomverschillen vs. monitoren van studiesuccesresultaten naar geslacht en achtergrond). Hoe

41 De in de case studies gevonden praktijkvoorbeelden zijn gebaseerd op zelfrapportages door de geïnterviewde vertegenwoordigers van instellingen, faculteiten / sectoren en studieprogramma's. De omschrijvingen en uitkomsten van de voorbeelden zijn niet verder geverifieerd en gevalideerd. 
dichterbij een vertegenwoordiger van een instelling bij de studenten staat (bijv. studiebegeleiders) hoe meer inzichten in de verschillen worden genoemd. De opgemerkte verschillen zijn bijvoorbeeld dat jongens over het algemeen een hogere uitval hebben en meer moeite hebben met planvaardigheden. Door de discrepantie in probleemherkenning naar niveau verschilt ook de probleemperceptie. In het buitenland varieert de probleemperceptie van studiesucces in het algemeen, alsmede de gender verschillen daarbinnen. De meeste buitenlandse experts hebben de indruk dat gender een gematigde invloed heeft op studiesucces. Dit suggereert dat op nationaal niveau verschillen in studiesucces niet als groot probleem wordt ervaren. Aan de hand van de Nederlandse case studies kunnen we concluderen dat verschillen in studiesucces bij geen van de instellingen de hoogste prioriteit krijgt. Dit neemt niet weg dat sommige instellingen, met name bij instellingen met studieprogramma's die aanzienlijke genderverschillen in hun instroom hebben, op studieprogrammaniveau beleidsinstrumenten hebben ingezet om verschillen in studiesucces te verkleinen. Praktijkvoorbeelden van beleid dat specifiek gericht is op jongens omvatten aparte jongensklassen, jongensmiddagen, aanpassingen in het curriculum en onderwijsdifferentiatie. Het gaat bij deze praktijkvoorbeelden veelal om experimenten waarbij het effect op studiesucces niet direct gemonitord wordt. Hierdoor is vooralsnog niet eenduidig vast te stellen welke instrumenten wel of niet werken. Er kan wel gesteld worden dat het risico op negatieve neveneffecten van genderspecifieke beleidsinstrumenten sterk aanwezig is.

\subsection{Inleiding}

\subsubsection{Doel deelproject}

In de vorige hoofdstukken is ingegaan op de achterliggende factoren en mechanismen die een belangrijke verklaring kunnen bieden voor verschillen in studiesucces tussen jongens en meisjes in het hoger onderwijs en middelbaar beroepsonderwijs in Nederland. Om de bevindingen uit de literatuurstudies en de data-analyses nader te nuanceren, en ook te bezien of en in hoeverre onderwijsinstellingen er in Nederland in slagen om door middel van veranderingen in leeromgevingen de gender gap te verkleinen, wordt in dit hoofdstuk de aandacht verlegd naar de praktijk. Er is specifieke aandacht voor de wijze waarop beleid de verschillen in studiesucces tussen jongens en meisjes kan beïnvloeden. Om deze reden zijn wij binnen het middelbaar beroepsonderwijs en hoger onderwijs opzoek gegaan naar praktijkvoorbeelden waarmee het kleiner maken van de verschillen in studiesucces tussen jongens en meisjes wordt beoogd. Daarnaast is gekeken of verschillende leerprestaties tussen jongens en meisjes ook in het buitenland een rol spelen in het bepalen van de beleidsagenda voor het hoger onderwijs, en zo ja, welk beleid er dan gevoerd wordt.

Concreet gaat dit hoofdstuk in op de mate waarin instellingen verschillen in studiesucces als probleem ervaren en wat ze er door de ontwikkeling en inzet van beleidsinstrumenten aan doen. Het overkoepelende doel is dan ook inzicht te krijgen in wat 
we kunnen leren van de aanpak van instellingen om het verschil in studiesucces tussen jongens en meisjes kleiner te maken. Daarnaast zal worden gekeken of er in het buitenland inspirerende beleidsaanpakken kunnen worden waargenomen op het terrein van het verkleinen van verschillen in studiesucces tussen jongens en meisjes.

Dit hoofdstuk is ingedeeld aan de hand van de in paragraaf 7.1.2 opgesomde onderzoeksvragen. Paragraaf 7.2 gaat in op de informatie verkregen door de Nederlandse case studies. De daarop volgende paragraaf gaat in op de ervaringen met genderverschillen en studiesucces in het buitenland. In de laatste paragraaf wordt een conclusie geven waar ingegaan wordt op de overkoepelende deelvraag van het onderzoek.

\subsubsection{Onderzoeksvragen}

In dit hoofdstuk wordt de derde deelvraag van ons onderzoek beantwoord. Namelijk: Zijn er verschillen tussen mbo-, hbo- en wo-instellingen in de mate waarin studiesucces tussen jongens en meisjes verschilt en wat kunnen we leren van 'good practices'?

De bijbehorende onderzoeksvragen die hieronder vallen zijn:

- In hoeverre wordt de kloof tussen jongens en meisjes als een probleem ervaren in Nederland?

- Wat wordt in Nederland gedaan om het studiesucces van jongens in het mbo, hbo en wo te verbeteren?

- In hoeverre wordt de kloof tussen jongens en meisjes als een probleem ervaren in het buitenland?

- In hoeverre is beleid in buitenland specifiek op de jongens/meisjesproblematiek gericht?

In de case studies zijn wij op zoek gegaan naar beleid gericht op het verbeteren van studiesucces van jongens en naar (leer)contexten waarin jongens beter presteren dan zij gemiddeld doen en zo op een gelijkwaardig niveau presteren als meisjes in termen van studie-uitval, gemiddelde cijfers en/of slaagpercentages. Daarnaast hebben we gekeken of het instellingsbeleid effectief is. We hebben beleidsdocumenten en rapportages over de ingezette instrumenten geanalyseerd en geïnventariseerd of de instelling hier zelf onderzoek naar hebben gedaan. Aandacht is uitgegaan naar hoe het specifieke beleid gericht op het terrein van verschillen in prestaties tussen jongens en meisjes zich verhoudt tot de context en ander beleid. We hebben gevraagd hoe belangrijk en substantieel de ingezette instrumenten zijn en of zij worden verstrekt of tegengewerkt door andere factoren en ontwikkelingen. Op die manier kan worden ingeschat in hoeverre initiatieven op dit terrein ook als 'good practices' kunnen worden geïdentificeerd. Gegeven de complexiteit van het onderwerp, de soms tegenstrijdige berichten uit de (beleids)literatuur en het kleine aantal case studies is in de 'good practice' cases met terughoudendheid gesproken over mogelijke causale verbanden en het maken van generalisaties. In alle gevallen hebben wij het over groepen van studenten; er zijn altijd jongens die het wel erg goed doen en meisjes die het juist minder goed doen. Hiernaast 
is belangrijk op te merken dat de gevonden praktijkvoorbeelden gebaseerd zijn op zelfrapportages door de respondenten. De omschrijvingen en uitkomsten van de voorbeelden zijn niet verder geverifieerd en gevalideerd door de auteurs van dit hoofdstuk.

Om het doel van dit deelproject te bereiken zijn de onderzoeksvragen voor de Nederlandse case studies nader gespecificeerd in de volgende interviewvragen:

$\checkmark$ In hoeverre wordt de kloof tussen jongens en meisjes als een probleem ervaren door uw instelling / faculteit / opleiding?

- Welke aspecten worden daarbij meer specifiek als problematisch ervaren? (zoals participatie, studie-uitval, gemiddelde cijfers, slaagpercentages, studieduur)

Is er specifiek beleid om de kloof tussen jongens en meisjes te verkleinen?

- Bijvoorbeeld op het gebied van: participatie, studie-uitval, gemiddelde cijfers, slaagpercentages, studieduur, uitstroom naar vervolgopleiding of arbeidsmarkt.

- Om welke beleidsinstrumenten gaat het? Hoe zijn die vormgegeven? denk daarbij aan onderwijsbeleid, onderzoeksbeleid, wervingsbeleid, student-ondersteuningsbeleid of leeromgeving.

- Op welk niveau is dit beleid vormgegeven (binnen specifieke opleidingen, hele instelling, en/of in breder kader)?

- Hoe is het beleid geïmplementeerd? (bijvoorbeeld als pilot, opleidingsbreed, ...)

- Welke redenen en motieven liggen ten grondslag aan de beleidsinitiatieven?

$\checkmark$ In hoeverre is het bovengenoemde beleid dat specifiek op jongens en/of meisjes is gericht effectief?

- Is er onderzoek naar de effectiviteit van de beleidsinstrumenten gedaan?

- Zijn jongens na de inzet van de beleidsinstrumenten het gemiddeld beter gaan doen, en zo ja op welke gebieden?

- Is hierdoor het verschil tussen jongens en meisjes afgenomen (of zijn meisjes het gemiddeld ook beter gaan doen?)

$\checkmark$ Zijn er positieve en/of negatieve neveneffecten van het gevoerde beleid gericht op jongens en meisjes?

$\checkmark$ Zijn er andere variabelen of beleidsinitiatieven die volgens $u$ invloed hebben op verschillen in prestaties tussen jongens en meisjes? U kunt hierbij denken aan contextfactoren als typische mannen- of vrouwenstudies, deeltijdstudies, vooropleidingseisen. Of ander beleid: BSA, interne bekostiging, kwaliteitszorg, studiebegeleiding.

- Worden de ingezette beleidsinstrumenten gericht op jongens en meisjes versterkt of tegengewerkt door de andere factoren of beleidsinstrumenten?

\subsubsection{Case selectie}

Aan de hand van case studies is het instellingsbeleid en de mogelijke effectiviteit daarvan in kaart gebracht. Hierbij hebben wij specifiek gezocht naar 'good practices'. Om een breed scala aan beleidsinstrumenten te vinden zijn er interviews afgenomen en/of focusgroepen gehouden met vertegenwoordigers van verscheidene instellingen. Hierbij is onze aandacht uitgegaan naar verschillende hiërarchische lagen: bestuurders 
van instellingen, beleidsmakers op instellingsniveau, beleidsmakers op faculteitsniveau, op sectorniveau, onderzoekers, docenten en studiebegeleiders (zie tabel 7.1).

Voor de selectie van cases is een aantal criteria gehanteerd waar een instelling of een aangeboden opleiding aan moet voldoet. Wij hebben instellingen benaderd die aan minimaal twee criteria voldoen. De selectiecriteria zijn:

- Kleine studieprestatieverschillen tussen jongens en meisjes zoals naar voren komt uit de DUO gegevens, waarbij waar mogelijk gecorrigeerd is voor opleidingssamenstelling en etnische herkomst.42

- De aanwezigheid van actief beleid op studiesucces voor jongens en/of meisjes.

- Ervaring met verschillende onderwijsmodellen en activerende leeromgevingen, zoals probleemgestuurd onderwijs en competentiegericht onderwijs.

- Onderwijsdomeinen met een typisch jongens- of meisjesprofiel.

- Deelname van instellingen aan het Europese studiesucces project dat wordt geleid door CHEPS.43

Er zijn in totaal elf case studies uitgevoerd: drie in het wo, vier in het hbo en vier in het mbo. De volgende instellingen zijn op grond van de bovenstaande criteria geselecteerd:

\section{Universiteiten}

- Universiteit Maastricht (UM): heeft veel ervaring met het intensieve probleemgestuurd onderwijsmodel, biedt onderwijs aan in domeinen die veel meisjes aantrekken en heeft een groot aantal buitenlandse studenten wat de mogelijkheid biedt om ook de rol van migratieachtergronden (nationaliteit) te bestuderen.

- Universiteit Utrecht (UU): scoort volgens de DUO gegevens relatief goed wat betreft het verschil tussen jongens en meisjes, heeft een grote diversiteit aan opleidingen, zowel met een typisch jongens- als meisjesprofiel en heeft als case studie deelgenomen aan het Europese studiesucces project van CHEPS.

- Universiteit Twente (UT): een technische universiteit met zowel typische jongensstudies als ook typische meisjesstudies en heeft recent een nieuw onderwijsmodel geïntroduceerd.

In 2014 heeft DUO (Schaacke, 2014) berekeningen gemaakt van de verschillen in studiesucces tussen jongens en meisjes bij Mbo instellingen. Een probleem bij die analyse was dat een deel van de gevonden verschillen te maken kan hebben met de opleidingssamenstelling en studentpopulatie van de betrokken instellingen. Om een 'eerlijker' vergelijking te maken en daarmee voorbeelden te vinden van 'good practice', zijn de desbetreffende analyses herhaald, maar nu met correctie voor de samenstelling naar opleiding (domein, leerweg) en sociaaleconomische en etnische herkomst. Door middel van logistische regressiemodellen is de kans op het behalen van een diploma per instelling afzonderlijk geschat, waarbij gecontroleerd is voor bovengenoemde kenmerken van individuele leerlingen. Resultaten kunnen op verzoek worden toegezonden

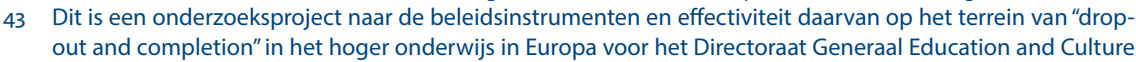
van de Europese Commissie. 


\section{Hogescholen}

- Iselinge: heeft als pabo een specifiek meisjesprofiel, maar tracht door middel van verschillende beleidsinstrumenten de leerprestatieverschillen tussen beide seksen te minimaliseren.

- Avans Hogeschool (Avans): scoort volgens de DUO gegevens relatief goed wat betreft het verschil tussen jongens en meisjes, heeft in een onderzoek aandacht gegeven aan de jongens en meisjes verschillen en experimenteert in de pabo met beleidsinstrumenten om het studiesucces van jongens te verhogen.

- Hogeschool van Arnhem Nijmegen (HAN): is een grote hogeschool met veel typische jongens- en meisjesopleidingen en heeft een Lectoraat Sekseverschillen in het Onderwijs dat initiator was van een project uitgevoerd om de verschillen in studiesucces in de pabo te verkleinen.

- Hogeschool Rotterdam (HR): is een grote hogeschool met een zeer diverse studentenpopulatie wat de mogelijkheid biedt om ook de rol van migratieachtergronden (nationaliteit) te bestuderen. HR heeft als case studie deelgenomen aan het Europese studiesucces project van CHEPS.

\section{Mbo-instellingen}

- $A O C$ Clusius (AOCC): is een instelling waarbinnen jongens volgens de gecorrigeerde DUO-cijfers het relatief goed doen voor wat betreft diplomakansen. Het is een agrarisch onderwijscentrum, met groene opleidingen waarbinnen jongens het over het algemeen goed doen.

- ROC Deltion (ROCD): biedt opleidingen aan die traditioneel worden gezien als typische jongensopleidingen (bijvoorbeeld Techniek en ICT), maar ook opleidingen die worden gezien als typische meisjesopleidingen (bijvoorbeeld Zorg en Welzijn). Voert bovendien een actief beleid om de prestatieachterstand van jongens ten opzichte van meisjes te verkleinen.

- ROC Leeuwenborg (ROCL): scoort volgens de DUO gegevens relatief goed: jongens hebben na controle voor hun studiekeuze en achtergrondvariabelen geen lagere schoolprestaties dan meisjes. De instelling biedt zowel typische jongensopleidingen als typische meisjesopleidingen aan.

- ROC Tilburg (ROCT): is een groot ROC, dat een veelvoud van typische jongens- en meisjes opleidingen aanbiedt. Er is nog geen specifiek beleid, maar er wordt op instellingsniveau nagedacht over mogelijkheden het pedagogische vakmanschap toe te spitsen op verschillen tussen jongens en meisjes.

De onderstaande tabel geeft een overzicht van welke vertegenwoordigers van de verschillende instellingen wij hebben gesproken in het kader van dit onderzoek. 
TABEL 7.1 Overzicht van gesprekspartners case studies

\begin{tabular}{|c|c|c|c|}
\hline Instellingstype & Instelling & Functie & Codering \\
\hline \multirow[t]{7}{*}{ Universiteiten } & \multirow[t]{3}{*}{ UU } & Bestuurder & UU1 \\
\hline & & $\begin{array}{l}\text { Beleidsmakers op } \\
\text { instellingsniveau }\end{array}$ & UU2 \\
\hline & & $\begin{array}{l}\text { Beleidsmakers / onderzoekers } \\
\text { op faculteitsniveau }\end{array}$ & UU3 \\
\hline & \multirow[t]{2}{*}{ UM } & $\begin{array}{l}\text { Beleidsmaker op } \\
\text { instellingsniveau }\end{array}$ & UM1 \\
\hline & & $\begin{array}{l}\text { Beleidsmakers / onderzoekers } \\
\text { op faculteitsniveau }\end{array}$ & UM2 \\
\hline & \multirow[t]{2}{*}{ UT } & $\begin{array}{l}\text { Beleidsmakers op } \\
\text { instellingsniveau }\end{array}$ & UT1 \\
\hline & & $\begin{array}{l}\text { Studiebegeleiders op } \\
\text { faculteitsniveau }\end{array}$ & UT2 \\
\hline \multirow[t]{8}{*}{ Hogescholen } & Iselinge & $\begin{array}{l}\text { Beleidsmaker / docent op } \\
\text { instellingsniveau }\end{array}$ & IS1 \\
\hline & \multirow[t]{2}{*}{ Avans } & $\begin{array}{l}\text { Beleidsmaker op } \\
\text { instellingsniveau }\end{array}$ & AV1 \\
\hline & & $\begin{array}{l}\text { Beleidsmakers / docenten } \\
\text { / onderzoeker op } \\
\text { faculteitsniveau }\end{array}$ & AV2 \\
\hline & \multirow[t]{2}{*}{ HAN } & $\begin{array}{l}\text { Beleidsmaker op } \\
\text { faculteitsniveau }\end{array}$ & HAN1 \\
\hline & & $\begin{array}{l}\text { Onderzoeker op } \\
\text { faculteitsniveau }\end{array}$ & HAN2 \\
\hline & \multirow[t]{3}{*}{ HR } & Bestuurders & HR1 \\
\hline & & $\begin{array}{l}\text { Beleidsmakers op } \\
\text { instellingsniveau }\end{array}$ & HR2 \\
\hline & & $\begin{array}{l}\text { Beleidsmakers op } \\
\text { faculteitsniveau }\end{array}$ & HR3 \\
\hline \multirow[t]{4}{*}{ MBO-instellingen } & AOC Clusius & $\begin{array}{l}\text { Beleidsadviseur } \\
\text { instellingsniveau }\end{array}$ & AOCC1 \\
\hline & ROC Deltion & $\begin{array}{l}\text { Beleidsadviseur op } \\
\text { sectorniveau }\end{array}$ & ROCD1 \\
\hline & ROC Tilburg & $\begin{array}{l}\text { Stafmedewerker op } \\
\text { instellingsniveau }\end{array}$ & ROCT1 \\
\hline & ROC Leeuwenborgh & Bestuurssecretaris & ROCL1 \\
\hline
\end{tabular}

\subsection{Genderverschillen en studiesucces in Nederland}

\subsubsection{Case studies: probleemperceptie}

Bij alle onderzochte instellingen gaat er aandacht uit naar studiesucces in het algemeen. De mate waarin de verschillen in studiesucces tussen jongens en meisjes ervaren worden als een probleem lijken te verschillen per instellingsniveau. Duidelijk is echter 
dat het bij geen van de case studies een onderwerp is dat de hoogste prioriteit heeft en dat gender gerelateerde verschillen vaak samen gezien wordt met andere achtergrondfactoren, zoals etnische herkomst / nationaliteit (HR1, UM2, ROCL1) en functiebeperkingen (bijv. autisme) (UT2, UU3, $\left.\mathrm{HR}_{2}\right)$.

Bij de hoger onderwijsinstellingen is het verschil in studiesucces bekend. Dit komt onder andere naar voren in de G5-onderzoeksrapportage over studiesucces: "Mannen vallen vaker uit in het eerste jaar, en als ze behouden blijven is er een lager rendement" (Zijlstra, et al. 2013 p. 13). De achterstand van jongens in studiesucces is in een beleidsanalyse van de Universiteit Twente reeds in 2008 gesignaleerd. Berekeningen van een universiteit laten zien dat jongens een hoger risico op langstuderen hebben (UU1). Tekenend is ook dat vooral scripties van meisjes geselecteerd worden voor de jaarlijkse scriptieprijs (UU3). Er is aangegeven dat de verschillen in de toekomst een groter probleem zullen worden. Ook in de hogescholensector is het bekend dat er verschillen zijn (Vereniging Hogescholen, 2015). "Het relatief behoorlijk achterblijven van het studiesucces bij mannelijke studenten" wordt in het instellingsplan van de HAN genoemd als een aspect waar de instelling goed op moet letten (HAN, 2012 p. 24). Hoewel het werkveld gender gerelateerde verschillen in studiesucces niet aankaart (HAN1) zijn er wel aanwijzingen van verschuivingen in gendervoorkeuren in verschillende arbeidsmarktsectoren, bijvoorbeeld in de juridische wereld waar schijnbaar steeds vaker de voorkeur wordt gegeven aan vrouwelijke werknemers ( $\left.\mathrm{HAN}_{2}\right)$. De verschillen in studiesucces, en ook de mate waarin het als probleem wordt ervaren, is duidelijker te zien op faculteitsniveau. Hier wordt immers duidelijker gezien op welke aspecten jongens verschillen.

Ook voor mbo-opleidingen geldt dat verschillen tussen jongens en meisjes worden gesignaleerd (Schaacke, 2014). Verschillen worden op het niveau van de instellingen echter niet per se als problematisch ervaren ( $\left.A O C C_{1}, R O C D_{1}\right)$. Wel zijn instellingen zich bewust van verschillen. De antwoorden op de vraag op welke aspecten jongens achterblijven of verschillen zijn weergegeven in tabel 7.2. 
TABEL 7.2 De aspecten waarop jongens achterblijven of verschillen

\begin{tabular}{|c|c|}
\hline Cluster & Kenmerken van jongens die als problematisch worden ervaren / verschillen met meisjes \\
\hline Vaardigheden & $\begin{array}{l}\text { Planvaardigheden (UT2, IS1, AV2, ROCT1) } \\
\text { Studievaardigheden (UT2) } \\
\text { Zelfinzicht (UT2) } \\
\text { Discipline (UM2, ROCL1) } \\
\text { Academische vaardigheden (UT2) } \\
\text { 21st century skills (UT2) } \\
\text { Sollicitatievaardigheden (ROCD1) }\end{array}$ \\
\hline Attitude & $\begin{array}{l}\text { Mindere intrinsieke motivatie (AV2, Geerdink, 2010) } \\
\text { Ongefundeerde optimisme ('het komt wel goed') (UT2, UM2, ROCD1) } \\
\text { Latere realisatie van noodzaak om te beginnen (UT2) } \\
\text { Achterstand door zwakkere inzet (UM2, ROCD1) } \\
\text { Vragen / aanvaarden later hulp aan / van een studiebegeleider (UM2) } \\
\text { Maken uiteindelijk meer gebruik van de studiebegeleiding (UM2) } \\
\text { Minder ambitie om meer te doen dan noodzakelijk (HAN1) } \\
\text { Moeite met schikken naar verwachtingen van opleiding (HAN1) } \\
\text { Lagere algehele interesse om te studeren (HAN1) } \\
\text { Minder volgzaam (ROCL1) } \\
\text { Verlegenheid (ROCD1) } \\
\text { Meer trial en error (ROCT1) }\end{array}$ \\
\hline Effecten & $\begin{array}{l}\text { Hebben een hogere uitval (HAN1, HAN2, HR1, IS1, AV2) } \\
\text { Blijven vaker in achterstand hangen (UM2, HAN1) } \\
\text { Doen langer over hun studie (UU1, HAN1) } \\
\text { Halen minder hogere cijfers (UT2) } \\
\text { Stromen sneller af (ROCD1) }\end{array}$ \\
\hline Overige verschillen & $\begin{array}{l}\text { Staan minder open voor feedback (Geerdink, 2010) } \\
\text { Melden zich minder vaak aan voor meerdere studies (UM2) } \\
\text { Zijn vaker te laat met aanmelden voor de opleiding (UM2) } \\
\text { Kunnen moeilijker inschatten of ze aan een eerste toetskans moeten meedoen (HAN1) } \\
\text { Attributie: meisjes zoeken tekortkomingen bij zichzelf, jongens vaak buiten zichzelf (HAN2) } \\
\text { Hebben een grotere behoefte aan het inzien van de betekenis en nut van wat ze aan het leren zijn (AV2) } \\
\text { Melden zich minder snel aan voor reductietrainingen (ROCD1) }\end{array}$ \\
\hline
\end{tabular}

Aan de andere kant hebben jongens ook kenmerken waardoor ze beter zouden kunnen presteren dan meisjes:

- Meer pragmatische inzet $\left(\mathrm{UU}_{3}, \mathrm{UT}_{2}\right)$

- Meer zelfvertrouwen (UT2)

- Rekenvaardigheden (AOCC1)

- Beter omgaan met onzekerheid (UT2)

- Minder faalangst $\left(\mathrm{UU}_{3}\right)$

- Krijgen nog altijd sneller een baan (HAN2)

Het gevolg van de aspecten waarop de jongens achterblijven is dat hun studiesucces minder is. Dit kan gezien worden als een probleem. De meeste instellingen houden het genderperspectief in de gaten in hun instroomcijfers. In de studiesuccesresultaten wordt dit, ondanks de noodzaak, niet altijd gedaan. Wanneer verschillende achtergrondkenmerken wel worden meegenomen in de analyse van studiesuccesresultaten komen 
interessante inzichten naar voren. Zo hebben enkele faculteiten van de Universiteit Maastricht het beeld dat in termen van studiesucces Duitse meisjes het beste presteren, gevolgd door Nederlandse meisjes, Duitse jongens en als laatste Nederlandse jongens (UM2). Ook de Hogeschool Rotterdam signaleert verschillen: steeds minder (28\% in 2012) allochtone meisjes uit het mbo halen hun propedeuse binnen twee jaar (tegen $58 \%$ van de autochtone meisjes uit het mbo) en slechts $13 \%$ van de niet-westerse allochtone jongens behalen een diploma binnen vijf jaar (tegen 51\% van de autochtone meisjes). ${ }^{44}$ Overigens worden de verschillen tussen jongens en meisjes in studiesucces niet overal waargenomen. Zo zegt de rechtenfaculteit van de Universiteit Maastricht geen verschil te zien (UM2). Mbo-instellingen percipiëren soms wel verschillen, maar wijzen - net als de ho-instellingen - er op dat deze waarnemingen niet altijd te generaliseren zijn (ROCL1, AOCC1).

Bij verschillende opleidingen worden er verschuivingen in instroom waargenomen. Een voorbeeld hiervan is diergeneeskunde, waar de instroom vroeger bestond uit $80 \%$ jongens, en nu uit $80 \%$ meisjes ( $U_{3}$ ). De pabo's zien het als maatschappelijk probleem dat er te weinig mannen in het onderwijs zitten (IS1, $\left.A V_{2}, H_{A N}\right)$, met als gevolg dat er scholen zijn waar helemaal geen mannen werken $\left(A V_{2}\right)$. Zij hebben dus de opdracht om meer mannen aan de opleiding te binden, te meer omdat verhoudingsgewijs jongens ook meer uitvallen en langer over hun studie doen ( $\mathrm{AV}_{2}$, IS1).

In het algemeen lijken studiebegeleiders en docenten te merken dat er een verschil zit in studiesucces (UT2, UM2, HAN1, ROCL1, ROCD1). Studiebegeleiders moeten er bij jongens harder aan trekken om te zorgen dat ze op tijd kunnen afstuderen (UM2, UT2). Ook tussen studiebegeleiders onderling wordt er in de wandelgangen wel over jongens / meisjes verschillen gesproken (UT2). Hier worden bijvoorbeeld de aspecten besproken waarop de jongens achterblijven (zie tabel 7.2).

Waar er problemen gesignaleerd worden in verschillen in studiesucces tussen jongens en meisjes gaat het bij de universiteiten vaak alleen om de bacheloropleidingen. Op master en PhD-niveau is het studiesucces van jongens niet lager dan bij meisjes (UU1, UT2). Bij een opleiding van de Universiteit Twente zijn er evenveel jongens als meisjes die de master cum laude halen, hier kunnen ook de jongens tussen zitten die gemiddeld een zes haalden in de bachelor (UT2). Misschien zijn dit de jongens die in de master juist willen laten zien dat ze het wel kunnen (UT2). Hoewel niet in detail onderzocht, wordt waargenomen dat op PhD-niveau, mannelijke promovendi het vaak zelfs beter doen $\left(U_{1}\right)$.

\subsubsection{Gender-specifiek beleid studiesucces}

In deze paragraaf wordt onderscheid gemaakt tussen: (1) contexten die van invloed kunnen zijn op verschillen in studiesucces tussen jongens en meisjes, (2) algemeen (instellings)beleid dat invloed kan hebben en (3) beleid dat specifiek gericht is op

44 Zie: 'De problemen rond studiesucces zijn indringend': http://profielen.hr.nl/2015/de-problemen-rondstudiesucces-zijn-indringend/ (geraadpleegd op 24-06-2015) 
jongens. Bij beleid wordt, waar mogelijk en relevant, aangegeven hoe het beleid is vormgegeven, of het effect heeft gehad en of het heeft geleid tot neveneffecten. We hebben eerder gesteld dat de kans dat een instelling beleid heeft geformuleerd afhankelijk is van de mate waarin verschillen tussen jongens en meisjes in studiesucces als probleem worden ervaren (zie vorige paragraaf). We zien dat veel instellingen, in het bijzonder sommige studieprogramma's, het wel als probleem ervaren, maar hier geen specifiek beleid op hebben. Het is mogelijk dat op instellingsniveau geen specifieke aandacht aan jongens / meisjes wordt gegeven, maar op faculteits- of opleidingsniveau wel. Er is ook opgemerkt dat onderscheid maken tussen jongens en meisjes een gevoelig onderwerp is, dat bedachtzaam benaderd moet worden (UU1). Een specifieke aanpak kan misschien onvermijdelijk worden, maar de vraag is wel of dit wenselijk / gerechtvaardigd is (UU1, $\mathrm{UM}_{2}, \mathrm{UT}_{2}, \mathrm{HAN} 2$ ) en of een generiek beleid niet effectiever zou zijn (HR1, Zijlstra et al., 2013).

Uit de case studies is gebleken dat er toch wel al specifieke beleidsinstrumenten worden ingezet, hoofdzakelijk bij de hogere pedagogische opleidingen (pabo). In dit domein zijn dan ook de verschillen in studiesucces, in vergelijking met andere opleidingen, het grootst (HAN2, AV2, Geerdink, 2010). De verschillen zijn het kleinst in technische opleidingen (Geerdink, 2010). Ook op mbo's worden bij verschillende opleidingen specifieke beleidsinterventies gedaan. Hier is niet alleen aandacht voor achterblijvende jongens, maar wordt tegelijkertijd aandacht besteedt aan het onderpresteren van meisjes in de technische opleidingen (ROCD1).

\section{Context}

In de gesprekken met instellingen zijn verschillende contextfactoren genoemd die indirect invloed hebben op het studiesucces van jongens en meisjes. Zo is de instroomtoename van meisjes in wiskunde (van 10\% tot $40 \%$ ) misschien niet zozeer het gevolg van beleid, maar meer van maatschappelijk factoren, zoals vrouwelijke rolmodellen in de media (UU3). Beeldvorming speelt een belangrijke rol. Dit wordt gezien als een reden voor een lagere instroom van meisjes (bijv. in technische studies) of jongens (bijv. in pabo: IS1). Nationaal beleid kan ingezet worden om de beeldvorming te veranderen. Een voorbeeld is het platform bèta-techniek, dat meisjes en jongens probeert te interesseren in gerelateerde studies en een positief effect op de instroom lijkt te hebben (UU1). Overigens is de keerzijde dat technische studies als moeilijker worden ervaren, waardoor er een hogere kans is op studievertraging (UT1). Dit kan op geaggregeerd niveau een verklaring zijn voor het achterblijvende studiesucces van jongens, zij doen immers vaker een technische studie. In het mbo lijken veel prestatieverschillen tussen jongens en meisjes verklaard te worden door zelfselectie in opleidingen. Sommige (met name technische) opleidingen zijn aantrekkelijker voor jongens, en andere (met name zorgopleidingen) voor meisjes (AOCC $1, \mathrm{ROCL}_{1}, \mathrm{ROCT}_{1}$ ). Het studiekeuzemoment kan ook gezien worden als een contextfactor (Geerdink, 2010); studenten moeten al vroeg in hun leven keuzes maken. De vraag is of meisjes en vooral ook jongens - gezien de latere rijping van het brein - hier klaar voor zijn ( $\left.\mathrm{HAN}_{1}, \mathrm{HAN} 2\right)$. Dit zou een verklaring kunnen 
zijn voor de hogere uitval en regelmatigere wisseling van opleiding onder jongens (HAN1).

De Nederlandse studiecultuur is ook een contextfactor die mogelijk invloed heeft op de verschillen in studiesucces. De zesjescultuur lijkt in de beeldvorming vooral een jongenseigenschappen, maar komt in de praktijk ook zeker voor bij meisjes (UU3). Opvallend is dat de studiecultuur positief beïnvloed kan worden door buitenlandse studenten die vaker streven naar een hoger cijfer $\left(\mathrm{UU}_{3}\right)$. Studentenactivisme is ook onderdeel van de Nederlandse studiecultuur. Echter wordt dit niet gezien als legitieme verklaring voor verminderd studiesucces: de activiteiten moeten prima naast de studie te doen zijn (UT2). Hoewel wellicht instelling en faculteit afhankelijk, lijkt er geen verschil te zijn in de interesse in activisme tussen jongens en meisjes (UT2).

Bekend is dat de verschillen in studiesucces ook in het voortgezet onderwijs (UM1) en in het buitenland ( $\mathrm{UU}_{1}$ ) voorkomen. Het is dus niet iets wat enkel speelt in het hoger onderwijs, wat suggereert dat het een issue is van het gehele onderwijssysteem (UU1). Vraag is dan ook in hoeverre er iets door middel van (instellings)beleid aan gedaan kan en moet worden. Misschien is een generiek beleid juist beter ( $\left(\mathrm{UU}_{1}\right)$.

\section{Algemeen (instellings)beleid}

Een belangrijk beleidsinstrument dat invloed kan hebben op verschillen in studiesucces tussen jongens en meisjes is het door de instelling gehanteerde onderwijsmodel (zie ook hoofdstuk 2). Bij de Universiteit Utrecht wordt het onderwijsmodel gezien als een mogelijke verklarende factor voor de, in vergelijking met andere instellingen, goede studieresultaten van zowel jongens als meisjes $\left(\mathrm{UU}_{1}\right)$. Het model is gericht op kleinschaligheid, met aandacht voor het individu, maar niet voor een bepaalde sekse (UU1). De kleinschaligheid geeft een grotere sociale controle en een meer persoonlijke benadering (in tegenstelling tot anoniem in een grote groep zijn). De voortgang van studenten wordt in het Utrechtse model continue getoetst. De Universiteit Maastricht hanteert het probleemgestuurd onderwijsmodel (PGO). Studenten werken hierin samen in groepen, wat ook gezien kan worden als kleinschalig onderwijs. De groepen worden heterogeen gemaakt door studenten met verschillende achtergronden bij elkaar te zetten. ${ }^{45}$ Hier is echter geen aandacht voor een gelijke sekseverdeling (UM2). Ook in andere aspecten van PGO is geen specifieke aandacht voor jongens of meisjes. De universiteit gaat ervan uit dat dat zowel jongens als meisjes weten van het Maastrichtse onderwijsmodel. De studenten die op basis hiervan besluiten om in Maastricht te studeren geven vaker aan dat ze de studie weer zouden kiezen (UM2). Een onderwijsmodel dat aansluit bij de verwachtingen kan dus gezien worden als belangrijk. Overigens kan het wel zo zijn dat aspecten van het PGO-model minder goed aansluiten bij wat jongens willen of kunnen. Studenten moeten bijvoorbeeld veel zaken op orde hebben, zoals bewijs van aanwezigheid en een voldoende voor voortgangstoetsen, voordat ze de studiepunten voor een gehele module krijgen. Dit vraagt discipline en planning, waar over

45 Dit wordt ook gedaan door Hogeschool Rotterdam. Als het niet gedaan zou worden dan zouden studenten met gelijke achtergronden elkaar opzoeken ( $\left.\mathrm{HR}_{3}\right)$. 
het algemeen jongens minder sterk in zijn (zie tabel 7.2). Aan de andere kant, kan het model juist doordat er discipline en planning wordt gevraagd, een verklaring zijn voor de toch goede resultaten op studiesucces gebied, van zowel jongens als meisjes. Binnen het nieuwere Twents onderwijsmodel (TOM) van de Universiteit Twente is bij de opzet geen onderscheid gemaakt tussen jongens en meisjes (UT1). Volgens een studieadviseur biedt TOM wel meer de mogelijkheden om studievoortgang van individuele studenten te volgen, waar vervolgens studiebegeleiding op maat op kan worden ingezet (UT2).

De onderwijsmodellen zullen niet altijd aansluiten op hoe jongens het liefste leren. Sommige willen bijvoorbeeld graag liever zelf aan de slag met de stof, zonder dit in groepjes te doen $\left(\mathrm{UU}_{3}\right)$. In veel mbo-instellingen is geëxperimenteerd met competentiegerichte onderwijsvormen, waarvan wel is gesuggereerd dat de leeromgevingen beter aansluiten bij de leerstijlen van meisjes (zie Hoofdstuk 4 van dit rapport). Geen van de ondervraagden bij mbo-instellingen verbindt de invoer van competentiegerichte kwalificatiedossiers echter aan prestatieverschillen tussen jongens en meisjes. Bij sommige instellingen leeft wel de indruk dat het competentiegericht onderwijs voor meisjes anders uitwerkt dan voor jongens, maar systematische gegevens ontbreken (ROCT1). Het is ook de vraag in hoeverre het onderwijs aansluit bij de belevingswereld van studenten, zo is het toepassen van ICT mogelijkheden in het hoger onderwijs nog beperkt (UT2, HAN1). Terwijl dit misschien zeker voor jongens wenselijk zou zijn (HAN1). Het blijft uiteraard erg moeilijk om de daadwerkelijke invloed van onderwijsmodellen op verschillen in studiesucces te meten. Nadere inzichten hierover zouden wel zeer waardevol zijn (UU3).

Hoewel de relatie met studiesucces van jongens en meisjes niet vaststaat, kan het beleid van instellingen om een evenwichtig sekseverdeling te hebben in docententeams / vakgroepen wel genoemd worden. Zo streeft een faculteit er na om in ieder geval een man in sollicitatiecommissies te hebben (UU2) en noemen Universiteit Maastricht en Twente op instellingsniveau aandacht te besteden aan het krijgen en behouden van vrouwen in wetenschappelijke functies (UM2, UT1). Hier is het uitgangspunt dat diversiteit groepen beter maakt (UU1).

Vergelijkbaar met het bovenstaande zijn wervingsinitiatieven om de instroom van jongens of meisjes te vergroten. Er wordt vaak gestreefd naar een gelijkere verdeling binnen de opleiding, om te voorkomen dat er jongens of meisje gedomineerde groepen ontstaan hetgeen tot negatieve compositie-effecten kan leiden. Dit hangt samen met de observatie dat niet alleen de hoogste cijfers een goede voorspeller zijn voor goede studenten, zeker niet in de masterfase. Ook kan een teveel aan vrouwen de groepsdynamiek beïnvloeden (UT2, IS1). Vandaar dat verschillende instellingen proberen via speciale evenementen of activiteiten meisjes geïnteresseerd te krijgen in technische studies (UT1,

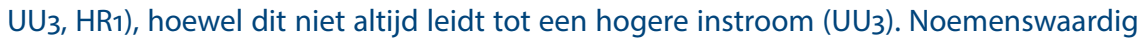
zijn in dit verband de inspanningen om jongens geïnteresseerd te krijgen in de pabo $\left(H R_{1}, I S_{1}\right)$. Om dit te bewerkstelligen zijn bij open dagen $\left(A V_{2}, I_{1}\right)$ en intakegesprekken $\left(A V_{2}\right)$ vooral ook jongens ingezet, en dit heeft effect gehad op de instroom van jongens 
(IS1, AV2). Er kan ook voor worden gewaakt dat opleidingen niet typische mannen- of vrouwenstudies worden (UU3, UT2). Een studiebegeleider merkt hierover op dat als gemerkt wordt dat het aantal aanmeldingen van jongens terugloopt, gekeken wordt of de voorlichting nog aansluit op wat jongens prikkelt (i.e. spannende en uitdagende studie) (UT2). Naast positieve effecten op de leeromgeving, kunnen externe prikkels volgens een respondent - een overweging zijn om juist meer meisjes te werven, zij doen het immers beter, wat ten goede zou kunnen komen aan het behalen van de prestatieafspraken.

Wat betreft instroom kan selectie een rol spelen. Als de selectie tot het ho enkel plaats vindt op havo / vwo-eindcijfers, zouden (autochtone) meisjes in het voordeel kunnen zijn. Mede om deze reden hanteren opleidingen met decentrale selectie naast de vo-eindcijfers ook andere indicatoren. Uit navraag bij de psychologie-opleiding van de Universiteit Maastricht blijkt dat toepassing van de verschillende decentrale selectie indicatoren niet heeft geleid tot minder geselecteerde jongens ten opzichten van het gewogen lotingssysteem. Bij een universitaire opleiding met een aanzienlijk hogere instroom van meisjes wordt bekeken of er door middel van decentrale selectie gestuurd kan worden op het toelaten van meer jongens. Ook bij een opleiding van de Universiteit Twente wordt er voor gewaakt dat er met decentrale selectie de genderbalans gehandhaafd kan blijven (UT2). De wiskunde- en taaltoets in de pabo, die plaatsvinden voorgaande aan de daadwerkelijke instroom, heeft een positief effect gehad op studiesucces, want het heeft de uitval van zowel jongens als meisjes verminderd (IS1).

In de context van studiesucces noemen vele instellingen hun matchingactiviteiten. De activiteiten moeten er voor zorgen dat de juiste studenten bij de juiste studie terecht komen. Inzichten in de prestaties van studenten worden door een faculteit van de Universiteit Maastricht gebruikt om de werving- en matchingactiviteiten af te stemmen. Hierdoor kunnen bepaalde groepen gewaarschuwd worden voor te verwachten hindernissen in hun studie en uitgenodigd worden voor een bijspijkercursus. Van studenten uit bepaalde landen is, bijvoorbeeld, bekend dat hun wiskundeniveau niet altijd aansluit bij hetgeen gevraagd door de opleiding (UM2). De matchingactiviteiten kunnen richtinggevend zijn in de verwachtingen die studenten hebben. Het kan ook een positief effect hebben op studiesucces, doordat studenten die gewaarschuwd zijn harder gaan werken (UM2). Wat opvalt is dat het met jongens moeilijker is om afspraken te maken voor matchingsactiviteiten $\left(\mathrm{UT}_{2}, \mathrm{UU}_{2}\right)$. De rechtenfaculteit van de Universiteit Maastricht ziet door de matchingsactiviteiten de eerstejaarsrendementen toenemen (UM2). Vaak wordt hetgeen is opgemerkt tijdens de matchingsactiviteiten (bijv. motivatieproblemen of functiebeperkingen) meegenomen in de studiebegeleiding (UT2, $U_{2}, U_{2}, A V_{2}, H_{3}$ ).

De instellingen noemen ook de rol van studiebegeleiding in studiesucces, met name in het eerste jaar. De aandacht voor eerstejaarsstudenten kan verband houden met het bindend studieadvies (BSA). Genoemde instrumenten die hier betrekking op hebben zijn: (vaste) tutoren $\left(U_{3}, U_{2}\right)$, mentorgroepjes (UM2), vaste studieadviseurs (UT1), (éénop-één) trainingen in studievaardigheden (UT2), individuele en gemeenschappelijke 
bijeenkomsten $\left(\mathrm{AV}_{2}\right)$, peer mentoren $\left(\mathrm{AV}_{2}, \mathrm{HR}_{2}\right)$, doelgroep specifieke peer coaches (naar herkomst, niet naar geslacht; HR2), gespecialiseerde mentoraten (bijv. voor alleenstaande moeders, $\mathrm{HR}_{1}$ ), mannelijke studiebegeleiders voor jongens (IS1), toespitsing van begeleiding op jongens ( $\left.A V_{2}\right)$, en het aanstellen van zowel mannelijke als vrouwelijke vertrouwenspersonen (ROCL1). In alle vormen worden studenten die achterblijven gewezen op de mogelijke consequenties. Mentoren moeten niet enkel zien en horen, maar ook de studenten aanspreken op prestaties (HAN1). Een experiment binnen twee opleidingen van de Hogeschool Rotterdam, waar een groep een vast hoofddocent kreeg toegewezen heeft gezorgd voor een grotere groepsbinding. Hierdoor zijn de rendementen omhoog gegaan (HR3).

Opvallend is dat genderproblematiek niet altijd door docenten als problematisch wordt ervaren (ROCT1). Een specifieke, met studiebegeleiding samenhangende beleidsmaatregel betreft daarom het bieden van trainingen aan docenten. Het ROC Deltion College organiseert bijvoorbeeld regelmatig trainingssessies waar docenten van verschillende opleidingen binnen de sector techniek het gesprek met elkaar aangaan over de mogelijk verschillende aanpak van jongens en meisjes in de dagelijkse praktijk. Vaste onderwerpen tijdens zulke intervisies vormen het schoolklimaat, didactiek, pedagogiek, voorlichting en intake, die vanuit genderperspectief worden benaderd. Tijdens de sessies wordt een positieve insteek gekozen, en worden docenten uitgedaagd met elkaar na te denken over hoe zij hun onderwijs meer kunnen afstemmen op eventuele sekseverschillen in de wijze waarop kinderen leren. Daarbij worden verschillen tussen jongens en meisjes niet als onoverkomelijk probleem benaderd, en wordt uitdrukkelijk gekozen voor een niet-normatieve benadering van verschillen tussen jongens en meisjes. Verschillen in temperament en leerstijlen worden benaderd als mogelijkheden die desgewenst kunnen worden aangewend om leerlingen beter te motiveren. Doordat docenten zich meer bewust zijn van verschillen tussen meisjes en jongens en deze verschillen op een neutrale wijze benaderen, ontstaat meer begrip voor specifieke uitdagingen waarmee jongens en meisjes in het onderwijs kampen. Het programma wordt nu geëvalueerd. Eerste kwalitatieve observaties van beleidsmedewerkers lijken erop te wijzen dat het programma een voorzichtige attitudewijziging bij docenten teweeg kan brengen, waarbij meer begrip ontstaat voor gedrag dat als "typisch jongensgedrag" kan worden omschreven (ROCD1).

Vaak zijn er geen vastgestelde protocollen of specifiek beleid op studiebegeleiding voor jongens of meisjes (UT2, UM2, HAN1). Maar onbewust of gebaseerd op ervaring kunnen studiebegeleiders wel een aanpak kiezen die meer aansluit op jongens, bijvoorbeeld door ze nauwlettender te volgen en gewenste verbeteracties vaker te itereren $\left(\mathrm{UT}_{2}, \mathrm{UM} 2, \mathrm{ROCL} 1\right)$. Uit onderzoek is bekend dat meisjes een persoonlijke benadering (vertrouwensband en een goede relatie gericht op voortgang) met studieloopbaanbegeleiders heel belangrijk vinden, terwijl jongens een zakelijkere benadering (horen dat ze het goed doen) belangrijker vinden (Geerdink, 2010). De instrumenten in het eerste jaar kunnen juist voor jongens erg zinvol zijn, maar wat opvalt is dat meisjes er vaker aan deelnemen (UT2, HR2, ROCD1). Het verplichten van deelname aan studiebegeleiding 
zou een mogelijkheid zijn om het studiesucces van verschillende groepen te verbeteren (HR2). Een schaduwkant van de extra aandacht in het eerste jaar door middel van diverse instrumenten is dat het beperkend kan werken op het bereiken van het gewenste hbo of wo-niveau (IS1), tenzij de begeleiding gericht is op het zelfsturend maken van studenten (Geerdink, 2010). Ook kan niet alles opgelost worden door studiebegeleiders; er zal altijd enige uitval zijn (HR2).

Gerelateerd hieraan zijn mogelijkheden om wervingsactiviteiten voor bijvoorbeeld trainingen aan te passen aan verschillende voorkeuren van jongens en meisjes. In een mbo-instelling werd waargenomen dat reductietrainingen, bedoeld om af- en uitstroom tegen te gaan, vooral werden bezocht door meisjes, terwijl jongens vaker af- en ongediplomeerd uitstromen. De terughoudendheid bij jongens de training te volgen werd voor een deel veroorzaakt doordat wervingsactiviteiten voor deze trainingen in een voor jongens minder aantrekkelijke vorm gegoten werden. Een bewustwordingscampagne heeft communicatiemedewerkers die verantwoordelijk zijn voor de werving van deze verschillen bewust gemaakt (ROCD1).

Met het oog op het bindend studieadvies is het inzetten van de instrumenten in het eerste jaar erg zinvol, want in de oude situatie ging een grote groep mannelijke studenten pas in het tweede jaar effectief te studeren (UT2). Het BSA heeft dus geholpen om prioriteiten te stellen en deze te communiceren aan potentieel achterblijvende studenten. Vraag is wel of door het BSA ook niet de studenten, waaronder ook zeker jongens, de studie verlaten die het wel zouden kunnen, maar er qua persoonlijke vorming nog niet aan toe waren (UT2, $\mathrm{HAN}_{1}$ ). Voor studenten die niet voldoen aan de eisen van het BSA, maar wel actief hebben deelgenomen aan studiebegeleiding, kan bezien worden of ze op basis van verzachtende omstandigheden toch door kunnen (UT2, UM2).

ROC Tilburg is aan het overwegen of en in hoeverre verschillen in leerstijlen kunnen worden ingepast in een de inrichting van het bredere pedagogisch vakmanschap. Verschillen tussen jongens en meisjes zouden een onderdeel kunnen worden van een breder, opleidingsoverstijgend pedagogisch kader. De urgentie om bij het opstellen van een pedagogisch raamwerk naar genderverschillen te kijken wordt gevoeld, maar de overwegingen staan nog in de kinderschoenen.

\section{Specifiek beleid gericht op jongens}

Onder beleid dat specifiek gericht is op jongens, kunnen aparte jongensklassen worden genoemd. De universiteiten hebben hier geen ervaring mee, maar er zijn soms wel geluiden om hiermee te experimenteren (bijvoorbeeld in farmacie en diergeneeskunde) ( $\left.U_{1}, U_{3}\right)$. Verschillende pabo's hebben wel geëxperimenteerd met het bij elkaar zetten van jongens. HAN heeft ooit een aparte jongensklas gehad. Dit pakte niet goed uit, want het ging vooral om de gezelligheid en leverde niet op dat ze harder gingen werken ( $\mathrm{HAN}_{2}$ ). Iselinge heeft één jaar bewust gekozen om twee gelijk verdeelde klassen te maken, waardoor de rest van de klassen enkel bestond uit meisjes. De jongens vonden de gelijke verdeelde klassen prettig, omdat er meer dan de gebruikelijke 3 of 5 
jongens in zaten. De meisjes in de ontstaande meisjesklassen hebben het als minder prettig ervaren, want de invloed van jongens in de groepsdynamiek (bijv. relativeerde rol) werd gemist. Het is niet bekend of dit experiment heeft geleid tot een hoger studiesucces onder jongens. Na het experimentjaar, is weer overgegaan tot het indelen van klassen naar regio, dat ook praktischer is voor het doen van groepswerk. Bij de pabo van Avans is drie jaar geleden begonnen met een pilot dat inmiddels beleid is geworden. Het beleid houdt in dat: (1) jongens in ieder geval bij de stage bij elkaar zitten en waar mogelijk bij een school met mannelijke stagecoaches, (2) dat een klas uit minimaal zes jongens bestaat, zodat er na uitval nog zeker twee of drie overblijven die elkaar overeind kunnen houden en (3) dat jongens in het eerste jaar geen stage lopen in een kleuterklas, tenzij ze dit zelf willen. Uit de beleidsevaluatie is gebleken dat jongens het niet nodig vinden om met zoveel mogelijk mannen in een klas te zitten, maar wel met minstens zes andere. De stageperiode met een mannelijke collega werd als prettig ervaren. De drie beleidsinstrumenten hebben effect: de uitval van jongens is afgenomen, maar nog niet tot het gewenste niveau. Het beleid is via een lezing gedeeld met het werkveld ( $A V_{2}$ ).

Een minder intensieve vorm is om jongensmiddagen te organiseren waar mannelijke studenten uit verschillende jaren samenkomen om projecten uit te voeren, bijvoorbeeld op het gebied van planning en beroepsvoorbereiding (IS1). Dit initiatief liep één jaar, waarna het breder is getrokken, want meisjes bleken er ook interesse in te hebben. De meerwaarde van de jongensmiddagen was dat de jongens even uit de meidengroep werden gehaald. Dit stimuleerde het groepsgevoel, had een verbindend effect en gaf de jongens gelegenheid om zaken met elkaar te delen, dat ze anders niet zouden doen. Het effect op studiesucces is door de korte looptijd niet cijfermatig te onderbouwen, maar de jongens die nu in het tweede jaar zitten hebben aangegeven het graag opnieuw op te pakken.

De taligheid van de pabo's wordt gezien als mogelijke verklaring voor de slechtere studiesuccesresultaten van jongens. De opleiding bestaat veel uit reflectie en verslaglegging. Dit lijkt niet aan te sluiten bij wat jongens, op die leeftijd, goed kunnen of willen ( $A V_{2}$, Geerdink, 2010). Jongens geven, bijvoorbeeld, vaker de voorkeur aan toetsvormen waarvan het resultaat gelijk te zien is en waar minder tijd aan besteed moet worden, terwijl meisjes de voorkeur geven aan werkstukken (Geerdink, 2010). Aanpassingen in het curriculum kunnen studies meer 'jongensvriendelijk' maken ( $\mathrm{HAN} 2)$. Voorbeelden uit de pabo die hier betrekking op hebben zijn:

- Een sportvak in het eerste jaar (IS1)

- Verzwaren van de inhoud en verlichten van reflectieve aspecten (IS1, $\left.A V_{2}\right)$

- Harde aanpak in (stage)begeleiding, directere communicatie (duidelijk zeggen wat er gedaan moet worden) en het belang van reflectie uitleggen alsmede hoe dit moet (HAN2). Het project ('Meer Mans') heeft effect gehad, want meer jongens haalden hun propedeuse binnen één jaar, de cijfers voor 
stages waren hoger en jongens waren tevredener over de opleiding (HAN2). ${ }^{46}$ Aan de andere kant, vragen meisjes zich soms af waarom er zo veel aandacht uitgaat naar jongens. Aspecten van het project worden nog steeds gebruikt binnen de opleiding (HAN2), maar instellingsbreed heeft het project weinig navolging gekregen (HAN1).

Avans heeft overwogen om het curriculum aan te passen op jongens, maar uit een evaluatie bleek dat dit niet iets was waar de jongens behoefte aan hadden: ze gaven aan niet voor niets voor de pabo te hebben gekozen.

Gerelateerd aan curriculumaanpassingen, is door Iselinge geprobeerd door onderwijsdifferentiatie meer jongens aan te trekken. De opleiding kan gevolgd worden in voltijd, deeltijd, of in een academische variant. Voor de academische variant was de hoop dat het meer mannen zou aantrekken, maar dit blijkt niet het geval, want de verdeling is hetzelfde als de voltijdvariant (IS1). In de deeltijdvariant zitten wel meer mannen (50\%$50 \%)$. Verklaringen hiervoor kunnen zijn dat mannen op latere leeftijd sneller kiezen voor het basisonderwijs. Het kan ook een correctie zijn van een eerdere slechte studiekeuze of gerelateerd zijn aan de goede baankansen voor mannen in het basisonderwijs.

\subsection{Genderverschillen en studiesucces in het buitenland}

Deze paragraaf gaat in op de mate waarin verschillen in studiesucces tussen jongens en meisjes ervaren worden in het buitenland en of er daar op nationaal niveau specifiek beleid op gemaakt is. De inzichten komen voort uit een internationaal onderzoeksproject naar de beleidsinstrumenten en effectiviteit daarvan op het terrein van'drop-out and completion' in het hoger onderwijs in Europa voor het Directoraat Generaal Onderwijs en Cultuur van de Europese Commissie. Als onderdeel van dit project zijn experts uit 35 Europese landen gevraagd naar nationale studiesucces beleidsinstrumenten. Daarbij is ook expliciet gevraagd of er daarbij aandacht is voor genderverschillen. Verder zijn er in acht van de 35 landen meer gedetailleerde case studies gehouden met verschillende stakeholders en instellingen.

De onderzoeksvragen gerelateerd aan deze paragraaf zijn:

- In hoeverre wordt de kloof tussen jongens en meisjes als een probleem ervaren in het buitenland?

- In hoeverre is beleid in buitenland specifiek op de jongens/meisjesproblematiek gericht?

\subsubsection{Probleemperceptie}

We constateren dat Europese landen verschillen in de mate waarin studiesucces in het hoger onderwijs prioriteit krijgt. In het algemeen is te stellen dat landen waar gelet

46 Zie ook: 'Mannen behouden voor de Pabo': http://www.scienceguide.nl/201304/mannen-behouden-voorde-pabo.aspx (geraadpleegd op 24-06-2015). 
wordt op doelmatigheid van hoger onderwijs, ook beleid op studiesucces is geformuleerd. Wat verder opvalt is dat in veel landen er maar beperkt informatie beschikbaar is over aantallen studenten die afstuderen en aantallen studenten die uitvallen en als dergelijke informatie voorhanden is dan verschillen de definities van de indicatoren van land tot land. Aangenomen mag ook worden dat waar geen of zeer beperkte data over studiesucces beschikbaar zijn er ook geen data over verschillen in studiesucces tussen jongens en meisjes zijn. Wanneer studiesucces niet als probleem wordt gezien en waar er ook geen beleid op wordt gemaakt, ligt het voor de hand dat er ook geen aandacht is voor verschillen in studiesucces tussen jongens en meisjes. In de landen waar wel beleid is op studiesucces zien wij dat er (nog) weinig aandacht uitgaat naar verschillen in studiesucces, zowel tussen instellingen of tussen onderscheiden studentengroepen, zoals naar etniciteit of naar sekse. Veelal wordt er wel aandacht gegeven aan ongelijke instroompatronen in het hoger onderwijs. Overigens is voor alle landen data beschikbaar over de hoger onderwijsinstroom. Hieruit blijkt dat in vrijwel alle landen meer meisjes dan jongens hoger onderwijs volgen en dat deze balans net als in Nederland pas de laatste twee decennia sterk in het voordeel van vrouwen is ontwikkeld.

FIGUUR 7.1 Gender als een factor die van invloed is op studiesucces: zienswijzen van Europese experts

Niet bekend Redelijk sterke invloed

Gematigde invloed Gering invloed Geen invloed
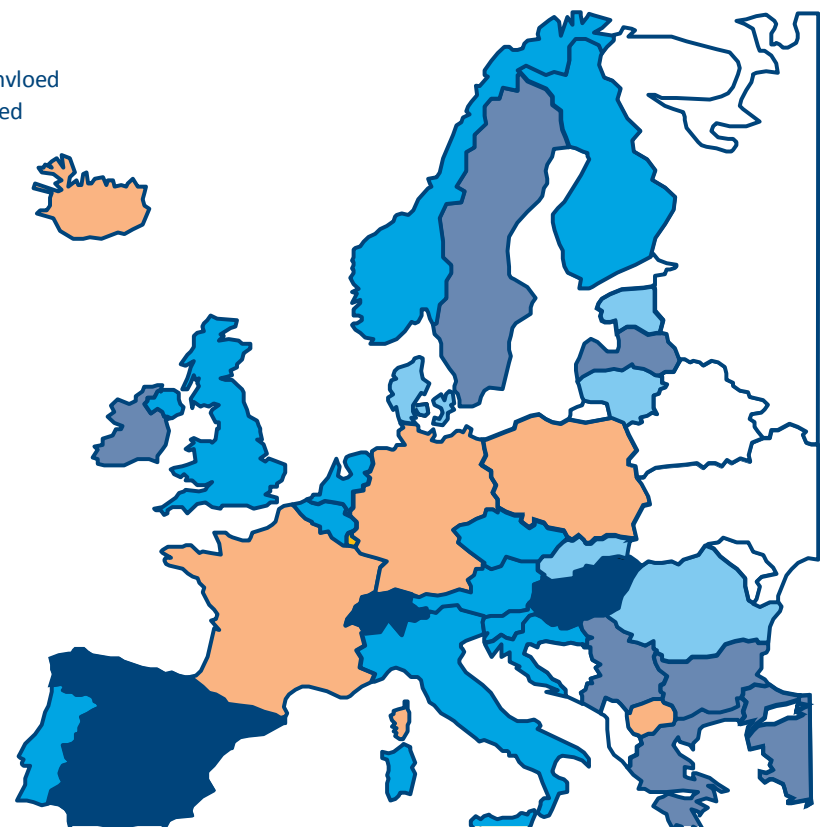

Om een indicatie te krijgen van in hoeverre de verschillen in studiesucces als probleem worden ervaren kan gekeken worden naar de mate waarin de landenexperts gender 
zien als een factor die van invloed is op studiesucces (zie figuur 7.1). De uitkomsten laten zien dat zeven experts aangeven dat gender een redelijke sterke invloedsfactor is. De meeste experts (dertien) gaven aan dat gender een gematigde invloed heeft op studiesucces. Twaalf experts zien geen of slechts een geringe invloed en drie experts hebben geen bewijs voor enig verschil gevonden.

De experts zijn gevraagd om hun indrukken nader toe te lichten. Het algemene beeld dat hier uit naar voren komt is:

- Jongens vallen vaker uit: Engeland, Estonia, Griekenland, Ierland, Italië, Kroatië, Noorwegen, Roemenië, Spanje, Turkije, Vlaanderen, Zweden, Zwitserland (13 keer genoemd).

- Jongens maken minder vaak een studie af: Denemarken, Engeland, Griekenland, Oostenrijk, Malta, Noorwegen, Servië, Tsjechië, Zweden (9 keer genoemd).

- Gender bepaalt mede de studiekeuze: Duitsland, Oostenrijk, Malta, Nederland, Noorwegen, Servië, Slowakije, Tsjechië (8 keer genoemd).

- Meisjes behalen betere studieresultaten: Bulgarije, Montenegro, Servië, Slowakije, Vlaanderen (5 keer genoemd).

- Meisjes hebben minder vaak studievertraging: Griekenland, IJsland, Servië, Slovenië (4 keer genoemd).

- Meisjes doen het beter in toelatingsexamens / in het voortgezet onderwijs: Cyprus, Polen (2 keer genoemd).

- Als meisjes uitvallen doen ze dit eerder in de studie: Oostenrijk, Zweden (2 keer genoemd).

- Meisjes doen het ook beter in technische studies: Bulgarije, Montenegro (2 keer genoemd).

- Meisjes stromen minder vaak door naar vervolgstudies (master / PhD): Malta, Oostenrijk (2 keer genoemd).

Opvallend is dat in Finland meisjes vaker uitvallen in de hogescholensector, terwijl jongens vaker uitvallen in de universiteitensector. In Vlaanderen zijn sociaaleconomische achtergrond, gevolgde voortgezet onderwijstype en gender de drie belangrijkste factoren die studiesucces beïnvloeden. In Griekenland laten statistieken zien dat jongens minder vaak hun studie afronden en vaker uitvallen. De verklaring hiervoor wordt gezocht in de extra-curriculaire activiteiten die de jongens ondernemen: ze hebben vaker een baan waarmee ze hun studie financieren. In Zwitserland zijn er weinig verschillen. Wel vallen meisjes minder vaak uit, terwijl dit voor 2000 nog omgekeerd was. In Turkije maken meisjes vaker hun studie af. Als verklaring hiervoor wordt gesuggereerd dat het afmaken van een studie belangrijker is voor meisjes, omdat dit ze in staat stelt om te emanciperen (een hogere status en economische onafhankelijkheid).

Er zijn ook experts die gender niet zien als een voorspeller voor uitval en studiesucces (Duitsland, Frankrijk, IJsland, Macedonië, Montenegro, Polen). De experts uit Hongarije, Spanje, Zwitserland geven aan dat er geen hard bewijs is voor verschillen in studie- 
succes. De expert uit Letland geeft aan dat gender een invloedrijke factor is, maar geeft eveneens aan dat er geen onomstotelijk bewijs is gevonden dat er op wijst dat jongens een verhoogde kans om uit te vallen hebben.

Het lijkt er op dat de meeste Europese landen wel verschillen in studiesucces tussen jongens en meisjes zien, maar dit niet ervaren als een belangrijke factor die van invloed is op de algemene studiesuccesresultaten. Het voorgaande is slechts een indicatie, maar het lijkt er op dat verschillen in studiesucces tussen jongens en meisjes, in de meeste Europese landen op nationaal niveau, niet als groot probleem wordt ervaren. Dit neemt uiteraard niet weg dat de probleemperceptie bij instellingen, faculteiten of opleidingen - net zoals in Nederland - er wel zou kunnen zijn.

\subsubsection{Gender specifiek beleid studiesucces}

Omdat de verschillen in studiesucces tussen jongens en meisjes lang niet overal als probleem wordt gezien, is het aantal landen waar op nationaal niveau genderspecifiek beleid is gemaakt om studiesuccesresultaten te beïnvloeden beperkt tot drie landen, namelijk Engeland, Macedonië en Zweden. Daar richt men zich veelal op de genderverschillen in de hoger onderwijsinstroom.

\section{Engeland}

Verschillende studies laten zien dat het verschil in instroom in hoger onderwijs tussen jongens en meisjes toeneemt (HEFCE, 2013). Ten opzichte van jongens, stromen er steeds meer meisjes het hoger onderwijs in. In het academisch jaar 2011/12 begonnen er 18.000 meer meisjes dan jongens in het hoger onderwijs. Om de participatiegraad in evenwicht te laten zijn zouden er 24.000 meer jongens moeten instromen, aldus het 'Department for Business, Innovation and Skills' (2014). Hoewel er geen concreet beleid genoemd wordt, moedigt het departement instellingen aan om hun dienstverlening ('outreach') toe te spitsen op jongens, vooral als zij een minder bevoorrechte achtergrond hebben.

Eveneens gerelateerd aan de instroom in het hoger onderwijs, zijn hoger onderwijs instellingen in Engeland verplicht om 'access agreements' te hebben. Sommige instellingen hebben in deze overeenkomsten genderspecifieke elementen opgenomen, zoals beleid om de instroom van een bepaalde sekse te laten toenemen. Instellingen die dit doen kunnen daarvoor erkend worden met een 'gender equality charter mark'.47

\section{Macedonië}

Om de instroom van meisjes in technische opleidingen te verhogen is de 'TECH needs girls' campagne opgestart door de Macedonische overheid, samen met de ICT Kamer van Koophandel en een technische faculteit van een universiteit. Onderdeel hiervan is het evenement 'Girls in ICT Day'. Dit evenement moet leiden tot een betere genderbalans in ICT opleidingen, door bestaande misvattingen en inaccurate percepties tegen te gaan.

47 Zie: https://www.offa.org.uk/press-releases/offa-welcomes-gender-equality-charter-mark/ (geraadpleegd op 30-06-2015). 


\section{Zweden}

Het Zweedse ministerie van onderwijs heeft in 2009 een delegatie voor gendergelijkheid in hoger onderwijs ('Delegation for Gender Equality in Higher Education') opgesteld. Met een budget van rond de 7 miljoen euro (2009-2013), hebben zij projecten van hoger onderwijsinstellingen gefinancierd. Veel van de projecten richten zich op gelijkheid in onderzoek (bijvoorbeeld gelijke verdeling van onderzoeksgelden). Slechts een paar projecten gingen in op student gerelateerde factoren, zoals genderverschillen in studiekeuzes en studiesucces (Delegation for Gender Equality in Higher Education, 2014). De projecten gericht op studiekeuzes benadrukken de belangrijke rol van docenten en studiekeuzeadviseurs in het doorbreken van genderspecifieke studiekeuzes. Trainingen zouden de docenten en adviseurs hierin kunnen ondersteunen. Wat betreft studiesucces zouden opleidingen moeten zorgen voor een curriculum dat aansluit bij zowel jongens als meisjes. Extra ondersteuning en begeleiding is nodig om te zorgen dat jongens of meisjes niet uitvallen, zeker uit studies waar geen genderbalans is.

\subsection{Conclusie}

De conclusie gaat in op de hoofdvraag van dit deelonderzoek: Zijn er verschillen tussen mbo-, hbo- en wo-instellingen in de mate waarin studiesucces tussen jongens en meisjes verschilt en wat kunnen we leren van 'good practices'?

Tussen instellingen onderling verschilt het studiesucces. Ook de resultaten van jongens en meisjes verschillen, hoewel dit soms op basis van instellingsbrede cijfers niet direct waar te nemen is. Hierdoor is het niet eenduidig vast te stellen in hoeverre mbo-, hboen wo-instellingen verschillen in de mate waarin studiesucces tussen jongens en meisjes verschilt. Duidelijk is wel dat de verschillen, bij alle instellingen, beter waarneembaar zijn op faculteits- en opleidingsniveau. Hierdoor kan het zijn dat het op instellingsniveau niet als probleem wordt ervaren, maar op de onderliggende niveaus wel. Opvallend is dat de verschillen vaak wel gesignaleerd worden, ook op instellingsniveau, maar dat - buiten de pabo's om - weinig instellingen en opleidingen specifiek beleid hebben gemaakt om de verschillen te verkleinen. Waar het als probleem wordt ervaren, worden vaak generieke beleidsinstrumenten (bijv. via het onderwijsmodel of studiebegeleiding) gezien als oplossing. Dit zijn mechanismen gericht op het versterken van de'sociale integratie' (zie hoofdstuk 2).

Het uitblijven van beleid om de gender gap in studiesucces op te lossen kan een indicatie zijn van de mate waarin instellingen het als urgent ervaren, waardoor de instrumenten om te zorgen dat jongens beter presteren nog weinig worden ingezet. Dit zou kunnen komen doordat studiesuccesresultaten door de instellingen niet altijd uitgesplitst worden naar sekse. Hierdoor valt het achterblijven van jongens minder op. Overigens is ook in het buitenland geobserveerd dat in het studiesuccesbeleid op nationaal niveau - als het er al is - weinig aandacht uitgaat naar verschillen in studiesucces. 
Gezien de verwachting van enkele respondenten dat de verschillen in de komende jaren verder zullen toenemen, kan het voor opleidingen verstandig zijn om de leerprocessen van jongens en meisjes beter in beeld te brengen. Op deze manier kan nagegaan worden wat het curriculum teweeg brengt bij degene die het volgen. Hier kunnen vervolgens genderspecifieke aanpassingen in worden gemaakt. De beschreven beleidsinstrumenten, bijvoorbeeld genderspecifieke aanpassingen in het curriculum en onderwijsdifferentiatie, kunnen hierbij inspirerend werken. Enige terughoudendheid om de specifieke beleidsinstrumenten aan te merken als good practices is geboden, want bij vrijwel geen van de instrumenten staat de effectiviteit vast. Sowieso zijn de instrumenten contextafhankelijk en kunnen ze niet zomaar één-op-één worden overgenomen. Het lijkt vervolgens aan te raden dat oplossingen gezocht moeten worden in de combinatie van instrumenten. Als door werving meer jongens instromen, die er vervolgens achter komen dat de inhoud van het programma niet aansluit bij hun verwachtingen, dan heeft de werving een averechts effect op studiesucces.

Uit de bovenstaande uitkomsten zijn de voornaamste aanbevelingen uit dit hoofdstuk te destilleren. We hebben vastgesteld dat het effect op verschillen in studiesucces van zowel generieke als genderspecifieke beleidsinstrumenten op context-, instellings- en programmaniveau nauwelijks gemeten wordt. Hierdoor is het niet verantwoord om 'good practices' specifiek te benoemen. We weten immers niet wat werkt, hoe dit komt en op wie het effect heeft. Een aanbeveling is daarom om bij beleidswijzingen op alle niveaus (bijv. in nationale voortgangseisen, in onderwijsmodellen en curriculumwijzigingen) te anticiperen, te monitoren en te evalueren of er effecten zijn op verschillen in studiesucces. Hierbij moet ook zeker aandacht uitgaan naar (negatieve) neveneffecten, zoals we gezien hebben bij beleid dat voornamelijk gericht is op jongens. Tevens moeten effecten van beleidswijzigingen bezien worden op een langere termijn. Het lijkt immers dat verschillen in studiesucces in veel mindere mate aanwezig zijn op master en PhD-niveau.

Het verkleinen van de verschillen in studiesucces hoeven niet alleen het gevolg te zijn van (specifiek) instellingsbeleid. Ook wijzigingen in de context kunnen daaraan bijdragen. Deze context is altijd in ontwikkeling. Een voorbeeld is de afnemende vrijblijvendheid van studeren, door het beperken van studiefinanciering en toenemende matchingsactiviteiten. Deze ontwikkelingen kunnen op jongens een positief effect hebben, want het stelt hun minder in staat een afwachtende houding aan te nemen. De voorgaande aanbevelingen vragen om een verdere vergroting van de bewustwording van de reeds bestaande verschillen in studiesucces tussen jongens en meisjes, in het bijzonder op instellingsniveau.

Bij het overwegen van beleidsprioriteit en beleidsinstrumenten mag niet vergeten worden dat ook andere groepen (bijvoorbeeld allochtonen) het niet altijd even goed doen in het hoger onderwijs. Verder kan de extra aandacht voor bepaalde groepen negatieve gevolgen hebben voor de beeldvorming. Zo kan door de aandacht die er is geweest voor aparte jongensklassen in de pabo, het beeld ontstaan de dat jongens het 
altijd slechter doen en dat er teveel vrouwelijke leerkrachten zijn. Dergelijke waarnemingen kunnen leiden tot onjuiste conclusies in de publieke beeldvorming. De voornaamste manier om dit tegen te gaan is zorgen voor correcte inzichten in de effecten van (beleids)ontwikkelingen.

De uitkomsten beschreven in dit hoofdstuk geven aanleiding tot het doen van vervolgstudies. Relevant zijn:

- Onderzoek naar de effecten van beleidswijzingen en beleidsinstrumenten op verschillen in studiesucces, waardoor meer inzicht wordt verkregen in welke mechanisme werken, hoe dit komt en op wie het effect heeft. Hierbij kan speciale aandacht uitgaan naar de effecten van generiek vis-à-vis genderspecifiek beleid.

- Inzichten in hoe de bewustwording van de verschillen in studiesucces vergroot kan worden en hoe onjuiste conclusies of hypotheses in de publieke beeldvorming tegengegaan kunnen worden

- Studies naar de (lange-termijn) effecten van verschillen in studiesucces op de arbeidsmarkt (zie ook hoofdstuk 2). Hierbij kan aandacht uitgaan naar het belang van een genderbalans, feminisering van beroepen, arbeidsmarktkansen, salarisontwikkelingen en voorkeuren van werkgevers in verschillende sectoren, zoals het basisonderwijs en de juridische wereld.

De aandacht in eerdere hoofdstukken lag op het stelselmatig zoeken naar verklaringen voor geobserveerde verschillen tussen jongens en meisjes, door zowel de bestaande literatuur door te nemen als data te (her)analyseren. In dit hoofdstuk hebben we beoogd deze uitkomsten te nuanceren door te kijken naar de praktijk: worden de verschillen ervaren als probleem en wat wordt hieraan gedaan? Deze uitkomsten worden in het volgende hoofdstuk in samenhang met uitkomsten van de andere deelonderzoeken besproken.

\section{BELEIDSAANBEVELINGEN}

- De overheid, instellingen en studieprogramma's is aan te bevelen om bij en na beleidswijzingen verschillen in studiesucces te anticiperen, te monitoren en te evalueren: altijd een gender component meenemen in beleidsontwikkeling en evaluaties.

- Hierbij zou niet enkel aandacht moeten zijn voor gender, maar ook voor etniciteit en sociaaleconomische achtergronden. Tevens relevant in deze zijn korte-termijn en lange-termijn effecten, alsmede onverwachte neveneffecten.

- Er kan meer aandacht gegeven worden aan het vergroten van de bewustwording van de verschillen in studiesucces, in het bijzonder op instellingsniveau. Positief is dat enkele instellingen al werken aan het vergroten van de bewustwording onder docenten, studiebegeleiders en communicatiemedewerkers. 


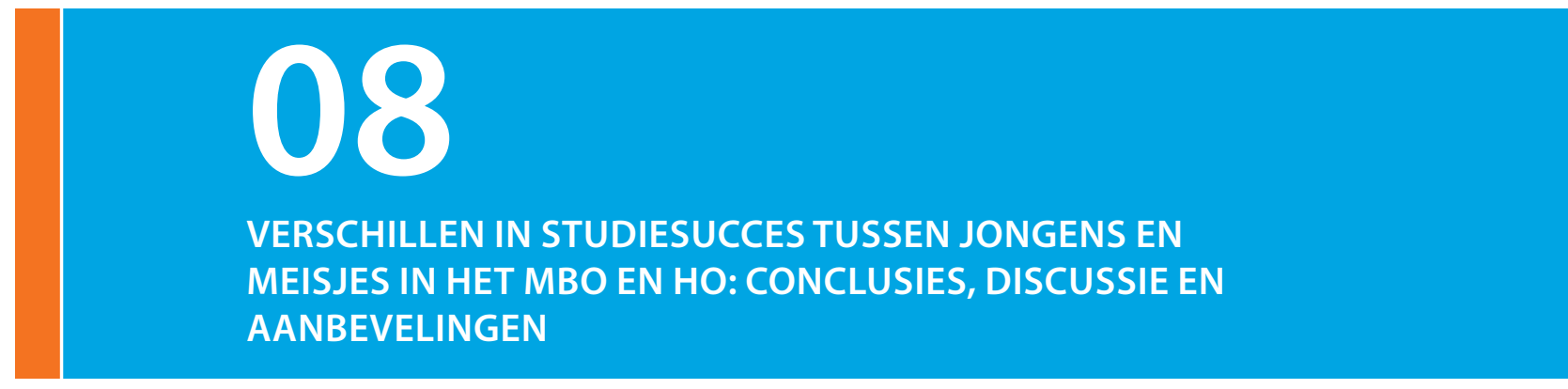

\section{Barbara Belfi, Mark Levels en Rolf van der Velden (Researchcentrum voor Onderwijs en Arbeidsmarkt) Jelle Jolles (Centrum Brein \& Leren, Vrije Universiteit Amsterdam)}

In dit rapport hebben we stelselmatig verklaringen gezocht voor de veel geobserveerde verschillen in studiesucces tussen jongens en meisjes in het postsecundair (middelbaarberoepsonderwijs; mbo) en tertiair onderwijs (hoger onderwijs; ho). Meisjes lijken het op veel succesindicatoren beter te doen dan jongens. In het mbo stromen meisjes sneller door, behalen vaker en sneller een diploma, en stromen minder vaak af naar lagere niveaus. In het hbo halen ze betere cijfers, vaker diploma's, en vallen ze minder snel uit. Ook op de universiteiten doen meisjes het gemiddeld genomen beter. Ze ronden vaker een studie succesvol af, en doen dat over het algemeen in een kortere tijd.

Het achterblijvende studiesucces van jongens ten opzichte van meisjes kan in toenemende mate rekenen op aandacht van beleidsmakers, politici en opiniemakers. Waar in de jaren zeventig en tachtig van de vorige eeuw het achterblijvende schoolsucces van meisjes als maatschappelijk probleem werd gezien, zo vindt men tegenwoordig het lagere succes van jongens problematisch. Het volgende citaat, afkomstig uit een column die Aleid Truijens op 11 juli 2015 in de Volkskant publiceerde, is illustratief voor de wijze waarop het jongensprobleem in het publieke discours is terechtgekomen. Truijens signaleert dat jongens het minder goed doen, en zoekt naar verklaringen:

"Komt het omdat het onderwijs zo talig is geworden dat jongens achterop raken? Of doordat er vrijwel alleen vrouwen voor de klas staan, die jongens lastig en druk vinden en meisjes 'gewoon'? Of is het de onderwijsvernieuwing, die meisjes past als een handschoen en jongens als extra lood aan de benen hangt? Modernisering komt er al twee decennia op neer dat leerlingen zelfstandig moeten worden en vooruit plannen, werkstukken moeten maken en moeten reflecteren op hun gedrag en vorderingen - precies de dingen waaraan veel jongens een bloedhekel hebben. De discussie hierover duurt al jaren."

De column biedt een rake beschrijving van het kennisprobleem: jongens doen het minder goed op school, maar over hoe dat komt, lopen de meningen sterk uiteen. In eerdere rapporten hebben onderzoekers uitgebreid stilgestaan bij genderverschillen in het primair en voortgezet onderwijs (Van Langen en Driessen, 2006; Driessen en Van 
Langen, 2011). Het beschikbare wetenschappelijke onderzoek naar verschillen tussen jongens en meisjes in het hoger en middelbaar beroepsonderwijs is evenwel beperkt, en bovendien versnipperd. In dit rapport hebben we geprobeerd de bestaande bronnen systematisch aan elkaar te verbinden en de systematiseren, en aan te vullen met kwantitatieve analyses van recente Nederlandse gegevens.

We voerden daartoe zes deelstudies uit. In hoofdstuk 2 verrichtten we allereerst een uitgebreid literatuuronderzoek om na te gaan welke verklaringen zoal geboden worden voor prestatieverschillen tussen jongens en meisjes, en vooral specifieke interventies in het mbo en ho effect hebben gehad op verschillen in studiesucces tussen jongens en meisjes. In hoofdstuk 3 bespraken we de meest recente bevindingen uit het neuropsychologische onderzoek naar verklaringen voor verschillen tussen jongens en meisjes. Deze verschillen werden enerzijds gerelateerd aan cognitieve en non-cognitieve functies die voor het leerproces relevant zijn en anderzijds aan studentfactoren zoals de (sociaal-culturele) achtergrond, en school- en leerervaring. Voorts onderzochten we in hoofdstuk 4 op basis van registerdata welke gevolgen de invoering van competentiegericht onderwijs (cgo) in het mbo heeft gehad voor de prestaties van jongens en meisjes. Op basis van REFLEX data, een internationaal onderzoek onder afgestudeerden van het ho, analyseerden we vervolgens in hoofdstuk 5 of verschillende leeromgevingen in het ho verschillend uitwerken op het studiesucces voor jongens en meisjes. In hoofdstuk 6 verrichtten we aan de hand van OECD-data een empirisch onderzoek naar de ontwikkeling van kernvaardigheden over de schoolloopbaan. Hoe zijn de taal- en rekenvaardigheden van jongvolwassen jongens en meisjes in het middelbaar en hoger onderwijs in de afgelopen decennia geëvolueerd? Ten slotte analyseerden we in hoofdstuk 7 aan de hand van een aantal uitgebreide case studies of onderwijsinstellingen in het mbo, hbo en wo zich bewust zijn van de verschillen in leerprestaties tussen jongens en meisjes en of ze erin slagen in om de verschillende leerbehoeften van jongens en meisjes te vertalen in een kleinere prestatiekloof.

In dit hoofdstuk geven we allereerst een overzicht van de belangrijkste onderzoeksuitkomsten. Daarna bespreken we de consequenties van deze uitkomsten voor de dagelijkse onderwijspraktijk en -beleid. Tenslotte komen enkele tekortkomingen van het huidige onderzoek aan bod en geven we suggesties voor toekomstig onderzoek.

\subsection{Belangrijkste onderzoeksuitkomsten}

In dit rapport stonden drie onderzoeksvragen centraal: (1) Welke verschillen in neuropsychologische- c.q. hersenfuncties en hersenontwikkeling kunnen verschillen in studiesucces tussen jongens en meisjes in het mbo, hbo en wo verklaren? (2) Welke relatie bestaat er tussen in het mbo, hbo en wo veelvoorkomende leeromgevingen en het verschil in studiesucces tussen jongens en meisjes? En: (3) Zijn er verschillen tussen mbo-, hbo- en wo-instellingen in de mate waarin studiesucces tussen jongens en 
meisjes verschilt en wat kunnen we leren van 'good practices'? Op basis van de huidige onderzoeksbevindingen kunnen deze vragen als volgt worden beantwoord.

\subsubsection{Verschillen in neuropsychologische- c.q. hersenfuncties en hersenontwikkeling die het studiesucces tussen jongens en meisjes in het mbo, hbo en wo kunnen verklaren}

In hoofdstuk 3 werd aan de hand van een uitgebreide literatuurstudie onderzocht hoe neuropsychologische ontwikkeling en hersenrijping een verklaring kunnen bieden voor genderverschillen in studiesucces. Uit deze literatuurstudie bleek allereerst dat bij deze genderverschillen in prestaties in het hoger onderwijs sprake is van een belangrijke en intensieve interactie tussen biologische factoren (genen, hersenen en hormonen) en omgevingsfactoren (gezin, buurt, sociale en culturele factoren).

De overgang van de middelbare school naar het hoger onderwijs gaat niet alleen gepaard met een aantal ingrijpende omgevingsveranderingen (zoals een andere leefen leeromgeving en een andere studieaanpak) maar ook met een aantal biologische veranderingen. De adolescentie wordt gekenmerkt door een grote ontwikkeling in een aantal belangrijke neuropsychologische functies en vaardigheden. Het psychologisch en sociaal functioneren hangt daar direct mee samen. Juist in de late adolescentie (vanaf circa 17 jaar) zijn deze vaardigheden nog sterk in ontwikkeling. Ze hebben daarmee een sterke invloed op studieprestaties, leermotivatie, keuzegedrag en vaardigheden in plannen en prioriteren. De laatste jaren is er meer aandacht gekomen voor dergelijke vaardigheden; ze worden beschreven in termen van de zogenaamde 'non-cognitieve functies' (of, in het neuropsychologisch domein 'Executieve Functies'). Met name op het gebied van non-cognitieve functies als zelfinzicht en zelfregulatie, motivatie, doelgerichtheid, plannend vermogen, nieuwsgierigheid en initiatiefname maken jongeren nog tijdens de late adolescentie grote ontwikkelingen door. Uit onderzoek is herhaaldelijk gebleken dat studenten met minder goed ontwikkelde non-cognitieve functies slechter presteren in de studie dan studenten die het goed doen in non-cognitief functioneren. Onderzoek heeft tevens sterke aanwijzingen opgeleverd dat (de meeste van de) jongens gemiddeld 1-2 jaar in de neuropsychologische ontwikkeling achterlopen op (de meerderheid van de) meisjes. Dit geldt met name voor belangrijke non-cognitieve functies als zelfinzicht en zelfregulatie. Betoogd wordt dat subtiele verschillen in de neuropsychologische ontwikkeling een sterke invloed kunnen hebben op het vermogen - in de late adolescentie - tot zelfstandig leren, keuzegedrag, studieplanning maar ook voor het vormgeven van het eigen leven in bredere zin.

Echter, naast geslacht is de non-cognitieve ontwikkeling van jongeren ook sterk afhankelijk van (a) de persoonlijke levensgeschiedenis en opgedane ervaringen, (b) omstandigheden in gezin, familie en buurt, en (c) de aard van de steun, sturing, en inspiratie die de student van de leerkracht en de school krijgt. Dit maakt dat er niet alleen tussen jongens en meisjes, maar ook binnen beide geslachtsgroepen, sprake is van grote verschillen in non-cognitief functioneren. Ons onderzoek pleit voor ontwikkeling en uitvoering van interventies die zich op bovenstaande drie factoren toespitsen. Deze zouden moeten 
worden toegepast op zowel de jongens als de meisjes die zich in de late adolescentie op dit gebied aan het ontwikkelen zijn. Hierdoor zou er voor kunnen worden gezorgd dat zowel jongens als meisjes zich meer naar hun talenten kunnen ontwikkelen. In de overige vier deelstudies van dit rapport, hebben we ons vooral gericht op de invloed van interventies in de vorm van leeromgevingen in het mbo en ho op het studiesucces van jongens en meisjes. In de volgende twee paragrafen bespreken we de belangrijkste onderzoeksbevindingen van deze studies.

\subsubsection{De relatie tussen in het mbo, hbo en wo veelvoorkomende leeromgevingen en het verschil in studiesucces tussen jongens en meisjes}

Uit de literatuurstudie van hoofdstuk 3 kwam duidelijk naar voren dat jongens en meisjes neuropsychologisch sterk verschillen in de ontwikkeling van non-cognitieve functies. Daarnaast bleek uit zowel hoofdstuk 2 als 3 dat de leeromgeving en de daarmee samenhangende steun, sturing, en inspiratie die de student van de leerkracht en de school krijgt, van grote invloed is op de mate waarin cognitieve en non-cognitieve functies bepalend zijn voor het studieproces. Hieruit volgt dat het verschil in studiesucces tussen jongens en meisjes wellicht groter is in sommige leeromgevingen dan andere. In hoofdstuk 4 en 5 onderzochten we daarom in welke mate het studiesucces van jongens en meisjes in het mbo, hbo en het wo samenhangt met de leeromgeving van hun opleiding.

In hoofdstuk 4 gingen we allereerst na of en in hoeverre de invoering van een nieuwe leeromgeving in het mbo, namelijk het competentiegericht onderwijs (cgo), van invloed is geweest op de slaagkansen van jongens en meisjes. Het cgo wordt gekenmerkt door een vorm van onderwijs waarin het toekomstig uit te oefenen beroep leidend is voor de ontwikkeling van competenties. In het cgo is het onderwijs daarom niet alleen gericht op het bijbrengen van kennis, maar ook op vaardigheden die van belang zijn in het toekomstige beroep zoals zelfstandig werken, samenwerken en plannen. In deze vorm van onderwijs moet zodoende een sterker beroep worden gedaan op non-cognitieve functies als zelfinzicht en motivatie, doelgerichtheid, nieuwsgierigheid en initiatiefname. Het cgo staat daarmee in sterk contrast met het hiervoor in het mbo prevalerende vakonderwijs. In het klassieke vakonderwijs was het onderwijs opgebouwd rondom vakken en nam de docent een centrale rol in als informatiebron. Uit de resultaten van ons onderzoek bleek dat meisjes in nieuwe competentie gerichte leeromgeving een significant grotere kans dan jongens hebben om het mbo met een diploma te verlaten, terwijl dit verschil in de oude klassiek vakgerichte leeromgeving na controle van relevante kenmerken, niet zo was. Dat ondersteunt de hypothese dat meisjes door de competentiegerichte onderwijsvorm worden bevoordeeld door hun - op dat moment in de adolescentie - grotere vaardigheid in taalvaardigheden en door andere neuropsychologische verschillen tussen jongens en meisjes. Maar de conclusie kan slechts voorlopig zijn. Het is van belang verder na te gaan of dit in andere onderwijsrichtingen en andere uitkomstmaten ook geldt. 
In hoofdstuk 5 gingen we vervolgens na welke invloed de leeromgeving in het hbo en wo heeft op het genderverschil in twee verschillende aspecten van studiesucces: (1) het gemiddelde afstudeercijfer en (2) het competentieniveau van afgestudeerden 5 jaar na afstuderen. We maakten hierbij onderscheid tussen leeromgevingen die sterk varieerden in de mate waarin de docent de rol aannam als de belangrijkste informatiebron en de mate waarin er gebruik werd gemaakt van project-/probleemgestuurd onderwijs. Van een genderverschil in afstudeercijfers bleek allereerst enkel sprake te zijn binnen het hbo en niet binnen het wo. Meisjes behaalden in het hbo significant hogere afstudeercijfers dan jongens, althans in leeromgevingen waarin van de student een actieve rol verwacht werd en de docent geen centrale rol als belangrijkste informatiebron aannam. In leeromgevingen waarin de docent wel een centrale rol als belangrijkste informatiebron speelde, waren geen genderverschillen in afstudeercijfers zichtbaar. Tenslotte onderzochten we ook nog het effect van leeromgevingen op de academische vaardigheden van jongens en meisjes 5 jaar na afstuderen. In zowel het wo als het hbo bleek de leeromgeving hier niet van invloed op te zijn. Er bleek echter wel iets anders merkwaardigs aan de hand te zijn: hoewel meisjes tijdens de studie in het hbo of wo een grotere kans hadden dan jongens om het onderwijs met hogere examencijfers te verlaten, vertaalt zich dat niet in een hogere score op de eigen subjectieve inschatting van hun vaardigheden. Voor academische vaardigheden vonden we zelfs dat bij 3 van de 4 leeromgevingen meisjes in zelf-perceptie lager scoorden dan jongens. Voor een deel heeft dat er waarschijnlijk mee te maken dat het hier gaat om een zelfoordeel. We weten dat meisjes zichzelf vaker onderschatten dan jongens, en jongens zich juist vaker overschatten. Dat heeft te maken met de neuropsychologische ontwikkeling die hiervoor (paragraaf 8.1.1) is besproken. Maar ook als we daar rekening mee houden, bleven deze verschillen bestaan. Een andere oorzaak kan zijn dat meisjes na het verlaten van de opleiding een deel van hun voorsprong verliezen. Ook dit kan samenhangen met de subtiele verschillen in neuropsychologische ontwikkeling: aan het eind van de studie zijn jongens 'bij' en komen tot hetzelfde niveau als meisjes. Dat zou ook in lijn zijn met het feit dat we bij middelbaar en hoger opgeleiden helemaal geen sprake is van een voorspong van meisjes op kernvaardigheden (zie hierna). Maar alle gegevens uit ons onderzoek wijzen erop dat de betere studieprestaties van meisjes in het hoger onderwijs niets te maken heeft met hun cognitieve vaardigheden (al dan niet gemeten op basis van een test), maar veel meer met de non-cognitieve vaardigheden, zoals planning, nauwgezetheid en motivatie. Dit is een waardevol gegeven aangezien het suggereert dat interventies die zijn gericht op het ontwikkelen van deze vaardigheden een fors effect op leer-aanpak en studieprestatie zou kunnen hebben (zie 8.1.1)

In hoofdstuk 6 richtten we ons voorts op het vaardigheidsniveau van jongvolwassen mannen en vrouwen op het gebied van taal en rekenen in de late adolescentie. Zijn er genderverschillen in vaardigheidsniveau? En zo ja, hoe zijn deze genderverschillen in de afgelopen decennia geëvolueerd? Om dit te onderzoeken bestudeerden we de genderverschillen in cognitieve prestaties tussen jongvolwassenen uit verschillende geboortecohorten. Voor middelbaar- en hoogopgeleide mannen en vrouwen waren er geen opvallende verschuivingen in genderverschillen waarneembaar. Middelbaar- en 
hoogopgeleide vrouwen beschikten in alle cohorten over eenzelfde taalvaardigheid als mannen. In rekenvaardigheid waren de mannen daarentegen doorgaans iets beter dan vrouwen. Voor laagopgeleide jongvolwassenen waren er echter wel duidelijke genderverschillen in cognitieve vaardigheden in de verschillende cohorten zichtbaar. Dit kwam vooral doordat laagopgeleide vrouwen uit jongere cohorten het veel beter deden dan laagopgeleide vrouwen uit oudere cohorten, terwijl mannen geen of slechts een geringe stijging lieten zien. Een mogelijke verklaring hiervoor is dat de'vrouwvriendelijke' veranderingen in leeromgevingen die in de afgelopen jaren hebben plaatsgevonden een grotere impact hebben gehad op de cognitieve prestaties van laagopgeleide mannen en vrouwen dan op die van hun middelbaar-en hoogopgeleide equivalenten.

Samenvattend blijkt uit de onderzoeksresultaten dat leeromgevingen die gekenmerkt worden door een studentgerichte aanpak waarbij veel nadruk ligt op vaardigheden ${ }^{48}$ waarin meisjes qua neuropsychologische ontwikkeling en hersenrijping, een voorsprong hebben op jongens, in zowel het mbo als hbo, máár niet in het wo, een gunstiger effect hebben op het studiesucces van meisjes dan op dat van jongens. Hierdoor neemt de kloof in studiesucces toe. Echter, dit vertaalt zich niet direct in een hoger niveau van presteren na het afstuderen. Enkel voor laagopgeleide vrouwen constateren we een voorsprong op het gebied van cognitief presteren voor jongvolwassen vrouwen die afkomstig zijn uit jongere geboortecohorten waarvan de leeromgevingen doorgaans 'vrouwvriendelijker' van aard zijn.

TEKSTBOX 8.1 Laagopgeleide jongens: de grootste uitdaging?

Deze rapportage gaat expliciet over schoolprestatieverschillen in het mbo en ho. Uit onze analyses blijkt dat verschillen in gediplomeerde uitstroom uit het middelbaar beroepsonderwijs en hoger onderwijs hoogst waarschijnlijk niet worden gedreven door verschillen in de beheersing van kerncompetenties. Wel maken onze analyses duidelijk dat de achterstand in taalbeheersing en rekenvaardigheden onder de laagst opgeleide jongens het grootst is. Dat zou er op kunnen duiden dat laagst opgeleide jongens wellicht de minste mogelijkheden hebben om zich aan te passen aan voor hen ongunstige leeromgevingen, hetgeen het aanleren van kerncompetenties bemoeilijkt. Dat zou betekenen dat de laagst opgeleide jongens in toenemende mate achter zouden kunnen geraken, zowel ten opzichte van oudere jongens en mannen, als ten opzichte van tot hun eigen generatie behorende meisjes. Wij achten dit een urgent onderwerp voor verder onderzoek.

\subsubsection{Zijn er verschillen tussen mbo-, hbo- en wo-instellingen in de mate waarin studiesucces tussen jongens en meisjes verschilt en wat kunnen we leren van 'good practices'?}

In hoofdstuk 7 gingen we na hoe er binnen mbo-, hbo- en wo-instellingen doorgaans wordt omgegaan met het geconstateerde genderverschil in studiesucces. Hiertoe voerden we een elftal casestudies uit waarbij bestuurders, beleidsmakers en stafme-

48 Dit zijn o.a. vaardigheden als zelfinzicht, keuzegedrag, vaardigheden in plannen en prioriteren, verbale en sociale vaardigheden. 
dewerkers werden geïnterviewd over de aanpak van genderverschillen in studiesucces in hun instelling. Uit deze interviews kwam naar voren dat instellingen zich vaak wel bewust zijn van het bestaan van verschillen in studiesucces tussen jongens en meisjes, maar dat ze de oorzaken ervan niet goed erkennen en dat er maar zeer weinig instellingen bewust beleid voeren om de kloof te verkleinen. Een vergelijkbaar beeld komt naar voren in de analyse van buitenlandse praktijken. Europese landen verschillen in de mate waarin studiesucces in het hoger onderwijs prioriteit krijgt. In het algemeen is te stellen dat landen waar gelet wordt op doelmatigheid van hoger onderwijs, ook beleid op studiesucces is geformuleerd. De meeste buitenlandse experts hebben de indruk dat gender een gematigde invloed heeft op studiesucces. Dit suggereert dat dat op nationaal niveau verschillen in studiesucces niet als groot probleem wordt ervaren. Een logische consequentie is dan ook dat wij weinig buitenlandse praktijkvoorbeelden zijn tegengekomen die specifiek gericht zijn op studiesucces verschillen tussen jongens en meisjes. In de Nederlandse context lijken sommige instellingen generieke beleidsinstrumenten te verkiezen boven beleid dat specifiek gericht is op een sekse. De genderspecifieke beleidsinstrumenten zijn wij vooral tegenkomen bij opleidingen waar de studiesucces verschillen duidelijk aanwezig zijn, zoals bij de pabo's. Dit is indicatief voor de bevinding dat de verschillen in studiesucces nadrukkelijker gesignaleerd worden op niveaus die dichter bij de studenten staan. De ingezette gender-specifieke beleidsinstrumenten zijn vaak bij wijze van experiment ingevoerd. Terwijl het bij de generieke beleidsinstrumenten moelijker is om het effect op studiesucces verschillen te meten. Beide zorgen ervoor dat het lastig om de effectiviteit van de beleidswijziging te meten. Om deze reden zijn wij terughoudend geweest met het aanwijzen van 'good practices'. 
Van alle vertegenwoordigers van scholen en onderwijsinstellingen die wij in het kader van dit onderzoek spraken, was men bij het Deltion College het verst met het voeren en ontwikkelen van beleid dat rekening houdt met leerverschillen tussen jongens en meisjes. Kern van het beleid is, dat aan gender of sekse gerelateerde verschillen in leerstijlen en sociale interactie door docenten niet als problematisch hoeven te worden gezien. Er wordt uitdrukkelijk aan docenten gevraagd verschillen tussen jongens en meisjes te onderkennen, maar op een niet-normatieve wijze te benaderen. Veeleer wordt er naar gestreefd geobserveerde verschillen in gedrag waar nodig vanuit gender- of sekseperspectief te duiden en als zodanig te begrijpen, en deze inzichten te gebruiken om leerlingen persoonlijke begeleiding te kunnen bieden.

In de praktijk worden er regelmatig georganiseerde "inspiratiesessies" van een halfuur gehouden, waaraan docenten kunnen deelnemen en tijdens welke praktijkvoorbeelden worden bediscussieerd vanuit genderperspectief. Het doel is om docenten sensibel te maken voor verschillen tussen de seksen, en hen met elkaar te laten discussiëren over mogelijk vruchtbare en aan de eigen praktijk ontleende oplossingen. Aan docenten wordt gevraagd stereotyperingen in hun beoordeling van gedrag te vermijden, te accepteren dat er verschillen tussen jongens en meisjes zijn, en er zorg voor te dragen dat de leeromgeving zoveel mogelijk aansluit bij de verschillende eigenschappen van jongens en meisjes. Daar moeten - door de neutrale aanpak - uiteindelijk zowel jongens als meisjes wel bij varen.

De eerste effectmetingen moeten nog vervolledigd worden. Kwalitatieve observaties, variërend van gesprekken in docentenkamers waarin storend gedrag door jongens vanuit jongensperspectief wordt geduid, tot discussies tijdens overgangsvergaderingen waarin genderverschillen werden meegenomen in discussies over af- of uitstroom van leerlingen, op school doen alvast vermoeden dat het programma er in zou kunnen slagen de gewenste attitudeverandering bij leraren te bewerkstelligen.

\subsection{Aanbevelingen voor praktijk en beleid}

Op basis van dit onderzoek kunnen de volgende conclusies worden getrokken:

- meisjes hebben gemiddeld een voorsprong ten aanzien van jongens in de neuropsychologische ontwikkeling van een aantal belangrijke non-cognitieve functies (de meeste meisjes lopen in de late adolescentie hierin voor op de meeste jongens);

- non-cognitieve functies blijken een belangrijke voorspeller van studiesucces;

- zowel biologische factoren als sociaalpsychologische en culturele factoren hebben een invloed op de neuropsychologische rijping van adolescenten. Ze zijn daarmee een belangrijke bron van individuele verschillen tussen jongens en meisjes, maar ook binnen de afzonderlijke groepen van jongens en meisjes;

- het huidige mbo en ho wordt veelal gekenmerkt door studentgerichte leeromgevingen waarin een sterk beroep wordt gedaan op non-cognitieve functies; 
- zowel in het mbo als ho blijken studentgerichte leeromgevingen een gunstiger effect te hebben op het studiesucces van meisjes dan op dat van jongens, waardoor de verschillen in studiesucces vergroot worden;

- de voorsprong van vrouwen in studiesucces blijkt zich doorgaans niet te vertalen in betere kernvaardigheden (taal en rekenen) na het afstuderen;

- enkel voor laagopgeleide jongvolwassen geldt dat vrouwen een betere vaardigheid vertonen dan mannen in taalbeheersing en rekenvaardigheid;

- er wordt in het mbo en ho doorgaans weinig aandacht besteed aan beleid om de verschillen tussen jongens en meisjes in studiesucces te verkleinen.

Een en ander levert de volgende beleidsaanbevelingen op:

- Een eerste belangrijk punt van aandacht betreft de invloed van de leeromgeving op genderverschillen in studiesucces. Uit ons onderzoek komt duidelijk naar voren dat de recente ontwikkelingen naar meer studentgerichte leeromgevingen in het mbo en ho een positiever effect hebben op het studiesucces van meisjes dan het studiesucces van jongens. Dit komt doordat meisjes gemiddeld genomen een voorsprong hebben ten aanzien van jongens in de neuropsychologische en andere non-cognitieve vaardigheden die noodzakelijk zijn voor het succesvol opereren in een dergelijke leeromgeving, zoals zelfstandig werken, plannen en samenwerken. Hierdoor treedt een verschil in studiesucces op in de late adolescentie. Het is belangrijk te benadrukken dat hiermee niet is gezegd dat geobserveerde neuropsychologische verschillen betekenen dat aan prestatieverschillen tussen jongens en meisjes niet zo veel te doen is. Verschillen in hersenrijping verklaren immers ook een groot deel van de verschillen binnen de groepen jongens en meisjes, en er is een zekere overlap tussen de groepen. Deze overlap tussen de groepen hangt naast biologische factoren tevens samen met verschillen in de sociale context waarin men is opgegroeid, met eerder opgedane ervaringen (waaronder leerervaringen) en met vele culturele factoren. De analyses maken daarom juist aannemelijk dat het samenspel van hersenen en omgeving belangrijk is.

Onze bevindingen betekenen niet dat meer studentgerichte leeromgevingen afgeschaft zouden moeten worden. Deze zijn immers mede ontwikkeld in reactie op veranderingen in de economie, zoals technologische ontwikkelingen, flexibilisering, de veranderde organisatie van werk en globalisering die een impact hebben op de vraag naar bepaalde vaardigheden. Vaardigheden als sociale vaardigheden, zelfstandigheid en verantwoordelijkheid zijn van cruciaal belang voor het goed functioneren op de arbeidsmarkt van de $21^{\text {ste }}$ eeuw. Het is wel van groot belang dat in de huidige studentgerichte leeromgevingen extra aandacht moet worden geschonken aan studenten die nog in ontwikkeling zijn op gebied van hun non-cognitieve vaardigheden, zodat ook deze jongeren voldoende ruimte krijgen om zich naar hun talenten te kunnen ontwikkelen. Omdat er ook binnen beide geslachtsgroepen grote verschillen bestaan in non-cognitief functioneren, hoeft een succesvol beleid zich niet noodzakelijkerwijs expliciet te richten op verschillen tussen jongens en 
meisjes. Het volstaat om beleid toe te spitsen op leerlingen (ongeacht hun geslacht) van wie docenten observeren dat ze in deze belangrijke vaardigheden achterblijven. Het verkleinen van de prestatiekloof tussen jongens en meisjes zou een onbedoeld maar zeer gewenst neveneffect van zo'n algemeen beleid kunnen zijn.

Bij het maken van dergelijk beleid is een aantal zaken van belang:

$\checkmark$ Veel laat-adolescente jongeren hebben behoefte aan begeleiding van een docent of coach bij het plannen en zelfstandig maken van opdrachten. Zij zijn nog onvoldoende in staat om zelf voldoende structuur aan te brengen in hun werkwijze. In de huidige studentgerichte leeromgeving van het postsecundair en tertiair onderwijs wordt vaak van jongeren verwacht dat zij dit zelfstandig kunnen, maar onderzoek toont duidelijk aan dat de hersenen van veel jongeren hier nog onvoldoende rijp voor zijn. Veel eisen die in het huidige beroeps- en hoger onderwijs gesteld worden zijn dus voor veel jongeren wetenschappelijk gezien niet reëel.

$\checkmark$ De bevinding dat jongens bij hun entree in het beroeps- en hoger onderwijs in hun ontwikkeling van non-cognitieve vaardigheden achterlopen op meisjes, heeft ook gevolgen voor de wijze waarop toetsing en selectie plaatsvindt. Strenge toetsing en selectie in het begin van de studie zou ertoe kunnen leiden dat er relatief veel talent onder de jongens niet wordt benut dat bij een uitgestelde toetsing/selectie wel zou zijn benut. Of dit op grote schaal gebeurt, is op grond van publiek beschikbare gegevens nog niet te achterhalen, maar de invoering en aanscherping van selectie aan de poort en selectie in het eerste jaar (BSA) maakt dit vraagstuk maatschappelijk zeer relevant.

- Een tweede belangrijk punt van aandacht betreft tot slot de bewustwording van de oorzaken van genderverschillen in studiesucces bij directies, leerkrachten en beleidsmakers en de meervoudige bepaaldheid van deze verschillen. Uit ons onderzoek komt naar voren dat in instellingen voor mbo en ho weinig systematische kennis bestaat over de oorzaken van de prestatiekloof tussen jongens en meisjes. Beleid dat als doel zou hebben prestatiekloven in het onderwijs te verkleinen, zou daarom het beste kunnen beginnen met het creëren van een groter bewustzijn onder betrokkenen. Dit kan onder andere door middel van praktijkgerichte boeken, presentaties op congressen en brochures rondom dit thema die specifiek op de doelgroep van beleidsmakers en praktijkmensen zijn gericht. Pas wanneer er sprake is van een groter bewustzijn, zullen instellingen meer geneigd zijn maatregelen te treffen om genderverschillen in studiesucces weg te werken.

Een bijkomende beleidsaanbeveling luidt dan ook (toekomstige) docenten en schooldirecteuren beter op de hoogte moeten worden gebracht van de neurobiologische achtergrond van verschillen in jongens- en meisjesgedrag en het even grote belang van beide typen gedrag voor een succesvolle beroepscarrière in de 21e eeuw. Het is van groot belang dat docenten in hun onderwijs voldoende keuzemogelijkheden creëren, differentiëren en variëren zodat voldoende recht kunnen doen 
aan de verschillende leerbehoeften en interesses van verschillende typen leerlingen. Jongens hebben misschien vaker wat meer behoefte aan structuur en begeleiding en meisjes zijn gemiddeld genomen wat afwachtender. Maar er zijn ook meisjes die van competitie houden en jongens die graag zelfstandig een werkstuk maken. Essentieel is dat iedere leerling een leeromgeving krijgt aangeboden die recht doet aan zijn of haar specifieke noden.

\subsection{Beperkingen van het huidige onderzoek en suggesties voor vervolgonderzoek}

Dit rapport beoogt een helder, maar genuanceerd beeld te schetsen van verklaringen van genderverschillen in studiesucces in het Nederlandse mbo en ho, de rol van de neuropsychologische ontwikkeling en leeromgevingen daarin, alsook van mogelijke beleidsinterventies. Zoals bij elk onderzoek, kunnen er ook bij het voorliggend onderzoek een aantal kanttekeningen worden geplaatst. Allereerst stuitten we bij de uitvoering van het huidige onderzoek op de beperkingen in het huidige aanbod van data over de ontwikkeling in studiesucces van studenten in het mbo en ho. Zo bestaat er vooralsnog geen dataverzameling waarbij zowel de cognitieve als non-cognitieve vaardigheden van laatadolescente jongeren over een langere periode zijn gemeten. Een belangrijke vraag die daardoor vooralsnog onbeantwoord blijft is bijvoorbeeld rond welke leeftijd de kloof in studieprestaties en non-cognitieve functies het meest toeneemt. Ook is het tot dusverre nog onvoldoende duidelijk hoe de ontwikkeling in non-cognitieve vaardigheden exact gelinkt is aan de ontwikkeling in studieprestaties. Ten slotte hebben wij uit de aard van de rapportage en door beperkingen van de beschikbare gegevens maar naar een beperkt aantal indicatoren van studiesucces gekeken.

Het rapport mag dan ook zeker gelezen worden als een aanbeveling voor vervolgonderzoek. Daarbij is het ons inziens noodzakelijk inzichten uit meerdere wetenschapsgebieden in hun samenhang te begrijpen. Het rapport is een van de eerste pogingen om verschillende prestaties tussen jongens en meisjes vanuit een multidisciplinair oogpunt te benaderen. Deze aanpak maakt inzichtelijk dat studiesucces niet slechts begrepen kan worden door in te zoomen op individuen en hun eigenschappen, en dat het evenmin volstaat de onderzoeksaandacht uitsluitend te richten op contextuele omstandigheden, zoals leeromgevingen. Veeleer wordt duidelijk dat bij de verklaring van verschillen in schoolprestaties neuropsychologische, onderwijskundige, institutionele en sociale dimensies allen een rol van betekenis spelen. Bovendien zijn inzichten uit de verschillende vakgebieden complementair, en biedt de combinatie van theorieën een informatief inzicht in de verklaring van verschillen. Naar onze stellige overtuiging kunnen prestatieverschillen dan ook het meest vruchtbaar worden begrepen door theorieën en bevindingen uit de neuropsychologie, de sociologie, de onderwijskunde en de onderwijseconomie met elkaar te combineren. Onderzoeksgegevens zoals hier gepresenteerd geven richting aan mogelijke interventies in de onderwijspraktijk. Bij de ontwikkeling van een verdere onderzoeksagenda zou verder multidisciplinair onderzoek ons inziens daarom sterk tot aanbeveling strekken. 
Een belangrijke vraag die tot dusverre onbeantwoord is, is waarom het betere succes van meisjes in het onderwijs zich (nog) niet vertaalt in een beter succes op de arbeidsmarkt. $E r$ is hierbij sprake van een zekere paradox. Meisjes presteren in de afgelopen decennia veel beter in het onderwijs dan jongens, maar deze voorsprong vertaalt zich (nog) niet in een betere positie op de arbeidsmarkt. Het is onduidelijk waarom dit het geval is. Voor een deel komt dat omdat maar weinig studies verschenen zijn die de verschillen in de arbeidsmarktpositie systematisch hebben gekoppeld aan verschillen in de cognitieve prestaties op jongere leeftijd en hoe deze enerzijds het uiteindelijk bereikte opleidingsniveau bepalen en anderzijds de transitie naar de arbeidsmarkt. Een van de uitzonderingen betreft een ROA-studie van Büchner, Smits en Van der Velden (2012). Uit deze studie bleek dat de cognitieve prestaties op 12-jarige leeftijd een betere voorspeller waren voor het bereikte opleidingsniveau en - richting van jongens dan van meisjes. De auteurs vermoeden dat het bereikte niveau van meisjes waarschijnlijk meer wordt bepaald door niet-waargenomen non-cognitieve kenmerken, zoals doorzettingsvermogen of andere houdingskenmerken, maar dit vermoeden kon niet bevestigd worden door het ontbreken van directe informatie over deze non-cognitieve kenmerken. Uit de studie blijkt dat bij de transitie naar de arbeidsmarkt het succes bij meisjes sterker werd bepaald door de cognitieve verschillen op 12-jarige leeftijd, terwijl voor jongens dit effect vrijwel geheel verliep via het bereikte opleidingsniveau en -richting. Dit wijst erop dat de factoren die bepalend zijn voor het succes van meisjes in het onderwijs, niet dezelfde zijn als de factoren die bepalend zijn voor hun succes op de arbeidsmarkt. Voor jongens daarentegen lopen beide sets van factoren meer parallel. De ROA studie uit 2012 maakte gebruik van het zogeheten SLVO-bestand, een longitudinaal onderzoek van het CBS waarbij 16.800 leerlingen die in 1982 het voortgezet onderwijs zijn ingestroomd verder zijn gevolgd in hun schoolloopbaan. Deze data zijn gekoppeld aan de registerbestanden van het CBS uit 2005 om de arbeidsmarktpositie op 35-jarige leeftijd vast te stellen. Inmiddels zijn vergelijkbare data uit recentere cohorten beschikbaar waarbij ook directe informatie over de non-cognitieve vaardigheden is gemeten. We pleiten ervoor om een aanvullend onderzoek te verrichten naar de vraag of de eerder geconstateerde verschillen tussen jongens en meisjes in het verband tussen cognitieve kenmerken en bereikt onderwijsniveau, onderwijsrichting en bereikte arbeidsmarktpositie ook gevonden worden bij recentere cohorten en of het hogere onderwijssucces van meisjes inderdaad verklaard wordt door de non-cognitieve kenmerken. 


\section{REFERENTIES}

Aamodt, P.O., Hovdhaugen, \& E., Opheim, V. (2009). Effects of a national education reform on the academic progress of students. Journal of Adult \& Continuing Education, 15(2), 220 -234 .

Albert, D., \& Steinberg, L. (2011). Judgment and decision making in adolescence. Journal of Research on Adolescence, 21(1), 211-224.

Alst,J.V.(2010).Zichtop sekseverschillen in studiesucces. Een verkenning metaanbevelingen voor de Radboud Universiteit.

Archer,J. (2004). Sex differences in aggression in real-world settings: a meta-analytic review. Review of general Psychology, 8(4), 291.

Arnett, J. J. (2000). Emerging Adulthood, A Theory of Development From the Late TeensThrough the Twenties. American Psychologist, 55(5), 469-480.

Arnold, I.J.M. (2014). The effectiveness of academic dismissal policies in Dutch university education: an empirical investigation. Studies in Higher Education, 1-17.

Auduc, J. L. (2009). Sauvons les garçons!. Descartes \& cie.

Baars, M.A.E., Nije Bijvank, M., Tonnaer, G., \& Jolles, J. (2015). Self-report measures of Executive Functioning are a determinant of academic performance in first-year students at a university of applied sciences. Frontiers in Educational Psychology, in print.

Bean, J. P., \& Vesper, N. (1992, October). Student dependency theory: An explanation of student retention in college. In annual meeting of the Association for the Study of Higher Education, Minneapolis, $M N$.

Beltz,A.M.,\&Berenbaum,S.A.(2013).Cognitiveeffectsofvariationsin pubertaltiming:Ispuberty a period of brain organization for human sex-typed cognition?. Hormones and behavior, 63(5), 823-828.

Berkhout, E. (2014). Waardering van baankenmerken, vrouw-man verschillen in niet-geldelijke baankenmerken en salaris. Amsterdam: SEO economisch onderzoek.

Best,J.R.,Miller,P.H., \&Naglieri,J.A. (2011). Relationsbetween executivefunction andacademic achievement from ages 5 to 17 in a large, representative national sample. Learning and individual differences, 21(4), 327-336.

Bourdieu,P.(1986). Theforms of capital.InJ.G.Richardson(Ed.), Handbookof TheoryandResearch for the Sociology of Education (pp. 241-258). Greenwood Publishing Group.

Brooks-Gunn, J., \& Petersen, A.C. (1984). Problems in studying and defining pubertal events. Journal of Youth and Adolescence, 13(3), 191-196. 
Brooks-Gunn, J., Klebanov, P. K., \& Liaw. F. (1995). The Learning, Physical, and Emotional Environment of the Home in the Context of Poverty: The Infant Health and Development Program. Children and Youth Services Review, 17(1-2), 251-276.

Buchmann, C., DiPrete, T. \& McDaniel, A. (2008).Gender inequalities in education. Annual Review of Sociology, 34, 319-337.

Büchner, C., Smits, W., \& Velden, R. K. W. (2012). Education, cognitive skills and earnings of males and females. ROA, Maastricht University School of Business and Economics.

Buisman, M., Allen, J. P., Fouarge, D., Houtkoop, W., \& Velden, V. D. R. (2013). PIAAC: Kernvaardigheden voor Werk en Leven. Resultaten van de Nederlandse survey 2012. None $(E N)$.

Buss, D. M., \& Schmitt, D. P. (1993). Sexual strategies theory: an evolutionary perspective on human mating. Psychological review, 100(2), 204.

Bussey, K., \& Bandura, A. (1999). Social cognitive theory of gender development and differentiation. Psychological Review, 106, 676-713.

Casey, B. J., Jones, R. M., \& Somerville, L. H. (2011). Braking and accelerating of the adolescent brain. Journal of Research on Adolescence, 21(1), 21-33.

Casey, B. J., Duhoux, S., \& Cohen, M. M. (2010). Adolescence: what do transmission, transition, and translation have to do with it?. Neuron, 67(5), 749-760.

CBS. (2014). Aansluiting vanuit het onderwijs op de arbeidsmarkt van jongens en meisjes met een diploma gehaald op het mbo bol-voltijd of ho voltijd. Notitie. Juli 2014.

CBS. (2015). Hoger onderwijs; eerstejaarsstudenten naar studierichting en vooropleiding. Retrieved 17-09-2015

Ceci, S. J., Williams, W. M., \& Barnett, S. M. (2009). Women's underrepresentation in science: sociocultural and biological considerations. Psychological bulletin, 135(2), 218.

Chaplin, T. M., \& Aldao, A. (2013). Gender differences in emotion expression in children: a meta-analytic review. Psychological Bulletin, 139, 735-65

Christakou, A., Brammer, M., \& Rubia, K. (2011). Maturation of corticostriatal activation and connectivity associated with developmental changes in temporal discounting. Neuroimage, 54, 1344-1354.

Claessen, J. (2013), Meisjessucces of jongensprobleem? De groeiende achterstand van jongens in het onderwijs ofwel de voorsprong van meisjes. Heerlen: LOOK - Open Universiteit.

Coenen, J., Meng, C., \& Velden, R. van der (2011). Schoolsucces van jongens en meisjes in het HAVO en VWO: waarom meisjes het beter doen. ROA Report 002, Maastricht University, Research Centre for Education and the Labour Market (ROA).

Costa Jr, P., Terracciano, A., \& McCrae, R. R. (2001). Gender differences in personality traits across cultures: robust and surprising findings. Journal of personality and social psycholo$g y, 81(2), 322$.

Cotton, D. R. E., Joyner, M., George, R., \& Cotton, P. A. (2015). Understanding the gender and ethnicity attainment gap in UK higher education.Innovations in Education and Teaching International, (ahead-of-print), 1-12.

Crone, E. A., \& Dahl, R. E. (2012). Understanding adolescence as a period of social-affective engagement and goal flexibility. Nature Reviews Neuroscience, 13(9), 636-650.

Cross, C. P., Cyrenne, D. L. M., \& Brown, G. R. (2013). Sex differences in sensation-seeking: a meta-analysis. Scientific reports, 3 . 
Dahl, R. E. (2004). Adolescent brain development: a period of vulnerabilities and opportunities. Keynote address. Annals of the New York Academy of Sciences, 1021(1), 1-22.

Delegation for Gender Equality in Higher Education (2014). Jämställdhet $i$ högskolan - ska den nu ordnas en gång för alla? [Equality in higher education - once and for all?] (in Swedish)

Department for Business, Innovation and Skills (2014). National strategy for access and student success in higher education.

Dewey, J. (1916). Democracy and education. The Free Press, New York.

Diamond, A. (2013). Executive functions. Annual review of psychology, 64, 135.

Diekman, A. B., Clark, E. K., Johnston, A. M., Brown, E. R., \& Steinberg, M. (2011). Malleability in communal goals and beliefs influences attraction to stem careers: evidence for a goal congruity perspective. Journal of personality and social psychology, 101(5), 902.

DiPrete, T. A., \& Buchmann, C. (2006). Gender-specific trends in the value of education and the emerging gender gap in college completion. Demography, 43(1), 1-24.

Driessen, G., \& Doesborgh, J. (2004). De feminisering van het basisonderwijs. Effecten van het geslacht van de leerkrachten op de prestaties, de houding en het gedrag van de leerlingen.

Driessen, G., \& Langen, A. V. (2011). Mogelijke verklaringen voor onderwijsachterstanden van jongens. Pedagogiek, 31(2), 155-171.

Duckworth, A. L., \& Seligman, M. E. P. (2006). Self-Discipline Gives Girls the Edge: Gender in Self-Discipline, Grades, and Achievement Scores. Journal of Educational Psychology, 98, 198-208.

Eagly, A. H. (2009). The his and hers of prosocial behavior: an examination of the social psychology of gender. American Psychologist, 64(8), 644.

Eagly, A. H., \& Crowley, M. (1986). Gender and helping behavior: A meta-analytic review of the social psychological literature. Psychological bulletin,100(3), 283.

Eagly, A. H., \& Wood, W. (1999). The origins of sex differences in human behavior: Evolved dispositions versus social roles. American psychologist, 54(6), 408.

Eccles, J. S. (2005). Studying gender and ethnic differences in participation in math, physical science, and information technology. New Directions for Child and Adolescent Development, 2005(110), 7-14.

Elffers, L. (2011). The transition to post-secondary vocational education: students' entrance, experiences, and attainment. ICO.

Else-Quest, N. M., Hyde, J. S., \& Linn, M. C. (2010). Cross-national patterns of gender differences in mathematics: a meta-analysis. Psychological bulletin,136(1), 103.

Else-Quest, N. M. (2012). Gender differences in temperament. Handbook of temperament, 479-496.

Else-Quest, N. M., Hyde, J. S., Goldsmith, H. H., \& Van Hulle, C. A. (2006). Gender differences in temperament: a meta-analysis. Psychological bulletin,132(1), 33.

Engbers, S. (2012). Interview met Jelle Jolles: 'Waar blijven Paul en Ahmed?' Meisjes streven jongens voorbij in het hoger (medisch) onderwijs. I.O. Magazine van het IOO, het blad voor Onderwijs en Opleiden van het VU Medisch Centrum, Amsterdam p. 8-12

Entwisle, D., Alexander, K., \& Olson, L. (2007). Early schooling: The handicap of being poor and male. Sociology of Education, 80, 114-138.

Evers, F., Livernois, J., \& Mancuso, M. (2006). Where are the boys? Gender imbalance in higher education. Higher Education Management and Policy, 18(2), 1-13. 
Feingold, A. (1994). Gender differences in personality: a meta-analysis.Psychological bulletin, 116(3), 429.

Fraser, B. J. (1982). Assessment of Learning Environments: Manual for Learning Environment Inventory (LEI) and My Class Inventory (MCI). Third Version.

Fredricks, J. A., Blumenfeld, P. C., \& Paris, A. H. (2004). School engagement: Potential of the concept, state of the evidence. Review of educational research, 74(1), 59-109.

Geerdink, G. (2010). Studierendement en sekseverschillen. In Congresbundel Hanovatie themadag 2010. Arnhem: Hogeschool van Arnhem en Nijmegen. pp 13-26.

Gied, J.N., Rapoport, J.L. (2010). Structural MRI of pediatric brain development: what have we learned and where are we going? Neuron 67, pp 728-734.

Gogtay, N., Giedd, J. N., Lusk, L., Hayashi, K. M., Greenstein, D., Vaituzis, A. C., ... \& Thompson, P. M. (2004). Dynamic mapping of human cortical development during childhood through early adulthood. Proceedings of the National Academy of Sciences of the United States of America, 101(21), 8174-8179.

Haemmerlie Montgomery, F. en Montgomery, R. L. (2012). Gender differences in the academic performance and retention of undergraduate engineering majors. College Student Journal, 46(1), 40-45.

Halpern, D. F. (2013). Sex differences in cognitive abilities. Psychology press.

HAN (2012). Instellingsplan 2012-2016: Kennis in Interactie.

Hanushek, E. A., \& Woessmann, L. (2012). Do better schools lead to more growth? Cognitive skills, economic outcomes, and causation. Journal of Economic Growth, 17(4), 267-321.

Harris, J., Hirsh-Pasek, K., \& Newcombe, N. S. (2013). Understanding spatial transformations: similarities and differences between mental rotation and mental folding. Cognitive processing, 14(2), 105-115.

Hartley, B. L., \& Sutton, R. M. (2013). A stereotype threat account of boys' academic underachievement. Child development, 84(5), 1716-1733.

Hedges, L. V., \& Nowell, A. (1995). Sex differences in mental testscores, variability, and numbers of high-scoring individuals. Science, 269(5220), 41-45.

HEFCE (2013). Trends in young participation in higher education. October 2013/28

Heil, M., Kavšek, M., Rolke, B., Beste, C., \&Jansen, P. (2011). Mental rotation in female fraternal twins: Evidence for intra-uterine hormone transfer?.Biological psychology, 86(1), 90-93.

Herweijer, L. (2008). Gestruikeld voor de start, De school verlaten zonder startkwalificatie. DenHaag: Sociaal en Cultureel Planbureau.

Heublein, U., Spangenberg, H., \& Sommer, D. (2003). Ursachen des Studienabbruchs. Analyse 2002. Hannover: HIS, Hochschul-Informations-System.

Humburg, M., \& van der Velden, R. (2015). Self-assessments or tests? Comparing cross-national differences in patterns and outcomes of graduates' skills based on international largescale surveys. Studies in Higher Education, $40(3)$.

Hyde, J. S. (2005). The gender similarities hypothesis. American psychologist,60(6), 581.

Hyde, J. S., \& Linn, M. C. (1988). Gender differences in verbal ability: A meta-analysis. Psychological bulletin, 104(1), 53.

Hyde, J. S., Mezulis, A. H., \& Abramson, L. Y. (2008). The ABCs of depression: integrating affective, biological, and cognitive models to explain the emergence of the gender difference in depression. Psychological review,115(2), 291. 
Hyde, J. S., \& Mertz, J. E. (2009). Gender, culture, and mathematics performance. Proceedings of the National Academy of Sciences, 106(22), 8801-8807.

Hyde, J. S. (2014). Gender similarities and differences. Annual review of psychology, 65, 373398.

Hyde, J. S., Lindberg, S. M., Linn, M. C., Ellis, A. B., \& Williams, C. C. (2008). Gender similarities characterize math performance. Science, 321(5888), 494-495.

Jackson, C. en Dempster, S. (2009). 'I sat back on my computer ... with a bottle of wiskey next to me': constructing 'cool' masculinity through 'effortless' achievement in secondary and higher education. Journal of Gender Studies, 18(4), 341-356.

Jackson, C., Dempster, S. en Pollard, L. (2015). “They just don't seem to really care, they just think it's cool to sit there and talk": laddism in university teaching-learning contexts. Educational Review, 67(3), 300-314.

Jacob, B. A. (2002). Where the boys aren't: Non-cognitive skills, returns to school and the gender gap in higher education. Economics of Education review, 21(6), 589-598.

Jacobs, J. A. (1996). Gender inequality and higher education. Annual Review of Sociology, 153185.

Jarman, J., Blackburn, R. M., \& Racko, G. (2012). The dimensions of occupational gender segregation in industrial countries. Sociology, 46(6), 1003-1019.

James, A. N. (2007). Teaching the male brain: how boys think, feel, and learn in school. Thousand Oaks, Calif.: Corwin.

Jaušovec, N., \& Jaušovec, K. (2012). Sex differences in mental rotation and cortical activation patterns: Can training change them?. Intelligence, 40(2), 151-162.

Jolles, J. (2011). Ellis en het verbreinen. Over hersenen, gedrag en educatie, 176.

Jolles, J. (2014). Voor sommige studenten staan de stoplichten van de ontplooiing op groen'. In: Dit wil je weten. Maven Publ, ISBN 9789491845352, pp 23-25.

Jolles, J. (2007). Neurocognitieve ontwikkeling en adolescentie: enkele implicaties voor het onderwijs. Onderwijsinnovatie, maart 2007, 30-32.

Jolles, J. (2009). Brein, leren en onderwijsontwikkeling in het HBO. Keynote jaaropening Hogeschool Inholland, 3 september 2009. Haarlem.

Jolles, J. (2015). Onderwijs, hersenen en cognitie: de kloof overbrugd? Didactief Online, webartikel 31 aug 2015: http://files.jellejolles.nl/150831JollesDidactiefOnlineDf.pdf

Jorgensen, C. H. (2015). "Some boys' problems in education; what is the role of VET?" Journal of Vocational Education \& Training, 67(1), 62-77.

Jorgensen, S., Ferraro, V., Fichten, C., \& Havel, A. (2009). Predicting College Retention and Dropout: Sex and Disability. Online Submission.

Kenniscentrum Beroepsonderwijs Arbeidsmarkt (2014). Benchmark middelbaar beroepsonderwijs 2013, bouwsteen studiesucces. Nijmegen.

Kennisnet (2013). Big data, van hype naar actie. Op zoek naar waardevolle inzichten voor het vergroten van studiesucces. Zoetermeer.

Kessler, R. C., McGonagle, K. A., Swartz, M., Blazer, D. G., \& Nelson, C. B. (1993). Sex and depression in the National Comorbidity Survey I: Lifetime prevalence, chronicity and recurrence. Journal of affective disorders, 29(2), 85-96.

Kimura, D. (2002). Sex differences in the brain. Scientific American, 12, 32-37.

Kling, K. C., Hyde, J. S., Showers, C. J., \& Buswell, B. N. (1999). Gender differences in self- 
esteem: a meta-analysis. Psychological bulletin, 125(4), 470.

Knouse, L. E., Feldman, G., \& Blevins, E. J. (2014). Executive functioning difficulties as predictors of academic performance: examining the role of grade goals. Learning and Individual Differences, 36, 19-26.

Kok, H. (2012). Promotieonderzoek Herman Kok: “wat maakt een leeromgeving succesvol?”. http://www.schoolfacilities.nl/inrichting/inrichtingsconcepten/3288-promotieonderzoekherman-kok-wat-maakt-een-leeromgeving-succesvol

Kolb, D. A. (1984). Experiential learning: experiences as the source of learning and development. Englewoords Cliffs, NJ: Prentice-Hall.

Koning, B. de \& Loyens, S. (2011). Generation Psy, studentfactoren en studiesucces. Risbo Research. Den Haag: Ministerie van Onderwijs, Cultuur en Wetenschap.

Kottmann, A., \& Kaiser, F. (2013). Literature review, Wast age and completion rates, Rapport voor de Inspectie van het Onderwijs. Enschede: CHEPS.

Krendl, A. C., Richeson, J. A., Kelley, W. M., \& Heatherton, T. F. (2008). The Negative Consequences of Threat A Functional Magnetic Resonance Imaging Investigation of the Neural Mechanisms Underlying Women's Underperformance in Math. Psychological Science, 19(2), 168-175.

Krupp, D. B., Kim, J., Taylor, P., \& Barclay, P. (2014). Cooperation and competition in large classrooms. Toronto: Higher Education Quality Council of Ontario.

Kuh, G. D., Kinzie, J., Buckley, J. A., Bridges, B. K., \& Hayek, J. C. (2006). What matters to student success: A review of the literature commissioned report for the national symposium on postsecondary student success: Spearheading a dialog on student success. Washington, DC: National Postsecondary Education Cooperative.

Kuipers, N. (2014). Aansluiting vanuit het onderwijs op de arbeidsmarkt van jongens en meisjes met een diploma gehaald op het mbo bol-voltijd of ho voltijd.Den Haag/Heerlen: CBS.

Kyriakides, L., \& Creemers, B. (2011). Can Schools Achieve Both Quality and Equity? Investigating the Two Dimensions of Educational Effectiveness. Journal of Education for StudentsPlaced at Risk, 16, 237-254.

Langen, A. M. L., \& Driessen, G. W. J. M. (2006). Sekseverschillen in onderwijsloopbanen: een internationaal comparatieve trendstudie. ITS.

Lassibille, G., \& Navarro Gómez, L. (2008). Why do higher education students drop out? Evidence from Spain. Education Economics, 16(1), 89-105.

Leaper, C., \& Robnett, R. D. (2011). Women are more likely than men to use tentative language, aren't they? A meta-analysis testing for gender differences and moderators. Psychology of Women Quarterly, 35(1), 129-142.

Leathwood, C. (2006). Gender, equity and the discourse of the independent learner in higher education. Higher Education, 52(4), 611-633.

Lee, N. C., de Groot, R. H., Boschloo, A., Dekker, S., Krabbendam, L., \& Jolles, J. (2013). Age and educational track influence adolescent discounting of delayed rewards. Frontiers in psychology, 4 .

Legewie, J., \& DiPrete, T. A. (2012). School context and the gender gap in educational achievement. American Sociological Review, 77(3), 463-485.

Lenroot, R. K., \& Giedd, J. N. (2010). Sex differences in the adolescent brain.Brain and cognition, 72(1), 46-55. 
Levels, M., \& Velden, R. van der (forthcoming), Nothing but a number? Explaining variation of age-related differences in key information-processing skills, accepted for publication in proceedings of the ETS/OECD PIAAC Invitational Conference "The importance of skills and how to assess them”, 13-15 November, Washington. BocaRaton: CRC Press, Taylor, Francis Group.

Levine, S. C., Vasilyeva, M., Lourenco, S. F., Newcombe, N. S., \& Huttenlocher, J. (2005). Socioeconomic status modifies the sex difference in spatial skill. Psychological Science, 16(11), 841-845.

Lightdale, J. R., \& Prentice, D. A. (1994). Rethinking sex differences in aggression: Aggressive behavior in the absence of social roles. Personality and Social Psychology Bulletin, 20(1), $34-44$.

Linn, M. C., \& Petersen, A. C. (1985). Emergence and characterization of sex differences in spatial ability: A meta-analysis. Child development, 1479-1498.

Lowe, H., \& Cook, A. (2003). Mind the Gap: are students prepared for higher education?. Journal of further and higher education, 27(1), 53-76.

Luken, T. (2008). De (on)mogelijkheid van nieuw leren en zelfsturing. In M. Kuypers \& F.

Meijers (red.), Loopbaanleren: Onderzoek en praktijk in het onderwijs (pp. 127-151). Antwerpen/Apeldoorn: Garant.

Mael, F., Alonso, A., Gibson, D., Rogers, K., \& Smith, M. (2005). Single-Sex Versus Coeducational Schooling: A Systematic Review. Doc\# 2005-01. US Department of Education.

Maréchal - van Dijken, J., Loor, O., Sanders, M., \& Vliegenthart, M. (2012)' Jongens... aan de slag!' APS.

Martino, W. (2008). Boys'Underachievement: Which Boys are We Talking About?. Ontario, Literacy and Numeracy Secretariat.

Mastekaasa, A., \& Smeby, J. C. (2008). Educational choice and persistence in male-and femaledominated fields. Higher Education, 55(2), 189-202.

May, A. (2011). Experience-dependent structural plasticity in the adult human brain. Trends in cognitive sciences, 15(10), 475-482.

McCrae, R. R., \& Costa Jr, P. T. (2013). Introduction to the empirical and theoretical status of the five-factor model of personality traits.

Meeuwisse, M., Born, M. P., \& Severiens, S. E. (2013). Academic performance differences among ethnic groups: do the daily use and management of time offer explanations? SocialPsychology of Education, 16(4), 599-615.

Meeuwisse, M., Severiens, S. E., \& Born, M. P. (2010). Learning environment, interaction, sense of belonging and study success in ethnically diverse student groups. Research in $\mathrm{Hi}$ gher Education, 51(6), 528-545.

Meeuwisse, M., Severiens, S. E., \& Born, M. P. (2010b). Reasons for withdrawal from higher vocational education. A comparison of ethnic minority and majority non-completers. Studies in Higher Education, 35(1), 93-111.

Meeuwisse, M., Wensveen, P. v., \& Severiens, S. (2011). Tijd om te studeren: een onderzoek naar tijdbesteding en studiesucces. In S. Severiens (Ed.), Studiesucces in de bachelor (Vol.138). Den Haag: Ministerie van Onderwijs, Cultuur en Wetenschap.

Meijden, A. van der, Westerhuis, A., Huisman, J., Neuvel, J. \& Groenenberg, R., (2009). Beroepsonderwijs in verandering: op weg naar competentiegericht onderwijs. De vierde 
meting van de cgo-monitor. 's-Hertogenbosch/Amsterdam: Expertisecentrum Beroepsonderwijs

Meijden, A. van der, Westerhuis, A., Huisman, J., Neuvel, J., \& Groenenberg, R. (2010).Cgo langs de meetlat. 's-Hertogenbosch/Amsterdam: Expertisecentrum Beroepsonderwijs.

Meijden, A., Berg, J. van der., \& Román, A. (2013). Het mbo tijdens invoering cgo. 's-Hertogenbosch: Expertisecentrum Beroepsonderwijs.

Meijden, A. van der, Berg, J.van der \& Román, A. (2013). Ontwerp en resultaat van opleidingen in het middelbaar beroepsonderwijs. De vijfde meting van de cgo-monitor. 's-Hertogenbosch: Expertisecentrum Beroepsonderwijs.

Meijden, A. van der \& Petit, R., (2014) Evaluatie kwalificatiedossiers Mbo. Analyse op bestaande databronnen. Ervaringen van betrokkenen. 's-Hertogenbosch: Expertisecentrum Beroepsonderwijs.

Meng, C. (2006).Discipline-Specific or Academic? Acquisition, Role and Value of Higher Education Competencies. (dissertation).Maastricht: Maastricht University.

Mickelson, R. A. (1989). Why does Jane read and write so well? The anomaly of women's achievement. Sociology of Education, 47-63.

Miller, D.I., \& Halpern, D.F. (2014). The new science of cognitive sex differences. Trends in Cognitive Sciences, 18(1), 37-45.

Ministerie van Onderwijs Cultuur en Wetenschappen. (1998). Een kristal van kansen, Emancipatienota 1998-2002.

Miyake, A., Kost-Smith, L. E., Finkelstein, N. D., Pollock, S. J., Cohen, G. L., \& Ito, T. A. (2010). Reducing the gender achievement gap in college science: A classroom study of values affirmation. Science, 330(6008), 1234-1237.

Moore,D.S., \&Johnson,S.P.(2011).MentalRotationofDynamic, Three-DimensionalStimuliby3Month-Old Infants. Infancy, 16(4), 435-445.

Nelissen, T. C. C., \& F. A. van der Boon (2014). Predicting student succes in Dutch higher education. EAIR 36th annual forum. Essen: 23.

Ochsenfeld, F. (2014). Why Do Women's Fields of Study Pay Less? A Test of Devaluation, Human Capital, and Gender Role Theory. European Sociological Review, jcu060.

OCW (2014), Geslacht als factor van succes (Factsheet).

OECD (2008). Higher education to 2030. Volume I: Demography. Paris, OECD.

OECD (2009). Equally prepared for life? How 15-year-old boys and girls perform in school. Paris, OECD.

OECD (2015a). Fostering and Measuring Skills: Improving Cognitive and Non-Cognitive Skills to Promote Lifetime Success. Paris, OECD.

OECD (2015b). The ABC of Gender Equality in Education. Aptidude, behaviour, confidence. Paris, OECD.

Olsen, O. J., Host, H., \& Tonder, A. H. (2014). The current state of key challenges for Norwegian VET.

Onderwijsinspectie (2014). Kwaliteit kleine MBO-opleidingen. Utrecht.

Pahlke, E., Hyde, J.S., \& Mertz, J.E. (2013). The effects of single-sex compared with coeducational schooling on mathematics and science achievement: Data from Korea. Journal of Educational Psychology, 105(2), 444.

Penner, A. M., \& Paret, M. (2008). Gender differences in mathematics achievement: Exploring the 
early grades and the extremes. Social Science Research, 37(1), 239-253.

Petersen, J. L., \& Hyde, J. S. (2010). A meta-analytic review of research on gender differences in sexuality, 1993-2007. Psychological bulletin, 136(1), 21.

Philbin, M., Meier, E., Huffman, S., \& Boverie, P. (1995). Asurvey ofgender andlearningstyles. Sex Roles, 32(7-8), 485-494.

Platform Beleidsinformatie (2014). Factsheet: Geslacht als factor van succes?

Quinn, P. C., \& Liben, L. S. (2014). A sex difference in mental rotation in infants: convergent evidence. Infancy, 19(1), 103-116.

Rabe-Hesketh, S., \& Skrondal, A. (2008). Multilevel and longitudinal modeling using Stata. STATA press.

Raznahan, A., Lee, Y., Stidd, R., Long, R., Greenstein, D., Clasen, L., ... \& Giedd, J. N. (2010). Longitudinally mapping the influence of sex and androgen signaling on the dynamics of human cortical maturation in adolescence.Proceedings of the National Academy of Sciences, 107(39), 16988-16993.

Reints, A. (2013). Leerstijlkenmerken van digitale leermiddelen en het effect op de leerprestaties van jongens en meisjes. Utrecht, Expertisecentrum leermiddelenontwikkeling.

Reilly, D. (2012). Gender, culture, and sex-typed cognitive abilities. PloS one, 7(7), e39904.

Rindermann, H. en Baumeister, A.E.E. (2015). Parents' SES vs. parental educational behavior and children's development: A reanalysis of the Hart and Risley study. Learning and Individual Differences, 37,133-138.

Robinson, J. P., \& Lubienski, S. T. (2011). The Development of Gender Achievement Gaps in Mathematics and Reading During Elementary and Middle School Examining Direct Cognitive Assessments and Teacher Ratings.American Educational Research Journal, 48(2), 268-302.

Robst, J., Keil, J., \& Russo, D. (1998). The effect of gender composition of faculty on student retention. Economics of Education Review, 17(4), 429-239.

Schaacke, J. (2014), Onderwijsongelijkheid tussen jongens en meisjes, Ministerie van OCW:DUO.

Schmader, T. (2010). Stereotype threat deconstructed. Current Directions in Psychological Science, 19(1), 14-18.

Schulz, K. M., Molenda-Figueira, H. A., \& Sisk, C. L. (2009). Back to the future: the organizational-activational hypothesis adapted to puberty and adolescence. Hormones and behavior, 55(5), 597-604.

Severiens, S., \& Ten Dam, G. (2012). Leaving college: A gender comparison in male and female -dominated programs. Research in Higher Education, 53(4), 453-470.

Severiens, S., Meeuwisse, M., \& Born, M. (2014). Student experience and academic success: comparing a student-centred and a lecture-based course programme. Higher Education, 117.

Severiens, S. E., \& Schmidt, H. G. (2009). Academic and social integration and study progress in problem based learning. Higher Education, 58(1), 59-69.

Shaw, P., Kabani, N. J., Lerch, J. P., Eckstrand, K., Lenroot, R., Gogtay, N., ... \& Wise, S. P. (2008). Neurodevelopmental trajectories of the human cerebral cortex. The Journal of Neuroscience, 28(14), 3586-3594.

Simon, H. A. (1965). Administrative behavior (Vol. 4). New York: Free Press.

Snijders, T.A.B \& Bosker, RJ. (2012) Multilevel Analysis: An Introduction to Basic and Advanced 
Multilevel Modeling, second edition. London: Sage Publishers.

Sonnert, G., \& Fox, M. F. (2012). "Women, men, and academic performance in science and engineering: the gender difference in undergraduate gade point averages." The Journal of Higher Education, 83(1), 73-101.

Spencer, S. J., Steele, C. M. en Quinn, D. M. (1999). Stereotype threat and women's math performance. Journal of Experimental Social Psychology, 35(1), 4-28.

Su, R., Rounds, J., \& Armstrong, P. I. (2009). Men and things, women and people: a metaanalysis of sex differences in interests. Psychological bulletin, 135(6), 859.

Steinberg, L., \& Morris, A. S. (2001). Adolescent development. Journal of Cognitive Education and Psychology, 2(1), 55-87.

Steinberg, L. (2014). Age of opportunity: Lessons from the new science of adolescence. Houghton Mifflin Harcourt.

Stevenson, J., \& S. Clegg (2012). "Who cares? Gender dynamics in the valuing of extra-curricular activities in higher education." Gender and Education, 24(1), 41-55.

Stoet, G., \& Geary, D. C. (2013). Sex differences in mathematics and reading achievement are inversely related: Within-and across-nation assessment of 10 years of PISA data.

Taniguchi, H. (2005). The influence of age at degree completion on college wage premiums. Research in Higher Education, 46(8), 861-881.

The Economist (2015). The weaker sex, gender, education and work. The Economist.

Thomas, L. (2012). Building student engagement and belonging in Higher Education at a time of change. Paul Hamlyn Foundation, 100.

Tinto, V. (1997). Colleges as communities: Taking research on student persistence seriously. The review of higher education, 21(2), 167-177.

Torenbeek, M., Suhre, C., Jansen, E., \& Bruinsma, M. (2011). Studentfactoren, curriculumopzet en tijdbesteding als verklaringen. In S. Severiens (Ed.), Studiesuccess in de bachelor. Den Haag.

Twenge, J. M., \& Nolen-Hoeksema, S. (2002). Age, gender, race, socioeconomic status, and birth cohort difference on the children's depression inventory: A meta-analysis. Journal of abnormal psychology, 111(4), 578.

Vaatstra, R., \& De Vries, R. (2007). The effect of the learning environment on competences and training for the workplace according to graduates. Higher Education, 53(3), 335-357.

Allen, J., \& van der Velden, R. K. (Eds.). (2011). The flexible professional in the knowledge society: New challenges for higher education (Vol. 35). Springer Science \& Business Media.

Van Houtte, M. (2004). Why boys achieve less at school than girls: The difference betweenboys' and girls' academic culture. Educational Studies, 30(2), 159-173.

Van Houtte, M., Vanderwegen, P., \& Vermeersch, H. (2014). 'Now I want to do something interesting, something fun'. A mixed-methods study into the determinants of horizontal gender segregation at a Belgian university. AISHE-J: The All Ireland Journal of Teaching and Learning in Higher Education, 6(3).

Vantieghem, W., Vermeersch, H. en Mieke, V. H. (2014). Transcending the gender dichotomy in educational gender gap research: the association between gender identity and academic self-efficacy. Contemporary Educational Psychology, 39, 369-378.

Vereniging Hogescholen (2015). Feiten en cijfers; Afgestudeerden en uitvallers in het hoger beroepsonderwijs. Mei 2015 
Veroude, K., Jolles, J., Croiset, G., \& Krabbendam, A. C. (2013). Sex differences in the neural bases of social appraisals. Social Cognitive and Affective Neuroscience. Published online February 5 th.

Veroude, K., Jolles, J., Croiset, G., \& Krabbendam, A.C. (2013a). Changes in neural mechanisms of cognitive control during the transition from late adolescence to young adulthood. Developmental Cognitive Neuroscience, 5, 63-70.

Veroude, K., Jolles, J., Croiset, G. en Krabbendam, A. C. (2013b). Sex differences in the neural bases of social appraisals. Social Cognitive and Affective Neuroscience. Published online February 5 th.

Veroude, K., Jolles, J., Knežević, M., Vos, C. M. P., Croiset, G. \& Krabbendam, L. (2013) Anterior cingulate activation during cognitive control relates to academic performance in medical students. Trends in Neuroscience and Education, 2(3-4), 100-106.

Vossensteyn, H. (2005). Perceptions of student price-responsiveness. A Behavioural Economics Exploration of the Relationships between Socio-economic Status, Perceptions of Financial Incentives and Student Choice. Enschede: CHEPS/UT.

Vossensteyn, J.J., Cremonini, L., Epping, E., Laudel, G., \& Leisyte, L. (2013): InternationalExperiences with Student Financing: tuition fees and student financial support in perspective. Final Report for the Dutch Ministry of Education, Science and Culture. Enschede: CHEPS.

Voyer, D. (2011). Time limits and gender differences on paper-and-pencil tests of mental rotation: a meta-analysis. Psychonomic bulletin \& review, 18(2), 267-277.

Voyer, D., Voyer, S., \& Bryden, M. P. (1995). Magnitude of sex differences in spatial abilities: a meta-analysis and consideration of critical variables.Psychological bulletin, 117(2), 250.

Vuoksimaa, E., Kaprio, J., Kremen, W. S., Hokkanen, L., Viken, R. J., Tuulio-Henriksson, A., $\&$ Rose, R. J. (2010). Having a male co-twin masculinizes mental rotation performance in females. Psychological science.

Wai,J.,Cacchio,M.,Putallaz,M., \&Makel,M.C.(2010).Sexdifferencesintherighttailofcognitive abilities: A 30year examination. Intelligence, 38(4), 412-423.

Wang, M. T., Eccles, J. S., \& Kenny, S. (2013). Not lack of ability but more choice individual and gender differences in choice of careers in science, technology, engineering, and mathematics. Psychological Science, 24(5), 770-775.

Woelders,L., Bijvank,M.N., \&van Batenburg—Eddes, T. TheyDon'tWaituntilTomorrow, ButDo Their Study Duties Now. In: Wolfensberger, M. V., Drayer, L., \& Volker, J. J. Pursuit of Excellence in a Networked Society: Theoretical and Practical Approaches. Münster: Waxmann Verlag.

Zarrett, N., \& Eccles, J. (2006). The passage to adulthood: Challenges of late adolescence. New directions for youth development, 2006(111), 13-28.

Zijlstra, W. Asper, H., Amrani, A., Tupan-Wenno, M., Crul, M., \& Van Stapele, N. (2013). Generiek is Divers: sturen op studiesucces in een grootstedelijke context. Evaluatie G5 -studiesuccesprogramma's 2008-2011. 


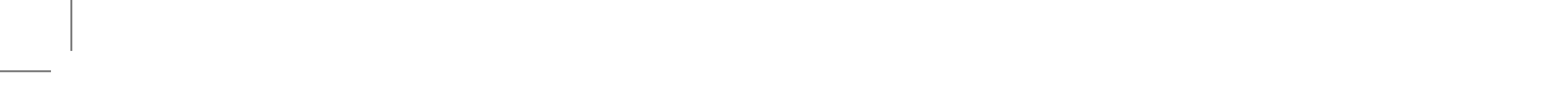

